ana carolina carmona ribeiro

\title{
reconstrução da história e projeto moderno em flávio motta
}

dissertação apresentada ao programa de pós-graduação em artes visuais, área de concentração teoria, ensino e aprendizagem da arte, linha de pesquisa história, crítica e teoria da arte, da escola de comunicações e artes da universidade de são paulo, como exigência parcial para obtenção do título de mestre em artes, sob a orientação do prof. dr. luiz renato martins.

são paulo

2010 
Autorizo a reprodução e divulgação total ou parcial deste trabalho, por qualquer meio convencional ou eletrônico, desde que citada a fonte.

email: accribeiro@usp.br

Ribeiro, Ana Carolina Carmona

Reconstrução da história e projeto moderno em Flávio Motta / Ana Carolina Carmona Ribeiro. -- São Paulo : A. C. C. Ribeiro, 2010.

156 p. : il.

Dissertação (Mestrado) - Programa de Pós-Graduação em Artes Visuais / Escola de Comunicações e Artes / USP.

Orientador: Prof. Dr. Luiz Renato Martins.

Bibliografia

1. História da arquitetura (Crítica) - Brasil 2. Arquitetura moderna - Brasil - Século 20 3. Art nouveau - São Paulo 4. Motta, Flávio Lichtenfels (1923) I. Título.

CDD 21.ed. -720 
Nome RIBEIRO, Ana Carolina Carmona

Título Reconstrução da história e projeto moderno em Flávio Motta

Dissertação apresentada à Escola de Comunicações e Artes da Universidade de São Paulo para obtenção do título de Mestre em Artes Visuais

\section{Aprovado em}

\section{Banca Examinadora}

Prof. Dr. Instituição

Julgamento Assinatura

Prof. Dr. Instituição Julgamento Assinatura

Prof. Dr. Instituição Julgamento Assinatura 



\section{agradecimentos}

Ao orientador Luiz Renato Martins e a todos aqueles que deram sua contribuição para a realização deste trabalho: Ana Clara Gianecchini, Ana Maria Carmona Ribeiro, Ana Luisa Carmona Ribeiro, Carolina Heldt D'Almeida, Carolina Leonelli, Carolina Oukawa, Clarissa Paulillo, Ethel Leon, Flávio Motta, Francisco Alambert, Gabriel Pedrosa, Gabriela Tamari, Gustavo Motta, Helene Afanasieff, Isadora Guerreiro, Israel Luz, Juliana Braga, Julio Katinsky, Kate Saraiva, Lelita Oliveira, Luciano Migliaccio, Luiz Recaman, Maria Cecília Loschiavo dos Santos, Marianna Boghosian, Patrícia Hiraki, Paulo Mendes da Rocha, Pedro Carmona Ribeiro, Rafael Perrone, Rosa Artigas, Rubens Machado, Silvio Dworecki.

Às bibliotecas do Masp e da FAUUSP, e à equipe do LPG da FAUUSP. 

O presente trabalho tem como objeto a investigação da operação de reconstrução da história da arte e arquitetura no Brasil, por meio do trabalho crítico e historiográfico de Flávio Lichtenfels Motta na década de 1950. Partindo da operação de tradicionalização do presente, tal como formulada por Mário de Andrade (1893-1945) ainda na década de 1920, iremos analisar os textos "400 anos de pré-história das artes" (1954), "São Paulo e o art nouveau" (1953), Contribuição ao estudo do art nouveau no Brasil (1957) e "Introduzione al Brasile" (1960) - apontando como neles se delineia a "revisão histórico-crítica" proposta por Motta e quais os seus fundamentos. A leitura de Motta - diferenciando-se do que nas últimas décadas tem-se chamado de trama dominante da historiografia da arquitetura moderna brasileira, chave interpretativa que constrói uma ligação indissolúvel e naturalizada entre o barroco-colonial e as primeiras manifestações do moderno - tem como ponto de partida as insuficiências e limitações do desenvolvimento cultural brasileiro. Chamando a atenção para novos períodos históricos (como a Primeira República) e regiões do país (São Paulo, por exemplo), o autor irá de certa forma atualizar as preocupações de Mário de Andrade, em relação ao significado da tradição e a importância da produção coletiva e sistemática, e em relação às ligações entre arte, trabalho, técnica e indústria. Refletirá criticamente sobre o movimento moderno brasileiro, com a identificação de diferentes tendências e a busca de novos fundamentos para a produção arquitetônica, assim como uma valorização pioneira da obra de Vilanova Artigas. O estudo da "revisão histórico-crítica", assim, traz à tona um elo importante da história intelectual de São Paulo, contribuindo para que, hoje, possamos caminhar em direção a um entendimento mais problematizado da arquitetura moderna brasileira, em suas disjuntivas, contradições e possibilidades.

\section{Palavras-chave}

Arquitetura moderna; Crítica de arquitetura; Flávio Motta; Art nouveau. 



\section{abstract}

The present work intends to investigate the activity of reconstruction of the history of art and architecture in Brazil, by means of Flávio Lichtenfels Motta's critical and historiographical work in the years of 1950. Beginning with the operation of traditionalization of the present, as conceived by Mário de Andrade (1893-1945) in the 1920's, we will analyze the articles "400 anos de pré-história das artes" (1954), "São Paulo e o art nouveau" (1953), Contribuição ao estudo do art nouveau no Brasil (1957) e "Introduzione al Brasile" (1960) - indicating how in such texts the "historical-critical revision" proposed by Motta is laid out and what are its fundamentals. Motta's critical perspective - differentiating itself from what in recent decades has been called the dominating trend in historiography of brazilian modern architecture, which builds an indissociable and naturalized connection between colonial baroque and the initial manifestations of the modern - has as a starting point the shortcomings and limitations of brazilian cultural development. Bringing focus to new historical periods (as the First Republic) and regions of the country (São Paulo, for instance), the author will update Mario de Andrade's concerns, in terms of the meaning of tradition and the importance of systematical and collective production, and in terms of the connections between art, work, technique and industry. In an effort of critical reflection regarding Brazil's modern movement, the author will identify diverse tendencies and search for new fundamentals for the production of architecture, and also establish a pioneering re-apprehension of the work of Vilanova Artigas. The study of "historical-critical revision", in that way, brings to perspective an important link of São Paulo's intellectual history, contributing to a more complex understanding of modern brazilian architecture, in its distinct components, contradictions and possibilities.

\section{Keywords}

Modern architecture; Criticism of architecture; Flávio Motta; Art nouveau. 



\section{lista de imagens}

Capa Vila Penteado (São Paulo), projeto de Carlos Ekman Foto de Cristiano Mascaro | Fonte: PRADO, M. e MACHADO, L. G. Exposição Vila Penteado. São Paulo, FAUUSP/ Secretaria de Cultura, 1976

Figura 1 Igreja N. Sra. do Rosário dos Pretos (Ouro Preto) Foto de Cristiano Mascaro | Fonte: LAGO, Pedro C. [coord.]. O patrimônio construído: as 100 mais belas edificações do Brasil. São Paulo, Capivara, 2002

Figura 2. Monumento às Bandeiras (São Paulo), de Victor Brecheret Fotógrafo não identificado | Fonte: BATISTA, Marta Rossetti. Bandeiras de Brecheret: história de um monumento (1920-1953). São Paulo, Depto. do Patrimônio Histórico, 1985

Figura 3. Edição Especial do IV Centenário da fundação da cidade de São Paulo

Figura 4. Vila Penteado (São Paulo), projeto de Carlos Ekman

Foto de Cristiano Mascaro | Fonte: PRADO, M. e MACHADO, L. G. Exposição Vila Penteado. São Paulo, FAUUSP/ Secretaria de Cultura, 1976

Figura 5. Páginas do artigo "Floreal", de 1953.

Figura 6. Painéis decorativos do hall da Vila Penteado

Fonte: PRADO, M. e MACHADO, L. G. Exposição Vila Penteado. São Paulo, FAUUSPI Secretaria de Cultura, 1976

Figura 7. Vista aérea do Eixo Monumental de Brasília no início da construção Foto de Marcel Gautherot | Fonte: BURGI, S. e TITAN JR. S. [orgs]. Brasília: Marcel Gautherot. São Paulo, Instituto Moreira Salles, 2010

Figura 8. Seqüência de imagens que ilustra o artigo "Introduzione al Brasile" 

1 mário de andrade, lucio costa e a

tradicionalização da arquitetura moderna brasileira

1.1. Lucio Costa

Um passado uno, lusófilo...

... e moderno

1.2. Mário de Andrade

A nacionalidade problematizada...

...e sua ligação com o modernismo

2 flávio motta e a problematização da história

2.1. Lourival Gomes Machado: o trabalho do historiador da arte no Brasil

2.2. Flávio Motta: um percurso por " 400 anos de pré-história das artes"

2.3. Motta e Mário de Andrade: a história problematizada

3 do novo ao moderno: flávio motta e o art nouveau no brasil

3.1. A rejeição ao art nouveau

3.2. O art nouveau por Flávio Motta

Um movimento republicano e paulista

Origem e transição: art nouveau e movimento moderno

Um estilo sem estilo

Ornamento e construção

A arte entre o artesanato e a indústria

Limites do art nouveau

Limites do moderno

3.3. Motta, a revista Habitat e os fundamentos da reconstrução histórica

E cultura

4 a história num impasse: "introduzione al brasile"

4.1. A centralidade da República e de suas manifestações culturais

4.2. Limites e contradições da "revisão histórico-crítica" 



\section{introdução}

O presente trabalho tem como objeto a investigação da operação de (re)construção da história da arte e arquitetura no Brasil, por meio do trabalho crítico e historiográfico de Flávio Lichtenfels Motta (1923) na década de 1950.

No Brasil, a afirmação da arquitetura moderna sempre esteve intimamente associada à reflexão acerca do passado nacional. A posição que Ana Luiza Nobre confere a Lucio Costa (1902-1998) - "ser moderno" como uma espécie de mediação entre "a memória do passado, a experiência do presente e a perspectiva do futuro", posição historicamente necessária que cumpriria o propósito de afirmar a funcionalidade do passado e indicar o conhecimento histórico como condição do devir ${ }^{1}$ - poderia ser estendida a muitas das manifestações do movimento moderno brasileiro, desde o seu "nascimento" no fim da década de 1920 até suas revisões críticas na década de 1950 e início de 1960.

A questão é originalmente formulada por Mário de Andrade (1893-1945), em 1925. Tendo em vista o acomodamento da "sensibilidade nacional" com a "realidade brasileira", o modernista defende a operação de tradicionalização do presente, ou seja, a vivência do passado na atualidade, fazendo dele "um valor agente pesando no mecanismo brasileiro". Diz Mário: "Nós só seremos deveras uma raça o dia em que nos tradicionalizarmos integralmente e só seremos uma Nação quando enriquecermos a humanidade com um contingente original e nacional de cultura"2.

Nessa perspectiva, atualidade e tradição vinculam-se, num âmbito mais geral, ao problema da formação nacional, ou o "propósito construtivo, deliberado, das elites dirigentes e cultivadas, de dotar o país de linhas evolutivas que culminem no funcionamento coerente de um sistema cultural local" ${ }^{3}$. Em seu desenvolvimen-

1 NOBRE, A. L. "Fontes e colunas: em vista do patrimônio de Lucio Costa". In: NOBRE, A. L. et al [orgs]. Um modo de ser moderno: Lucio Costa e a crítica contemporânea. São Paulo, Cosacnaify, 2004, p. 123124.

2 ANDRADE, M. "Assim falou o papa do futurismo", 1925. In: LOPEZ, Telê Porto A.[org]. Mário de Andrade: entrevistas e depoimentos. São Paulo, TA Queiroz, 1983, p. 18.

3 ARANTES, O. "Esquema de Lucio Costa". In: NOBRE, A. L. et al [orgs]. Op. cit., p. 96. 
to, esse problema da formação irá alimentar o que Martins chama de "equação identidade/ modernidade"4, na arquitetura moderna nacional.

Num primeiro momento - que, grosso modo, é aquele das décadas de 1930 e 1940 - a tradicionalização funciona no sentido de legitimar uma arquitetura moderna e brasileira, sendo a relação modernidade-tradição considerada uma especificidade de nosso movimento moderno e mesmo possível fundamento de nossa originalidade. Nesse período, ao mesmo tempo em que nasce e floresce no país a nova arquitetura - com as primeiras manifestações pontuais em São Paulo, e o posterior "surto sensacional" 5 liderado por Lucio Costa e o grupo de arquitetos cariocas reunidos em torno de Le Corbusier (1887-1965) -, no plano da construção histórica e historiográfica afirma-se a centralidade do período colonial e especificamente do barroco. A "verdadeira tradição brasileira", as mais autênticas e originais manifestações da nacionalidade estariam na colônia, expressas em obras como as do Aleijadinho (1738-1814); entre elas e a moderna arquitetura, existiriam fortes laços de continuidade.

Num segundo momento - ao longo da década de 1950, e início dos anos 1960 -, embora o Rio de Janeiro mantenha uma posição de destaque em relação à produção da nova arquitetura, São Paulo - onde, desde meados dos anos 1940, ocorria um grande crescimento demográfico e industrial, e um boom na indústria da construção civil - irá entrar em cena; arquitetos atuantes na cidade, como Rino Levi (1901-1965), Vilanova Artigas (1915-1985) e Lina bo Bardi (1914-1992), tornam-se mais conhecidos.

O projeto da formação nacional se mantém no horizonte de críticos e arquitetos, mas a novidade é que a discussão agora se dá também em torno do desenvolvimento nacional, que tem como pressupostos básicos a industrialização, a ampliação do mercado interno, a reforma agrária, o planejamento. De 1930 a 1950, o Brasil de fato conhece um grande crescimento econômico, que se revela entretanto limitado e contraditório: tanto no plano mais geral da economia, quanto na própria arquitetura moderna, o que se identifica é a "defasagem entre o que é concebido e o que é possível e realizável" ${ }^{6}$. No caso da industrialização, isso sig-

4 MARTINS, C. A. F. "Lucio Costa e Le Corbusier: afinidades eletivas". In: NOBRE, A. L. et al [orgs]. Um modo de ser moderno: Lucio Costa e a crítica contemporânea. São Paulo, Cosacnaify, 2004, p. 71.

5 PEDROSA, M. "Entre a Semana e as Bienais", 1970. In: PEDROSA, M. e AMARAL, A. [org]. Mundo, homem, arte em crise. São Paulo, Perspectiva, 1975, p. 270.

6 Idem. "A arquitetura moderna no Brasil", 1953. In: PEDROSA, M. e AMARAL, A. [org]. Dos murais de Portinari aos espaços de Brasília. São Paulo, Perspectiva, 1953, p. 255-264. 
nifica que as promessas iniciais - de extensão do progresso e de seus benefícios para a maioria da população brasileira - não estavam se cumprindo; e que a arquitetura moderna, apesar de todos os seus compromissos com a transformação social, cada vez mais pareceria com uma ilha, envolta por "favelas, barracos, efervescência da miséria e urbanismo caótico"7. Assim, a operação de tradicionalização do presente adquire um novo sentido e contornos mais problematizados.

É neste segundo momento - foco principal de nosso trabalho - que se insere a figura de Flávio Motta, professor, artista plástico, crítico de arte e arquitetura. Trabalhando no Museu de Arte (MASP) como assistente de Pietro Maria Bardi (1900-1999), a partir do início da década de 1950 Motta começa a configurar o que chama de "revisão histórico-crítica"8 da arte e arquitetura brasileiras.

Essa revisão tem como ponto central a proposição de uma nova abordagem historiográfica, em que as contradições e limitações da história do país são apontadas como relevantes e mesmo essenciais para a consideração do desenvolvimento cultural nacional. Para além do barroco-colonial, o autor chama atenção para a importância de novos períodos históricos (como a Primeira República) e regiões (São Paulo, por exemplo); valoriza o trabalho imigrante e o saber-fazer artesanal das primeiras décadas do século XX; identifica, ainda no início dos anos 1950, o surgimento de uma nova geração de arquitetos em São Paulo e é um dos primeiros críticos a atentar para a produção de Artigas.

A sua reflexão traz uma contribuição crítica original para a arquitetura e a arte brasileiras, ao retomar Mário de Andrade e sugerir importantes pontos de contato entre este e a obra teórica e projetual de Lina e Artigas. O estudo da produção de Motta nos anos 1950, assim, traz à tona um elo importante da história intelectual de São Paulo - apontando para uma via alternativa à chamada "trama dominante" da historiografia da arquitetura moderna brasileira (que identifica um "espírito geral de nossa arquitetura", uno e contínuo, a partir do qual seria possível construir uma ligação direta e indissociável entre passado colonial e arquitetura moderna ${ }^{9}$ ) e contribuindo para que, hoje, possamos caminhar em dire-

7 PEDROSA, M. "A arquitetura moderna no Brasil", 1953. In: PEDROSA, M. e AMARAL, A. [org]. Dos murais de Portinari aos espaços de Brasília. São Paulo, Perspectiva, p. 255-264.

8 Para Motta, a revisão histórica - também chamada de revisão crítica - da história da arte nacional é uma "perspectiva de domínio sobre as nossas tendências (...) e sobre a nossa possibilidade criadora", constituindo-se assim num conceito-chave para o seu trabalho ao longo dos anos 1950 (MOTTA, F. Contribuição ao estudo do art nouveau no Brasil. Tese (cátedra). São Paulo, FAUUSP, 1957, p. 7).

9 MARTINS, C. F. "A constituição da trama narrativa na historiografia da arquitetura moderna brasileira". In: Revista Pós no. especial. São Paulo, FAUUSP, 1994, p. 91-95. 
ção a um entendimento mais problematizado do próprio movimento moderno brasileiro, em suas disjuntivas, contradições e possibilidades.

A pesquisa baseou-se, fundamentalmente, na análise de textos - não apenas aqueles do próprio Flávio Motta, produzidos entre os anos de 1953 e 1960, mas também textos de autores com quem, direta ou indiretamente, Motta dialogou: primeiramente, Mário de Andrade e Lucio Costa, que colocam as bases da discussão da tradicionalização da arquitetura moderna, ainda na década de 1930; em segundo lugar, autores contemporâneos a Motta, como os críticos Lourival Gomes Machado (1917-1967), Luis Martins (1907-1981), o arquiteto Luis Saia (19111975), e, especialmente, Vilanova Artigas e Lina bo Bardi - cujos escritos, ora alimentando sua reflexão, ora se distanciando dela, constituíram importante recurso para que a discussão da tradicionalização do moderno fosse historicamente situada e criticamente entendida.

Essa opção pela análise de textos, embora relativamente limitada - já que não incluiu, dentre os objetos de estudo, projetos e obras arquitetônicas que poderiam enriquecer o trabalho com outras visadas - nos permitiu, em compensação, realizar uma análise detida da produção crítica de Motta. Isso nos parece bastante importante, tendo em vista que sua obra - até hoje pouco conhecida e estudada - revelou-se como uma nova e relevante contribuição para o estudo da arquitetura moderna brasileira, no sentido de que expressa a existência de diferentes tendências dentro do chamado movimento moderno, e demonstra como críticos e arquitetos se posicionaram frente aos problemas e contradições do desenvolvimento capitalista no Brasil.

O trabalho estrutura-se em quatro capítulos, que procuram refazer a trajetória da revisão histórico-crítica de Flávio Motta ao longo da década de 1950, e aprofundar a discussão acerca de seus principais textos produzidos no período. 0 primeiro capítulo expõe o significado da operação de tradicionalização do presente, tal como formulada por Mário de Andrade. Discute como essa operação é trabalhada por Mário e pelo arquiteto Lucio Costa, no decorrer da década de 1930 - aproximando e confrontando a visão dos dois autores em relação à recuperação do passado artístico e arquitetônico nacional, em suas relações com o movimento moderno e a atualidade.

O capítulo seguinte centra-se na análise do texto " 400 anos de pré-história das artes", publicado por Flávio Motta por ocasião do IV Centenário de São Paulo, 
em 1954. Trata da especificidade da visão de Motta naquele contexto, expondo como o autor retoma e desenvolve, durante a década de 1950, o pensamento de Mário de Andrade em relação à tradicionalização do presente - propondo uma problematização da história da arte e arquitetura no Brasil. O capítulo também discute as relações da proposição de Motta com aquelas de outros autores contemporâneos, em especial Lourival Gomes Machado e Lucio Costa.

No terceiro capítulo, são analisados os textos de Motta sobre o art nouveau no Brasil (de 1953 e 1957), nos quais o autor manifesta a intenção de realizar a "revisão histórico-crítica" das manifestações artísticas nacionais. Situando os textos (inclusive, na proximidade de Motta com a revista Habitat, da qual foi diretorgeral em 1953), expondo seu desenvolvimento e destacando o teor inédito de sua perspectiva, o capítulo aprofunda a discussão iniciada no capítulo anterior, apontando os fundamentos da reconstrução histórica proposta: o estabelecimento de novas funções para a arte por meio de sua re-ligação com o artesanato, a indústria e a técnica (daí a revisão do século XIX e das bases da arte moderna, por Motta) e a revisão das relações com a esfera do trabalho e o papel do trabalhador no fazer artístico e arquitetônico.

Finalmente, no quarto capítulo, analisamos o texto "Introduzione al Brasile" uma espécie de panorama geral da arquitetura e das artes brasileiras para o público italiano, publicado na revista Zodiac em 1959-1960 - tomando-o como corolário do processo crítico-reflexivo de reconstrução da história realizado por Motta nos anos anteriores. Ou seja, como uma nova síntese da história da arte brasileira (em relação à de "400 anos..."), na qual ficam mais claramente definidas as expectativas do autor em relação à burguesia, ao papel do artista, do arquiteto e do intelectual. No texto, já é possível estabelecer as primeiras contradições e impasses decorrentes da tentativa do autor de colocar no centro da revisão histórico-crítica a industrialização (e a burguesia como seu agente fundamental). 



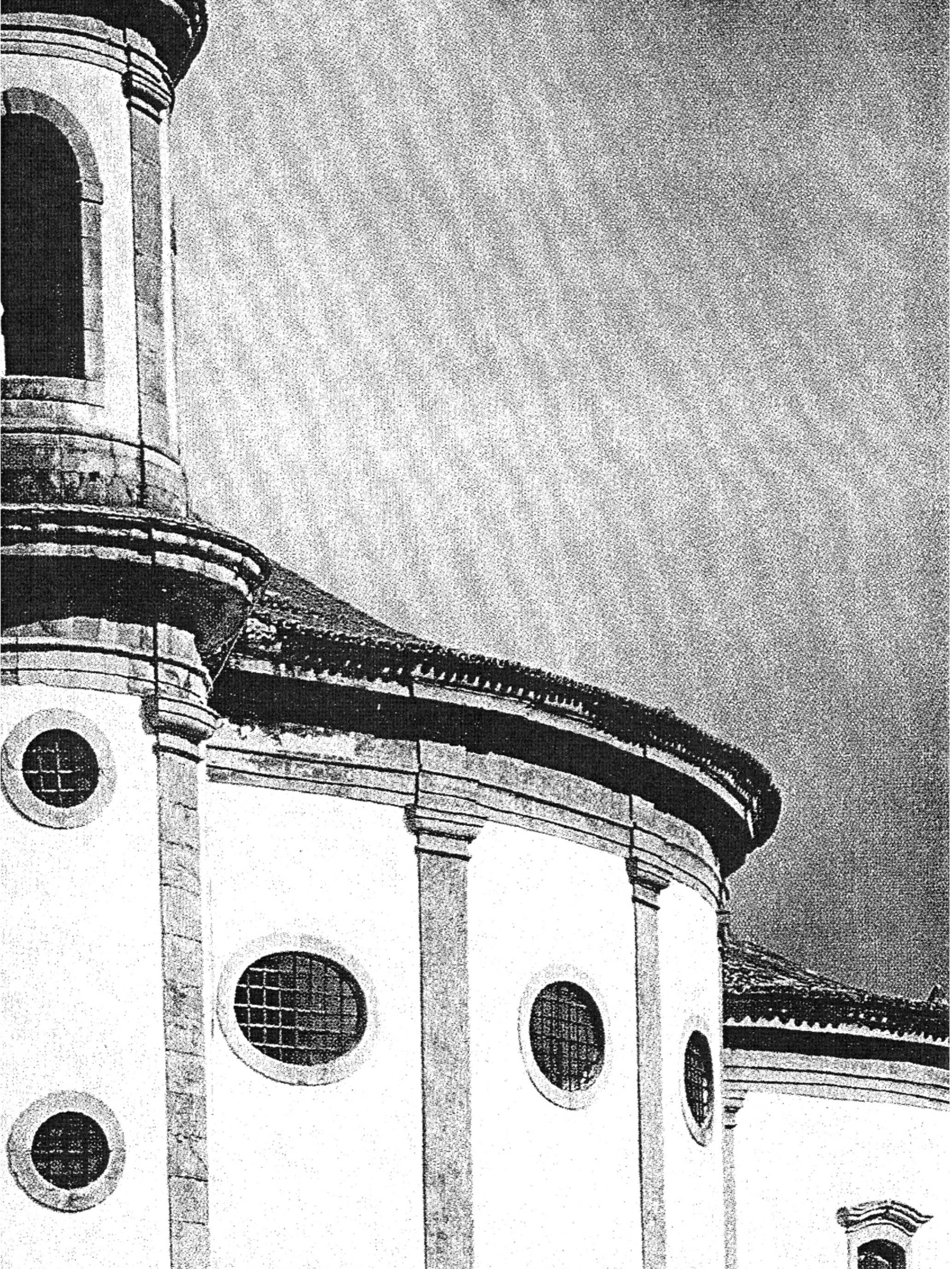


Figura 1 [página anterior]

Igreja N. Sra. do Rosário dos Pretos (Ouro Preto)

por Cristiano Mascaro 


\section{mário de andrade, lucio costa \\ e a tradicionalização da arquitetura moderna brasileira}

Passados apenas três anos da Semana de Arte Moderna de 1922, Mário de Andrade já revisava as posições nela manifestas, as suas e as dos outros artistas. Para ele, terminada a fase de revolta e de "exageros", já era hora dos modernistas voltarem a "se reintegrar na torrente humana", passando da destruição à construção. E de encararem o maior problema atual do Brasil: o acomodamento da sensibilidade nacional com a realidade brasileira - uma "realidade que não é só feita de ambiente físico e dos enxertos de civilização que grelam nele, porém comportando também a nossa função histórica para conosco e social para com a humanidade".

Dizia o modernista: "Nós só seremos deveras uma raça o dia em que nos tradicionalizarmos integralmente e só seremos uma Nação quando enriquecermos a humanidade com um contingente original e nacional de cultura". E, explicitando o que entende por "tradicionalização", noção central para a discussão que estamos a iniciar, esclarece: tradicionalizar seria fazer do passado um "valor agente pesando no mecanismo brasileiro", seria viver o passado na atualidade - o oposto de revivê-lo, tomando-o como "visão desrelacionada e morta"1.

Dessa forma, ainda na década de 1920, é formulado o princípio da ligação, indissolúvel, entre a atualidade (representada, aqui, pelo modernismo) e a tradição, ligação vinculada num âmbito mais geral ao problema da construção ou, como se convencionou chamar, da formação nacional². Pautando a transformação cultu-

1 ANDRADE, M. "Assim falou o papa do futurismo", 1925. In: LOPEZ, Telê Porto A.[org]. Mário de Andrade: entrevistas e depoimentos. São Paulo, TA Queiroz, 1983, p. 18.

2 A idéia de formação guiará o debate intelectual brasileiro ao longo das décadas seguintes, nas mais diversas áreas do conhecimento. Segundo Otilia Arantes, formação é "propósito construtivo, deliberado, das elites dirigentes e cultivadas, de dotar o país de linhas evolutivas que culminem no funcionamento coerente de um sistema cultural local, tendo por modelo e parâmetro crítico a relativa organicidade da vida cultural européia no que concerne à sua capacidade de incidir (e formalizar) no campo de forças constituídas pela sociedade moderna. Supõe portanto o ideal de seriação, concatenação, continuidade, tradição, em contraparte à barafunda de nossa vida mental (...) ou seja, supõe um sistema de referências recíprocas por oposições às manifestações avulsas e isoladas". O período colonial passa a ser momento 
ral pela união entre o "novo Brasil" e o "Brasil original", foram nesses anos que "a vanguarda artística teve como programa o conhecimento e transformação de uma nação que se emaranhava nas relações coloniais onipresentes e nos modelos de progresso industrial a serem seguidos" 3 .

Mais para o final da década, o programa modernista irá se ligar aos primeiros debates em torno da renovação da produção arquitetônica, alimentados tanto pelo movimento neocolonial quanto pelas manifestações inaugurais da nova arquitetura - dentre as quais as casas modernistas de Gregori Warchavchik (1896-1972), os projetos de Flávio de Carvalho (1899-1973) e a primeira visita de Le Corbusier ao Brasil. Mário de Andrade tomará parte ativa nesses debates e estará entre os primeiros a estender a lição modernista à arquitetura, com a preocupação de uma síntese entre "arquitetura nova e tradição local"4. Procurando estabelecer uma linha histórico-evolutiva para a arte brasileira (em oposição à arte luso-brasileira, como veremos), Mário investigará tanto a constituição da personalidade artística nacional como as tentativas de procura e fixação dos elementos de nossa "constância arquitetônica".

Ao longo da década de 1930, a discussão e a produção da arquitetura moderna brasileira desenvolvem-se, transferindo-se o centro dos debates para o Rio de Janeiro - onde o arquiteto Lucio Costa irá assumir uma posição de destaque, numa trajetória profissional bastante conhecida e que se confunde com a do próprio surgimento da nova arquitetura, na capital federal. Nos textos de Costa, a noção de evolução estará sempre presente; visualizando no período colonial a existência de uma "linha" ou de um "espírito geral de nossa arquitetura" ${ }^{5}$, procurará prolongar essa linha até o século $\mathrm{XX}$, inserindo a arquitetura moderna na "evolução que se estava normalmente processando"6.

Esse desenvolvimento, entretanto, só pode ser plenamente compreendido se, além de consideradas as mudanças estruturais pelas quais passava o Brasil nesse período, for dada a devida importância ao horizonte teórico e artístico constituído pelos debates da década anterior. No vínculo entre o modernismo de 22

privilegiado nesse debate, já que a idéia de formação sempre girou em torno da "questão crucial da passagem, moderna por excelência, da colônia à nação" (ARANTES, O. "Esquema de Lucio Costa". In: NOBRE, A. L. et al [orgs]. Um modo de ser moderno: Lucio Costa e a crítica contemporânea. São Paulo, Cosacnaify, 2004, p. 96).

3 RECAMAN, L. Por uma arquitetura, brasileira. São Paulo, FFLCH (Dissertação mestrado), 1996, p. 17.

4 lbid., p. 38.

5 COSTA, L. "O Aleijadinho e a arquitetura tradicional", 1929. In: XAVIER, Alberto [org]. Lucio Costa: sobre arquitetura. Porto Alegre, UniRitter, 2007, p. 14-15.

6 ld. "Documentação necessária", 1937. In: XAVIER, Alberto [org]. Op. cit., p. 91. 
e o nascimento da arquitetura moderna e brasileira, está uma chave importante para as leituras - bastante freqüentes, entre os estudiosos do projeto moderno no Brasil - que procuram aproximar os pensamentos dos pioneiros Mário de Andrade e Lucio Costa em suas respostas à "equação identidade/ modernidade"7.

É justamente na existência dessa relação entre o pensamento dos dois autores, entre o final das décadas de 1920 e 1930, em que pretendemos nos deter neste primeiro capítulo. Pelas aproximações e continuidades de suas elaborações teóricas, e pela identificação das dissonâncias e diferenças, podemos destrinchar o significado da "tradicionalização" do presente formulada por Mário e assumida por Lucio; assim como o seu sentido e modo de operação, no momento de "formação" do próprio modernismo brasileiro.

Além disso, essa continuidade entremeada de diferenças irá ganhar importância se, ampliando a visada, nos remetermos ao desenvolvimento posterior da arquitetura moderna e aos debates em torno dela, em especial em São Paulo nas décadas de 1950 e 1960 - quando se inicia um período de revisão do movimento moderno brasileiro, e seus limites e potencialidades passam a ser discutidos teórica, histórica e projetualmente por críticos como Flávio Motta e arquitetos como Vilanova Artigas e Lina bo Bardi, cujos posicionamentos se mostrarão especialmente relevantes para o presente trabalho.

Por ora, concentraremos nossa análise nos textos produzidos por Mário de Andrade e Lúcio Costa num período restrito que vai de 1928 a 1939; são dez anos que concentram e sintetizam o diálogo desses dois autores (não um diálogo direto, mas sim uma conversa por nós construída, com base em temas e preocupações semelhantes), e o momento formativo da arquitetura moderna brasileira.

Além disso, é um período marcado pela Revolução de 1930. A presidência (em 1937 transformada em ditadura) de Getúlio Vargas (1882-1954) representa a ascensão do capitalismo nacional, suportado pelas forças armadas e pela aliança entre burguesia industrial e setores da classe trabalhadora urbana; a burguesia agro-exportadora perde espaço (embora não tenha de maneira nenhuma sido excluída do jogo político), e inicia-se um processo de mudanças nos mais diversos

7 MARTINS, C. A. F. "Lucio Costa e Le Corbusier: afinidades eletivas". In: NOBRE, A. L. et al [orgs]. Um modo de ser moderno: Lucio Costa e a crítica contemporânea. São Paulo, Cosacnaify, 2004, p. 71.

8 FAUSTO, B. História concisa do Brasil. São Paulo, Edusp, 2006, p. 182. 
setores. Em relação à cultura, as novas condições político-econômicas permitem que as aspirações geradas na década de 1920 se difundam e se "normalizem". Esse alargamento de participação atinge os mais diversos setores, como a educação pública, a vida artística e literária, os estudos históricos e sociais, etc; estabelece-se uma nova correlação entre intelectuais e artistas, de um lado, e a sociedade e o Estado, de outro; em um movimento de radicalização, intelectuais e artistas se engajam na renovação política, religiosa e social ${ }^{9}$.

1928 é ano de grandes polêmicas no meio cultural paulistano, devido à inauguração da casa modernista da rua Santa Cruz, de Warchavchik; nesse ano, Mário escreve dois textos que se complementam: "O Aleijadinho e sua posição nacional" - análise da obra do artista e das condições sociais em que ele se insere, apontando para o momento do surgimento de uma arte propriamente brasileira, em oposição à tradição portuguesa; e "Arquitetura colonial" - reunião de uma série de artigos onde é discutida a validade do neocolonial (visto como possibilidade de "procura e a fixação dos elementos da constância arquitetônica brasileira"), frente à nascente "arquitetura modernista".

Em 1929, Lucio Costa - que já dava os primeiros sinais de ruptura com o movimento neocolonial, do qual era um dos mais destacados membros - também se volta para o Aleijadinho. As restrições que o jovem arquiteto coloca ao célebre artista mineiro nesse momento são marcadas por uma contraposição ao "decorativismo" e pela defesa de um "verdadeiro espírito geral" da arquitetura brasileira. Em setembro de 1930, ainda reconhecido como expoente do estilo neocolonial, Costa será convidado por Francisco Campos (1891-1968), ministro da Educação de Washington Luís ${ }^{10}$, para assumir a direção da Escola Nacional de Belas Artes; trabalhará pela modernização da escola, numa gestão breve e conturbada.

"Razões da nova arquitetura", escrito entre 1933 e 1935", demonstra a consolidação do pensamento de Costa, em relação à arquitetura moderna. $O$ texto pode ser lido como uma espécie de manifesto, com explicação dos princípios da nova arquitetura (tomados de Le Corbusier principalmente) e sua inserção numa linha

9 CANDIDO, A. "A Revolução de 30 e a cultura". In: CANDIDO, A. A Educação pela noite e outros ensaios. São Paulo, Ática, 1987, p. 182.

10 O episódio do convite a Lucio Costa é relatado em detalhes no artigo "Lúcio Costa e a Escola Nacional de Belas Artes" (PINHEIRO, M. L. B. "Lúcio Costa e a Escola Nacional de Belas Artes". Disponível em <www. docomomo.org.br/seminario\%206\%20pdfs/Maria\%20Lucia\%20Bressan\%20Pinheiro.pdf >. Acesso em 22/04/2010).

11 A data deste texto é polêmica, pois o próprio Lucio Costa fornece duas datas diferentes: na edição fac-similar do livro organizado por Xavier, em 1962, e posteriormente revisado por Costa, a data do texto (1930) é corrigida pelo próprio arquiteto: "1933-35". Em Registro de uma vivência, a data é 1934. 
evolutiva que remete às "mais puras tradições mediterrâneas". O período de escritura desse texto coincide com o da elaboração do projeto do Ministério da Educação e Saúde Pública (MESP), por uma equipe de jovens arquitetos liderada por Costa e amparada por Le Corbusier. O projeto, construído entre 1936 e 1945 e inaugurado apenas em 1947, torna-se um marco da arquitetura moderna brasileira - e passa a ser reconhecido como uma espécie de "síntese estética" entre racionalismo corbusiano e características nacionais ${ }^{12}$.

Em 1936, a pedido do ministro Gustavo Capanema, Mário de Andrade (então diretor do Departamento de Cultura de São Paulo) elabora o "Anteprojeto para a criação do Serviço de Patrimônio", onde expõe uma concepção ampla e inclusiva do patrimônio (incluindo categorias como "artes arqueológica e ameríndia", "arte popular", "arte histórica", "arte erudita" e "artes aplicadas") e demonstra a sua preocupação com o folclore.

No ano seguinte, é fundado o Serviço de Patrimônio Histórico e Artístico Nacional (SPHAN) e inaugurada a sua Revista, que vem a se tornar um importante meio de veiculação dos trabalhos realizados pela instituição. Em "Documentação necessária", texto publicado no primeiro número, Lucio Costa aprofunda a investigação das raízes tradicionais da nova arquitetura, dos elementos que a fundamentam e permitem que ela seja inserida na "linha evolutiva" das artes e arquitetura brasileiras - destacando, nessa investigação, o seu caráter popular e a "boa tradição" guardada pelos velhos artesãos e mestres de obra ${ }^{13}$.

Em 1938, após o golpe de Estado que inaugura o Estado Novo, Mário demite-se do Departamento de Cultura, e muda-se para o Rio, onde se tornará professor do recém-criado Instituto de Artes da Universidade do Distrito Federal. É então que escreve o texto-roteiro "Curso de filosofia e história da arte", que se tornará também conhecido pelo titulo de "O artista e o artesão" - em que, preocupado com o que chama de "caoticismo da arte contemporânea", discute o papel do artesanato e da individualidade do artista na realização da obra de arte.

O último texto do roteiro é de 1939; são as "Notas sobre a evolução do mobiliário luso-brasileiro", escritas por Costa já no âmbito de seu trabalho no SPHAN.

12 RECAMAN, L. Por uma arquitetura, brasileira. São Paulo, FFLCH (Dissertação mestrado), 1996, p. 56. 13 Costa trabalhará no SPHAN desde a sua fundação, em 1937, até 1972; o seu envolvimento nesse órgão foi tão longo e profundo que, em texto publicado em Registro de uma vivência, o próprio arquiteto se definirá, em vista da arquitetura moderna brasileira, como o representante da "tradição", ao lado de Oscar Niemeyer ("domínio da plástica, dos espaços e dos vôos estruturais (...) o criador") e João Filgueiras Lima ("o arquiteto onde arte e tecnologia se entrosam - o construtor") (COSTA, L. "JFL-Lelé", 1985. In: COSTA, L. Lucio Costa: registro de uma vivência. São Paulo, Empresa das Artes, 1995, p. 434). 
Nelas, o arquiteto afirma a centralidade da influência portuguesa na produção do mobiliário durante o período colonial, reforçando a sua construção de uma "linha evolutiva" das artes no Brasil.

\subsection{Lucio Costa}

\section{Um passado uno, lusófilo...}

Nos textos escritos entre 1929 e 1939, o passado construído por Lucio Costa é estruturado como coisa una e contínua; como diz Araújo, o seu conceito de identidade é "muito mais fluido, plástico e móvel" 14 do que o de Mário de Andrade. Para o arquiteto, o país "tinha mesmo que ser uma coisa só", territorialmente falando:

E quando já se conhece Bahia, Pernambuco e os outros, e que se observa afora pequenos detalhes próprios a cada região, o espírito, a linha geral, a maneira de fazer é sempre a mesma (...) é aí que a gente vê, mesmo sem saber nada de história, só olhando a sua arquitetura antiga, que o Brasil, apesar da extensão, diferenças locais e outras complicações, tinha que ser mesmo uma coisa só. ${ }^{15}$

A unidade ou continuidade não é apenas geográfica; é também temporal e tipológica. Isso fica claro em "Documentação necessária", em que a arquitetura civil produzida ao longo dos três primeiros séculos ${ }^{16}$ - e em especial a "casa desataviada e pobre" - são consideradas por Costa a mais fértil lição do passado arquitetônico brasileiro. O trabalho de pesquisa a ser feito (pelos homens "do oficio") não poderia se limitar apenas

\footnotetext{
à casa de aparência mais amável da primeira metade do século XIX (...), mas abrangendo também a do século XVIII e mesmo os possíveis vestígios da do XVII, quando, sendo a vida ainda áspera, eram mais marcados os contrastes e, como arquitetura propriamente, ela apresentava interesse maior. E não apara fixar somente as casas grandes de fazenda ou os sobradões de cidade (...) mas as casas menores de (...) aspecto menos formalizado, mais pequeno-burguês (...) e também as pequenas casas térreas, de pouca frente, muito fundo (...) por fim, a casa "mínima" (...) de todas elas a única que ainda continua "viva" em todo o país (...) feitas de "pau" do mato próximo e de terra do chão (...) justamente por isso, por ser coisa legítima da terra, tem para nós, arquitetos, uma significação respeitável e digna. ${ }^{17}$
}

14 ARAÚJO, R. "Nas asas da razão: ética e estética na obra de Lucio Costa". In: NOBRE, A. L. et al (orgs.). Um modo de ser moderno: Lucio Costa e a crítica contemporânea. São Paulo, Cosacnaify, 2004, p. 62. 15 COSTA, L. "O Aleijadinho e a arquitetura tradicional", 1929. In: XAVIER, Alberto [org]. Lucio Costa: sobre arquitetura. Porto Alegre, UniRitter, 2007, p. 15. Grifo nosso.

16 Em suas primeiras elaborações, Costa abarca apenas o período colonial. Posteriormente, a partir do final da década de 1930, passará a considerar o período do Império - principalmente a contribuição do arquiteto Grandjean de Montigny (1776-1850) e de seus discípulos (a "reação acadêmica, liberal e puritana" do neoclássico ao período barroco).

17 COSTA, L. "Documentação necessária", 1937. In: XAVIER, Alberto [org]. Op. cit., p. 88-89. 
Na raiz dessa unidade de caracterização do passado artístico e arquitetônico brasileiro está a existência de uma relação de proximidade e concordância (e não conflito ou distanciamento) entre colônia e metrópole. Recaman, por exemplo, irá falar no "lusitanismo" de Costa, destacando a sua caracterização da nacionalidade e da "personalidade social" brasileiras a partir de um vínculo "quase absoluto" com Portugal ${ }^{18}$. A análise da evolução do mobiliário luso-brasileiro, feita por Costa em 1939, poderia ser estendida para a produção arquitetônica propriamente dita e demonstra bem o papel-chave que, a seus olhos, exercia Portugal:

Tendo o Brasil permanecido como colônia portuguesa até 1822, é natural que nosso mobiliário seja, antes de mais nada, um desdobramento do mobiliário português. Se o material empregado era, isto sim, bem brasileiro, aqueles que o trabalharam foram sempre ou portugueses (...) ou, quando nascidos no Brasil, de ascendência exclusivamente portuguesa, ou então mestiços (...) Quanto ao negro ou índio sem mistura, limitava-se o mais das vezes a reproduzir os móveis do reino e que de qualquer forma se fazia mestre no oficio sob as vistas do português.

Além disso, (...) as lições da missão francesa e a importação direta, durante o século XIX, de certas modas européias, todas as demais influências: a moura, a italiana, a espanhola, a francesa, a inglesa e também a indiana - todas elas nos vieram sempre de segunda mão, através de Portugal. ${ }^{19}$

O modo como a produção artística e arquitetônica importada de Portugal se naturaliza "brasileira" (ou "luso-brasileira") terá sido menos por "inovações próprias" ou "criações locais", do que pela insistência na reprodução de determinados modelos metropolitanos.

E isto, não só porque as modas da corte chegavam aqui com muito atraso e se infiltravam pela vastidão do território da colônia ainda com maior lentidão, mas também porque não havia nenhum interesse particular que estimulasse e justificasse a adoção apressada de novas formas em substituição de outras já consagradas, quando a maneira de viver e todo o quadro social continuavam, não somente inalterados, mas sem perspectivas próximas de alteração. ${ }^{20}$

Dessa tradição luso-brasileira colonial, Lucio Costa irá reivindicar os aspectos mais populares e artesanais ${ }^{21}$; ao invés de valorizar a erudição das escolas arquitetô-

18 RECAMAN, L. Por uma arquitetura, brasileira. São Paulo, FFLCH (Dissertação mestrado), 1996, p. 54. 19 COSTA, L. "Notas sobre a evolução do mobiliário luso-brasileiro", 1939. In: XAVIER, A. [org]. Lucio Costa: sobre arquitetura. Porto Alegre, UniRitter, 2007, p. 97.

20 lbid., p. 98. Grifo nosso.

21 Como lembra Recaman, na mesma época em que Costa propunha essa leitura que valorizava a tradição artesanal e popular portuguesa, outros arquitetos repudiavam-na como "origem desfavorável" e "motivo da má arquitetura praticada no Brasil durante a colônia" - como, por exemplo, Christiano Stockler das Neves (1889-1982), que afirma: "(...) Não devemos portanto aos portugueses influência 
nicas portuguesas ou tratados de arquitetura, irá retomar a "arte do povo", que veio com os portugueses desde os primeiros momentos da descoberta ${ }^{22}$. Isso se reflete não apenas na sua insistência na importância da "arquitetura civil", em oposição à religiosa, como também na busca das características da "Arquitetura portuguesa na colônia" - que teria em sua origem a arquitetura popular e rural de Portugal:

Ora, a arquitetura popular apresenta em Portugal, a nosso ver, interesse maior que a erudita - servindo-nos da expressão usada, na falta de outra, por Mário de Andrade, para distinguir a arte do povo da "sabida". É nas suas aldeias, no aspecto viril das suas construções rurais a um tempo rudes e acolhedoras, que as qualidades da raça se mostram melhor. Sem o ar afetado e por vezes pedante de quando se apura, aí, à vontade, ela se desenvolve naturalmente, adivinhando-se na justeza de proporções e na ausência de make-up, uma saúde plástica perfeita.

Tais características, transferidas - na pessoa dos antigos mestres e pedreiros "incultos" - para a nossa terra, longe de significarem um mau começo, conferiram desde logo, pelo contrário, à Arquitetura Portuguesa na colônia, esse ar despretensioso e puro que ela soube manter, apesar das vicissitudes por que passou, até meados do século XIX. ${ }^{23}$

A célebre figura do "velho portuga" - sempre identificada por Costa com uma tradição construtiva artesanal: "indivíduos que trabalhavam tão bem o jacarandá", "mestres anônimos que proporcionavam tão bem as janelas e portas" 24- seria, assim, a síntese da "boa tradição" da arquitetura brasileira.

Costa não ignora a participação do negro e do índio nessa tradição; a sua mãode-obra contribui, juntamente com fatores como a distância e isolamento da colônia em relação à metrópole e o "acentuado desinteresse por toda a sorte de inovações", para as modificações - dentre elas, o "amolecimento" 25 - pelas quais a "arquitetura portuguesa" irá passar no Brasil:

(...) o índio, habituado a uma economia diferente, que lhe permitia vagares na confecção limpa e cuidada de armas, utensílios e enfeites (...); e o negro, conquanto se

benéfica na evolução da arte entre nós (...) O Brasil sofreu durante muitos séculos a influencia dos jesuítas (...) e ainda a de um elemento pior: o 'mestre de obras', que tanto prejudicou a estética de nossas cidades principais, como se observa nas casas que construíram e que revoltam mesmo aos leigos por tanta falta de gosto" (NEVES, s.d., apud RECAMAN, L. Por uma arquitetura, brasileira. São Paulo, FFLCH (Dissertação de mestrado), 1996, p. 57).

22 RECAMAN, L. Op. cit., p. 57.

23 COSTA, L. "Documentação necessária", 1937. In: XAVIER, Alberto [org]. Lucio Costa: sobre arquitetura. Porto Alegre, UniRitter, 2007, p. 86. Grifos nossos.

24 Idem. "O Aleijadinho e a arquitetura tradicional", 1929. In: XAVIER, Alberto [org]. Op.Cit., p. 16. 25 Noção que Costa toma de empréstimo a Gilberto Freyre (1900-1987). 
tenha revelado com o tempo (...) habilíssimo artista, mostrando mesmo uma certa virtuosidade um tanto "acadêmica" (...) nos trabalhos mais antigos, quando ainda interpreta desajeitadamente a novidade das folhas de acanto, lembra o louro bárbaro e bonitão do norte em seus primeiros contatos com a civilização latina, ou, mais tarde, pretendendo traduzir, com o sotaque ainda áspero e gótico, os motivos grecoromanos renascidos. Em ambos, o mesmo jeito de quem está descobrindo coisa nova e não acabou de compreender direito; sem o vislumbre de maîtrise, mas cheio de intenção plástica e ainda com aquele sentido de revelação que num e noutro depois, com o apuro da técnica, desaparece. ${ }^{26}$

A contribuição negra e índia nas artes e ofícios, entretanto, se dá sempre "sob as vistas do português"; é assim, restrita e determinada por este, não adquirindo características autônomas ou paralelas àquelas da tradição "luso-brasileira". Já os artesãos e artistas mestiços, para Costa, não têm o mesmo papel que lhes confere Mário de Andrade: sua produção não sinaliza instabilidade ou mal-estar ("não havia nenhum interesse particular que estimulasse e justificasse a adoção apressada de novas formas em substituição de outras já consagradas") e não se diferencia daquela dos outros brasileiros de ascendência exclusivamente portuguesa, de forma que todos parecem contribuir unificadamente para o mesmo espírito geral ${ }^{27}$.

\section{... e moderno}

A proposição de recuperação da tradição por Lucio Costa não pode ser separada de sua formação enquanto arquiteto moderno. Para Nobre, na obra de Costa o "ser moderno" seria uma espécie de mediador entre a memória do passado, a experiência do presente e a perspectiva do futuro; apresentado como "histori-

26 COSTA, L. "Documentação necessária", 1937. In: XAVIER, Alberto [org]. Lucio Costa: sobre arquitetura. Porto Alegre, UniRitter, 2007, p. 87. Grifo nosso.

27 É interessante a colocação de Silvana Rubino, ao analisar - em termos temporais, geográficos e tipológicos - a prática do chamado "período heróico" (1937-1968) do SPHAN; ela nos permite perceber um vínculo entre a proposta de "evolução histórica" de Costa e a prática institucionalizada na defesa do patrimônio: "(...) podemos afirmar que no período de criação e consolidação do SPHAN (...) foi eleita uma história vinculada a períodos precisos, lugares e personagens (...) a distância temporal, esse breve profundidade histórica de quatro séculos, não é geradora de alteridade. O SPHAN elegeu um Brasil antepassado que exclui alguns atores contemporâneos ao delimitar claramente de quem 'descendemos'. Não é um discurso da superioridade branca, lusitana e cristã conferido pela detração do outro e sim pela sua exclusão (...) O melhor do passado do SPHAN não traz à luz conflitos ou contrastes. Ao contrário, estabelece uma continuidade" (RUBINO, S. "O mapa do Brasil passado". In: Revista do Patrimônio Histórico e Artístico Nacional, n. 24, 1996, p. 103). Ronaldo Brito, por sua vez, acredita que, sob o aspecto do universo material do trabalho, a obra de Lucio Costa tinha como pressuposto "um futuro muito mais pacífico, um destino mais tranqüilo para a sociedade de massa". E "embora isso não se revestisse de caráter utópico", Brito não deixa de qualificar o arquiteto como "extraordinariamente pequeno-burguês, pois nesse mundo de convívio pacífico, a dimensão do trabalho, que ele obviamente não exclui, surge de uma maneira dócil, quase lúdica" (BRITO, R. "Fluida modernidade". In: NOBRE, A. L. et al [orgs]. Um modo de ser moderno: Lucio Costa e a crítica contemporânea. São Paulo, Cosacnaify, 2004, p. 251). 
camente necessário", esse mediador cumpriria o propósito de afirmar a funcionalidade do passado e indicar o conhecimento histórico como condição do nosso devirir.

Segundo Recaman, Costa, tendo adotado as proposições da arquitetura moderna internacional (a de Le Corbusier especialmente), irá efetuar uma dupla depuração das características da arquitetura tradicional - com vistas à configuração de uma arquitetura não apenas moderna, mas moderna e brasileira: a "depuração social", por meio da qual identifica a "classe" que teria guardado o conhecimento arquitetônico tradicional, e a "depuração estética", que permitirá identificar quais os elementos constitutivos dessa arquitetura - tanto técnica quanto plasticamente ${ }^{29}$.

Seguindo esse esquema interpretativo, veremos que na "depuração social" efetuada por Costa, configura-se um povo constituído por duas principais vertentes: o "velho portuga de 1910", simbolizando a origem portuguesa, e a "casa desataviada e pobre" - a casa mínima ou casa de colono que, com a sua pobreza de meios e simplicidade, representará a arquitetura vernacular legítima da terra brasileira (inclusive literalmente, pois feita de pau-a-pique). Ambas podem ser ligadas à mesma idéia de "razão natural", uma racionalidade que se expressa por meio de um saber construtivo artesanal sem nenhuma relação ou mesmo oposto ao saber convencionalizado da formação erudita ${ }^{30}$; ambas são pontes entre a "boa tradição" do povo e a arquitetura moderna ${ }^{31}$.

28 NOBRE, A. L. "Fontes e colunas: em vista do patrimônio de Lucio Costa". In: NOBRE, A. L. et al [orgs]. Um modo de ser moderno: Lucio Costa e a crítica contemporânea. São Paulo, Cosacnaify, 2004, p. 123124.

29 RECAMAN, L. Por uma arquitetura, brasileira. São Paulo, FFLCH (Dissertação mestrado), 1996, p. 58. 30 Martins faz um paralelo entre essa idéia de "razão natural" em Lucio Costa e a elaboração de Le Corbusier que opõe "casas dos homens" e "casas de arquitetos" (MARTINS, C. A. F. "Lucio Costa e Le Corbusier: afinidades eletivas". In: NOBRE, A. L. et al [orgs]. Op. cit., p. 77). A idéia também não é estranha a Mário de Andrade, que, durante a década de 1930, se mostra admirador do arquiteto franco-suíço, e, na década de 1940, associará, curiosamente, a concepção da "máquina de morar" de Le Corbusier a um sentido "artesanal", destacando o valor humano presente nessa concepção - pois a máquina seria apenas um "meio" para o "morar", que seria o "princípio e finalidade" (ANDRADE, M. "Brazil builds", 1943. In: Vv Aa. Depoimentos 1. São Paulo, CEB/GFAU, 1960, p. 48).

31 Lembremos que, coerente com essa visão de uma tradição popular e anônima, até esse momento a arquitetura moderna para Costa ainda é associada a um valor humano e universal, a uma certa impessoalidade do fazer arquitetônico: "De todas as artes é (...) a arquitetura - em razão do sentido eminentemente utilitário e social que ela tem - a única que, mesmo naqueles períodos de afrouxamento, não se pode permitir - senão de forma muito particular - impulsos individualísticos. Personalidade em tal matéria, se não é propriamente um defeito, deixa, em todo caso, de ser uma recomendação. Preenchidas as exigências de ordem social, técnica e plástica a que, necessariamente, se tem de cingir, as oportunidades de evasão se apresentam bastante restritas" (COSTA, L. "Razões da nova arquitetura", 1933-35. In: XAVIER, Alberto [org]. Lucio Costa: sobre arquitetura. Porto Alegre, UniRitter, 2007, p. 24). A originalidade ou genialidade de certos indivíduos não se oporia a essa universalidade, pelo contrário, contribuiria com 
Já a "depuração estética" é orientada pelos pressupostos da arquitetura moderna, e as características do passado artístico e arquitetônico valorizadas são aquelas coerentes com estes pressupostos: simplicidade, essencialidade, pureza, verdade. Reconhece-se a "boa" tradição tanto por suas qualidades "técnico-funcionais" (como por exemplo a verdade construtiva e a adaptação ao meio) como por suas qualidades "plásticas" ("intenção plástica", "saúde plástica", justeza de proporções, ausência de make-up). Essas características irão orientar o "homem do oficio" em sua escolha do passado a ser recuperado.

O método de fazê-lo é o da realização de uma leitura tipológico-evolutiva da tradição - exemplar em "Documentação necessária" ${ }^{32}$. No texto, a caracterização do povo vem acompanhada da proposta de pesquisa extensiva dos elementos constituintes da arquitetura do passado: sistemas e processos construtivos utilizados, soluções de planta, telhados e alpendres, modelos de esquadrias e ferragens, mobiliário. Não por acaso, alguns destes elementos (como por exemplo as relações entre vedos e vãos e suas conseqüências no aspecto das fachadas), quando inseridos em uma linha evolutiva e justificados funcionalmente, permitiriam entender (e também justificar) formalmente as proposições da arquitetura contemporânea. O texto será ilustrado por esclarecedores croquis que fornecem um complemento fundamental à explicação verbal, pois permitem, mesmo ao leigo, visualizar os vínculos - nesse momento postos como indissolúveis - entre a tradição construtiva nacional e as proposições da nova arquitetura ${ }^{33}$.

\subsection{Mário de Andrade}

\section{A nacionalidade problematizada...}

O quadro social da Colônia, para Mário de Andrade, não tem a estabilidade ou a unidade daquele apresentado por Lucio Costa; em Mário temos um passado menos "fluido" e mais problemático, como se pode ler no texto de 1928 sobre o Aleijadinho.

ela. Os artistas seriam na verdade "antenas", captando a vibração coletiva de um povo ou mesmo de toda a humanidade, nas épocas de transformação, e condensando-a na obra de arte (Ibid., p. 19-20). Esse processo se daria da mesma maneira, em relação à arquitetura: "(...) se, em determinadas épocas, certos arquitetos de gênio revelam-se aos contemporâneos desconcertantemente originais (Brunellesco no começo do século XV, atualmente, Le Corbusier), isto apenas significa que neles se concentram em um dado instante preciso - cristalizando-se de maneira clara e definitiva em suas obras - as possibilidades, até então sem rumo, de uma nova arquitetura" (Ibid., p. 24).

32 Não por acaso, esse texto, publicado no primeiro número da Revista do recém-criado SPHAN, se tornará uma espécie de programa de ação para o órgão de patrimônio, na chamada "fase heróica". Não apenas no sentido da linha a ser seguida (em que a documentação necessária é aquela do período colonial, luso-brasileira etc.), como também no papel-chave relegado aos "homens de oficio" (arquitetos, e não historiadores).

33 Estamos nos referindo à compilação de textos de Lucio Costa organizada por Alberto Xavier e publicada originalmente em 1962 (XAVIER, Alberto [org]. Op. cit., p. 91-93). 
O período do surgimento de uma arte de fato nacional - os anos compreendidos entre 1750-183034, quando em Minas Gerais vive o Aleijadinho - é período "brilhantíssimo, certamente o mais relumeante das artes plásticas brasileiras até agora", e ao mesmo tempo de enorme "malestar", de ausência de qualquer estabilidade financeira; economicamente decadente, é caracterizado pela "inconsciência nacional". O artista mulato que é o maior "engenho artístico" brasileiro deforma, "sem sistematização possível" a tradição luso-colonial de nossa arquitetura - ao mesmo tempo em que a transporta a seu "clímax". Citemos os últimos parágrafos do texto:

O Brasil deu nele o seu maior engenho artístico, eu creio. Uma grande manifestação humana. A função histórica dele é vasta e curiosa. No meio daquele enxame de valores plásticos e musicais do tempo, de muito superior a todos como genialidade, ele coroava uma vida de três séculos coloniais. Era de todos, o único que se poderá dizer nacional, pela originalidade de suas soluções. Era já um produto da terra, e do homem vivendo nela, e era um inconsciente de outras existências melhores de alémmar, um aclimatado, na extensão psicológica do termo. Mas, engenho já nacional, era o maior boato falso da nacionalidade, ao mesmo tempo que caracterizava toda a falsificação da nossa entidade civilizada, feita não de desenvolvimento interno, natural, que vai do centro para a periferia e se torna excêntrica por expansão, mas de importações acomodatícias e irregulares, artificial, vinda do exterior. De fato Antonio Francisco Lisboa profetizava para a nacionalidade um gênio plástico que os Almeidas Juniores posteriores, tão raros! são insuficientes para confirmar.

Por outro lado, ele coroa, como gênio maior, o período em que a entidade brasileira age sob a influência de Portugal. É a solução brasileira da Colônia. É o mestiço e é logicamente a independência. Deforma a coisa lusa, mas não é uma coisa fixa ainda. Vem economicamente atrasado, porque a técnica artística nas Minas foi mais lenta a se desenvolver, que o esplendor econômico feito apenas das sobras dum colonialismo que visava unicamente enriquecer Portugal. Por isso, ele surge quando já não correspondia a nenhuma estabilidade financeira. É um verdadeiro aborto luminoso, como abortos luminosos foram a valorização da borracha e do café, e por muitas partes a industrialização de São Paulo. ${ }^{35}$

34 Para Caio Prado Júnior (1907-1990), é justamente o início do século XIX que "marca uma etapa decisiva em nossa evolução e inicia em todos os terrenos, social, político e econômico, uma fase nova (...) Para o historiador, bem como para qualquer um que procure compreender o Brasil, inclusive o de nossos dias, o momento é decisivo. O seu interesse decorre sobretudo de duas circunstancias: de um lado, ele nos fornece, em balanço final, a obra realizada por três séculos de colonização e nos apresenta tudo o que nela se encontra de mais característico e fundamental, eliminando do quadro ou, pelo menos, fazendo passar ao segundo plano, o acidental e intercorrente daqueles trezentos anos de história. É uma síntese deles. Doutro lado, constitui uma chave, e chave preciosa e insubstituível, para se acompanhar e interpretar o processo histórico posterior e resultante dele, que é o Brasil de hoje. Nele se contem o passado que nos fez; alcança-se aí o instante em que os elementos constitutivos de nossa nacionalidade - instituições fundamentais e energias - organizados e acumulados desde o início da colonização, desabrocham e se completam. Entra-se então na fase propriamente do Brasil contemporâneo, erigido sobre aquela base" (PRADO JR, C. A formação do Brasil contemporâneo. São Paulo, Brasiliense, 2008, p. 9).

35 ANDRADE, M. "O Aleijadinho e sua posição nacional", 1928. In: Depoimentos 2. São Paulo, CEB/ GFAU, 1966, p. 25-26. Grifos nossos. 
Como se vê, esta construção difere da de Lucio Costa, já que, nela, é a diferença em relação à metrópole, a "deformação da coisa lusa" que configura o nacional, que dá à arte brasileira a sua especificidade ou particularidade. E, além disso, mesmo contando com o "gênio plástico" do Aleijadinho, essa nacionalidade está longe de ser plenamente resolvida ou "verdadeira" - já não é feita de desenvolvimento interno, natural; pelo contrário, é fruto também de "importações acomodatícias e irregulares".

Essa diferenciação entre a produção portuguesa no Brasil e a produção brasileira propriamente dita terá influência direta na caracterização do popular feita por Mário de Andrade. A arquitetura brasileira, no período colonial, passa a reinterpretar os elementos fornecidos pela tradição européia, até que "tais elementos deixam de ser acrescentados a uma base, e passam a estruturá-la formalmente, guiados pelas características sociais e psico-sociais de um povo que surgia" 36; essa passagem pode ser vista na "arquitetura já brasileira" de Antonio Francisco Lisboa:

O Aleijadinho, surgindo da lição de Pedro Gomes Chaves ${ }^{37}$, vem generalizar a maneira deste, criando ao mesmo tempo um tipo de igreja que é a única solução original que jamais inventou a arquitetura brasileira. E o que tenho por absolutamente genial nessa invenção é que ela contém algumas das constâncias mais intimas, mais arraigadas e mais étnicas da psicologia nacional, é um protótipo de religiosidade brasileira. Esse tipo de igreja, fixado imortalmente nas duas São Francisco de Ouro Preto e São João Del Rei, não corresponde apenas ao gosto do tempo, refletindo as bases portuguesas da Colônia, como já se distingue das soluções barrocas lusocoloniais, por uma tal ou qual denguice, por uma graça mais sensual e encantadora, por uma "delicadeza" tão suave, eminentemente brasileira. É certo que elas não possuem majestade (...) mas a majestade não faz parte do brasileiro, embora faça parte comum da nossa paisagem. Carece, no entanto, compreender que o sublime não implica exatamente majestade. Não é preciso ser ingente para ser sublime. As igrejas do Aleijadinho (...) são dum sublime pequenino, dum equilíbrio, duma pureza tão bem arranjadinha e sossegada (...) São barrocas, não tem dúvida, mas a sua lógica e equilíbrio de solução é tão perfeita, que o jesuitismo enfeitador desaparece, o enfeite se aplica com uma naturalidade tamanha; que si o estilo é barroco, o sentimento é renascente. ${ }^{38}$

36 RECAMAN, L. Por uma arquitetura, brasileira. São Paulo, FFLCH (Dissertação de mestrado), 1996, p. 25-26.

37 Engenheiro-militar português responsável pelo projeto de igrejas como a N. Sra do Pilar de Ouro Preto (1720). Além de aplicar o "processo das fachadas em planos irregulares, às vezes curvilíneos" - característica desenvolvida de modo equilibrado e "muitíssimo mais gracioso" pelo seu "imitador" Aleijadinho -, a obra do engenheiro reinol traz também o uso de pesados "frontões triangulares" (que são uma "deselegantização", "com toneladas de bruteza", dos frontões das igrejas coloniais nordestinas) (ANDRADE, M. Op. cit., p. 21).

38 ANDRADE, M. "O Aleijadinho e sua posição nacional", 1928. In: Depoimentos 2. São Paulo, CEB/ GFAU, 1966, p. 21-22. 
A figura do "mulato" - que surge como o verdadeiro representante da "raça brasileira", nem português, nem africano - também contribui para a caracterização desse "povo que surgia". No texto sobre o Aleijadinho, não apenas o mineiro, mas vários outros artistas mulatos - Caldas Barbosa, Mestre Valentim, Leandro Joaquim, Padre Nunes Garcia, Joaquim Manuel, todos eles ligados à música ou às artes plásticas - são destacados por Mário como os responsáveis pelo "surto coletivo da racialidade brasileira", todos eles deformadores "sem sistematização possível" da lição ultramarina.

A caracterização da raça, nesse caso, é posta claramente em relação com uma identificação de classe social. Os mulatos, na colônia, são os "desclassificados", classe servil, porém livre:

Os mulatos não eram nem milhores nem piores que brancos portugueses ou negros africanos. O que eles estavam era numa situação particular, desclassificados por não terem raça mais. Não eram negros sob o bacalhau escravocrata, nem brancos mandões e donos. Livres, dotados duma liberdade muito vazia, que não tinha nenhuma espécie de educação, nem meios para se ocupar permanentemente. Não eram escravos mais, não chegavam a ser proletariado, nem nada (...) Porque carece lembrar principalmente dessa verdade étnica: os mulatos eram então desgraçados. Raças aqui tinham os portugueses e negros. Sob o ponto de vista social os negros formavam uma raça apenas. Raça e classe se confundiam dentro dos interesses da Colônia. ${ }^{39}$

Além desse papel ativo conferido aos mulatos enquanto representantes legítimos da "raça brasileira", podemos também destacar a concepção ampla e inclusiva da arte nacional e de suas origens, exposta por Mário em seu "Anteprojeto para o Serviço de Patrimônio" de 1936: nele, ao lado das categorias de "arte histórica", "arte erudita" e "artes aplicadas"40, aparecem as "artes arqueológica e ameríndia" - manifestações "que interessem à Arqueologia" - e a "arte popular" - manifestações "que interessem à Etnografia"41. A proposta era a de que fossem pesquisados e preservados objetos, monumentos, paisagens e folclore (música, histórias, receitas, danças, etc.) desses povos; uma proposta que poderia ser associada a uma espécie de resistência ou valorização da cultura não dominante - e, na discussão que estamos fazendo aqui, não portuguesa.

39 ANDRADE, M. "O Aleijadinho e sua posição nacional", 1928. In: Depoimentos 2. São Paulo, CEB/ GFAU, 1966, p. 15-16.

40 Voltaremos a discutir a importância dessas categorias - em especial a da "arte histórica" e a das "artes aplicadas" - nos próximos capítulos.

41 ANDRADE, M. "Anteprojeto de Criação do Serviço do Patrimônio Artístico Nacional", 1936. In: ANDRADE, M. Cartas de trabalho: correspondência com Rodrigo Mello Franco de Andrade (1936-1945). Rio de Janeiro, SPHAN/ Pró-memória, 1981, p. 40-41. 


\section{...e sua ligação com o modernismo}

É interessante lembrar que o folclore, associado ao caráter étnico ou às "fatalidades raciais" de um povo, irá, na concepção de Mário de Andrade, ser relacionado justamente ao "aspecto social do anonimato da casa modernista". Discutindo a nova arquitetura em 1928, é a "ausência do indivíduo" - sem prejuízo da "presença do ser humano" - que o autor irá destacar como a sua maior qualidade:

Esse aspecto social do anonimato da casa modernista, eu acho bem comovente. Não me basta verificar que a arquitetura modernista se libertando do caráter étnico como nenhuma outra das belas-artes, é a mais moderna e a mais humanamente exata das orientações de agora. Além dessa libertação dos tiques, preconceitos e fatalidades raciais a arquitetura modernista coincide com a manifestação folclórica. Isso que me comove. É interessantíssimo constatar que se as artes à medida que foram evoluindo e se refinando, se afastaram da mais primária, mais fatal das manifestações artísticas, a arte folclórica, a arquitetura modernista que é socialmente falando a mais adiantada das manifestações eruditas da arte, voltou de novo a se confundir com a essência fundamental do folclore: a presença do ser humano com abstenção total da individualidade. ${ }^{42}$

A "individualidade" (ou "personalidade") nas artes é um problema com o qual o autor irá se debater persistentemente, e é central para o seu entendimento acerca da arquitetura (não apenas moderna); ligada a esse problema é que se coloca a discussão do artesanato.

Nesse mesmo texto em que destaca o anonimato da nova arquitetura, Mário irá colocar como condição certa de seu desenvolvimento (ou seja, de sua passagem de "tendência" a solução generalizadamente difundida) a apresentação futura de "fisionomias étnicas e individuais":

As idéias, as fórmulas, as soluções iniciais [da arquitetura modernista] se expandiram com facilidade e como estão ainda na infância, apresentam (...) mais o aspecto da explicação e prova duma teoria que aquela fatalidade de expressão, aquele exabrupto de invenção, que formam o próprio mecanismo da criação artística. Vem daí o caráter anônimo que as soluções modernistas de grandes ou pequenos edifícios apresentam até agora. Dão obras de combate, são obras teóricas, mas o dia em que o estilo se normalizar e o sentimento arquitetônico moderno se tornar inconsciente em nós, as criações nascidas da invenção na certa que irão refletindo cada vez mais o individuo e necessariamente a raça dele (...) A arquitetura modernista, a meu ver, não permanecerá nem no anonimato nem no internacionalismo em que está agora. Se se normalizar ela virá, fatalmente, a se distinguir em frações étnicas e a se depreciar em função do individuo. Se assim é, nada mais justo que a procura e a fixação dos elementos da constância arquitetônica brasileira. É com eles que, dentro da arquitetura moderna, o Brasil dará a contribuição que lhe compete dar. ${ }^{43}$

42 ANDRADE, M. "Arquitetura colonial", 1928. In: Arte em Revista 4, ago 1980, p. 13. Grifo nosso. $43 \mathrm{lbid} .$, p. 13-14. Grifos nossos. 
Essa associação entre personalidade (ou individualidade) e nacionalidade (ou "racialidade") aparece também no texto sobre o Aleijadinho, que, dentre os vários artistas de seu tempo, Mário considera "o único que se poderá dizer nacional, pela originalidade de suas soluções" ${ }^{44}$. A genialidade, característica individual do artista, é a capacidade que este tem de expressar de forma original as constâncias da nacionalidade (presentes no folclore ou na tradição popular, por exemplo) lembremos do trecho já citado onde o autor descreve o seu processo criativo: artista que generaliza a maneira portuguesa de construir e, ao mesmo tempo, cria uma solução original; essa solução é também "genial", pois, trabalhando as "constâncias mais íntimas, mais arraigadas e mais étnicas da psicologia nacional", passa a funcionar como "protótipo" da religiosidade brasileira. Concluindo: para Mário, o gênio é aquele capaz de sintetizar em sua obra as características de um povo, dando-lhes uma característica original que posteriormente voltará a se normalizar, o "protótipo" tornando-se "tipo" ou solução universalizada45.

Na década de 1930, o problema da "individualidade" nas artes parece não apenas se manter, mas se aprofundar. Em vista da situação da produção artística contemporânea - em que a personalidade (e a vaidade dos artistas, "orgulhosos afirmadores de si mesmos") parece, segundo Mário, ter tomado o lugar da obra (esta sim a verdadeira finalidade da arte) - o autor irá propor aos seus alunos do curso de filosofia e história da arte uma reflexão sobre "a técnica de fazer obras de arte". Nessa "técnica", inclui três manifestações diferentes: o artesanato, a virtuosidade, e a "solução pessoal do artista". A virtuosidade, de grande utilidade para o artista, seria "o conhecimento e prática das diversas técnicas históricas da arte", ou "o conhecimento da técnica tradicional". Mas o centro do debate, mesmo, se dará na discussão da relação entre "artesanato" e "solução pessoal", que poderia redefinir os rumos da arte contemporânea.

$\mathrm{O}$ artesanato é definido como o aprendizado do material com que se faz a obra de arte, "o mais útil ensinamento, o que é mais prático e mais necessário" ${ }^{46}$. 0 artista verdadeiro é obrigatoriamente também artesão, conhecendo os segredos, os caprichos, as exigências do material que vai mover.

44 ANDRADE, M. "O Aleijadinho e sua posição nacional", 1928. In: Depoimentos 2. São Paulo, CEB/ GFAU, 1966, p. 25.

45 Notar aqui o paralelo com a definição que Costa, em 1933-35, faz do "gênio" enquanto alguém que "concentra" as possibilidades, até então sem rumo, de uma nova arquitetura (Cf. nota 31).

46 ANDRADE, M. "Curso de filosofia e história da arte", 1938. In: Depoimentos 2. São Paulo, CEB/GFAU, 1966, p. 31. 
Já a "solução pessoal" seria inerente a cada individuo, parte do "talento" nato do artista, a parte da técnica que objetivaria "a verdade interior do artista", obedecendo "a segredos, caprichos e imperativos do ser subjetivo, em tudo o que ele é, como individuo e como ser social" 47. "Inensinável", Mário irá discutir se a solução pessoal seria também "imprescindível". Toma primeiro o exemplo da arquitetura...

\begin{abstract}
A arquitetura é de tal forma regida pelo principio de utilidade, de tal forma ela é condicionada às exigências da engenharia e à prática da vida, que um dos problemas bem discutidos e nebulosos da estética é resolver se a arquitetura é realmente uma das belas-artes, ou se entra para o conjunto das artes aplicadas. Ora a arquitetura, enquanto boa arquitetura, é uma arte que se esquiva muitíssimo à técnica pessoal. Se vemos, por exemplo, o arquiteto Garnier tem um gesto genial de técnica individual resolvendo o problema do teatro (...) logo esta solução se tradicionaliza, é numerosamente usada, e de beleza se transforma em verdade, todos podendo se utilizar dela sem acusação de plágio. (...) na verdade se poderia afirmar, embora um pouco tiranicamente, que, em arquitetura, a criação de uma técnica pessoal bem acusada só serve para criar obras de extravagantes. É o caso da torre Eiffel, em Paris (...) uma extravagância arrojada, muito própria da exposição universal. É, também, o caso, muito menos defensável ainda (pois não se trata de uma experiência comprovatória de uma técnica) do arquiteto catalão Antonio Gaudít8 (...). Não nego a seriedade, a honestidade deste artista, mas, por mais que o respeite, sou obrigado a ver na sua obra de arquitetura menos arquitetura que o desapoderado espírito separatista da Catalunha. A sua igreja da Sagrada Família, em Barcelona, é bem mais do que um pesadelo sentimental e pouco menos que um horror artístico. ${ }^{49}$
\end{abstract}

... para depois contrapor à essa leitura outros argumentos (de "ordem psicológica" e "histórica") que mostrariam ser imprescindível a "técnica pessoal" - como a presença constante de "pormenores pessoais da fatura" (mesmo nas obras aparentemente mais impessoais), e o fato do artista historicamente passar a se reconhecer como individuo.

O autor parece estar numa encruzilhada - pois se defende o artesanato como indispensável ("todo artista tem de ser ao mesmo tempo artesão (...) se perscrutarmos a existência de qualquer grande pintor, escultor, desenhista ou músico,

47 ANDRADE, M. "Curso de filosofia e história da arte", 1938. In: Depoimentos 2. São Paulo, CEB/GFAU, 1966 , p. 30-31

48 Vale notar que o "horror artístico" de Gaudi (1852-1926), ao menos no que se refere às suas pesquisas técnico-construtivas, foi posteriormente "tradicionalizado". Hoje, é sabido que seus projetos contém uma grande variedade de soluções estruturais, por detrás das quais há um trabalho minucioso de pesquisa; o que à primeira vista parece ser apenas uma extravagância formal, pode também ser uma solução estrutural original. As soluções exploradas pelo catalão - como o uso das curvas catenárias, por exemplo - foram aproveitadas e até certo ponto generalizadas por arquitetos tão diferentes como Eero Saarinen (1910-1961), Eladio Dieste (1917-2000) e Álvaro Siza (1933).

49 ANDRADE, M. Op. cit., p. 32-33. 
encontramos sempre, por detrás do artista, o artesão") -, acaba por reconhecer, apesar dos exemplos em contrário, que a "solução pessoal" teria historicamente se tornado necessária à arte, como exigência do "espírito do tempo".

Chega então à noção de "atitude estética": um "justo equilíbrio entre a arte e o social, entre o artista e a sociedade"; a técnica como fruto de uma relação onde as exigências da matéria condicionam o espírito; ou, em outras palavras, o artesanato como exigência material, mas também social e humana, a guiar a "verdade interior" do indivíduo-artista. Prefigura o que Wisnik, mais tarde, irá definir como uma "moral do fazer técnico" 50 .

Assim, para Mário, o artesanato parece ser uma espécie de "baliza" para o artista (ou para o "gênio"), que dá à sua "técnica pessoal" a objetivação dos "caracteres e exigências humanos, individuais e sociais, do artefazer". Presente em todas as épocas históricas, na atualidade o papel do artesanato ganharia importância por lembrar, no "caoticismo" da arte contemporânea e na "estreiteza sem ar da estética experimental", que o importante é a obra e não o artista.

Entretanto, nos parece que a proposta do autor não é a de um "retorno" ao artesanato enquanto modo de produção ${ }^{51}$ : isso seria rodar para trás a roda da história, já que a própria individualidade (ou técnica pessoal) do artista seria um produto histórico, fato dado, mas que precisaria ser re-direcionado rumo à uma forma nova, superior. Os exemplos utilizados no próprio texto, assim como outras referências ao artesanal na arte ${ }^{52}$, mostram bem que a obra de arte, em Mário de Andrade, não pode ser resumida ao artesanato, embora este seja imprescindível a ela, enquanto conhecimento íntimo da técnica.

\footnotetext{
50 WISNIK, G. "A arquitetura lendo a cultura". In: NOBRE, A. L. et al [orgs]. Um modo de ser moderno: Lucio Costa e a crítica contemporânea. São Paulo, Cosacnaify, 2004, p. 36.

51 Wisnik, ao analisar comparativamente o pensamento de Lucio Costa e Mário de Andrade, dá bastante destaque a essa discussão, lendo a "atitude estética" de Mário como uma proposta de "retorno do artista, romântico, vaidoso e egocêntrico, à condição de mero artesão" (Ibid., p. 35-36).

52 Referimo-nos aqui ao artigo "Brazil Builds", publicado em 1943 por ocasião da exposição de mesmo nome, em São Paulo. Nele, Mário elogia a obra arquitetônica de Lucio Costa, pela sua "força de artesanato (...) de princípio, da razão e principalmente de equilíbrio, de não-experimentalismo esbanjador de tempo e dinheiro" - o que Mário admira em Costa são seus projetos, que teriam o artesanato como princípio. Estendendo a nossa análise, talvez possamos afirmar que, se este fosse o caminho normalizado na arquitetura moderna, o artesanato como princípio permitiria, por exemplo, a utilização de elementos "tradicionalizados" (concebidos a partir do artesanato ou da tradição) porém produzidos industrialmente. Um outro exemplo de como, em Mário de Andrade, o artesanato se relaciona à produção artística contemporânea, é seu entendimento da "máquina de morar" de Le Corbusier como uma "definição artesanal" (Cf. nota 29).
} 
A partir do que expusemos, é possível apontar o que, a nosso ver, constitui a diferença fundamental entre o pensamento de Lucio Costa e o de Mário de Andrade, no que toca à problemática das relações entre história e movimento moderno: são duas formas diferentes - que até certo ponto podem ser contrapostas - de interpretação do passado e da tradição, com conseqüências também diversas em sua ligação com a atualidade.

Lucio Costa prioriza a construção de um modelo, uma história de certa forma idealizada; faz um corte "sincrônico" 53 - com a união de diferentes espaços, tempos e tipologias sob um mesmo "espírito geral", que aparece guiando uma evolução pouco conflituosa (inclusive no que se refere à relação com a metrópole, às relações entre as classes, raças etc). Esse modelo, cujas características principais são definidas de acordo com os pressupostos da arquitetura moderna, tem como finalidade a inserção dessa mesma arquitetura numa grande continuidade histórica, justificando-a e caracterizando-a como moderna e brasileira.

Mário de Andrade propõe uma problematização da história; ao procurar o surgimento de uma arquitetura nacional, diferente da arquitetura portuguesa feita no Brasil, irá se deparar com uma evolução descontínua, contraditória e conflituosa. Na impossibilidade de formulação de um modelo ou do estabelecimento de um sistema para a arquitetura tradicional, apontará os impedimentos à plena realização da nacionalidade - seja nas artes e arquitetura, seja econômica e politicamente ${ }^{54}$ - e a persistência destes impedimentos na atualidade ${ }^{55}$.

Há, é claro, importantes pontos de ligação entre os dois autores, na década de 1930 - principalmente no que se refere à centralidade do período colonial para o estabelecimento de uma tradição nacional, momento de formação, que tem "caráter mítico e genealógico; um tempo cíclico onde o reencontro com a origem se prenuncia no futuro"56. Guardadas as devidas diferenças, há também outras aproximações a serem apontadas, como a dimensão popular e artesanal dessa tradição, por exemplo. Mas esses dois pensamentos tendem a se separar ao lon-

53 RECAMAN, L. Por uma arquitetura, brasileira. São Paulo, FFLCH (Dissertação mestrado), 1996, p. 54. 54 A imagem do "aborto luminoso" - válida igualmente para o Aleijadinho, para os ciclos da borracha e do café, e para a industrialização de São Paulo - é o melhor exemplo de como o passado nacional é problematizado por Mário, e como essa problematização refere-se a problemas estruturais da formação nacional

55 O próprio fato de Mário, em 1928, ainda estar à procura do movimento ou artista que pudesse oferecer à arquitetura modernista os "elementos da constância arquitetônica brasileira", mostra bem como para este autor não tinha sido possível construir um passado modelar que fornecesse, formalmente falando, as bases para uma arquitetura nacional.

56 RECAMAN, L. Por uma arquitetura, brasileira. São Paulo, FFLCH (Dissertação mestrado), 1996, p. 63. 
go da próxima década, quando a modernização capitalista mostrar-se-á incapaz de cumprir as promessas de melhoria nas condições de vida da maioria da população. A arquitetura moderna desenvolve-se como "ilha" em meio a um mar de favelas, barracos, efervescência da miséria e urbanismo caótico - e a "defasagem entre o que é concebido e o que é possível e realizável" ${ }^{57}$, impulsiona a reflexão acerca das perspectivas da arquitetura moderna brasileira.

Costa, a partir da década de 1940, irá cada vez mais assumir a defesa da "intenção plástica". Embora as suas elaborações teóricas coloquem a plástica como indissociável das outras exigências - funcionais, técnicas, sociais - da arquitetura ${ }^{58}$, nessa definição de rumos, a universalidade e a impessoalidade (anteriormente ligadas ao popular e à tradição artesanal) darão lugar à predominância da figura do "gênio". A "depuração" do passado é tanta que até mesmo a leitura tipológico-evolutiva (presente em "Documentação necessária", como apontamos) é deixada de lado, enquanto discurso ou elaboração teórica. Mais do que "uns tantos recursos superficiais peculiares à nossa tradição", o que daria o caráter local à arquitetura moderna brasileira seria a "personalidade nacional" ou o "gênio artístico nativo" - do qual o Aleijadinho e Oscar Niemeyer (1907) seriam os meIhores exemplos ${ }^{59}$. Wisnik aponta uma "mudança clara de perspectiva" na obra de Costa, nessa época: a figura de Niemeyer adquire papel de destaque e, da busca pela tradição, Costa passa a valorizar a exploração radical da linguagem (a partir da técnica nova) e a defender a legitimidade da "intenção plástica"60.

57 PEDROSA, M. "A arquitetura moderna no Brasil", 1953. In: AMARAL, A. [org]. Dos murais de Portinari aos espaços de Brasilia. São Paulo, Perspectiva, 1981, p. 255-264.

58 Em "Razões da nova arquitetura", Costa destacará o "valor plástico" da nova arquitetura, considerando-o ao mesmo tempo "rigorosamente e utilitário" e próximo da "arte pura" (COSTA, 1933-35, p. 30). Em "Considerações sobre arte contemporânea", da década de 1950, essa colocação ganhará uma forma mais elaborada e sintética, com a proposta de uma "arte pela arte como função social" (COSTA, L. "Considerações sobre arte contemporânea", 1952. In: XAVIER, Alberto [org]. Lucio Costa: sobre arquitetura. Porto Alegre, UniRitter, 2007, p. 216).

59 COSTA, L. "Depoimento de um arquiteto carioca", 1951. In: XAVIER, Alberto [org]. Op. cit., p. 197. 60 WISNIK, G. "A arquitetura lendo a cultura". In: NOBRE, A. L. et al [orgs]. Um modo de ser moderno: Lucio Costa e a crítica contemporânea. São Paulo, Cosacnaify, 2004, p. 38. Além de Wisnik, diversos outros autores - das mais diversas tendências - apontam a existência de dois caminhos contidos na obra (escrita e construída) de Lucio Costa, entre os quais o arquiteto "oscilaria" e que explicariam, talvez, a inflexão ocorrida a partir de fins da década de 1940. Veja-se, por exemplo, a colocação de Venâncio Filho, para quem o "programa" de Costa, de recuperação dos elementos tradicionais da arquitetura, teria se esgotado, dando lugar à defesa do "gênio" de Niemeyer - que é vista por esse autor como uma "abdicação", da parte de Costa, da constituição de um sistema para a arquitetura brasileira: "apostando em Niemeyer, Lucio como que encerra a sua proposta arquitetônica moderna brasileira, abdica de um sistema. Se fosse possível simplificar a alternativa, seria como optar afinal por termos um grande arquiteto mundial em prejuízo de uma continuidade arquitetônica articulada. (...) Um sistema provisório (...) foi talvez o que LC realizou" (VENANCIO FILHO, P. "Considerações sobre Lucio Costa". In: NOBRE, A. L. et al [orgs]. Um modo de ser moderno: Lucio Costa e a crítica contemporânea. São Paulo, Cosacnaify, 2004, p. p. 258). 
Mário, por outro lado, embora sem ter condições de responder na prática como a sua "atitude estética" se relacionaria à arquitetura (e como o fazer do artistaarquiteto se relacionaria à indústria, à tecnologia etc.), na década de 1940 deixa claro, através de exemplos, qual seriam os caminhos que melhor responderiam, a seu ver, às exigências de um "justo equilíbrio" entre o artista (no caso, o arquiteto) e a sociedade. Em um artigo comentando a exposição Brazil builds ${ }^{61}$, depois de qualificar a casa moderna legítima como sublime, define-a por meio das seguintes contraposições: "O Ministério da Educação e jamais o Ministério da Guerra; o edifício Esther e jamais a Faculdade de Direito; uma morada de Artigas e jamais uma moradia neocolonial"62. Repare-se que, ao mesmo tempo em que o neocolonial é descartado, Mário lembra de Vilanova Artigas (que nesse momento iniciava a sua carreira como arquiteto moderno e não tinha sido incluído na celebre exposição); além disso, revela a sua admiração pelos projetos de Lucio Costa, destacando neles justamente o princípio artesanal ${ }^{63}$.

As proposições de Mário - sua participação e autocrítica em relação a 22, a leitura do passado e a proposta de tradicionalização do presente, a defesa da "atitude estética" - não serão esquecidas pelas gerações seguintes, na São Paulo das décadas de 1940 e 1950. Por um lado, os jovens estudiosos de formação sociológica do grupo Clima mostrar-se-ão seus admiradores, partindo da produção dos modernistas como base para a sua produção de crítica literária, artística e social64; por outro, inúmeros jovens artistas e arquitetos se lançarão à discussão de

61 A exposição, cujo subtítulo era "Arquitetura Nova e Antiga: 1652-1942", estruturava-se em dois pólos temáticos: a produção moderna - uma seleção de obras no Rio de Janeiro, Minas Gerais, Bahia, Pernambuco e São Paulo - e a arquitetura tradicional - cujas obras foram selecionadas com apoio do SPHAN e compreendiam majoritariamente exemplares tombados pelo órgão. Compunha-se de painéis fotográficos e respectivos textos explicativos, maquetes e ainda de um audiovisual; como produto final foi publicado o livro Brazil Builds, de autoria de Philip Goodwin. No Brasil, foi montada inicialmente no Rio de Janeiro e posteriormente em Belo Horizonte, São Paulo, Santos, Campinas, Curitiba, Florianópolis, Porto Alegre e Jundiaí (CARRILHO, Marcos. "Brazil builds: 55 anos da exposição". São Paulo, 1998. Disponível em <www.piniweb.com.br/construcao/noticias/brazil-builds---55-anos-da-exposicao-84648-1. asp>. Acesso em 5/5/2010).

62 ANDRADE, M. "Brazil builds", 1943. In: Vv Aa. Depoimentos 1. São Paulo, CEB/GFAU, 1960, p. 48. 63 Mário não especifica, em seu artigo sobre a exposição Brazil Builds, quais as obras de Costa que admira; o catálogo da exposição inclui apenas duas obras do arquiteto carioca: o Pavilhão de Nova lorque (projetado em 1939 em parceria com Niemeyer) e o edifício do Ministério da Educação (1936-1947). Mas, em 1943, ano do artigo de Mário de Andrade, Costa já havia projetado a Vila Monlevade (1934), e o Park Hotel em Nova Friburgo (1940), trabalhos nos quais o princípio artesanal parece estar fortemente presente e que provavelmente eram conhecidos por Mário.

64 Neste trabalho, como veremos mais adiante, interessa-nos particularmente o crítico de arte e cientista político Lourival Gomes Machado, admirador de Mário de Andrade e do modernismo de 22, mas também em consonância com as posições de Lucio Costa em suas colocações sobre acerca da moderna arquitetura e de sua relação com o passado. 
suas teses, refletindo-as e desdobrando-as em suas próprias obras (aqui, Vilanova Artigas será o exemplo mais expressivo). Como atesta o arquiteto Luis Saia, que aponta a década de 1940 como momento em que se evidencia a existência de "uma área comum de sentimento dos problemas nacionais e dos problemas da arte, capaz de conduzir a uma unidade da inteligência paulista", e remete essa unidade, entre outros fatores, ao "poder de polarização" exercido por Mário "cujo prestigio de cultura e inteligência transbordava facilmente do âmbito de suas preocupações exclusivamente literárias e musicais", influenciando "todos aqueles cuja sensibilidade procurava um apoio em termos desconhecidos pelo formalismo acadêmico e pelo aristocratismo artístico" ${ }^{65}$.

65 SAIA, L. "Arquitetura paulista", 1959. In: XAVIER, A. [org]. Depoimento de uma geração: arquitetura moderna brasileira. São Paulo, Cosacnaify, 2003, p. 111. 


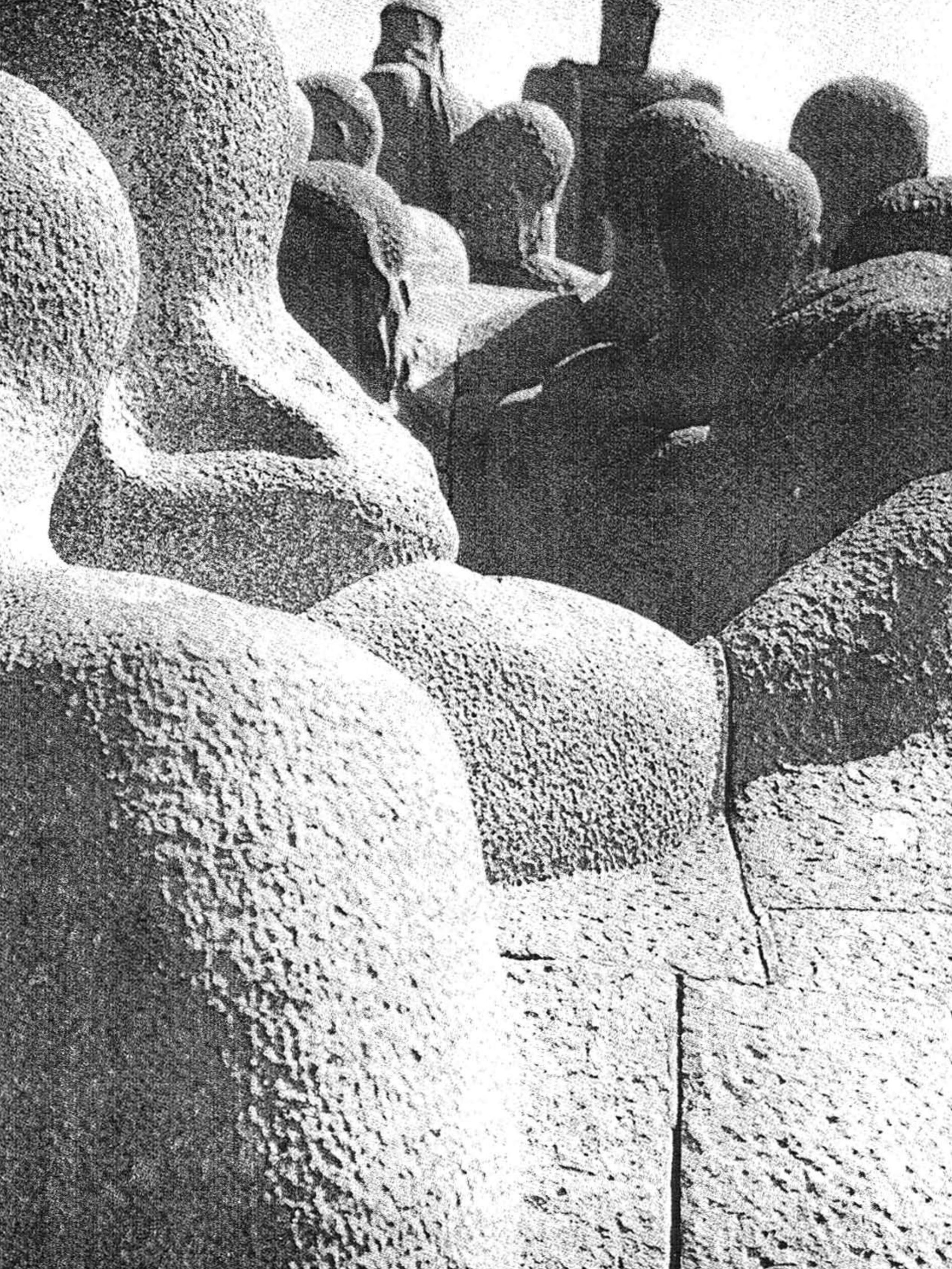


fig 2 [página anterior]

Monumento às Bandeiras (São Paulo),

de Victor Brecheret

fotógrafo não identificado 
capítulo 2

\section{flávio motta e a problematização da história}

1954 é o ano do IV Centenário da Cidade de São Paulo e as comemorações, em preparação desde o início da década, concretizam-se na construção do Parque do Ibirapuera, que passa a centralizar os principais eventos oficiais - como a "Exposição da Indústria" e a "Exposição da História de São Paulo". A estes, somam-se inúmeros eventos paralelos: a II Bienal de Artes, o Festival Internacional de Cinema, as apresentações do Ballet do IV Centenário, a Exposição de Pintura Italiana, a Exposição de Numismática, a de Artesanato dos Estados Unidos, o Salão Internacional de Fotografia Artística, dezenas de congressos profissionais (dentre os quais o IV Congresso de Arquitetos') e concursos - como o do cartaz oficial do IV Centenário e o da Bienal². As publicações são parte importante da celebração; jornais e revistas preparam edições especiais ${ }^{3}$, e a própria comissão organizadora patrocina a "biografia" da cidade 4 , cria a "Revista do IV Centenário" 5 e publica antologias de textos referentes à São Paulo quadricentenária.

\footnotetext{
1 O IV Congresso tinha como tinha como temas o ensino e profissão tanto da arquitetura quanto do urbanismo, além de mesas como "urbanismo e realidade nacional", "arquitetura e tradição" e "arquitetura e indústria". O evento contou com participantes estrangeiros importantes, como Walter Gropius (1883-1969), que publica nos anais do congresso o texto "O arquiteto na sociedade industrial". Estava prevista também uma exposição de caráter histórico, para mostrar "a evolução da arquitetura brasileira", mas esta acaba não sendo realizada. O nome de Motta, que nesse período já estava bastante envolvido com os arquitetos, consta na lista de participantes publicada nos Anais (ANAIS do IV Congresso Brasileiro de Arquitetos. São Paulo, 1954).

2 LOURENÇO, M. C. F. Operários da modernidade. São Paulo, Edusp/ Hucitec, 1994, p. 225-226.

3 O melhor exemplo parece-nos a Edição do IV Centenário, um caderno com centenas de páginas, publicado pelo Estado de São Paulo em 25/01/1954. Além dos artigos sobre os mais diversos temas "paulistas" (assinados tanto por críticos e historiadores já estabelecidos, como Afonso Taunay (1876-1958), quanto pela jovem geração de críticos como Lourival Gomes Machado e Antonio Candido), encontramos nessa edição um extenso conjunto de peças publicitárias que, recorrendo ao "elo entre o passado e o futuro da cidade", reproduzem exaustivamente a expressão "a cidade que mais cresce no mundo", ressaltando a "glória bandeirante" e a possibilidade de um "futuro esplêndido" (sobre a publicidade no IV Centenário, ver LOFEGO, S. "A construção da memória na publicidade do IV Centenário da Cidade de São Paulo". In: Revista Patrimônio e memória no. 2. São Paulo, Unesp/ FCLAs/ CEDAP, 2006, p. 32-51).

4 Referimo-nos a De comunidade à metrópole: biografia de São Paulo, do historiador norte-americano Richard Morse. O livro foi publicado em 1954 pela Comissão do IV Centenário/ Serviço de Comemorações Culturais.

5 Parcialmente disponível em <www.abril.com.br/especial450/indice.html>. Acesso em 29/05/2010.
} 

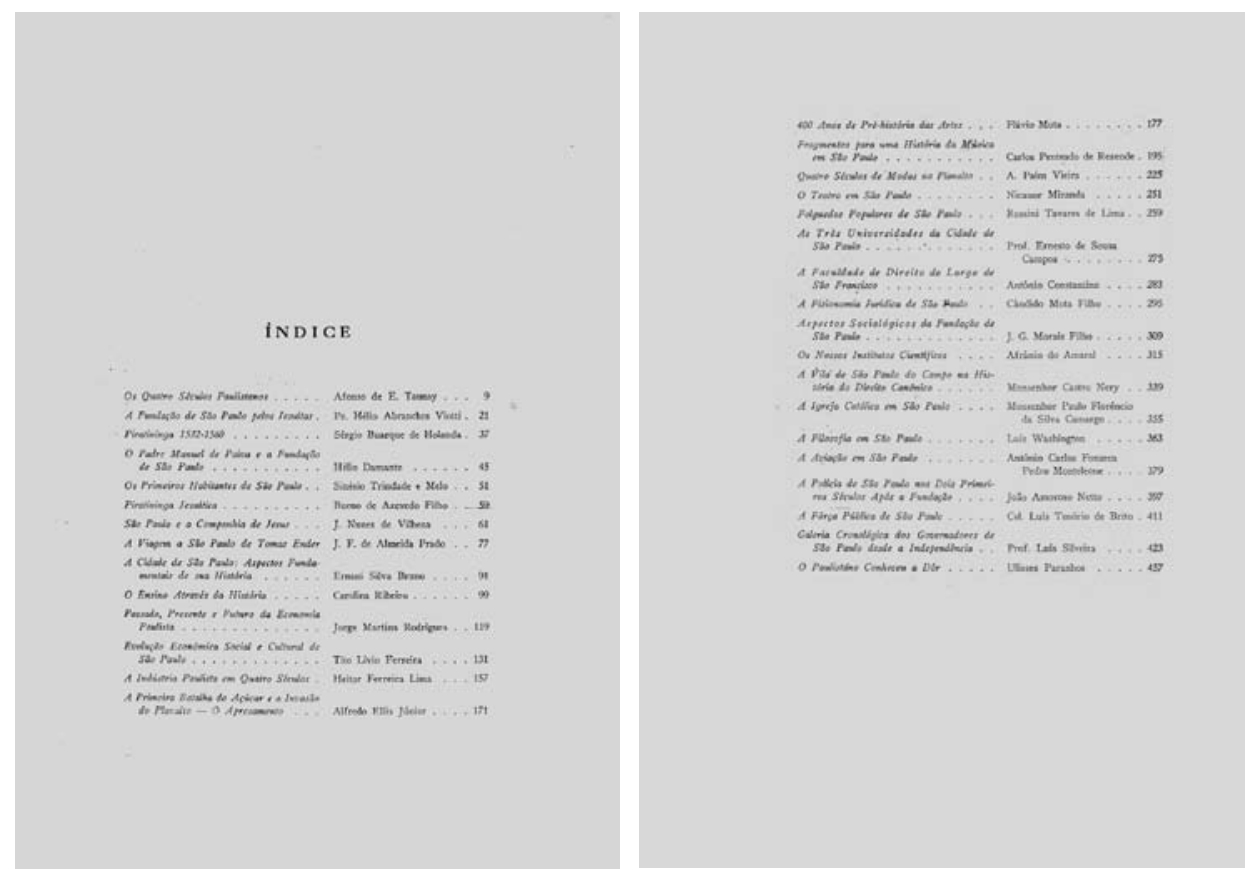

É justamente em uma dessas antologias que aparece o texto "400 anos de préhistória das artes", de Flávio Motta, ao lado de dezenas de outros artigos que tratam do desenvolvimento histórico e de aspectos específicos da cidade de São Paulo - educação, indústria, economia, artes, ciência, filosofia, e mesmo (tratando-se de uma publicação oficial e bem ao espírito da conservadora sociedade paulistana), a igreja católica ou a polícia.

O texto de Motta, no qual iremos nos deter no presente capítulo, faz um percurso cronológico pela história das artes e arquitetura paulistas, das primeiras obras do período colonial à inauguração dos museus de arte, já no final da década de 1940. A nosso ver, esse trabalho tem uma dupla importância. Em relação à trajetória de seu próprio autor - que há poucos anos iniciara seu trabalho como crítico e professor de história da arte, enquanto assistente de Pietro Maria Bardi no Museu de Arte e colaborador da revista Habitat ${ }^{6}{ }^{6}$, constitui uma primeira síntese de referências históricas e artísticas que serão constantemente re-trabalhadas nos anos seguintes.

6 Motta trabalhou no MASP de 1947 até meados da década de 1950. Durante esse período, não apenas foi assistente de Bardi, como também chegou a ser diretor-interino do Museu, na ausência do italiano; ministrou diversos cursos de história da arte (como o "Curso popular de introdução à arte", em 1950, e o programa "Vídeo de arte", na TV Tupi, em 1952), além de ter sido co-editor do boletim O Museu. Foi editor da Habitat durante o ano de 1953, e é nesta revista que publica alguns de seus primeiros textos, como "Verde em São Paulo", "Diana addormentata", "Saul Steinberg no Brasil" (em 1952) e a "A época do SPAM" e "São Paulo e o art nouveau" (em 1953). 
Num plano mais geral, a importância do texto reside em sua dissonância frente ao caráter das comemorações do IV Centenário, resumidas por Maria Arminda Arruda como um "ritual de celebração do poder dos paulistas"7. A construção das imagens de uma cidade (e de uma população) progressista e moderna ampara-se no uso sistemático da história e da tradição, uma conjunção que muitas vezes adquire um viés fortemente conservador:

Ao mesmo tempo em que se referencia a tradição, reafirma-se o novo, o atual, as tendências de transformação, mas de um modo em que o passado não seja totalmente deglutido. Nesse andamento, o uso sistemático da história serve de fonte legitimadora de certas práticas sociais, material que permite a integração das diferenças, segundo especifica orientação. Essas linguagens, que obscurecem e revelam a vida social, são momentos integrantes de uma dimensão ritualizada das práticas. ${ }^{8}$

O trabalho de retrospecção histórica e o ponto de visita paulista - que na maioria dos textos comemorativos funcionavam como reafirmações do ambiente de generalizado chauvinismo - propiciam a Motta a possibilidade de elaborar um novo viés historiográfico, em que a busca de uma linha de desenvolvimento cultural não implica necessariamente em "integração das diferenças".

Assim, veremos como, em relação à história da arte e arquitetura, "400 anos..." alinha-se às posições críticas da Habitat, e, apoiado em Mário de Andrade, repropõe os termos da ligação entre tradição e atualidade. Uma analise minuciosa mostra como Motta evita a concepção da história como mero relato ou ordenação cronológica de fatos artísticos sem perspectiva crítica (presente, a nosso ver, em muitas análises retrospectivas feitas à época, entre elas a de Luis Martins ${ }^{9}$ ). E mostra também como o autor sutilmente contrapõe-se ao que hoje é considerada a "trama dominante" 10 de interpretação historiográfica do movimento moderno

7 ARRUDA, M. A. Metrópole e cultura: São Paulo no meio do século XX. São Paulo, Edusc, 2001, p. 70-71.

8 lbid., p. 81-82.

9 Martins, jornalista e escritor carioca que se mudou para São Paulo na década de 1940, foi durante décadas crítico de arte e cronista do jornal O Estado de São Paulo. O seu texto "A arte paulista nos séculos XIX e XX", publicado na Edição Especial do IV Centenário, é especialmente interessante, para o nosso trabalho: por ter sido publicado na mesma época que "400 anos" e por realizar um percurso aparentemente muito próximo ao do texto de Motta, arrolando os mesmos personagens e manifestações artísticas. Entretanto, mais adiante, veremos como as duas análises se distanciam.

10 O termo é do arquiteto e pesquisador Carlos Ferreira Martins. Para o autor, essa "trama" é constituída por pelo menos três pontos fundamentais: a existência de uma arquitetura fortemente ligada ao Estado, que a elege como "linguagem oficial"; a idéia de que a arquitetura moderna brasileira não representaria um rompimento com o passado tradicional (o que traria também a idéia de uma "naturalidade" ou "inevitabilidade da emergência da linguagem moderna no Brasil"); e a sua "estratégia de omissão" 
brasileiro - em especial à identificação de um "espírito geral de nossa arquitetura", uno e contínuo, a partir do qual seria possível construir uma ligação direta e indissociável entre o passado colonial (ou a "boa tradição" luso-brasileira) e a arquitetura moderna ${ }^{11}$.

\subsection{Lourival Gomes Machado: o trabalho do historiador da arte no Brasil}

Escrevia Lourival Gomes Machado, em Retrato da arte moderna no Brasil, de 1947:

O primeiro historiador da arte brasileira, sistemático e com visão geral do desenvolvimento cultural, erudito e capaz de interpretação, este ainda não o tivemos. Monografias soberbas aparecem por vezes e, em muitas oportunidades, uma monografia - por exemplo, sobre o Aleijadinho - vale pelo estudo de uma época ${ }^{12}$. Não basta, contudo. Ficarão provisoriamente faltando aqueles estudos em que, mais que o grande artista ou o período bem caracterizado, constituam as ligações, as passagens intermédias, as transições, o interesse central do historiador (...) só é história verdadeira a que mostrar como a cultura transita se transformando, como os padrões adquirem uma medida de evolução, de crescimento. ${ }^{13}$

Retrato da arte moderna no Brasil é fundamentalmente uma análise do modernismo de 22 e de sua influência nas gerações posteriores (a "geração de 30", a "geração de 40" e os "novíssimos"14) - abrangendo manifestações como a pintura, a escultura e a arquitetura. Mas, na primeira parte do livro, como vimos, o autor também discute a posição do crítico e historiador das artes no Brasil.

Apontando o "corte individualizante" e o "monografismo obsedante" 15 como claros sintomas das dificuldades enfrentadas pelo historiador da arte brasileira,

ou "silenciamento" acerca de valores, autores e escolas - entre eles o ecletismo, a tradição acadêmica, Warchavchik ou Flávio de Carvalho (MARTINS, C. F. "A constituição da trama narrativa na historiografia da arquitetura moderna brasileira". In: Revista Pós, no. especial. São Paulo, FAUUSP, 1994, p. 93).

11 Em 1954, quando Motta publica seu texto, parte dessa "trama" já estava tecida; primeiro, pela obra ensaística de Lúcio Costa da década de 1930 e em sua atuação no SPAN; em seguida, pela exposição Brazil Builds, que em 1943 contribui fortemente para consolidar, nacional e internacionalmente, essa relação entre o moderno e uma determinada leitura do passado nacional (Cf. nota 24 do Capítulo 1).

120 autor se refere aqui ao trabalho de Mário de Andrade, "O Aleijadinho e sua posição nacional", de 1928.

13 MACHADO, L. G. Retrato da arte moderna do Brasil. São Paulo, Depto. de Cultura, 1947, p. 11.

14 lbid., p. 93.

15 Explica Lourival: "Ora, o historiador da arte brasileira (...) freqüentemente se embevece com as peculiaridades individualizantes. Nosso constante interesse por saber se determinado púlpito foi obra de padre erudito, de preto escravo ou de índio manso, embora muito nos tenha revelado de inesperado e esclarecedor, quase sempre nos tem obstado o discernimento de certas linhas de generalidade cultural, por um lado, e, por outro, a denotação diferenciadora dos vários núcleos. Talvez precisássemos resistir um pouco à emoção da beleza concretizada nas peças e, friamente científicos, propor-nos o problema em termos de maior rigidez lógica". (Ibid., p. 14-15) 
Lourival coloca a necessidade do trabalho crítico "friamente cientifico", ou seja, o trabalho que, reconstituindo as "linhas de generalidade cultural", fosse capaz de tratar da "ligações, transições, passagens intermédias" entre artistas, períodos e movimentos.

Esse ponto de vista generalista não deve, segundo o autor, ser confundido com a noção de uma "falsa continuidade linear" do desenvolvimento da nacionalidade ou da nação, com vistas à construção de uma "enorme unidade política". Pelo contrário, do ponto de vista cientifico, a análise da generalidade cultural implicaria num reconhecimento da história como "luta humana" e da formação da nacionalidade como "construção sofrida e conquistada"16; seria uma "tomada de consciência" acerca da realidade do próprio país, possibilitando um "revisionismo objetivo e necessário" 17.

Flávio Motta, em "400 anos de pré-história das artes", irá claramente partir da discussão lançada por Lourival. Logo no primeiro parágrafo do texto, refere-se ao professor ${ }^{18}$ e destaca em sua obra justamente a preocupação com a ausência do historiador da arte "sistemático e com visão geral do desenvolvimento cultural":

Voltar os olhos para trás, buscar na própria cidade quadricentenária exemplo de um surto de arte nas proporções do atual, seria procurar em vão. Talvez encontremos alguns nomes interessantes, valores isolados ou esculturas soberbas como as do século XVII, mas, considerando-se globalmente, a linha mestra do nosso desenvolvimento artístico ainda está se definindo. Pelo que temos diante dos olhos, como reflexo do nosso passado, o instante atual pertence ao primeiro capítulo: é a nossa pré-história em 400 anos de arte ${ }^{19}$. Temos, é bem verdade, o ânimo e a vontade dos pioneiros que vêem o passado perdido na noite do tempo. Aliás, várias gerações estão convencidas de que foram pioneiras. Na realidade o foram, como nós somos, mas num só capítulo - a pré-história. Pouco existe sobre a história de nossas artes. Para ela poderíamos

16 MACHADO, L. G. Retrato da arte moderna do Brasil. São Paulo, Depto. de Cultura, 1947, p. 13. 17 Ibid., p. 12-13.

18 Na década de 1950, Lourival, além de professor na cadeira de política na Faculdade de Filosofia da Universidade de São Paulo, era também professor na Faculdade de Arquitetura e Urbanismo, e foi um dos responsáveis pela introdução da disciplina de história da arte nesta escola. Por volta de 1954, entretanto, - Conselho Universitário exige que o professor opte por uma das duas cadeiras; Lourival afasta-se da FAU, e a partir de 1955 Motta passa a ocupar a sua cadeira. No inicio da década de 1960 Lourival volta à FAU, como diretor; em 1962 é criado o Departamento de História da Arquitetura e Estética do Projeto, cujo primeiro docente é Flávio Motta (Fontes: Depoimento de Flávio Motta à autora em 05/08/2009, Depoimento de Julio Katinsky à autora em 20/08/2009 e ZANINI, W. "Arte e história da arte". In: Revista Estudos Avançados 8(22), 1994, p. 487-489).

19 A própria noção de "pré-história", em Motta, talvez esteja referida a Lourival, quando este afirma que "o quanto sabemos do Brasil-Colônia, secção primeira da história nacional, diz que essa época além de já ser, com seus núcleos vigorosos e quase estanques, o desmentido formal da historiografia linear de nossos compêndios, vale ainda como um início obscuro e apenas aflorado; dir-se-ia uma proto-história". (MACHADO, L. G. Op. Cit., p. 13-14). 
repetir aquilo que escreveu o prof. Lourival Gomes Machado no seu Retrato da Arte Moderna no Brasil: 'O primeiro historiador da arte brasileira, sistemático e com visão geral do desenvolvimento cultural, erudito e capaz de interpretação, este ainda não o tivemos. Monografias soberbas aparecem por vezes e, em muitas oportunidades, uma monografia - por exemplo sobre o Aleijadinho - vale pelo estudo de uma época' ${ }^{20}$

Motta percebe as dificuldades da proposta de Lourival; como poderia o historiador realizar um trabalho de sistematização, a partir de um passado repleto de lacunas, de uma arte constituída por valores isolados? Como falar em desenvolvimento cultural, em evolução, numa cidade onde mesmo a arte moderna é identificada como um surto? À primeira vista, parece que Motta irá tentar contornar (e não resolver) tais problemas - ao apontar que seu trabalho, em "400 anos...", seria o de uma simples uma ordenação de fatos, um "rápido relato":

Não queremos discordar do prof. Lourival Gomes Machado. Desejamos apenas ordenar alguns fatos com certo respeito às fontes, arrolando, às vezes, aspectos curiosos e sacrificando mesmo as proporções dos acontecimentos, tendo em conta a finalidade deste rápido relato. ${ }^{21}$

Entretanto, ao longo do texto, revela-se que a preocupação com a visão sistemática irá estruturar a análise de "400 anos..." - e permite-nos ver, nas entrelinhas do relato cronológico, o surgimento de uma nova forma de pensar o desenvolvimento artístico e arquitetônico nacional.

\subsection{Flávio Motta}

\section{um percurso por "400 anos de pré-história das artes"}

Retomemos o percurso do texto, começando pelo fim. Depois de apontar a importância da criação do Museu de Arte Moderna, das Bienais (com claro predomínio da "arte abstrata" e "concreta" 22) e, em especial, do Museu de Arte (MASP) - que, além de exposições de artistas e arquitetos destacados, conferências, concertos, sessões de cinema, promoveu vários cursos com a intenção de "estabelecer mais íntimas relações entre a arte e a indústria" e "formar ambiente, criando interesse pelas artes" 23 - Motta expõe o que acredita ser o sentido de toda essa movimentação, na qual ele próprio se inclui com entusiasmo:

20 MOTTA, F. "400 anos de pré-história das artes". In: Vv Aa. IV Centenário da Cidade de São Paulo. São Paulo, Gráfica Municipal, 1954, p. 177. Grifo nosso.

$21 \mathrm{lbid}$.

22 lbid., p. 193

23 Motta refere-se especificamente aos cursos do Instituto de Arte Contemporânea (Ibid., p. 192-193), no qual foi professor de história da arte no Curso de Formação de Professores de Desenho. O IAC, apesar de sua curta duração (de 1951 a 1953), teve bastante impacto no meio cultural paulistano; nele formaram-se os artistas e designers que inaugurarão o campo do design no Brasil, como Antonio Maluf (1926-2005), Alexandre Wollner (1928) e Mauricio Nogueira Lima (1930-1999), entre outros (LEON, E. "O Instituto de Arte Contemporânea do Museu de Arte de São Paulo". In: Revista Desígnio, no. 5. São Paulo, 2006, p. 147-162). 
Apesar de todos esses esforços dotando o ambiente de São Paulo dos instrumentos fundamentais que são revistas, exposições, escolas e museus, resta garantir uma obra educativa contínua, cujos resultados colheremos, por enquanto, cabe apenas concluir: procuramos criar um clima de permanente interesse pela arte e a cultura, ligála o mais possível à vida; torná-la necessidade de um povo, consolidar uma tradição de trabalho e amor à atividade criadora, construir a história, enfim. ${ }^{24}$

O autor afirma, assim, que construir a história é questão central em "400 anos..." - problema que já estava esboçado desde o primeiro parágrafo, quando se refere a Lourival e ao trabalho do historiador. Seguindo a tradição dos pensadores da formação, dentre os quais se formou ele próprio, enquanto crítico de arte ${ }^{25}$, Motta também parte do propósito construtivo de "dotar o país de linhas evolutivas que culminem no funcionamento coerente de um sistema cultural local" ${ }^{26}$. Um propósito que não se realiza sem continuidade - sem uma "obra educativa contínua" - e sem um ambiente propício, que permita a consolidação de uma "tradição de trabalho" no campo da arte, da arquitetura e da cultura.

Fiel a essa tentativa de estabelecimento de um sistema cultural, a todo momento reafirma que, na arte paulista, o aparecimento de um clima ou tradição de trabalho por diversas vezes fora ensaiado. Agora, refazendo o percurso do texto a partir do seu início, veremos como a insistência de Motta sobre a formação de um sistema (que passa inclusive a ser um dos critérios para a definição de quais manifestações, personalidades ou movimentos farão parte do relato), não o impede de reconhecer a fragilidade de cada uma das manifestações artísticas, seu isolamento em relação umas às outras, sua descontinuidade.

O ponto de partida de "400 anos..." é o período colonial, em que Motta localiza as primeiras construções: a arquitetura rural pesquisada por Luis Saia - antigas sedes de fazendas, "raras páginas vivas da nossa história arquitetônica (...) constantemente ameaçadas pela nossa fé no progresso" 27; e as igrejas dos jesuítas,

24 MOTTA, F. "400 anos de pré-história das artes". In: Vv Aa. IV Centenário da Cidade de São Paulo. São Paulo, Gráfica Municipal, 1954, p. 193.

25 Motta não se reporta apenas a Lourival. Sabemos que foi aluno de Antonio Candido (1918), na Faculdade de Filosofia; como veremos mais à frente, sem dúvida podemos encontrar correspondências entre a sua proposta de revisão da história da arte brasileira, na década de 1950, e Formação da Literatura Brasileira, de 1959.

26 ARANTES, O. "Esquema de Lucio Costa". In: NOBRE, A. L. et al [orgs]. Um modo de ser moderno: Lucio Costa e a crítica contemporânea. São Paulo, Cosacnaify, 2004, p. 96.

27 Esta colocação não é nada ingênua: em tempos de IV Centenário, apontar que as casas bandeiristas estavam sendo destruídas pela "fé no progresso" é uma espécie de provocação, já que havia um esforço generalizado - por parte da Comissão Organizadora, do governo, das indústrias patrocinadoras, da imprensa - de associação entre o progresso da "cidade que mais cresce no mundo" e a figura primordial do heróico bandeirante. 
franciscanos e beneditinos, caracterizadas pela simplicidade estrutural e de fachadas, em contraste com a linha barroca das obras de talhe dos púlpitos e altares - igrejas que se diferenciariam daquelas dos outros estados brasileiros (em especial Minas Gerais e Bahia) por seu "limitado barroquismo"28.

Sem muito rigor em relação às datas ${ }^{29}$, Motta irá destacar, dentre os primeiros pintores, José Patrício da Silva Manso (17??-1801) e Miguel Arcanjo Benício Dutra (1810-1875), que trabalharam na cidade de Itu, "o Faubourg Saint-Germain da província de São Paulo"30. A estas "expressões autênticas" da São Paulo colonial acrescenta o escultor frei Agostinho de Jesus (c. 1600-1661) e o pintor Jesuíno do Monte Carmelo (1764-1819), em quem irá se deter. Padre Jesuíno passa a ser figura constante na historiografia da arte brasileira após a recuperação de sua obra por Mário de Andrade, em 1945³1. Segundo Mário,

(...) dentro do barroco a obra do padre Jesuíno do Monte Carmelo representa uma realidade cultural inferior (...) Jesuíno fica nesse entremeio malestarento entre a arte folclórica legítima e a arte erudita legítima (...) ele é o culto sem tradição por detrás (...) o culto sem cultura. Também nisto ele se reconfirma no grupo dos artistas brasileiros da Colônia, e representa com mais agudeza que a maioria deles, o que era a cultura artística nacional do seu tempo. ${ }^{32}$

Motta, que considera Mário "um dos homens que melhor visão e estudo alcançou do problema da cultura artística no Brasil"33, chama atenção justamente para o desajuste que o modernista identifica no pintor colonial: problematicamente, Jesuíno é um "culto sem cultura". E faz um alerta, apontando que, longe de ser característica exclusiva de um passado morto e distante, esse "estado de coisas

28 MOTTA, F. "400 anos de pré-história das artes". In: Vv Aa. IV Centenário da Cidade de São Paulo. São Paulo, Gráfica Municipal, 1954, p. 178.

29 Motta parece aqui considerar o período colonial como uma grande unidade, tanto que não se preocupa em diferenciar os artistas dos três primeiros séculos. Não é o único autor a fazer isso - lembremos da construção de Lucio Costa, à procura de um "espírito geral" na arquitetura do período colonial. Mas as motivações de Motta, como veremos mais à frente, são diferentes daquelas do arquiteto carioca: percebemos que a falta de "detalhamento" da arte colonial, em "400 anos...", deve-se mais à orientação do texto como um todo (que, proporcionalmente, dá muito mais espaço às manifestações do século XIX e XX) do que à construção intencional de uma unidade colonial que poderia servir de modelo às manifestações contemporâneas.

30 MOTTA, F. "400 anos de pré-história das artes". In: Vv Aa. IV Centenário da Cidade de São Paulo. São Paulo, Gráfica Municipal, 1954, p. 180.

31 ANDRADE, M. Padre Jesuíno do Monte Carmelo. In: Revista do SPHAN, no. 14. Rio de Janeiro, MES, 1945.

32 Citado por MOTTA, F. "400 anos de pré-história das artes". In: Vv Aa. IV Centenário da Cidade de São Paulo. São Paulo, Gráfica Municipal, 1954, p. 179. Grifos nossos. 33 lbid. 
(...) prolonga-se sempre que se procura vencer o popular ou torná-lo erudito sem o aprendizado justo". ${ }^{34}$

Motta destaca que esses primeiros pintores estavam "livres da profunda influência exercida pela Missão Francesa, a partir de 1816 e, depois, da Academia Nacional de Belas Artes". Mas, no Segundo Império, o estímulo da família imperial contribui para o surgimento de um "movimento amplo", que, atingindo São Paulo, oferecerá ao ituano José Ferraz de Almeida Júnior (1850-1899) um "ambiente e possibilidades maiores de trabalho".

Muitos críticos, inclusive os mais atuais, procuraram ver na obra de Almeida Júnior, por sua predileção pelo "assunto caipira" e sua "paleta clara", um artista tipicamente brasileiro. Mas ele, de certo modo, repete a idéia de Mário de Andrade, permanecendo "nesse entremeio malestarento entre a arte folclórica legitima e a arte erudita legítima". Aliás, para ser mais exato, nem seria erudita, porque o academismo que estudou com Cabanel era uma coisa extemporânea e o folclórico nem sempre estava nas cores e sim mais no assunto. Entretanto, teve grande influência. ${ }^{35}$

A referência a Almeida Júnior tem uma dupla função, no texto de Motta: comprova a tese da persistência das deficiências e contradições artísticas brasileiras (mais um "culto sem cultura"!) e demonstra que mesmo um academismo "extemporâneo" poderia, no Brasil, ser valorizado enquanto parte da história - na medida em que influencia outros pintores:

Os pintores acadêmicos formaram em São Paulo uma tradição de artistas medíocres. Entretanto, seria justo dizer que eles chegaram a criar um clima, com nomes como Oscar Pereira da Silva, o último premiado da monarquia; Pedro Alexandrino (...) um dos muitos brasileiros que passaram pela França, já em pleno fim de século e não perceberam o impressionismo. Além dos já mencionados (...) outros concorreram para formar o ambiente acadêmico que se concentrou e ainda se concentra, empobrecido, no Salão Paulista de Belas Artes, na Escola de Belas Artes, no Serviço de Fiscalização Artística e na Pinacoteca do Estado. (...)

O movimento acadêmico, devido à proteção, primeiro imperial, depois do governo da República, consolidou-se mais no Rio de Janeiro. Aqui a Escola de Belas Artes, que deveria ser o centro de irradiação, pouco ou quase nada pôde fazer, lutando, inclusive, com falta de recursos. Julgamos oportuno tratar isoladamente o fenômeno acadêmico, porque na história, ele mesmo, por conta própria, procurou sempre ignorá-la e caminhar fora do tempo. Por isso que os livros sérios sobre História da Arte colocam à margem a pintura acadêmica. Nós, entretanto, sentimos necessidade, devido às finalidades desse artigo, de respeitar um grupo que fez ambiente e atuou na realidade da vida paulista. ${ }^{36}$

34 MOTTA, F. "400 anos de pré-história das artes". In: Vv Aa. IV Centenário da Cidade de São Paulo. São Paulo, Gráfica Municipal, 1954, p. 179.

35 Ibid., p. 181.

36 Ibid., p. 182. Grifo nosso. 
Do "fenômeno acadêmico", o autor passa então às primeiras décadas do século $X X$, quando se acabam os dias de isolamento paulista. É a época do café, identificada como um "ambiente de riqueza e de progresso" que, além de revelar "o espírito empreendedor dos grandes paulistas" 37 , traz à cidade maturidade intelectual e um princípio de industrialização - que se refletirão em iniciativas como a fundação, em 1873, da Sociedade Propagadora da Instrução Popular (posteriormente transformada em Liceu de Artes e Ofícios):

Tinha esse movimento por objetivo a democratização da cultura (...) ० problema da educação artística estava sendo colocado, considerando suas raízes, longe dos cânones acadêmicos, dentro de um sentido justo da realidade, pois, com a conversão da Sociedade em Liceu (...) a educação artística procurava manter-se ligada às novas técnicas de trabalho e às condições econômicas de São Paulo, com o apoio das classes produtoras ${ }^{38}$, dos fazendeiros de café, dos técnicos e com um vivo interesse do povo em geral. ${ }^{39}$

A partir daí, tudo começa a se conectar, no texto; Motta parece ter chegado ao que talvez seja o seu interesse maior: o momento histórico em que as tentativas de estabelecimento de uma tradição artística se ligam às tentativas de industrialização, em que arte e técnica, ou arte e trabalho, passam a ser dois pólos de uma mesma equação. Francisco de Paula Ramos de Azevedo (1851-1928), apesar de em relação à arquitetura "ter-se mantido dentro dos cânones acadêmicos", como organizador do Liceu presta "inestimáveis serviços à cultura paulista", ao lado de seu auxiliar Luiz Scattolini:

Eles, muito cedo, precedendo a países de adiantada evolução técnica, compreenderam que era necessário ligar a arte à indústria, porque a indústria, através de produção em massa, difundiria o gosto e criaria melhores condições de subsistência para o artista contemporâneo. ${ }^{40}$

O Liceu, a partir de 1900, torna-se o centro de difusão do art nouveau, reunindo artesãos valorosos - a maior parte deles imigrantes italianos; "qualquer artífice ou mestre de valor que chegava do estrangeiro era conquistado para o Liceu".

37 A posição de Motta, na década de 1950, expressa uma avaliação da realidade brasileira então comum em diversos setores da classe média (intelectuais, técnicos, artistas etc). Na passagem de um país fundamentalmente agrário e rural para um país urbano e industrial, defendem um programa de desenvolvimento nacional, fundamentado na indústria e na aliança com a burguesia industrial, vista como força progressista e esclarecida. A partir disso, é possível entender melhor as novas posições trazidas por Motta e as manifestações artísticas por ele valorizadas, assim como sua admiração pelas iniciativas em favor do ensino universal e da "democratização da cultura".

38 No contexto em que "400 anos..." é escrito, e conforme a nota anterior, "classes produtoras", para Motta, parece ser sinônimo de burguesia urbana - industriais e comerciantes, ou os responsáveis pela administração e direção dos processos produtivos que impulsionavam o crescimento econômico do Brasil naquele momento.

39 MOTTA, F. "400 anos de pré-história das artes". In: Vv Aa. IV Centenário da Cidade de São Paulo. São Paulo, Gráfica Municipal, 1954, p. 183.

40 lbid. 
Segundo o autor, nesse momento, aperfeiçoa-se muito "a execução e o desenho", a ponto dos móveis e objetos produzidos pela escola se tornarem sucesso de público (eram vendidos rapidamente) e crítica (um deles chega a ser premiado na Exposição Universal de Saint Louis, em 1904) ${ }^{41}$.

A partir do art nouveau Motta introduz a obra dos arquitetos - a maior parte deles, também estrangeiros - em seu percurso. Este estilo, "que caracterizava uma renovação do gosto da época, evitando a repetição de estilos passados" ${ }^{42}$, tem razoável penetração em São Paulo; estará presente nas obras de Carlos Ekman (1866-1940) - arquiteto da Vila Penteado, símbolo do art nouveau em São Paulo, e que posteriormente se transformará na sede da faculdade de arquitetura - e do francês Victor Dubugras (1868-1933) ${ }^{43}$. Além de destacar a forte personalidade e o temperamento de Dubugras ("homem de fantasia extraordinária, impunha e não transigia em matéria de arquitetura"), situa-o dentre os pioneiros do movimento moderno, em seus projetos de residências (muitas delas ameaçadas de demolição, na década de 1950), escolas e cadeias ${ }^{44}$. Gregori Warchavchik, por sua vez, é também um pioneiro, pois "trouxe, antes da passagem de Le Corbusier pelo Brasil, uma importante contribuição para a nossa arquitetura contemporânea, realizando as primeiras construções modernas com aquela orientação 'funcional', em São Paulo e no Brasil"45.

O modernismo de 22, e o que veio depois dele, ocupam boa parte do relato de Motta, que afirma (sem desenvolver o argumento) que "a importância de 1922, foi maior do ponto de vista literário que plástico"; essa importância residiria (novamente) no fato de "como movimento" o modernismo criar "um ambiente propício à arte renovadora e antiacadêmica".

Contando que 22 e os movimentos posteriores estariam amplamente documen$\operatorname{tados}^{46}$, Motta se refere brevemente a Lasar Segall (1891-1957), considerado "o

41 MOTTA, F. "400 anos de pré-história das artes". In: Vv Aa. IV Centenário da Cidade de São Paulo. São Paulo, Gráfica Municipal, 1954, p. 184.

42 Ibid., p. 183.

43 Motta menciona também vários arquitetos "acadêmicos" que trabalharam em São Paulo, sem se deter em suas obras ou biografias - como, por exemplo, Thomazio Gaudenzio Bezzi (1844-1915), Maximiliano Hehl (?-1916) ou Domiciano Rossi (1865?-1920) (Ibid., p. 185).

44 Ibid., p. 185.

45 Ibid.

46 É curiosa essa afirmação do autor, pois apenas um ano antes, em 1953, o próprio Motta preocupavase em documentar e recuperar as atividades da Sociedade Pró Arte Moderna (SPAM), em texto publicado na Habitat (MOTTA, F. "A época do SPAM". In: Revista Habitat, v. 11, jun 1953, p. 49-60). Na década de 1960, quando já era professor da FAU-USP, Motta organizou, junto aos alunos da escola, um extensivo 
primeiro moderno de verdade", Anita Malfatti (1889-1964) e Tarsila do Amaral (1886-1973). Relata o surgimento da idéia de realização da Semana de Arte Moderna, nos encontros dos escritores Oswald de Andrade (1890-1954) e Guilherme de Almeida (1890-1969), aos quais se junta o pintor Di Cavalcanti (1897-1976) e depois vários outros. A história do movimento, a seu ver, poderia ser resumida pela frase publicada na Revista Anual do Salão de Maio (RASM): "nós somos os primitivos de uma nova era"47.

Lembra do movimento Pau-Brasil e da Antropofagia, e, já na década de 1930, aponta que "nesses movimentos modernos paulistas" sempre havia a reunião de pintores, escultores, músicos e arquitetos. Refere-se especialmente ao Clube dos Artistas Modernos (CAM) e a seu presidente Flávio de Carvalho (1899-1973):

Diz o mesmo, referindo-se ao Clube, que "o ambiente era acolhedor e irresponsável". Isso demonstra que o liberalismo inglês influenciou Flávio de Carvalho. Naturalmente uma influência um pouco exagerada que levou o artista a desenhar e pintar dentro de uma técnica muito pessoal, misto de art nouveau com linhas de força expressionista e violência nas cores. ${ }^{48}$

O CAM traz uma série de novidades. Não apenas pela figura e obra de Flávio de Carvalho: o clube organiza, com a ajuda de Mário Pedrosa (1901-1981), a exposição da alemã Kathe Kollwitz (1867-1945); com a ajuda de Tarsila, uma exposição de cartazes russos; discute a arte das crianças e dos loucos; promove o Teatro da Experiência, que causa escândalo ao encenar o Bailado do Deus Morto e acaba sendo fechado pela polícia.

Já a Sociedade Pró Arte Moderna (SPAM), criada na mesma época que o CAM, caracteriza-se pela tentativa de estabelecimento de um "ambiente" para as artes - promovendo concertos, conferências, bailes célebres - como "Carnaval na cidade de Spam", "As matas virgens de Spamolândia", "KWY" - e exposições de artistas importantes - como De Chirico (1888-1978), Picasso (1881-1973), Léger (1881-1955), Brancusi (1876-1957), Le Corbusier, entre muitos outros. Motta avalia, assim, "de lá para cá nada aconteceu semelhante a SPAM; no sentido de

trabalho de levantamento das obras dos modernistas - dentre os quais Victor Brecheret (1894-1955), Anita Malfatti e Candido Portinari (1903-1962) - que incluiu não apenas pesquisa fotográfica e documental, mas também a realização de entrevistas e depoimentos com os próprios artistas (parte desse material, que inclui gravações em áudio, encontra-se, até onde sabemos, arquivado no Laboratório de Vídeo da FAUUSP).

47 MOTTA, F. "400 anos de pré-história das artes". In: Vv Aa. IV Centenário da Cidade de São Paulo. São Paulo, Gráfica Municipal, 1954, p. 187.

48 Ibid., p. 189. 
preocupação de ambiente, de aproximar artistas de todos os gêneros, num clima de liberdade" 49.

Por fim, antes de relatar o nascimento dos museus e a importante "obra educativa" a eles relacionada, Motta passa rapidamente pelo Salão de Maio (no qual ressalta a participação de Quirino da Silva (1902-1981) e Flávio de Carvalho na organização e promoção das exposições, que ocorrem apenas três vezes, em 1937, 1938 e 1939) ${ }^{50}$, detendo-se no que chama de "isolacionismo" das artes em São Paulo: na década de 1940, "a arquitetura, a música, o teatro, desenvolveram-se isoladamente" ${ }^{51}$.

Na pintura, esse problema reflete-se na fugacidade e descontinuidade das tentativas de criação de um ambiente e de instrumentos de trabalho. Ao final da década os pintores, reunindo-se na Galeria Domus, tentam criar jornais ${ }^{52}$ e manter vivo seu sindicato, que agonizava. Recebem apoio de "um ou outro intelectual" mais ligado aos artistas ("Sergio Milliet, Lourival Gomes Machado e Luís Martins"), que procuram "fazer de homens simples e pintores despretensiosos, razão para manter vivo o assunto de Arte" - Motta, aqui, certamente está se referindo à "família artística paulista", identificando, mais uma vez, a repetição da "história de Mário de Andrade quando falava sobre o padre Jesuíno, 'o culto sem cultura'" 53 .

Os novos arquitetos paulistas também enfrentam dificuldades. Em São Paulo ainda se luta pela aceitação dos princípios da arquitetura moderna - apesar do prestigio internacional de figuras como Niemeyer e Lucio Costa -, e devido ao isolamento entre as artes, os "modernismos" anteriores parecem pouco contribuir para a afirmação arquitetônica da nova geração ${ }^{54}$, pois a atmosfera por eles criada não chegou a se transformar em tradição:

49 MOTTA, F. "400 anos de pré-história das artes". In: Vv Aa. IV Centenário da Cidade de São Paulo. São Paulo, Gráfica Municipal, 1954, p. 189.

50 Ibid., p. 190.

51 lbid., p. 192

52 Motta refere-se especificamente ao Jornal das Artes e ao jornal Artes plásticas - do qual ele próprio participa, juntamente com Ciro Mendes, Clóvis Graciano (1907-1988) e Cláudio Abramo (1923-1987), em 1948.

53 Ibid., p. 192.

54 Notemos que a percepção de Motta é muito ligada ao momento em que escreve o texto. Hoje - como discutiremos mais adiante - nos parece impossível não relacionar a emergência da arquitetura moderna em São Paulo (a partir da década de 1940) e principalmente, o seu desenvolvimento, a certas posições e questões do modernismo das décadas anteriores. 
Principalmente a arquitetura passou a seguir, depois de Warchavchik, apesar de certa autonomia, a orientação contemporânea que prestigiou o Brasil no exterior com as figuras de renome como Oscar Niemeyer, Lúcio Costa e os irmãos Roberto. A geração que hoje aqui está, Rino Levi, Abelardo de Sousa, Vilanova Artigas, Osvaldo Bratke etc., lutando ainda para impor aceitação dos princípios da arquitetura contemporânea, é uma geração que se formou à parte de uma contribuição direta desses nossos "movimentos modernos", que criaram atmosfera, mas, não criaram tradição de trabalho. Cessado o entusiasmo dos dias de festa, ficou pouco, muito pouco. ${ }^{55}$

\subsection{Motta e Mário de Andrade}

\section{A história problematizada ou um sistema assistemático}

Havíamos anteriormente afirmado que a visão sistemática estruturaria a análise de "400 anos...", e que, nas entrelinhas do relato cronológico, estaria presente uma nova forma de pensar o desenvolvimento artístico e arquitetônico nacional. Para compreender essas características do trabalho de Motta - que é uma espécie de renovação da operação de tradicionalização do presente, em plena década de 1950 - precisamos necessariamente refazer as ligações entre o autor e Mário de Andrade.

Motta não apenas admira o modernista (admiração expressa na referência ao estudo sobre Padre Jesuíno, e em diversas ocasiões posteriores ${ }^{56}$ ), mas principalmente se identifica - mesmo que não chegue a formular isso claramente, enquanto programa de trabalho - com o caminho da problematização histórica, tal como formulada por Mário. Como, no texto de Flávio Motta que analisamos aqui, se dá essa problematização da história e quais os seus elementos?

\footnotetext{
55 Além de um entendimento de que a arquitetura necessariamente precisa ser inserida no contexto mais geral da cultura e das artes, é interessante notar que, aqui, Motta identifica e nomeia quem são os arquitetos da nova geração que surgia em São Paulo (MOTTA, F. "400 anos de pré-história das artes". In: Vv Aa. IV Centenário da Cidade de São Paulo. São Paulo, Gráfica Municipal, 1954, p. 192). Note-se que críticos que escrevem no mesmo contexto que o autor, como Luis Martins, não têm essa percepção; este último destaca, em seu texto sobre a arte paulista, apenas Rino Levi e Jacques Pilon (que povoaram "a cidade e seus arrabaldes de imponentes arranha-céus e magníficas residências"), e o Ibirapuera de Niemeyer (MARTINS, L. "A arte paulista nos séculos XIX e XX". In: O Estado de São Paulo, Edição do IV Centenário, 25/01/1954, p. 139).

56 Dentre elas, a organização da antologia Depoimentos 2, com textos de Mário de Andrade, publicada em 1966 pelo Centro de Estudos Brasileiros do GFAU (AMARAL, A. "Como era Mário de Andrade?". In: Textos do Trópico de Capricórnio, v. 1. São Paulo, 34, 2006, p. 36); e a republicação, no início da

década de 1970, dos textos "Esta Paulista família" (escrito por Mário em 1939) e "Ensaio sobre Clovis Graciano" (de 1944 e até então inédito).
} 
No sentido da arte e da cultura como elementos essenciais para a caracterização da nação ${ }^{57}$, há em "400 anos..." um reconhecimento de que a história da arte, em São Paulo, é feita de manifestações limitadas, irregulares, insuficientes, em suma, de "boatos falsos da nacionalidade" - manifestações que poderiam bem se encaixar na definição que Mário dava ao Aleijadinho em 1928:

(...) engenho já nacional, era o maior boato falso da nacionalidade, ao mesmo tempo que caracterizava toda a falsificação da nossa entidade civilizada, feita não de desenvolvimento interno, natural, que vai do centro para a periferia e se torna excêntrica por expansão, mas de importações acomodatícias e irregulares, artificial, vinda do exterior. ${ }^{58}$

Até aqui, nada de novo no trabalho de Motta: a "pobreza artística" paulista já era reconhecida pelo próprio Mário, que, décadas antes, apontava que, da cidade dos primeiros séculos, não seria possível "esperar-se grande coisa com valor artístico tradicional" 59 .

No entanto, "400 anos..." mantém sempre a perspectiva da continuidade entre as várias manifestações artísticas, e uma preocupação central do ideal da formação: aquela da criação de um sistema ${ }^{60}$. E por isso Motta é obrigado a inventar - e aqui está a principal novidade - um sistema assistemático, pois no passado artístico e arquitetônico paulista a única constante é a inconstância, a irregularidade $^{61}$. É clara a relação com a formulação de Antonio Candido (que sem dúvida

57 A associação entre as artes e a "civilização" não é incomum: Antonio Candido, por exemplo, considera a literatura (enquanto sistema de obras ligadas por denominadores comuns) como um "fenômeno da civilização". A frase de Rui Barbosa, "Não se pode viver dentro da Civilização e fora da Arte", era uma das frases preferidas de Pietro Bardi e era escrita, a giz, na grande lousa do auditório principal do MASP na Rua Sete de Abril (junto à uma mesa italiana do século XVI e às cadeiras modernas projetadas por Lina bo Bardi).

58 ANDRADE, M. "O Aleijadinho e sua posição nacional", 1928. In: Depoimentos 2. São Paulo, CEB/ GFAU, 1966, p. 25-26.

59 Outros autores reiteraram essa visão, como Luis Martins, que ao referir-se à contribuição de São Paulo às artes plásticas e arquitetura brasileiras, considera-a "muito recente" - não encontrando no passado paulista "nada que exprima uma afirmação de originalidade criadora capaz de rivalizar com a estatuária do Aleijadinho ou com a pintura da 'escola baiana'. O passado artístico de São Paulo é muito pobre" (MARTINS, Luis. "A arte paulista nos séculos XIX e XX". In: O Estado de São Paulo, Edição do IV Centenário, 25/01/1954, p. 137).

60 Não custa relembrar: a "formação" é idéia que supõe "o ideal de seriação, concatenação, continuidade, tradição (...) um sistema de referências recíprocas por oposições às manifestações avulsas e isoladas" (ARANTES, O. "Esquema de Lucio Costa". In: NOBRE, A. L. et al [orgs]. Um modo de ser moderno: Lucio Costa e a crítica contemporânea. São Paulo, Cosacnaify, 2004, p. 96).

61 Veremos como essa leitura posteriormente passará a valer não apenas para São Paulo, mas para todo o Brasil. 
também se remete a Mário de Andrade), de que "um autor e uma obra podem ser e não ser alguma coisa, sendo duas coisas opostas simultaneamente" ${ }^{2}$, ou seja, da aceitação do contraditório como essencial ao trabalho do crítico ${ }^{63}$.

Para Motta, o que liga os pontos desconexos, as manifestações artísticas isoladas, é que todas elas têm em comum o fato de terem sido tentativas - a maior parte delas fracassadas, débeis reações à lógica da "civilização transplantada"64 - de criação de um clima ou (o que seria ainda mais desejável) de uma tradição de trabalho. Essa valorização da tradição já vinha sendo feita por Mário de Andrade, desde meados da década de 1930; no texto sobre a Família Artística Paulista, por exemplo, a "função social" de Lasar Segall é justamente a de construir ambiente para a produção artística:

Ao lado do nenhemnhém desses ótimos artesãos, eis que surge a lição fortíssima de Lasar Segall. Este felizmente ajuntava à grande cultura técnica mas estreita dos outros dois [Vitório Gobbis e Paulo Rossi], uma verdadeira cultura estética e um poder criador excepcional. Neste sentido, a função que o grande pintor russo veio exercer em São Paulo foi inestimável. Ele vinha (...) justificar as aventuras da expressionista Anita Malfatti, da cubista Tarsila e a grita de nós outros (...) bem como preparar o respeito ambiente para todos os "malditos" que viessem depois. Essa foi a grande função social de Lasar Segall, entre nós, um construtor de ambiente. ${ }^{65}$

Para Mário, tradição é construção de ambiente de trabalho para os artistas; é valorização de uma consciência coletiva que - sem prescindir da personalidade

62 Discutindo o trabalho do crítico literário, cuja meta principal seria a tentativa de "focalizar simultaneamente a obra como realidade própria, e o contexto como sistema de obras", Candido explica: "Para chegar o mais perto possível do desígnio exposto, é necessário um movimento amplo e constante entre o geral e o particular, a síntese e a análise, a erudição e o gosto. É necessário um pendor para integrar contradições, inevitáveis quando se atenta, ao mesmo tempo, para o significado histórico do conjunto e o caráter singular dos autores. É preciso sentir, por vezes, que um autor e uma obra podem ser e não ser alguma coisa, sendo duas coisas opostas simultaneamente (...) Por isso, quem quiser ver em profundidade, tem de aceitar o contraditório, nos períodos e nos autores, porque, segundo uma frase justa, ele 'é o próprio nervo da vida'" (CANDIDO, A. Formação da literatura brasileira. Belo Horizonte, Itatiaia, 1981, p. 04).

63 Com o método da problematização histórica, um artista, uma obra ou um movimento podem ao mesmo tempo ser expressões da nacionalidade e a sua negação. Tomemos o exemplo do Liceu de Artes e Ofícios, tão caro a Motta: enquanto tentativa de ligação entre a arte e as massas (por meio da difusão do "gosto" pela indústria), assume um papel "civilizatório" e formativo; mas, esbarrando nas limitações maiores impostas pelas condições de desenvolvimento industrial, é a negação desse mesmo projeto.

64 Veremos como, em outros textos da década de 1950, Motta irá referir-se a determinadas manifestações artísticas brasileiras como exemplos de uma "civilização transplantada", reforçando esse caráter de uma arte e arquitetura cuja história é a história de "importações acomodatícias", absorvidas e reproduzidas a-criticamente no contexto nacional.

65 ANDRADE, M. "Esta Paulista Família", 1939. In: MOTTA, F. "Textos informes - A família artística paulista", Revista do IEB no. 10, 1971, p. 155. Grifos nossos. 
ou "solução pessoal", inatas a cada indivíduo ${ }^{66}$ - permite a estabilização e a continuidade da pesquisa estética ${ }^{67}$. É também condição necessária à realização de qualquer obra de arte - na medida em que viabiliza a produção e a transmissão de conhecimentos e técnicas imprescindíveis tanto ao "artesanato"68 (componente sem o qual, diz Mário, não há obra de arte verdadeira) quanto à "virtuosidade"69 (componente secundário, porém de grande utilidade para o artista) ${ }^{70}$.

Motta irá retomar estas concepções não apenas quando insiste em destacar as tentativas de criação de ambiente, pelos diversos artistas, movimentos e grupos que inclui em seu "rápido relato": atentemos para o surgimento, em "400 anos...", de um claro e inaudito interesse "formativo" pelas manifestações artísticas e arquitetônicas do final do século XIX e primeiras décadas do século XX - como, por exemplo, o Liceu e o art nouveau. Aprofundaremos a discussão no próximo capitulo, mas, desde já, podemos identificar dois pontos dignos de nota.

66 O trecho acima citado demonstra bem como Mário, referindo-se a Lasar Segall, estabelece uma relação dialética entre a personalidade de certos artistas ("poder criador") e a possibilidade de realização social da arte ("cultura técnica").

67 Ao fazer o célebre balanço do modernismo, em 1942, Mário avalia que uma das principais conquistas do movimento foi justamente ter conseguido conjugar, num "todo orgânico da consciência coletiva", três princípios fundamentais ("o direito permanente à pesquisa estética; a atualização da inteligência artística brasileira; e a estabilização de uma consciência criadora nacional"). (ANDRADE, M. "O movimento modernista", 1942. In: Aspectos da literatura brasileira. Belo Horizonte, Itatiaia, 2002, p. 266).

68 Como já exposto no Capítulo 1, Mário define o artesanato como o "aprendizado do material com que se faz a obra de arte", exigência material, mas também social e humana, a guiar a "verdade interior" do artista (Idem. "Curso de filosofia e história da arte", 1938. In: Depoimentos 2. São Paulo, CEB/GFAU, 1966, p. 31).

69 A virtuosidade é definida como "o conhecimento e prática das diversas técnicas históricas da arte", ou ainda "o conhecimento da técnica tradicional" (Ibid., p. 31).

70 Também seria interessante retomar, aqui, como essa questão da tradição aparece para Lucio Costa na década de 1950. A nosso ver, Motta trava um debate silencioso com o arquiteto; seu trabalho crítico deixa entrever que novas posições estavam a surgir, dentro do movimento moderno brasileiro, no que se refere à construção da identidade entre moderno e tradição e à concepção da relação entre artista e sociedade. Costa, ao avaliar que a arquitetura moderna é também brasileira "não somente porque renova uns tantos recursos superficiais peculiares à nossa tradição, mas fundamentalmente porque é a própria personalidade nacional que se expressa (...) através de determinadas individualidades do gênio artístico nativo", de certa forma abdica da criação de um sistema ou de uma tradição de trabalho (COSTA, L. "Depoimento de um arquiteto carioca", 1951. In: XAVIER, Alberto [org]. Lucio Costa: sobre arquitetura. Porto Alegre, UniRitter, 2007, p. 197). Motta propõe-se a recuperar a tradição enquanto fundamento necessário às artes e arquitetura brasileiras, mas seguindo uma outra linha e uma outra concepção de história, como já expusemos. Parece-nos que essa recuperação - em que tradição pode ser entendida num sentido histórico (a "má tradição" paulista, tradição de acadêmicos, imigrantes, cultos sem cultura...) ou no sentido da insistência na criação de um ambiente de trabalho para os artistas - opõe-se (ou, ao menos, relativiza a importância) da visão de Costa e o papel-chave por este conferido ao "gênio artístico nativo". 
Primeiramente, o que é valorizado nessas manifestações paulistas da Primeira República (1889-1930) é justamente o fato de expressarem tentativas (sempre tentativas...) de solução para o problema da separação entre arte e técnica, arte e indústria, num momento histórico em que as promessas de um país industrializado e modernizado em parte se tornavam realidade - sem que seus benefícios fossem, no entanto, estendidos à maior parte da população ${ }^{71}$. São também lidas como possibilidades de reconciliação entre arte e trabalho - na medida em que, se por um lado expressam um certo progressismo da burguesia, por outro recuperam o saber artesanal do trabalho imigrante, que será muito valorizado pelo autor.

Em segundo lugar, a inclusão dos séculos XIX e início do XX enquanto partes da história da arte no Brasil, significa que esses momentos deixam de ser considerados interrupções ou momentos de crise de uma nacionalidade em formação - como defendia boa parte da crítica moderna ou modernista, como Lucio Costa, a partir da década de $1930^{72}$, ou ainda Lourival Gomes Machado, na década de $1940^{73}$. Para Motta, o estudo do caso de São Paulo é ponto de partida para

71 A década de 1950 está em uma situação bastante diferente daquela da década de 1930, quando surgem as primeiras defesas de ligação entre as artes (e arquitetura) e a indústria. Por exemplo: em "Razões da nova arquitetura", de Lucio Costa, a industrialização da construção aparece apenas como promessa, que poderia talvez se tornar realidade se devidamente compreendida pelos "arquitetos, engenheiros, construtores e o público em geral"; os arquitetos modernos, com a "revisão dos valores plásticos tradicionais", estariam cumprindo a importante função de "abrir o caminho (...) à indústria" (COSTA, L. "Razões da nova arquitetura", 1933-35. In: XAVIER, A.[org]. Lucio Costa: sobre arquitetura. Porto Alegre, UniRitter, 2007, p. 28 et seq.).

72 É interessante notar que, na década de 1930, Lucio Costa se referia às primeiras décadas do séc. XX como um período de "desarrumação", de manifestações que não se enquadrariam na lenta evolução da arquitetura que vinha se processando "normalmente" desde a Colônia (Idem. "Documentação necessária", 1937. In: XAVIER, A. [org]. Op. cit., p. 91). Na década de 1950, curiosamente, embora continue a afirmar a "ausência de sentido evolutivo" desse momento, situando nele a "quebra definitiva da velha tradição", Costa detém-se, com uma atenção até então inédita, no que chama de "movimentos estilísticos" do período, no Rio de Janeiro. Detalha os diferentes estilos, retoma arquitetos e edifícios quase esquecidos (Idem. "Depoimento de um arquiteto carioca", 1951. In: XAVIER, A. [org]. Op. cit., passim.). 73 Lourival avalia que no século XIX, com a chegada ao Brasil de D. João VI e a Missão Francesa, é "sacrificada a cultura brotada do torrão", substituída por uma "cultura mais maleável e menos legitima, menos local e mais monárquica" (MACHADO, L. G. Retrato da arte moderna do Brasil. São Paulo, Depto. de Cultura, 1947, p. 19). A oposição entre as "manifestações autênticas", típicas do período colonial, e a "falsidade" das manifestações posteriores (com a qual, a seu ver, apenas o modernismo conseguirá romper), é uma constante nas análises de Lourival em Retrato. Permeia inclusive a sua visão sobre a arquitetura moderna, que curiosamente se aproxima de uma visão de "falsa continuidade linear", ao afirmar que entre a "nova arquitetura brasileira" e a "autêntica arquitetura dos tempos da colônia, só vai a diferença imposta pela dimensão temporal (...). Tão perfeita é a correspondência que, por vezes, o observador sente revelar-se no risco dos edifícios novos, não o cubismo europeu do mestre, mas a gratui- 
enxergar as manifestações do XIX em diante como partes da mesma lógica que regeu o Brasil colonial: aquela do país dependente, subordinado inicialmente à metrópole portuguesa, depois à expansão comercial da Inglaterra, e finalmente ao imperialismo norte-americano ${ }^{74}$. Em todos esses momentos, houve conjunturas propícias para a afirmação da nacionalidade e da criação de uma arte própria, original - mas, via de regra, todas elas se frustraram. Nos seus melhores momentos, foram novos "abortos luminosos"75 - e é a partir deles que Motta construirá o seu "projeto histórico-crítico".

dade e as ilusões de perspectivas que forma, em seu tempo, o apanágio do barroco, elemento histórico da arte no Brasil" (Ibidem, p. 82-83).

74 Motta não chega a usar o termo "imperialismo", como fazia à época Artigas; mas, como o arquiteto, tem uma perspectiva desenvolvimentista (que ficará mais clara em seus textos do fim da década de 1950) e de defesa da "emancipação nacional". A discussão acerca do "colonialismo cultural" estava presente desde meados da década de 1940 e se estende ao longo da década seguinte; ganha força com a realização das primeiras Bienais (quando o destaque dado à arte abstrata é visto por parte da intelectualidade brasileira como sinal de ingerência estrangeira) e atinge todas as artes; em 1951, por exemplo, Artigas qualifica a Bienal de "manobra imperialista" (ARTIGAS, V. "A Bienal é contra os artistas brasileiros". In: Caminhos da arquitetura. São Paulo, Cosacnaify, 2004, p. 31). Em 1954, aponta "a decadência da arquitetura como arte" como uma das conseqüências "da ação direta do imperialismo americano na superestrutura" (Idem. "Considerações sobre arquitetura brasileira". In: Op. Cit., p. 53).

75 Como vimos, a expressão é de Mário de Andrade, em "O Aleijadinho e sua posição nacional", de 1928. 



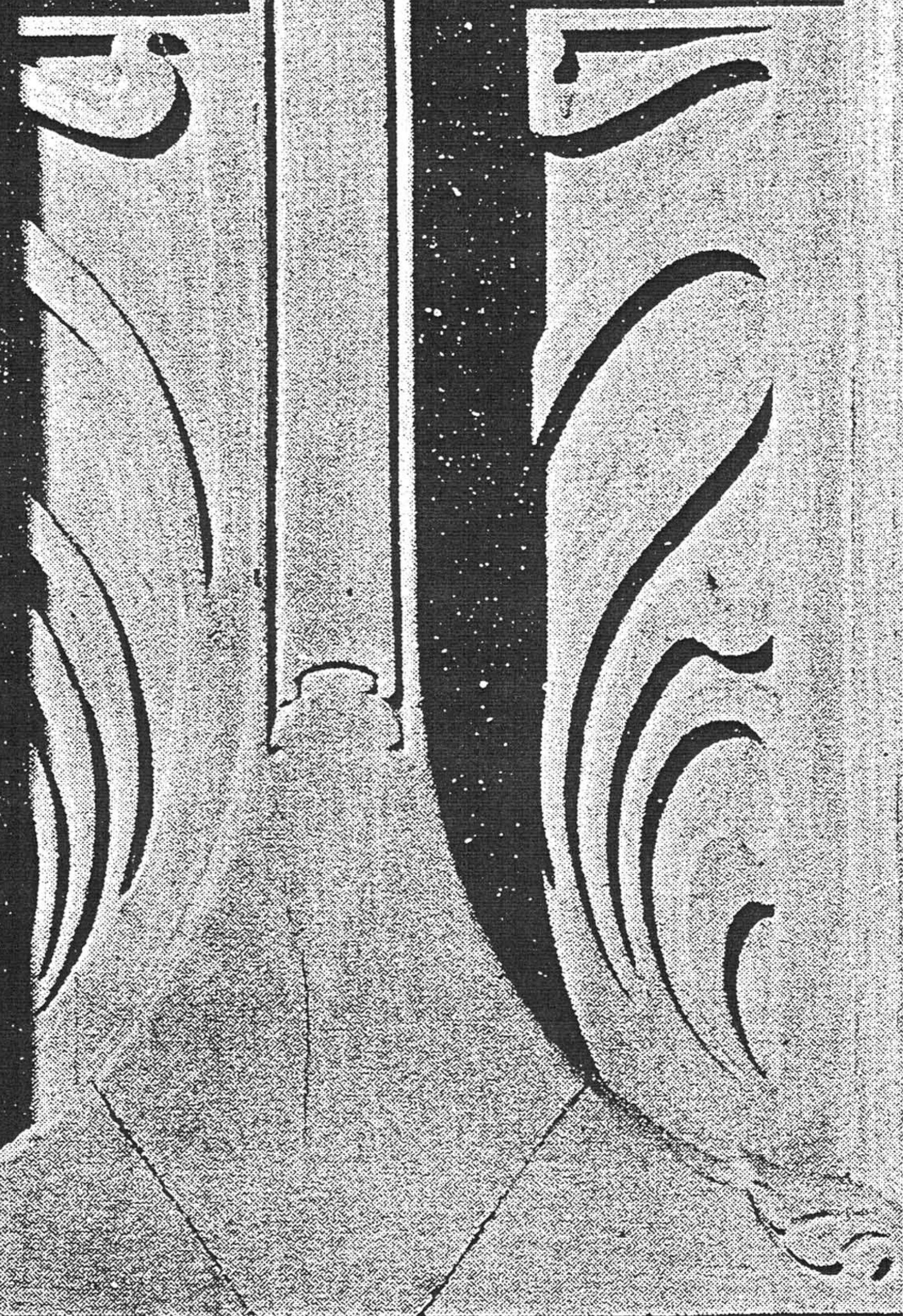


fig 4 [página anterior]

Vila Penteado (São Paulo), de Carlos Ekman

por Cristiano Mascaro 
capítulo 3

\section{do novo ao moderno: flávio motta e o art nouveau no brasil}

O tema do art nouveau - também chamado, no Brasil, de floreal ou liberty emerge pela primeira vez na obra de Motta em artigos publicados na revista Habitat ${ }^{1}$. Em seu primeiro número (out-dez 1950), um artigo de Motta denuncia a demolição iminente de uma residência art nouveau na rua Marques de Itu, em São Paulo, propondo a instalação de um “Museu Floreal" no imóvel ameaçado².

Anos mais tarde, no número 10 (jan-mar 1953), é publicado "São Paulo e o art nouveau". Nesse artigo, o interesse do autor pelo tema é justificado ainda pela urgente necessidade de proteger os monumentos do patrimônio histórico nacional, não apenas os monumentos barroco-coloniais mas também aqueles de outros estilos que teriam contribuído para a "formação artística do país". Destaca o significado do art nouveau dentro das inquietações do início do século XX ("um mundo que vacilava entre dois tipos de culturas de características antagônicas: o mundo do artesanato e o mundo da industrialização"), e procura, ainda de maneira inicial, trazer a discussão para o Brasil, buscando entender como esse estilo sem estilo se arraigou entre nós - fazendo-o a partir de algumas figuras-chave da cena cultural paulistana do início do século e do significado do Liceu de Artes e Ofícios de São Paulo³.

1 Surgida em 1950, muito ligada às ações culturais do Museu de Arte de São Paulo, a publicação será dirigida, em sua fase inicial (da fundação a 1954) por Lina bo Bardi e Pietro Maria Bardi. Nesse período, Motta é também muito próximo, a ponto de dirigir a revista no ano de 1953. Segundo Luis Hossaka, Habitat era feita "a seis mãos" - as de Lina, Bardi e Motta (In: STUCHI, F. Revista Habitat: um olhar moderno sobre os anos 50 em São Paulo. São Paulo, FAUUSP (Tese de Mestrado), 2006, p. 61). Em sua segunda fase (de 1955 a 1965), tem colaboradores como o crítico Geraldo Ferraz (1905-1979), que contribuem para manter sua "posição polemista" (In: MIRANDA, C. L. A crítica de arquitetura nos anos 50, a expressão plástica e a síntese das artes. São Carlos, EESC-USP (Tese de Mestrado), 1998, p. 76.).

2 A casa em questão é considerada pelo autor uma "uma das mais características de São Paulo, pois representa um estilo que teve aqui um certo desenvolvimento reflexo: o floreal". Além do interesse do imóvel em si mesmo - pois a residência era fartamente decorada, em suas portas, janelas, paredes, escadas e inúmeros outros detalhes - o museu deveria reunir "toda a sorte de antigos objetos", objetos "dum tempo [a Primeira República] tão intimamente ligado ao passado paulista" (MOTTA, F. "Um museu do estilo floreal em São Paulo". In: Revista Habitat, no. 1, 1950, p. 73).

3 MOTTA, F. "São Paulo e o art nouveau". In: Revista Habitat, no. 10, 1953. 


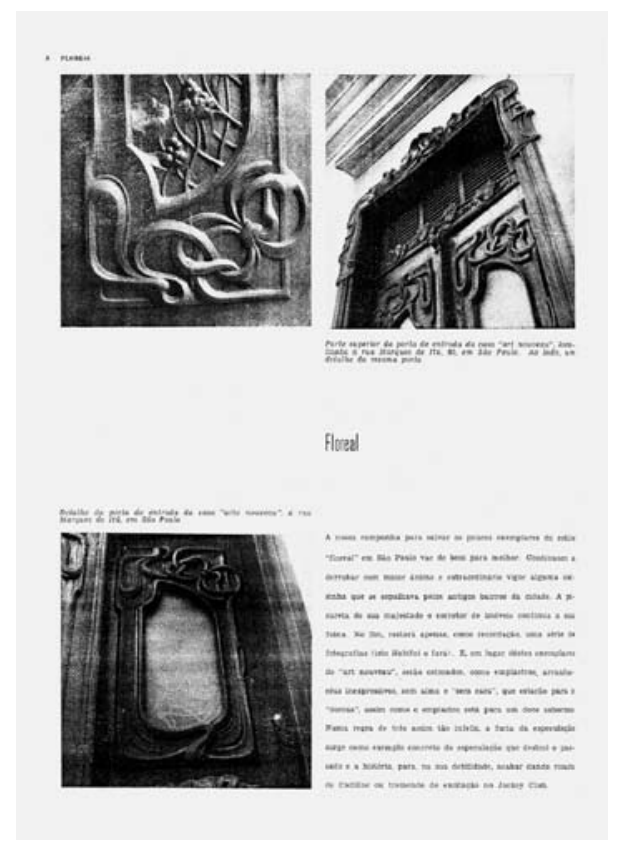

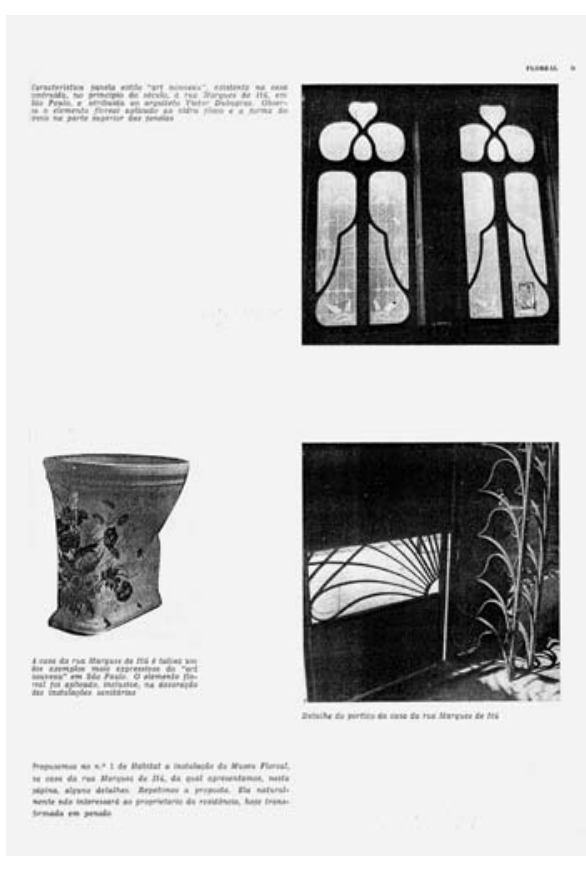

fig 5 [esq. e dir.]

Páginas do artigo "Floreal", publicado por Motta em Habitat 12 (1953)

Alguns meses depois, na Habitat número 12 (jul/set 1953), é retomada a campanha para salvação do "floreal" paulistano. Com pouco texto e muitas fotografias, o tom do artigo é bastante irônico4:

\begin{abstract}
A nossa campanha para salvar os poucos exemplares do estilo "floreal" em São Paulo vae de bem para melhor. Continuam a derrubar com maior animo e extraordinário vigor alguma coisinha que se espalhava pelos antigos bairros da cidade. A picareta de sua majestade o corretor de imóveis continua a sua faina. No fim, restará apenas, como recordação, uma série de fotografias (isto Habitat o fará). E, em lugar destes exemplares do art nouveau, serão colocados, como emplastros, arranha-céus inexpressivos, sem alma e sem "cara" (...) a fúria da especulação surge como exemplo concreto da especulação que destrói o passado e a história, para, na sua debilidade, acabar dando risada de Cadillac ou tremendo de excitação no Jockey Club. ${ }^{5}$
\end{abstract}

O último texto sobre o art nouveau escrito na década de 1950 é de 1957, quando Motta já lecionava História da Arte na Faculdade de Arquitetura e Urbanismo da Universidade de São Paulo: Contribuição ao estudo do art nouveau no Brasil é sua tese de cátedra, apresentada no concurso "à cadeira número 15" do Departamento de História da FAUUSP ${ }^{6}$. Na primeira parte do trabalho, situa as características do art nouveau na Europa, destacando os principais artistas que

$4 \mathrm{O}$ artigo não é assinado, porém é identificado por Stuchi como sendo de autoria de Motta (STUCHI, F. Revista Habitat: um olhar moderno sobre os anos 50 em São Paulo. São Paulo, FAUUSP (Tese de Mestrado), 2006, p. 165). De fato, as fotografias apresentadas e as colocações do texto são coerentes com o desenvolvimento posterior do tema, por esse autor.

5 MOTTA, F. "Floreal". In: Revista Habitat 12, 1953, p. 58-61.

6 Cf. nota 18, Capítulo 2. 

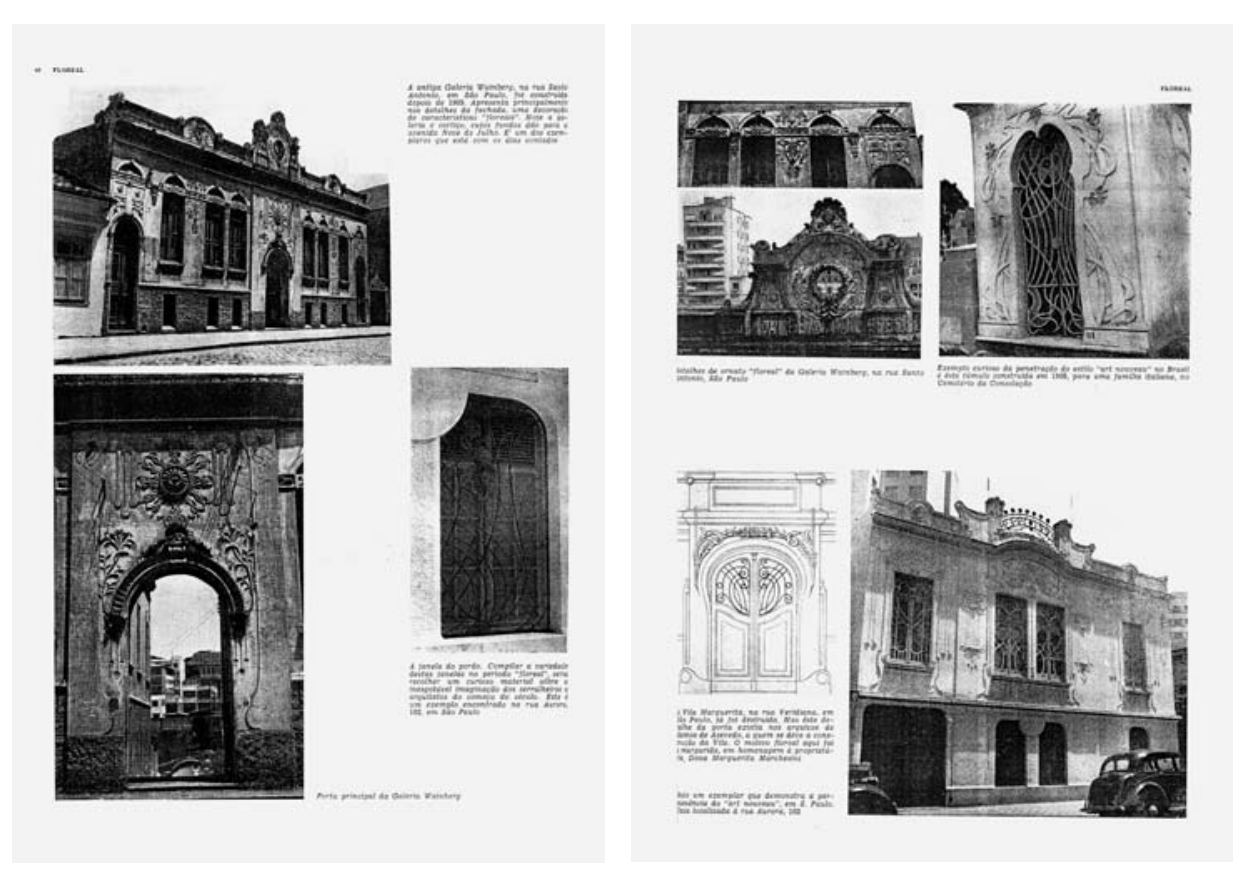

influenciaram ou participaram do movimento, como o arts and crafts inglês, o movimento belga e o sezession austríaco. Na segunda parte, volta-se para o fenômeno brasileiro, analisando-o em sua dimensão "antiacadêmica" e "cosmopolita", por meio de seus artistas mais expressivos - como o artista Eliseu Visconti (1866-1944), Carlos Ekman e Victor Dubugras e os artesãos do Liceu - e das diversas formas de manifestação (artes gráficas, artes decorativas, arquitetura) que o movimento conheceu no Brasil?.

Contribuição... aprofunda o estudo do tema do art nouveau, em suas relações com o surgimento do movimento moderno. Motta se apóia em historiadores e críticos como Lionello Venturi (1885-1961), Siegfried Giedion (1888-1968) e principalmente Nikolaus Pevsner (1902-1983). Procura, em seu trabalho, resgatar autores nacionais, como o crítico e professor Ernesto da Cunha Araújo Viana e o escritor e político Rui Barbosa (1849-1923), realizando uma extensa pesquisa e levantando documentos de época e entrevistando artistas e outras personalidades que tomaram parte do art nouveau, em São Paulo e no Rio de Janeiro.

7 MOTTA, F. Contribuição ao estudo do art nouveau no Brasil, 1957. Tese (Cátedra). São Paulo, FAUUSP, 1957.

8 No arquivo histórico do MASP, duas cartas de Motta a Pietro Maria Bardi, escritas em 1956, revelam o caminho percorrido pelo autor na elaboração de sua tese de cátedra. Nesses documentos, Motta destaca a sua intenção de "atingir a medida mais real possível do problema [do art nouveau], destacando-o do fundo histórico em que viveu", enumera artistas e periódicos que estava pesquisando, e menciona os resultados de suas viagens de pesquisa, pedindo conselhos ao professor Bardi. 
O interesse de Motta pelo art nouveau não se esgota nesses artigos da década de 1950; nas décadas seguintes, continuará a escrever sobre o tema. Em 1965, publica "Art nouveau: um estilo entre a flor e a máquina", em que sintetiza a discussão feita nos textos anteriores - centrando-se no significado do art nouveau para a história da arte no Brasil, no problema da industrialização e no problema do desenho enquanto conciliação entre técnica e arte ${ }^{9}$. Esse interesse constante, inclusive, parece ter levado a um reconhecimento de Motta enquanto especialista em arte e a arquitetura brasileiras no principio do século XX: em 1969 publica, no Dicionário das artes plásticas no Brasil, o texto "Visconti e o início do século XX"10; na década de 1980, escreve o verbete "Art nouveau, modernismo, ecletismo e industrialismo" para a enciclopédia de Walter Zanini ${ }^{11}$.

9 MOTTA, F. "Art nouveau, um estilo entre a flor e a máquina", 1965. São Paulo, Cadernos Brasileiros, v. 28, n. 2, p. 54-63, mar/abr. 1965.

10 Idem. "Visconti e o início do século XX". In: PONTUAL, R. Dicionário das artes plásticas no Brasil. RJ, Civilização Brasileira, 1969.

11 Idem. "Art nouveau, modernismo, ecletismo e industrialismo", 1983. In: ZANINI, W. História geral da arte no Brasil v. 1. São Paulo, Moreira Salles/ Djalma Guimarães, 1983. É interessante notar que o conjunto da produção de Motta sobre o período da Primeira República e especificamente sobre o art nouveau tem razoável influência na historiografia da arquitetura brasileira, a partir da década de 1960. O trabalho pioneiro de Motta se relaciona àquele de pesquisadores como Carlos Lemos (1925) e Nestor Goulart Reis Filho (1931), por exemplo. As preocupações de Lemos muitas vezes reverberam aquelas postas por Motta na década de 1950, ao escrever obras como Alvenaria Burguesa (obra de década de 1980 que historia a arquitetura residencial de tijolos em São Paulo, típica do final do século XIX e início do XX) ou Ramos de Azevedo e Seu Escritório (de 1993). Em relação a Nestor Goulart Reis Filho, basta dizer que o livro Quadro da arquitetura no Brasil, de 1970, uma importante referência no estudo da história da arquitetura brasileira, tem Contribuição ao estudo do art nouveau no Brasil como uma das poucas obras que constam em sua bibliografia. Parte da obra é dedicada à discussão das manifestações arquitetônicas e urbanísticas do século XIX e início do XX; o ecletismo, ao invés de ser desvalorizado, é estudado em seu contexto histórico e econômico, sendo considerado "um veiculo eficiente para a assimilação de inovações tecnológicas de importância" (REIS FILHO, N. G. Quadro da arquitetura no Brasil. São Paulo, Perspectiva, 2000, p. 169). O interesse do autor pelas manifestações da Primeira República irá se manter ao longo das décadas; em 1997, publica Racionalismo e protomodernismo na obra de Victor Dubugras - seguindo, a nosso ver, a consideração de Motta que, desde 1953, insistia em que "mereceriam um estudo à parte, a obra e a figura de Dubugras". Notemos, entretanto, que em muitos casos essa incorporação do século XIX, pela historiografia das artes e arquitetura, não assume o sentido crítico apontado originalmente por Motta, de problematização da história da arte no Brasil. O art nouveau, o ecletismo e outras manifestações do período são passivamente adicionados à história da arquitetura brasileira, como mais um capítulo, dentre tantos, de uma história ela própria historicista. Um exemplo disso é Arquitetura contemporânea no Brasil, de Yves Bruand, obra publicada no Brasil em 1981 e considerada marco referencial de nossa historiografia. O autor, ao deter-se no art nouveau, reproduz quase que literalmente as colocações de Motta nas décadas anteriores; insere, porém, o movimento em uma numerosa lista de estilos presentes na arquitetura brasileira da primeira metade do século XIX, os reunindo num capitulo cujo nome significativo é "De um ecletismo sem originalidade à afirmação internacional da nova arquitetura brasileira" (BRUAND, Y. Arquitetura contemporânea no Brasil. São Paulo, Perspectiva, 2008, p. 5). 
Entretanto, devido ao recorte temporal e à temática do presente trabalho, iremos nos concentrar nos textos escritos na década de 1950, quando o surge o interesse de Motta pelo art nouveau e quando a sua abordagem, inédita, se diferencia daquela de autores já consagrados como Lucio Costa e Lourival Gomes Machado.

\subsection{A rejeição ao art nouveau}

A posição de Motta, assim como a de Habitat - que na década de 1950 revalorizam o século XIX e suas manifestações ${ }^{12}$ - estavam longe de ser consensuais. Nas décadas de 1920 e 1930 a rejeição às manifestações da Primeira República dentre as quais o ecletismo, o art nouveau ${ }^{13}$ e o neocolonial (então partes de um passado recente) - poderia ser entendida como parte do embate entre modernistas e acadêmicos. Mas, nas décadas seguintes, essa rejeição - que implicava, por vezes, em uma leitura a-histórica do desenvolvimento artístico brasileiro - se mantinha e se reproduzia, mesmo com a suposta normalização do modernismo e da arquitetura moderna ${ }^{14}$, normalização que, em tese, pressuporia que tal embate teria deixado de estar no centro das preocupações de arquitetos e críticos.

Vejamos como Lourival Gomes Machado, em 1947, entende as manifestações do XIX e início do XX, especificamente o art nouveau. $\mathrm{O}$ autor reconhece que a arquitetura do período republicano ainda não tinha encontrado o "analista paciente" de que necessitava. Faz uma interessante análise da cidade de São Paulo nesse período, apontando como a imigração européia e as diferenças de classe adquirem expressões urbanísticas e arquitetônicas:

Houve a entrada, nessa época, dos elementos europeus provindos de dois pólos opostos - de um lado, a imigração estrangeira, sobretudo a italiana, trouxe-nos uma leva de artesãos rudimentares, de trabalhadores habituados a padrões formais fixos e imutáveis, que se incumbiram de adaptar à planta que tradicionalmente se fixara nas cidades brasileiras; por outra parte, o olhar dos ricos, voltado sempre, nessa

12 Mais adiante veremos como essa revalorização acontece em Habitat e como a posição de Motta se aproxima daquela da revista.

13 Em 1928, Mário de Andrade mostra-se aliviado pelo art nouveau ter sido apenas uma moda passageira: "(...) o estilo art nouveau também ficou em documentos medonhos e numerosos, porém o estilo não ficou. E graças da Deus!" (ANDRADE, M. "Arquitetura colonial", 1928. In: Arte em Revista no. 4, ago 1980, p. 13).

14 Em 1942, Mário identificava essa normalização no fato de que "hoje o artista brasileiro tem diante de uma verdade social, uma liberdade (infelizmente só estética), uma independência, um direito às suas inquietações e pesquisas (...). Quem se revolta mais, quem briga (...) contra a arquitetura do Ministério da Educação, contra os versos 'incompreensíveis' de um Murilo Mendes, contra o personalismo de um Guinard...? Tudo isto são hoje manifestações normais, discutíveis sempre, mas que não causam o menor escândalo público" (ANDRADE, M. "O movimento modernista", 1942. In: Aspectos da literatura brasileira. Belo Horizonte, Itatiaia, 2002, p. 276). 
época de folgança econômica que viria até 1929, para os modismos europeus, provocou a importação de um art nouveau por vezes quase grandioso (...) e de todo o batalhão de mofinos "estilos" regionais e pitorescos (...). Assim foi que os bairros ricos se encheram de inexpressivas aproximações de "suiços" e "normandos", provocando a reação de um "colonial" estranhamente misturado com o bungalow que logo entrou em fácil acomodação geradora dos mais inesperados hibridismos formais. Enquanto isso, a casa modesta só conhecia o mesmo impacto que, advindo nos primeiros anos da República, já assentara uma fisionomia de fachada sem entrar pela casa adentro. Os pedreiros responsáveis por essa modificação (...) chamam-se, na gíria profissional, "frentistas". De fato, a sua ação nunca passou da frente da casa; para além da parede externa desenvolve-se, nas construções dos bairros hoje chamados pobres, a mesma distribuição tradicional, espécie de adaptação do plano das casas rurais da zona cafeeira às condições e às dimensões urbanas. ${ }^{15}$

Lourival não se detém nas possíveis influências do trabalho dos "artesãos rudimentares" sobre a arquitetura de "mofinos estilos", e vice-versa. $O$ surto arquitetônico do período em questão resultou apenas em construções "fachadistas" (por parte dos trabalhadores) e "estilísticas" (pela burguesia). Tal arquitetura em nada contribuiria à renovação arquitetônica que estava por vir, na medida em que

(...) procurou rivalizar em decadentismo com a pintura e a escultura das academias. Aconteceu que o dinheiro farto, disposto a tudo comprar, encontrou nas grandes cidades européias o art nouveau, não o art nouveau da liberdade quase onírica de formas arbitrárias, mais tarde uma das raízes do surrealismo, mas aquele com aspecto de superabundância ostentatória, ridiculamente perdulária, cheia de má estatuária, espanejando descabelamentos, espastelada de gessos em baixos relevos vagamente mitológicos, com uma pintura feita de propósito, para chamar a atenção. ${ }^{16}$

Não podemos dizer que a leitura de Lourival seja a-histórica; original e muito relevante, a sua leitura procura associar o desenvolvimento arquitetônico às condições materiais e políticas do desenvolvimento de São Paulo. Entretanto, quando confrontamos esse pensamento acerca do período republicano com sua reflexão sobre a arquitetura moderna, não temos como deixar de apontar a existência de um indicio de "falsa continuidade linear"17, para usar os termos do próprio autor.

Após atribuir a liderança da renovação arquitetônica, na década de 1930, ao grupo do Rio de Janeiro - mencionando seus estudos conscienciosos acerca do clima

15 MACHADO, L. G. Retrato da arte moderna do Brasil. São Paulo, Depto. de Cultura, 1947, p. 79-80. 16 lbid., p. 25.

17 Como já expusemos no capítulo anterior, Lourival, defendendo um trabalho crítico "cientifico", se opõe às elaborações baseadas numa "falsa continuidade linear" do desenvolvimento da nacionalidade ou da nação, que teriam em vista apenas a construção de uma "enorme unidade política" - propondo que, pelo contrário, a história seja entendida como "luta humana" e a formação da nacionalidade, como "construção sofrida e conquistada" (Ibid., p. 13). 
tropical e dos materiais de construção, de forma a "erguer a nova casa sobre a própria terra e dela ir tirando aos poucos uma fisionomia autêntica, natural" 18 -, Lourival reafirma o vínculo entre a arquitetura moderna e a tradição barroca:

(...) a nova arquitetura brasileira corresponde fielmente às necessidades, às condições e à mentalidade do país e que, entre ela e a autêntica arquitetura dos tempos da colônia, só vai a diferença imposta pela dimensão temporal em cuja função variou a sociedade transformando-se no tocante às condições de vida e ao alcance da técnica. Tão perfeita é a correspondência que, por vezes, o observador sente revelar-se no risco dos edifícios novos, não o cubismo europeu do mestre, mas a gratuidade e as ilusões de perspectivas que foram, em seu tempo, o apanágio do barroco, elemento histórico da arte no Brasil. ${ }^{19}$

Curiosamente, em relação à arquitetura, a sua leitura acaba assim por se aproximar daquela proposta pela "trama dominante", reproduzindo o discurso de Brazil builds. Enquanto a arquitetura moderna é naturalizada, posta como uma resultante "lógica" das preocupações com o clima tropical e continuação da autenticidade barroca, manifestações como o ecletismo não trazem nenhuma contribuição, no campo das artes e nem mesmo no da história. Ao encampar esta narrativa, Lourival parece ter sido bastante influenciado por Lucio Costa.

Embora não seja algo freqüente em seus escritos, em "Notas sobre a evolução do mobiliário luso-brasileiro", de 1939, Lucio Costa se detém no século XIX. Segundo o arquiteto, no Brasil, este período teria se caracterizado “pela vinda de D. João VI e da missão de artistas franceses, pela independência política e pelos primeiros sintomas de transformação econômica, com os tímidos ensaios de indústria e o surto da cultura do café em certas regiões do país - abrangendo também (...) boa parte do reinado de Pedro II" ${ }^{20}$. Seria também o período do surgimento das "modas ecléticas", às quais lentamente a "produção industrial" irá se contrapor:

Dessa época em diante, as várias modas ecléticas, artisticamente estéreis e já de fundo quase exclusivamente comercial, foram quebrando, aqui como em toda parte, a boa tradição, deformando o senso de medida e de conveniência. Ao passo que a produção industrial, a princípio tolhida e preocupada em moldar a sua maneira simples e precisa ao gosto elaborado e difuso de então (...) foi gradualmente deixando de lado os preconceitos e encontrando à própria custa o novo caminho, passando a produzir em série, e com grande economia de matéria, peças de uma técnica industrial

18 MACHADO, L. G. Retrato da arte moderna do Brasil. São Paulo, Depto. de Cultura, 1947, p. 82. 19 lbid., p. 82-83.

20 COSTA, L. "Notas sobre a evolução do mobiliário luso-brasileiro", 1939. In: XAVIER, Alberto [org]. Lucio Costa: sobre arquitetura. Porto Alegre, UniRitter, 2007, p. 105-106. 
impecável21, cuja elegância e pureza de linhas já revelavam um espírito diferente, despreocupado de imitar qualquer dos estilos anteriores, mas com estilo no sentido exato da expressão. ${ }^{22}$

Percebe-se que, para Costa, a "produção industrial" é dotada de vontade própria, e as buscas dos artistas (perdidos nessa época de grandes mudanças) não parecem ter nenhuma relação com os avanços técnicos contemporâneos. O próprio art nouveau, embora "bem-intencionado", é descrito como um movimento formalista que "dá as costas" à indústria.

\begin{abstract}
Infelizmente, também entre nós, os artistas e estetas não perceberam, desde logo, a significação profunda dessas primeiras manifestações sem compromissos da idade nova: uns, desgostosos, pensaram, com Ruskin, em reviver artificiosamente os processos rudimentares da produção regional e folclórica; outros, sem abandonarem as conveniências dos processos mecânicos, voltaram-se obstinadamente para o passado e se puseram a reproduzir, em grande escala e com incrível fidelidade, toda a gama dos estilos históricos; outros, enfim, muito bem intencionados, resolveram inventar de um momento para outro uma arte nova e, dando as costas à realidade, isto é, as características próprias da produção industrial, único ponto de partida possível, desandaram a criar curvas arbitrárias e formas sem consistência, como mero divertimento ou exercício de engenho, até cansar. ${ }^{23}$
\end{abstract}

Na perspectiva de Costa, as artes decorativas são desvalorizadas; o seu caráter artesanal (caracterizado por Costa, alguns anos mais tarde como sendo de "um retardado ruskinismo" ${ }^{24}$ ) deixa, portanto, de ser considerado ou aproveitado na reflexão acerca da produção contemporânea - diferentemente do que acontecia, por exemplo, em "Documentação necessária", texto em que a mão de obra artesanal portuguesa, com sua "saúde plástica perfeita", aparecia como síntese da boa tradição da arquitetura brasileira, vinculada diretamente à arquitetura moderna ${ }^{25}$.

Já na década de 1950, em "Muita construção, alguma arquitetura e um milagre", Costa irá delimitar temporalmente o momento de "quebra definitiva" da boa tradição: a "era republicana" ${ }^{26}$. Em determinado momento da análise, o texto

21 O autor está se referindo a peças como as de Michel Thonet (1796-1871), austríaco que, na década de 1860, criou uma linha de móveis fabricados em madeira curvada a fogo, produzidos em série e vendidos a preços relativamente baixos.

22 COSTA, L. "Notas sobre a evolução do mobiliário luso-brasileiro", 1939. In: XAVIER, Alberto [org]. Lucio Costa: sobre arquitetura. Porto Alegre, UniRitter, 2007, p. 106.

23 Ibid., p. 108. Grifo nosso.

24 Idem. "Muita construção, alguma arquitetura e um milagre"/ "Depoimento de um arquiteto carioca", 1951. In: XAVIER, Alberto [org]. Op. cit., p. 185-186.

25 Idem. "Documentação necessária", 1937. In: XAVIER, Alberto [org]. Op. cit, p. 86-94.

26 Agora, Costa passa considerar válido não apenas o passado luso-brasileiro mas também a "fecunda experiência neoclássica" dos discípulos do arquiteto neoclássico Grandjean de Montigny (1776-1850), integrante da Missão Francesa. 
- que seria uma tentativa de "precisar melhor os antecedentes do movimento restrito e autônomo, mas persistente, da nova [moderna] arquitetura" ${ }^{27}$ - voltase ao Rio de Janeiro das primeiras décadas do século XX e aos movimentos de "feição erudita": o "apurado e sóbrio art nouveau" e os "estilos históricos", que incluem o gótico, o renascentista italiano ou francês, e as versões Beaux-Arts do Luís XV e XVI. Menciona também o neocolonial e o "extravagante" marajoara, "derradeira manifestação plástica inconseqüente e inorgânica, filiada ainda às concepções anteriores do art nouveau e de $\operatorname{Virzi}^{28}$ (...) pretensamente inspirado na arte puríssima da cerâmica indígena"29.

Todas essas manifestações são, para Costa, destituídas de qualquer sentido "orgânico-funcional" 30 e, portanto, de qualquer "significação arquitetônica". Para além do tom de rememoração que o arquiteto confere ao seu relato ${ }^{31}$, a atenção

27 COSTA, L. "Muita construção, alguma arquitetura e um milagre"/ "Depoimento de um arquiteto carioca", 1951. In: XAVIER, Alberto [org]. Lucio Costa: sobre arquitetura. Porto Alegre, UniRitter, 2007, p. 174.

280 arquiteto italiano Antônio Virzi (1882-1954) chega ao Rio de Janeiro em 1910. Procurado por uma burguesia ansiosa em demonstrar publicamente a sua prosperidade, seus extravagantes projetos inicialmente em art nouveau, e depois em art déco - contrapunham-se ao "comportado" e acadêmico ecletismo da época. Segundo Alberto Taveira, Virzi foi um "arauto dos novos tempos arquitetônicos no Brasil": em seus projetos, desenhava todos os detalhes - entendendo a arquitetura como síntese das artes e o arquiteto como artista total; também se dedicará a novos programas arquitetônicos, projetando não apenas dezenas de residências, mas também cinemas e fábricas (TAVEIRA, A. "Fogos de artifício à luz do dia: a arquitetura de Antonio Virzi no Rio de Janeiro". In: Revista Cidade Nova, no. 1, 2007, p. 163-173). Uma dessas residências, situada à Avenida Atlântica, chamará a atenção de Motta quando de sua visita ao Rio para pesquisar o art nouveau. Motta chega mesmo a pensar que o arquiteto fosse espanhol, por identificar uma proximidade entre as suas obras e aquelas do "grupo de Gaudi" (Cf. Anexo, Documento 23).

29 COSTA, L. Op.cit., p. 186.

30 Em outro texto da mesma época, "Considerações sobre arte contemporânea", Costa define "orgânico funcional" como um conceito "cujo ponto de partida é a satisfação das determinações de natureza funcional, desenvolvendo-se a obra como um organismo vivo onde a expressão arquitetônica do todo depende de um rigoroso processo de seleção plástica das partes que o constituem e do modo como são entrosadas". O "modelo histórico mais significativo" deste conceito seria a arquitetura gótica, que, do ponto de vista da "expressão plástica", estaria associada a uma "concepção formal dinâmica". O "orgânico-funcional" historicamente seria complementado pelo conceito "plástico-ideal", "intenção preconcebida de ordenar racionalmente as conveniências de natureza funcional, visando à obtenção de formas livres ou geométricas ideais, ou seja, plasticamente puras"; a arquitetura clássica seria a "manifestação mais credenciada" desse segundo conceito, associado ainda a uma "concepção estática da forma". Segundo Costa, a arte moderna mesclaria os dois conceitos, sintetizando o "orgânico-funcional"e o "plástico-ideal" (Idem. "Considerações sobre arte contemporânea", 1952. In: XAVIER, Alberto [org]. Lucio Costa: sobre arquitetura. Porto Alegre, UniRitter, 2007, p. 204-205).

31 Lucio Costa admite, não apenas neste texto mas em diversos outros momentos, ter uma relação afetiva com o Rio de Janeiro das primeiras décadas do século XX - o que não impede que ele mantenha, por décadas, uma posição de intransigência em relação ao valor do ecletismo e outras manifestações do período. Sendo o "valor plástico", mesmo nas construções do passado, sinônimo de "valor arquitetônico", fica o "valor histórico" relegado a um segundo plano - é o que aconteceu no caso célebre do 
dedicada a esta "feira de cenários arquitetônicos improvisados" parece ter uma função principal: reforçar o caráter revolucionário (e não mais evolutivo, como em "Documentação necessária") que o autor passa a associar à arquitetura moderna brasileira, e negar qualquer possibilidade de leitura dos "estilos" como antecedentes do moderno.

O desenvolvimento da arquitetura brasileira ou (...) os fatos relacionados com a arquitetura no Brasil nestes últimos cinqüenta anos, não se apresentam concatenados num processo lógico de sentido evolutivo; assinalam apenas uma sucessão desconexa de episódios contraditórios, justapostos ou simultâneos, mas sempre destituídos de maior significação e, como tal, não constituindo, de modo algum, estágios preparatórios para o que haveria de ocorrer. ${ }^{32}$

Frente a tais posições de desvalorização do período republicano, e especificamente do art nouveau, Motta irá propor um outro caminho. Contrariando as posições de autores reconhecidos, irá retomar as manifestações do período, deixando de avaliá-las em termos de "autenticidade", "valor artístico", "valor plástico" etc. 0 sentido de seu estudo é outro:

Num país onde a aceitação de certos "modismos" ainda garante a euforia dos "movimentos de arte" ${ }^{33}$, a revisão histórica é sempre uma perspectiva de domínio sobre as nossas tendências e, conseqüentemente, sobre a nossa possibilidade criadora. ${ }^{34}$

Fazer a revisão histórica (que Motta irá também chamar de revisão crítica) da história da arte nacional como "perspectiva de domínio sobre as nossas tendências", ou seja, como recurso para a criação artística do presente ou do futuro, é sem dúvida dar prosseguimento à tradicionalização de Mário de Andrade - que, não custa relembrar, queria o passado como "valor agente pesando no mecanismo brasileiro" ${ }^{35}$.

Palacete Monroe, pavilhão do Brasil na Exposição Internacional de St Louis. O pavilhão, remontado no Rio de Janeiro em 1905, é demolido em 1975, após intenso debate dentre o Instituto Histórico e geográfico Brasileiro e o DPHAN; nesse debate, Costa, parecerista do DPHAN, mostra-se contrário à preservação do imóvel, tanto por considerar o ecletismo como uma "mentira" (ou um "hiato" na História da Arte), como pela localização do Palacete - para o arquiteto, impunha-se o "desafogo" urbano da área onde estava implantado o imóvel (sobre esse caso, ver o artigo de SANTOS, C. R. "Problema mal posto, problema reposto". In: NOBRE, A. L, KAMITA, J. LEONÍDIO, O. e CONDURU, R (org). Lucio Costa: um modo de ser moderno. São Paulo, Cosacnaify, 2004, p. 132-145).

32 COSTA, L. "Muita construção, alguma arquitetura e um milagre"/ "Depoimento de um arquiteto carioca", 1951. In: XAVIER, Alberto [org]. Op. cit., p. 174.

33 Podemos supor que aqui Motta está se referindo a movimentos como concretismo e arte abstrata, vistos por ele e por Habitat com desconfiança, por sua defesa do "novo" - o manifesto Ruptura, de 1952, afirma: "(...) a história deu um salto qualitativo. Não há mais continuidade".

34 MOTTA, F. Contribuição ao estudo do art nouveau no Brasil. Tese (cátedra). São Paulo, FAUUSP, 1957, p. 7. Grifo nosso.

35 ANDRADE, M. "Assim falou o papa do futurismo", 1925. In: LOPEZ, Telê Porto A.[org]. Mário de Andrade: entrevistas e depoimentos. São Paulo, TA Queiroz, 1983, p. 18. 


\title{
3.2. O art nouveau por Flávio Motta Um movimento republicano e paulista
}

Inicialmente, o interesse de Motta pelo art nouveau surge como reação às recentes demolições de imóveis construídos nesse estilo, na cidade de São Paulo. Como vimos, as páginas de Habitat abrem espaço uma "campanha" de salvação do floreal paulistano, chegando mesmo a propor a instalação de um museu em um destes imóveis.

Os exemplares do art nouveau (...) estão condenados a desaparecer dentro de poucos anos. (...) Hoje, o concreto, nos prédios de apartamentos, desfigurou completamente o aspecto das antigas ruas e destruiu o art nouveau que era o encanto das velhas residências. (...) Somos dos que pensam que o Patrimônio deveria "tombar" (garantir) alguns exemplares mais interessantes, já que não pode evitar que a maioria seja tragada pela avalanche imobiliária. ${ }^{36}$

Além da "picareta de sua majestade o corretor de imóveis", um outro elemento estaria contribuindo para a extinção do art nouveau: a insistência dos "historiógrafos" em "desdobrar a história da arte brasileira exclusivamente na pauta do barroco".

\begin{abstract}
A tal ponto chegou este desvio que a Diretoria do Patrimônio Histórico e Artístico Nacional está, hoje em dia, transformada em órgão especializado na preservação e estudo dos monumentos barroco-coloniais. Em São Paulo, como restam apenas poucos exemplares de arquiteturas dos séculos XVI, XVII e XVIII a Diretoria tornou-se, por conseqüência, um órgão de ação restrita. ${ }^{37}$
\end{abstract}

Com o estudo do art nouveau o autor pretende chamar a atenção para a existência de outras contribuições, outros estilos e movimentos, na história da arte brasileira. Historicamente, o art nouveau é expressão da riqueza provinda da cafeicultura, da industrialização crescente, da abolição da escravatura e da presença marcante dos imigrantes europeus.

\begin{abstract}
A Revolução Industrial convulsionou tão profundamente o clima de idéias e reivindicações sociais na Inglaterra, durante o século XIX, que os artistas e intelectuais não ficaram indiferentes a esse movimento. Como a Inglaterra, com o seu comércio e o predomínio dos mares, transmitia ao Novo Mundo conseqüências dessas transformações, não poderia o Brasil escapar, com sua vida econômica incerta, às naturais injunções desse processo. A queda do Império, a própria República, a libertação dos escravos foram fatores de maior aproximação com os ingleses (...) A abolição da escravatura trouxe para cá a imigração européia que, por sua vez fomentou certos hábitos urbanos, atraindo pintores e construtores. Além do movimento imigratório que crescia a passos largos (...) criaram-se novas possibilidades de mercado e de
\end{abstract}

36 MOTTA, F. "São Paulo e o art nouveau". In: Revista Habitat, no. 10, 1953, p. 3.

37 Ibidem. 
comércio. A indústria cresceu com a abertura de novas ferrovias, instalações hidrelétricas, perturbando só velhos hábitos da mentalidade colonial e ruralista. (...) Recebendo costumes e processos amadurecidos em outras terras, o país experimentou verdadeiro trauma na sua vida cultural. Herdava parcela de uma experiência histórica para mesclar com outras etapas da sua ainda informe transição do Império à República, do braço escravo ao braço livre, da atividade rural à industrial, do poder central ao poder federativo, do Brasil-colônia ao Brasil independente. Todas essas transformações, na imensidão da terra se diluíam, para ficarmos com os Brasis de muitas idades, do exemplo de Oliveira Viana. ${ }^{38}$

As províncias, em especial, vivem essas mudanças com intensidade:

(...) a província se desenvolveu. Principalmente aquelas bafejadas por condições econômicas favoráveis. Fundaram-se bancos; cresceram as cidades, impulsionadas pela indústria, pela imigração, pela riqueza do café e da borracha; fortaleceram-se princípios democráticos, no trato direto entre os homens, na troca de opiniões; estimulouse a educação em novas bases. ${ }^{39}$

São Paulo, especificamente, conhece um grande desenvolvimento nesta época, permitindo que Motta possa tratar do art nouveau como um movimento primordialmente paulista ${ }^{40}$, ligado a um contexto específico - no qual representava "o coroamento espiritual na vida daquela gente que se enriquecia com o café e se iniciava na vida industrial".

Assim, ao longo do trabalho, Motta vai mostrando como o estilo se fez presente não apenas nas residências de bairros paulistanos (como Vila Buarque, Campos Elíseos, Bela Vista, Cambuci), mas em edifícios escolares e teatros; não apenas na cidade de São Paulo, mas em todo o Estado, acompanhando "a valorização do café no seu roteiro, desde o Vale do Paraíba, até Ribeirão Preto, nas residências das fazendas, nos coretos dos jardins públicos, nas estações de estradas de ferro, nos quartéis e nos grupos escolares" ${ }^{41}$. Influencia os artistas gráficos (de revistas como Careta, Fon-Fon, Vida Moderna, O Pirralho), os artesãos do Liceu, e os arquitetos (dentre os quais os já citados Ekman e Dubugras). É adotado não apenas pelas elites, por industriais e fazendeiros, mas pelo "próprio povo"42.

\footnotetext{
38 MOTTA, F. Contribuição ao estudo do art nouveau no Brasil. São Paulo, FAUUSP (Cátedra), 1957, p. 27. 
Delineia-se assim, com a recuperação do art nouveau, um outro horizonte para a construção da história da arquitetura e da arte brasileira - que passa a incluir as manifestações oriundas de "novas" localidades, como São Paulo (usualmente reconhecida apenas pontualmente, por seus poucos - e pobres - exemplares da arquitetura dita bandeirista), e manifestações do período da Primeira República (que, como vimos, eram geralmente deixadas de lado pelos historiógrafos do moderno, preocupados com o resgate do período colonial).

\section{Origem e transição: art nouveau e movimento moderno}

Um elemento importante na construção desse novo horizonte histórico-crítico é a busca pelas relações de continuidade entre os séculos XIX e XX. Como afirma Motta, "no caso do art nouveau, ainda temos muito a desvendar, inclusive para maior compreensão de um ponto obscuro do desenvolvimento artístico brasileiro, isto é, o período que antecede o Movimento Modernista"43. Para o autor, o estudo do passado é orientado pela preocupação com o movimento moderno, e num primeiro momento o art nouveau aparece, também no Brasil, como uma de suas origens.

O autor vai buscar esta noção de origem na historiografia da arquitetura e do urbanismo modernos, em especial no crítico e historiador da arte inglês Nikolaus Pevsner, citado por Motta nos três textos e referência constante em seu trabaIho crítico ${ }^{44}$. Para Pevsner, o art nouveau é uma das três principais origens do moderno: "o Movimento Moderno não nasceu de uma só raiz (...) uma de suas fontes principais foi Morris e as Artes e Ofícios; uma outra foi a Arte Nova. As obras dos engenheiros de século XIX são a terceira fonte do estilo atual" 45 . Embora considerando a "Arte Nova" como "a mais controversa" entre as "origens da arquitetura moderna e do design", nem por isso o autor deixa de identificar nesse movimento certas características fundamentais que o colocariam entre as raízes do modernismo e do próprio século $\mathrm{XX}$ - sendo a principal delas a recusa

43 MOTTA, Flávio. Contribuição ao estudo do art nouveau no Brasil. Tese (cátedra). São Paulo, FAUUSP, 1957, p. 7.

44 O primeiro livro de Pevsner, Pioneiros do desenho moderno, de 1936, é considerado por Motta uma obra fundamental, que "ressalta a importância do movimento [art nouveau] para a melhor compreensão da arte no século XX" (MOTTA, F. "Art nouveau: um estilo entre a flor e a máquina". In:

Cadernos Brasileiros, v. 28, n. 2, mar/ abr 1965, p. 56). Além de Pioneiros... dentre os principais livros do crítico e historiador podemos citar Panorama da arquitetura européia (de 1942), e Origens da arquitetura moderna e do design (da década de 1960), que são defesas do movimento moderno em arquitetura e em especial do moderno "racionalista" dos alemães da Werkbund e Bauhaus - em oposição a Le Corbusier e aos "brasileiros" (como diz o próprio Pevsner).

45 PEVSNER, N. Pioneiros do desenho moderno. Lisboa, Ulissea, 1962, p. 107. 
em aceitar qualquer ligação com o passado, a necessidade de "romper as cadeias do historicismo" 46 .

$\mathrm{Na}$ retomada dos fundamentos históricos do art nouveau europeu, o trabalho de Motta baseia-se muito em Pevsner. Irá fazer um percurso introdutório pelo desenvolvimento do art nouveau em países como França, Alemanha, Áustria, Itália, Bélgica e Inglaterra; os dois últimos terão especial importância no relato. O surgimento do art nouveau teria se dado na Bélgica e, dali, se espalhado por toda a Europa. Os arquitetos - dentre os quais os precursores Victor Horta (18611947) e Henry Van de Velde (1863-1957) - ocupam papel de destaque, exercendo um papel de coordenação das demais manifestações plásticas. Motta, citando Pevsner, considerará Horta como "o primeiro e ao mesmo tempo o mais puro exemplo do art nouveau"47; já a obra de Van de Velde teria grande influência para além das fronteiras da Bélgica, em especial na Alemanha, tendo continuidade no movimento moderno ${ }^{48}$.

A influência inglesa é também destacada por Motta, que vê uma "passagem suave" entre o floreal e seus precursores do pré-rafaelismo e do arts and crafts, como John Ruskin (1819-1900), Dante Gabriel Rosetti (1828-1882) e William Morris (1834-1896) ${ }^{49}$. O floreal inglês, em seu período de formação, teve inicialmente "veleidades nacionalistas"; a sua "confiança na capacidade criadora do indivíduo" resulta em práticas que priorizam o conhecimento da natureza, a investigação sensível, o respeito à atividade manual - "à semelhança dos primeiros mestres do Renascimento" ${ }^{50}$. Posteriormente, com o advento das Exposições Universais, o movimento adquire um sentido de "congraçamento das artes e da indústria, num plano internacional", sentido controverso (já que, para alguns autores, significaria uma degeneração das idéias de Morris e a exacerbação do "comercialismo" inglês).

À noção de origem, Pevsner e outros autores retomados por Motta irão aliar a noção de transição, destacando, assim, a ligação deste estilo como expressão de uma época de crises e grandes mudanças, como foi a virada do século XIX para o XX na Europa. Enquanto Pevsner afirma que o art nouveau foi "um estilo de transição entre o estilo vitoriano e o movimento moderno", o crítico brasileiro

46 PEVSNER, N. Origens da arquitetura moderna e do design. São Paulo, Martins Fontes, 1981, p. 50.

47 MOTTA, F. "São Paulo e o art nouveau". In: Revista Habitat, n.10, 1953, p. 4.

48 Id. Contribuição ao estudo do art nouveau no Brasil. Tese (cátedra). São Paulo, FAUUSP, 1957, p. 22.

49 Id. "São Paulo e o art nouveau". In: Revista Habitat, n.10, 1953, p. 4.

50 ld. Contribuição ao estudo do art nouveau no Brasil. Tese (cátedra). São Paulo, FAUUSP, 1957, p. 14. 
Araújo Viana ${ }^{51}$, também referência constante nos trabalhos de Motta sobre o art nouveau, identifica o século XIX como preparação para o que viria depois:

O século [XIX] vai expirar sem o legado de uma arquitetura exclusiva. Será considerado para os arquitetos como época de transição, entregue ao estudo das obras de todos os tempos e de todos os países, caracterizadas pela imitação eclética ou cosmopolita, adaptada às condições climatéricas de cada região, segundo o progresso da ciência e da indústria. Foi como uma preparação para a arquitetura do século $X X{ }^{52}$

A transição é, assim, uma noção que vai permear todo o trabalho de Motta sobre o art nouveau. O movimento é reconstruído e conformado a partir das análises das várias transições nele contidas: do ornamento para a construção, do artesanato para a indústria, dos estilos historicistas para um "estilo de transição" 53, a transição dos estilos para o movimento moderno - que em oposição ao historicismo dos "estilos" e às incertezas do art nouveau, representaria a defesa de uma arte e uma arquitetura conscientes de sua própria época histórica.

\section{Um estilo sem estilo}

Nesta perspectiva, Motta preocupa-se em situar o art nouveau, "movimento artístico fin de siècle", dentro da história da arte. A partir de Lionello Venturi, identifica nos escritos do neoclássico J. Winckelmann (1717-1768) "uma preocupação normativa de estilo", e a "procura de uma nova ordem, de uma linguagem que visse reduzir a expressões claras, positivas e moduladas, os ideais do mundo contemporâneo" 54 .

Dentro desta procura, no século XIX, surgem os neos - como o Neogótico e o Neoclássico. Segundo Motta, são eles "recursos de emergência", na medida em que dependem do passado, de "normas e inspirações emprestados de outras épocas" como premissas para a atividade criadora. Teriam surgido, em grande parte, porque em sua época "o processo de industrialização ainda não oferecia elementos para uma renovação integral de todas as manifestações artísticas" 55 .

51 Ernesto da Cunha de Araújo Viana foi professor da Escola Nacional de Belas Artes, no Rio de Janeiro, e um dos integrantes do movimento neocolonial - ao lado de José Mariano Filho e Lúcio Costa, entre outros intelectuais e artistas. Para Motta, "foi um dos críticos mais completos da época, tratando de arquitetura, escultura, pintura, história e estética. Nos seus trabalhos (...) reúne documentação para a história das artes plásticas no Brasil (...) como crítico, parecia informado e demonstrava certa reserva pelo abuso dos neos, da orientação acadêmica". O crítico também "manifestava (...) na passagem do século, a consciência do caráter eclético e acadêmico da nossa arquitetura e vislumbrava uma perspectiva para a harmonia entre as fórmulas positivas da ciência e os ideais das artes do desenho, embora tendo a decoração e ornamento como traço de união" (in MOTTA, F. Contribuição ao estudo do art nouveau no Brasil. Tese (cátedra). São Paulo, FAUUSP, 1957, p. 33).

52 Ibid., p. 33.

53 Id. "São Paulo e o art nouveau". In: Revista Habitat, n.10, 1953, p. 6.

54 Id. Contribuição ao estudo do art nouveau no Brasil. Tese (cátedra). São Paulo, FAUUSP, 1957, p. 8. 55 lbid. 
O nascimento do art nouveau se dá exatamente nesse contexto - expressão da busca ansiosa por uma manifestação de "poder criador" independente: independente em relação ao passado, do qual não pretendia fazer cópias servis, e independente também dos métodos e normas rígidos do ensino acadêmico - Motta ressalta sempre o fato do movimento ter como ideal a livre expansão da personalidade do artista ${ }^{56}$, citando Oscar Wilde em francês: "La personnalité: voilá ce qui nous sauverá" 57 .

Ainda assim, entretanto, o art nouveau não consegue prescindir da preocupação estilística: mesmo seus defensores irão enxergá-lo como "o verdadeiro estilo do século" 58 . Em seu esforço de conciliação das artes - principalmente por meio das artes decorativas - dentro de uma "unidade estilística que não vingou", o art nouveau expressa todas as contradições da época em que surge. Motta prefere, então, entendê-lo como "um estilo sem estilo":

\begin{abstract}
O que nós importamos [no Brasil] foi "um estilo sem estilo", porque era um estilo que não copiava os outros; o que nós procuramos foi um "estilo de transição", entre o "historicismo" e o "modernismo"; foi um movimento que incentivou as faculdades inventivas individuais, estimulou o artesanato e as artes aplicadas, mas não compreendeu com exatidão as verdadeiras possibilidades da máquina como instrumento da cultura. O seu grande mérito consistiu em chamar a atenção sobre as artes aplicadas e romper com fórmulas cansadas. ${ }^{59}$
\end{abstract}

Como se vê, esse entendimento do art nouveau já aponta para o século XX; mas o raciocínio de Motta, iniciado nos textos da década de 1950 só seria completado na década seguinte. Em "Art nouveau: um estilo entre a flor e a máquina", de 1965, Motta irá definir estilo como "anseio de unificar o modus faciendi e vivendi de uma cultura, de uma época", opondo a essa preocupação típica dos homens do século XIX "a luta contra a concepção de estilo tomado como unidade imposta através de regras, normas e legislações incapazes de traduzir a dinâmica criadora do homem na História e na sociedade em que vive" 60 - luta que, para o autor, seria característica do movimento moderno.

56 Segundo Luiz Scatollini, diretor do Liceu, "o art nouveau permitia muita expansão da personalidade de cada um. Assim, havia entusiasmo, mas (...) uns faziam com mais talento e outros faziam coisas horríveis. Era um estilo que dependia do valor de cada um, quase não se tinha de onde copiar" (MOTTA, F. "São Paulo e o art nouveau". In: Revista Habitat, n.10, 1953, p. 6.). Essa característica do art nouveau acabará por se constituir, segundo Motta, em uma de suas limitações (como veremos mais adiante).

57 Ibid.

58 Id. Contribuição ao estudo do art nouveau no Brasil. Tese (cátedra). São Paulo, FAUUSP, 1957, p. 8.

59 ld. "São Paulo e o art nouveau". In: Revista Habitat, n.10, 1953, p. 7.

60 Id. "Art nouveau: um estilo entre a flor e a máquina". In: Cadernos Brasileiros, v. 28, n. 2, mar/ abr 1965, p. 55. 
Essa superação dos estilos, entretanto, não impede que Motta reconheça a sua validade - assim como a da moda e do gosto - para o desenvolvimento da história da arte e para o trabalho do crítico ou historiador. Mesmo quando limitadas e insuficientes, fugazes ou superficiais, as manifestações da cultura, se em conformidade com a "dinâmica social", permitiriam "caracterizar sintomas, ou ainda, avaliar as possibilidades de transformações mais profundas nas áreas de convívio"61.

\section{Ornamento e construção}

Segundo Motta, "Loos considerava a ornamentação, no mundo moderno, como expressão bárbara, erótica, degenerada e delinqüente" ${ }^{62}$. Motta, além de descrever a visão que o arquiteto austríaco Adolf Loos (1870-1933) tinha do ornamento, coloca-a em questão. Propõe uma análise que procura situar o ornamento historicamente, identificando nele um papel conciliador, unificador, um "meio termo entre aquilo que parecia artifício - a técnica, vontade de forma imposta à realidade - e aquilo que se manifestava no homem, como necessidade psicológica e emocional de espontânea comunhão com a natureza"63. Segundo Motta, em determinados momentos históricos (como durante o Renascimento, por exemplo), arte e ciência encontravam-se "unidas a uma inspiração comum"; o ornamento era, então, pleno de sentido e justificava-se como a expressão una de uma dualidade básica entre razão e sensação.

O desenvolvimento da ciência e da técnica, entretanto, passa a colocar a existência de uma "segunda natureza, rígida e agressiva, diante da primeira, fonte perene de inspiração" 64 - processo que culminou na Revolução Industrial. Esta separação, como não poderia deixar de ser, instaura uma grande crise também na produção artística, influindo mesmo no significado e função do ornamento que, cindido, deixa de ser expressão da "integração homem-mundo"65 e passa, em momentos como o do arts and crafts e do art nouveau, a representar a defesa do sensível e a proximidade com a natureza, em uma época de transição.

Contrapondo-se a críticos como Giedion, que teriam dado "maior ênfase à renovação dos processos técnicos (...) de tal maneira a considerar o engenheiro o verdadeiro arquiteto do século XIX", Motta considera que o aprofundamento dos

61 MOTTA, F. "Art nouveau: um estilo entre a flor e a máquina". In: Cadernos Brasileiros, v. 28, n. 2, mar/ abr 1965, p. 55.

62 Id. Contribuição ao estudo do art nouveau no Brasil. Tese (cátedra). São Paulo, FAUUSP, 1957, p. 25.

63 Ibid., p. 09.

64 lbid., p. 09.

65 Ibid., p. 10. 
estudos acerca de movimentos como o arts and crafts e o art nouveau assinalaria "a presença de um verdadeiro movimento intermediário entre o mundo da construção - vinculado intimamente às conquistas técnicas, científicas e à Revolução Industrial - e o mundo da 'coisa subordinada à outra e com essa em harmonia', o que vale dizer, da arte preocupada com a condição humana, com o ambiente, com a paisagem, com atmosfera" ${ }^{66}$.

"As distâncias entre a construção e a pintura não são pronunciadas, como quis Giedion"67: para Motta, a pintura, e em especial a do Impressionismo, vem desempenhar um papel importante nesta transição entre ornamento e construção ${ }^{68}$. Partindo de uma "atitude de simpatia, de procura uma integração espontânea com a natureza" e da "emoção direta diante da paisagem, do ótico"69, os impressionistas irão caminhar cada vez mais em direção aos problemas construtivos, como se pode ver pela obra de Paul Cézanne (1839-1906):

Quando Cézanne enfrentou os problemas construtivos, atenuava o caráter ornamental da pintura, ao mesmo tempo que aproximava sua obra da expressão arquitetônica. À medida que assim procede, afasta-se daquelas tradições artesanais onde o ornamento era a melhor forma livre de expressão do artesão e a meio passo do gosto popular. ${ }^{70}$

Com uma "consciência cada vez maior da função e da natureza do ornamento"71, o processo que surge na pintura começa também a se manifestar na arquitetura, na obra dos arquitetos belgas e em especial de Van de Velde - que, ao unir soluções construtivas e formas curvilíneas (antes presentes apenas nos ornamentos) e apelando às soluções racionais, conduz a construção para as "inspirações primeiras do ornamento"72. O desenvolvimento desse processo de unificação iniciado

66 MOTTA, F. "Art nouveau: um estilo entre a flor e a máquina". In: Cadernos Brasileiros, v. 28, n. 2, mar/ abr 1965, p. 59.

67 lbid.

68 Esta relação entre ornamento e construção, desenvolvida por Motta, é tomada do historiador da arte norueguês Tschudi Madsen (1923-2007), pioneiro no redescobrimento do art nouveau nos anos 1950; aluno de Pevsner, sua tese de PhD, Sources of art nouveau, é uma das referências mais constantes ao longo da Contribuição ao estudo do art nouveau no Brasil.

69 MOTTA, F. Contribuição ao estudo do art nouveau no Brasil. Tese (cátedra). São Paulo, FAUUSP, 1957, p. 35.

70 lbid., p. 46.

$71 \mathrm{lbid}$., p. 34. Diferentemente de Motta, que procura colocar os diferentes movimentos "renovadores" do fim do século XIX e início do XX em relação entre si, Pevsner encontra uma "diferença irreconciliável" entre o Impressionismo e o arts and crafts; enquanto este seria uma expressão "daquilo que é definitivo e essencial (...) uma fé renovada na mensagem social da arte", aquele teria uma "concepção da arte como uma expressão de efeitos momentâneos de superfície (...) a filosofia da arte pela arte".

72 lbid., p. 46. 
com os arquitetos europeus - processo que dependia não apenas da consciência de artistas e arquitetos, mas de um "necessário desenvolvimento técnico, social, cultural" mais amplo - só alcança a sua plenitude com a arquitetura moderna.

Para Motta, seria Lucio Costa quem definiria melhor "o campo específico da arquitetura como construção - 'construção concebida com a intenção de ordenar plasticamente o espaço, em função de uma determinada época, de um determinado meio, de uma determinada técnica e de um determinado programa'"73. 0 sentido originário do ornamento é assim recuperado, já que a "intenção plástica" (a subjetividade do artista) passa a ser indissociável da construção (o elemento objetivo, material), resultando numa arte e arquitetura "plásticas" mas também histórica e socialmente determinadas ${ }^{74}$.

\section{A arte entre $\mathrm{o}$ artesanato e $\mathrm{a}$ indústria}

Em estreita ligação com a discussão ornamento-construção, está aquela da dualidade entre artesanato e indústria, ou a transição do artesanato para a indústria. É uma questão que Motta propõe abordar de duas maneiras: no terreno específico da expressão artística (a "polêmica forma-conteúdo"), e no terreno das transformações dos meios de produção ${ }^{75}$.

73 COSTA, L. "Considerações sobre arte contemporânea". In: Cadernos de Cultura do MEC, 1952 apud MOTTA, F. Contribuição ao estudo do art nouveau no Brasil. Tese (cátedra). São Paulo, FAUUSP, 1957, p. 35.

74 Lucio Costa é uma referência recorrente em Contribuição...., e seu texto "Considerações sobre arte contemporânea", publicado em 1952, é especialmente importante - nele, Costa mostra-se preocupado em formular uma ligação entre a intenção plástica e o sentido social na arquitetura ou, em outras palavras, tentando encontrar uma solução para o problema da ligação entre a arte e o povo. A celebre definição de arquitetura, citada por Motta, reflete essa preocupação na medida em que a "intenção plástica" tem posição central, mas é posta em função da "época", da "técnica", do "meio" e do "programa" (todos eles fatores de "condicionamento" social da arquitetura, de relação entre artista e sociedade). A preocupação de Costa - que expressa o momento histórico e o acirramento das contradições em que estavam imersos arquitetos e artistas modernos, entre a defesa do princípio da arquitetura como arte social e a sua posição de "ilha em um mar de barracos" - é desenvolvida nesse mesmo texto, com a proposição de uma "nova conceituação" para a arte, "capaz de desfazer o pseudodilema que preocupa a tantos críticos e artistas contemporâneos (...) o da gratuidade ou militância da arte": a "arte pela arte com função social". Fazendo uma distinção entre "origem" e "essência" da obra de arte - a primeira indubitavelmente "interessada", e a segunda "manifestação isenta" - Costa propõe que se procure uma síntese entre esses dois pólos. (COSTA, L. "Considerações sobre arte contemporânea", 1952. In: XAVIER, Alberto [org]. Lucio Costa: sobre arquitetura. Porto Alegre, UniRitter, 2007, p. 216-217).

75 MOTTA, Flávio. Contribuição ao estudo do art nouveau no Brasil. Tese (cátedra). São Paulo, FAUUSP, 1957, p. 9. 
Retomando as lições do artista francês Eugène Grasset (1841-1917)76, a partir das anotações de seu discípulo, o brasileiro Visconti, Motta explica que no art nouveau forma e conteúdo são consideradas duas coisas distintas. A forma seria o resultado de um pensamento lógico, quase matemático, e o conteúdo seria a própria natureza, "livro de arte ornamental que precisa ser consultado"77. Entretanto, é interessante notar que Grasset, mesmo separando os fatores construtivos dos ornamentais e apontando a decoração como um desejo de esconder a construção, defendia o uso (ou função) e a matéria como os dois fatores fundamentais para a definição da forma dos objetos, colocando limites à representação exata da natureza ("limite que não deve ser de maneira nenhuma destruído") - apontando assim, ainda que de forma preliminar, uma ligação intrínseca entre forma e conteúdo, ou entre a representação e o objeto representado. O art nouveau procuraria a reaproximação entre as formas de inspiração naturalista e a organização geométrica, e um "convívio maior entre ornamento e construção", desenvolvimento do qual já tratamos anteriormente.

Para Motta, é apenas no século XX que este problema irá ganhar teorizações mais claras, a partir do momento em que se começa a procurar uma síntese entre forma e conteúdo; o ornamento agora pode ser abandonado, pois o "sentido orgânico e naturalista" que tinha (em movimentos como o art nouveau, por exemplo) é superado em favor do sentido "orgânico funcional", que passa a abranger toda a construção. $\mathrm{O}$ autor novamente cita o arquiteto carioca:

É na fusão desses dois conceitos (ideal e funcional), quando o jogo das formas livremente delineadas ou geometricamente definidas se processa espontâneo e intencional (...) - que se escondem a sedução e as possibilidades virtuais ilimitadas da arquitetura moderna. ${ }^{78}$

Em relação à transformação dos meios de produção, o fim do século XIX vivia o "divórcio das artes (arquitetura, pintura, escultura, artes aplicadas)" e uma gran-

76 Admirador da arte egípcia e japonesa, Grasset trabalhou inicialmente como pintor e escultor na cidade de Lausanne. Em 1871 muda-se para Paris e dedica-se às artes decorativas, desenhando mobiliário, padrões de tecidos, tapeçarias, cerâmicas e jóias. A partir do fim da década de 1870 passa também a trabalhar como artista gráfico e cria alguns dos mais célebres pôsteres do art nouveau. No final do século XIX torna-se professor da École Guérin; entre seus discípulos estão Augusto Giacometti (1877-1947), Paul Berthon (1872-1909), Otto Ernst Schmidt (1862-1926), além dos brasileiros Eliseu Visconti e Lucílio de Albuquerque (1877-1939).

77 Expressão que Motta toma de Tschudi Madsen.

78 COSTA, L. "Considerações sobre arte contemporânea". Rio de Janiero, MÊS, 1952, p. 7 apud MOTTA, F. Contribuição ao estudo do art nouveau no Brasil. Tese (cátedra). São Paulo, FAUUSP, 1957, p. 10. 
de crise do modo de produção artesanal. Apoiando-se em Arnold Hauser (18921978), Motta associa o enfraquecimento do artesanato, na Europa, às "novas exigências de organização social", e avalia que o aniquilamento das tradições do artesanato provocou "um verdadeiro trauma na cultura ocidental"79.

William Morris e o movimento arts and crafts inserem-se justamente neste momento de transição. A sua importância, para a análise de Motta, vem justamente daí: expressam, com bastante clareza, as contradições presentes naquele século repleto de incertezas. Por um lado, trazem à tona a questão central da restauração da unidade das artes. A arquitetura, abraçando todo o "ambiente da vida humana", assume, então, o papel de "ação condensadora das demais manifestações plásticas" 80 .

Restaurar a unidade das artes significa, também, restaurar a relação entre arte e sociedade, recuperando a noção de uma arte "que vive numa sociedade que ela conhece" ${ }^{11}$. Assim, essa idéia aparece indissoluvelmente ligada à defesa da arte com um sentido social. A cisão entre o sensível (o subjetivo, individual, que inicialmente é expresso pelo ornamento) e o construtivo (o objetivo, diretamente determinado pelas exigências materiais) é associada ao distanciamento entre o artista e o povo.

É necessário considerar, nesta distância entre o artista e o povo, dois fatores fundamentais: um, como já dissemos, quando "os mestres do artesanato foram excluídos da vida econômica"; outro - agravado pelo primeiro - a necessidade de restabelecer a unidade entre o artista e o público.

Atendendo às exigências do primeiro, temos as tentativas de Morris e todo movimento em torno do artesanato no século XIX. O ornamento então era também reconhecido como uma conquista ao conteúdo novo. Além disso, as características produtivas da máquina dificultaram o aproveitamento desse impulso renovador. Coube, em grande parte, aos arquitetos essa transição entre o ornamento novo e as novas possibilidades construtivas. (...) Van de Velde conduz a construção para as inspirações primeiras do ornamento. ${ }^{82}$

Mas a contradição primordial de Morris e dos movimentos por ele influenciados está no fato de que defendem o saber fazer artesanal e a individualidade

79 MOTTA, Flávio. Contribuição ao estudo do art nouveau no Brasil. Tese (cátedra). São Paulo, FAUUSP, 1957, p. 8.

80 Id. "Art nouveau: um estilo entre a flor e a máquina". In: Cadernos Brasileiros, v. 28, n. 2, mar/ abr 1965, p. 58.

81 Id. Contribuição ao estudo do art nouveau no Brasil. Tese (cátedra). São Paulo, FAUUSP, 1957, p. 35. 82 lbid., p. 45-46. 
do artista-artesão para realizar a re-união entre fazer artístico e produção com finalidade social. Isto em um momento em que o domínio da máquina e a industrialização praticamente inviabilizam a manutenção dos antigos modos de produção:

\footnotetext{
As tendências de Morris, ensinando aos operários as técnicas mais evoluídas do artesanato (...) tudo, isso, em oposição à máquina, era realmente um navegar contra a correnteza, porque a Inglaterra não estava nas condições da Índia de Gandhi, onde a organização econômica e social baseada no artesanato foi uma das grandes forças da unidade nacional. ${ }^{83}$
}

As artes decorativas, meio caminho entre o artesanato e a indústria, surgem como uma solução apenas transitória.

Quando Morris tentou levar às últimas conseqüências, no plano prático, as suas concepções teóricas, surgiu o dramático impasse. Manteve (...) o prestígio das artes decorativas enquanto o artesanato permitia um tratamento semelhante entre a construção e o ornamento. O caráter pessoal, inventivo, peculiar do ornamento, não poderia competir com as exigências da máquina, não só nos seus aspectos técnicos, específicos, mas também no plano social e econômico. ${ }^{84}$

Os movimentos ligados às artes decorativas, entretanto, têm uma característica importante: ao valorizar o artesanato, a ligação entre o artista e o povo, a "satisfação das necessidades humanas", se contrapõem à defesa da "arte pela arte" - surgida como negação simples da máquina e da industrialização, e muito presente no século XIX. Apontam para um caráter social da arte e da arquitetura, e aí está uma chave para compreender a retomada do art nouveau e manifestações a ele relacionadas, por Motta, em plena década de 1950.

Os movimentos ligados às artes e ofícios têm seus ecos também no Brasil. No final do século XIX e primeiras décadas do século XX, artistas e arquitetos dão os primeiros passos na pesquisa de novas técnicas e materiais, buscando se aproximar da indústria nascente; dedicando-se às artes aplicadas, procuram a inserção em campos de atuação até então pouco explorados pelos artistas, como as artes gráficas e a produção de objetos e mobiliário. Os textos de Motta vão recuperar parte dessa história, mostrando como ela freqüentemente se refere ao art nouveau - movimento que, ao mesmo tempo em que valoriza o artesanato e as artes

83 MOTTA, F. Contribuição ao estudo do art nouveau no Brasil. Tese (cátedra). São Paulo, FAUUSP, 1957, p. 13.

84 lbid., p. 14. 
aplicadas, insere-se num contexto de admiração pelas recentes descobertas da ciência e avanços industriais.

Em Eliseu Visconti, por exemplo, Motta vai encontrar um artista múltiplo, que, no início do século XX, colabora com a indústria nascente na criação de produtos, organiza exposições de "artes decorativas aplicadas às indústrias artísticas" 85 , dá aulas e promove o ensino de arte, além de trabalhar como pintor e ilustrador, influenciado pelo "art nouveau, simbolismo e impressionismo" 86.

No campo da arquitetura, Motta lembra do crítico Araújo Viana, que, mesmo sem prescindir dos "elementos decorativos", é um dos primeiros a antever as novas relações tornadas possíveis pela técnica:

Com o ferro na construção, a arquitetura se modificou (...) A arquitetura se apóia hoje na ciência que progride, não recorrendo mais a estereometria da pedra, invoca resoluções de grandes problemas de arejamento higiênico e iluminação de vastíssimas naves. A ossatura metálica dessas naves permite armazenar, no palácio moderno, verdadeira atmosfera luminosa até a ilusão do ar livre em um recinto fechado. Se a arte dos edifícios é atualmente uma síntese onde se aplica ao serviço do ideal das artes do desenho as fórmulas positivas da ciência, convém que, com a violenta vizinhança do ferro e dos materiais pedregosos ou terrosos, se consiga a unidade na multiplicidade dos elementos decorativos. ${ }^{87}$

O arquiteto Carlos Ekman também é figura destacada, não apenas por seus projetos art nouveau como a Vila Penteado ou a escola de comércio Álvares Penteado. É um pioneiro na experimentação de novas técnicas, materiais e métodos construtivos:

Um livro sobre o Brasil, editado em 1913 na Inglaterra, por ordem do marechal Hermes da Fonseca, fala de Ekman como autor do primeiro edifício com estrutura de

85 MOTTA, F. Contribuição ao estudo do art nouveau no Brasil. Tese (cátedra). São Paulo, FAUUSP, 1957, p. 36.

86 O interesse de Motta por Visconti levará o autor escrever o artigo "Visconti e o início do século XX", de 1969. Este interesse pelo artista carioca é compartilhado com outros críticos de arte brasileiros, como Mário Pedrosa (1900-1981) - que escreve, em 1950, "Visconti diante das modernas gerações". Mas, enquanto Pedrosa se concentra na obra do pintor, enfatizando o seu anti-academismo, Motta destaca o seu caráter de artista múltiplo, que se adiantou aos homens de seu tempo, mas foi também expressão de sua própria época: "Se procurarmos demonstrar, no futuro, como o fenômeno poético de Visconti se oferece a uma determinada aspiração de nossa sociedade, diremos que ele se aproxima de uma forma de viver, fluente e sem asperezas, garantida por um momento econômico, na medida do possível, brasileiro. Visconti foi um 'codificador das sensações', como elas seriam mais tarde procuradas pela classe média beneficiária da Revolução de 1930 e do novo surto desenvolvimentista" (MOTTA, F. "Visconti e o início do século XX". In: PONTUAL, R. Dicionário das artes plásticas no Brasil. Rio de Janeiro, Civilização Brasileira, 1969).

87 MOTTA, F. Op. cit., p. 33. 
ferro, em São Paulo, a antiga casa Bamberg (...). O estudo das obras de Ekman revela, mesmo, o trabalho de um construtor consciencioso, tirando, como um bom sueco partido das estruturas de madeira, nos telhados ou nas escadarias. Ekman também importou da Suécia as primeiras casas pré-fabricadas, de madeira (...) É curioso que um arquiteto com preocupações estruturais, com experiências nos Estados Unidos e em seu país natal, tenha realizado um dos primeiros edifícios art nouveau em São Paulo.88

Mas a mais importante referência da presença e da influência do art nouveau no Brasil, para Motta, parece mesmo ser o Liceu de Artes e Ofícios de São Paulo, expressão de "uma certa consciência de uma necessária ligação entre a arte e o progresso técnico" 89 . O autor retoma a história (em parte esquecida) dessa escola, os nomes de seus professores e técnicos, a partir dos depoimentos do ex-diretor da instituição, Luiz Scatollini - que afirmava que por muito tempo "quase que não se fez outra coisa neste Liceu que o floreal", e que, em relação ao público, "o art nouveau foi aceito com entusiasmo (...) o povo, um pouco chocado no começo, aderiu logo (...) tudo o que era feito em matéria de móveis e objetos era logo adquirido" 90 .

Para Motta, o exemplo do Liceu é uma demonstração de que, nessa São Paulo do final do século XIX, as pesquisas e inquietações dos artistas ligados ao art nouveau e às artes aplicadas muitas vezes se casaram com as intenções "progressistas" de certas parcelas da burguesia, que procuravam unir "educação popular" e formação de mão-de-obra para suas recém-criadas indústrias.

\footnotetext{
Ampararam o Liceu figuras como (...) Bernardino de Campos, Siqueira Campos, Cerqueira César, Domingos Jaguaribe, Jorge Tibiriçá (...) Para avaliarmos a participação dessa elite no nosso movimento artístico, basta este trecho do discurso de Martim Francisco, em 1874: 'Salvemos, senhores, a liberdade e a ordem pela ação da justiça social; reconheçamos que a natureza não criou categorias entre os homens, que todos têm iguais direitos, e que, exigir em regra o privilégio, é destruir a lei da igualdade, condição essencial do desenvolvimento moral das sociedades modernas'. E acrescentava: 'Aí ao par de uma instituição que dia por dia amplia suas conquistas, a indústria prospera, a sorte do operário melhora e a riqueza pública aumenta'91.

Quando em 1882, a Sociedade [Propagadora da Instrução Popular] se converteu em Liceu, a finalidade foi 'ministrar gratuitamente ao povo os conhecimentos necessários às artes e ofícios, ao comércio, à lavoura e às indústrias'. Veja-se, portanto, que foram os liberais que garantiam o desenvolvimento, em São Paulo, de um centro artístico, onde não se descuidava das relações com os aspectos econômicos e sociais da época. ${ }^{92}$
}

88 MOTTA, F. "São Paulo e o art nouveau". In: Revista Habitat, n.10, 1953, p. 8.

89 ld. Contribuição ao estudo do art nouveau no Brasil. Tese (cátedra). São Paulo, FAUUSP, 1957, p. 28.

90 ld. "São Paulo e o art nouveau". In: Revista Habitat, n.10, 1953, p. 6.

91 O discurso de Martim Francisco foi encontrado por Motta na publicação O Liceu de Artes e Ofícios de São Paulo: histórico, estatutos, regulamentos, programas, diploma, editado pelo próprio Liceu em 1934 (Id. Contribuição ao estudo do art nouveau no Brasil. Tese (cátedra). São Paulo, FAUUSP, 1957, p. 49). 92 Id. Contribuição ao estudo do art nouveau no Brasil. Tese (cátedra). São Paulo, FAUUSP, 1957, p. 48. 
Rui Barbosa, preocupado com o ensino (e mais especificamente o ensino de desenho, relacionado ao "progresso industrial" do país"3) e o conde Álvares Penteado, industrial e fazendeiro que fez de seus recursos "instrumento de progresso" 94 , são exemplos do que o autor entende como "espírito renovador de alguns homens de elite do nosso princípio de século".

Mas o Liceu tem uma outra faceta: segundo Scatollini, "qualquer artífice ou mestre de valor que chegava do estrangeiro, era conquistado para o Liceu". Motta se refere detalhadamente aos artífices e mestres que trabalharam na escola e que se aproximaram do art nouveau, listando seus nomes e especialidades - talvez como indicação para futuras pesquisas, no campo da história da arte brasileira. Inclui os arquitetos nessa listagem, numa tentativa de demonstrar como, naquele momento, aproximavam-se os campos das artes aplicadas e da arquitetura:

a) serralheiros - Antonio Chiocca, Adolfo Giovanetti, Frederico Puccinelli, Giacomo Cabrobbi, Piazzo Fiorenzo; b) ornatos - Adolfo Borione e Agnielo Paciulli que trabaIhou na Vila Penteado; c) escultores que também trabalharam em ornatos: Amadeu Zani, Lorenzo Petrucci, William Zadig e um tal Giulio; d) arquitetos - Carlos Ekman, Ramos de Azevedo, Victor Dubugras (o mais revolucionário e avançado), Eduardo Loschi, o alemão Behmer, Hippolito Pujol, Giulio Micheli, Francesco Pucci, Heribaldo Siciliano, Maximiliano Hehl, Amaral e Simões (do Martinelli), Domiciano e Cláudio Rossi (do escritório Ramos de Azevedo, construíram o Teatro Municipal e raramente faziam art nouveau) e Giovanni Bianchi que dizem ter estudado em Milão com o arquiteto Somaruga, famoso pelos edifícios floreais. ${ }^{95}$

Assim, ao mesmo tempo em que valoriza as primeiras tentativas nacionais de expressão dos ideais de unidade das artes e aperfeiçoamento do desenho e do design, Motta ressalta a participação imigrante no desenvolvimento artístico paulista e brasileiro. Parte desses imigrantes, artesãos "de valor" (como diz Scatollini), trazem um conhecimento técnico-profissional especializado até então

93 Em Contribuição..., Motta refere-se ao "Parecer sobre o ensino primário", de Rui Barbosa, e a um discurso seu no Liceu de Artes e Ofícios do Rio de Janeiro, em 1882, onde o escritor e político faz um paralelo entre a história daquela escola e a "história da evolução intelectual" que "fez baixar a cultura artística da região desse Olimpo, inacessível ao vulgo" (MOTTA, F. Contribuição ao estudo do art nouveau no Brasil. Tese (cátedra). São Paulo, FAUUSP, 1957, p. 28).

94 Motta refere-se longamente a Álvares Penteado, "figura típica de fazendeiro e industrial, ilustrado no trato e na intimidade com a vida européia. Vivia os momentos faustosos daqueles primeiros dias da República. Possuía, entre outras coisas, várias indústrias e fazendas, com mais de 950.000 pés de café (...) A instalação de indústrias, escolas, casas de espetáculo, a iniciativa de trazer imigrantes italianos para as suas fazendas, tudo isso, fazia do Conde uma expressão clara da atividade progressista. Tendo herdado uma grande fortuna (...) viu, nos seus recursos, um instrumento de progresso material e cultural, não se restringido à simples manutenção de herança vultosa. Quando ele chamou o arquiteto Ekman para construir sua residência em art nouveau, estava tomando uma posição avançada para o nosso meio" (MOTTA, F. "São Paulo e o art nouveau". In: Revista Habitat, n.10, 1953, p. 8).

95 Ibid., p. 6-8. 
pouco presente no país; e milhares de outros, anônimos, colaboram com o processo de industrialização, como operários do nascente parque industrial paulista ${ }^{96}$. É possível perceber que por trás dessa recuperação histórica (em si importante, já que é uma parte da história que vinha sendo ignorada pelos críticos e historiadores da arte), há o início de um trabalho de recuperação de uma moral do trabalho, de um principio criativo que tem como um de seus elementos-chave o saber-fazer cotidiano da classe trabalhadora - que, nesse momento da obra de Motta, é representada pelos imigrantes europeus, mas que posteriormente se estenderá aos próprios brasileiros, à cultura popular do nordeste ou das periferias das grandes cidades ${ }^{97}$.

\section{Limites do art nouveau}

Todas essas movimentações do Brasil de fin de siècle irão, entretanto, encontrar sérias limitações ao seu pleno desenvolvimento. As limitações do art nouveau brasileiro são tantas que, numa primeira leitura dos textos, tem-se a impressão de que, afinal, o movimento não teria de fato muita importância para a história da arte brasileira e tampouco como precursor do movimento moderno. O próprio autor admite que, na verdade, o art nouveau seria "um dos tantos traços de nossa civilização transplantada, com raros exemplos de revisão crítica"98.

[No Brasil], o art nouveau ficou onde poderia ficar, isto é, em algumas manifestações de arte decorativa, nas revistas, no teatro. Definiu um momento de entusiasmo em certos grupos, teve o gosto efêmero dos modismos e apareceu, retardatário, infil-

96 Segundo Arruda, no período áureo da imigração, entre 1882 e 1930, mais de dois milhões de pessoas chegaram a São Paulo (um número que correspondia a 18\% da população total do estado); os italianos eram a grande maioria, cerca de $50 \%$ do total. Na década de 1940, as migrações internas tomam o lugar das imigrações, e entre 1941 e 1949 a cidade recebe mais de 400 mil brasileiros procedentes principalmente dos estados do Nordeste e de Minas Gerais. Assim, na década de 1950, "São Paulo se apresenta com um perfil cosmopolita e moderno", com um "denso repertório de linguagens culturais"; a autora destaca que é justamente nessa década que os descendentes dos imigrantes chegados até a década de 1930 alcançam o "topo da escala social (...) com presença constante nos meios de comunicação social, nos aparelhos culturais, na literatura, no cinema, no teatro" (ARRUDA, M. A. Metrópole e cultura: São Paulo no meio do século XX. São Paulo, Edusc, 2001, p. 57-58).

$97 \mathrm{Na}$ obra de Motta, esse percurso de valorização da dimensão do trabalho é muito claro. Enquanto na década de 1950 o art nouveau e as manifestações das artes aplicadas do século XIX são seus principais objetos de estudo, nos anos 70 irá retomar os artistas proletários da Família Artística Paulista, e valorizar manifestações populares anônimas, como o célebre "fifó" - lamparina feita de uma lâmpada reaproveitada - no texto "Arte e vida urbana no Brasil", de 1970. Talvez seja possível dizer que essa valorização da dimensão do trabalho não se refere a uma defesa exclusivista do artesanato, mas sim, de forma mais ampla, a uma defesa do domínio da técnica pelo homem, em favor da expressão criativa - que também poderia ocorrer com o uso dos meios industriais, como discute Motta em "As esculturas de plástico de Mário Cravo Junior", também de 1970.

98 MOTTA, F. Contribuição ao estudo do art nouveau no Brasil. Tese (cátedra). São Paulo, FAUUSP, 1957, p. 07. 
trando-se no ensino do desenho nas escolas secundárias. A mesma dificuldade em uma revisão crítica permitiu a permanência do art nouveau; onde penetrou, muitas vezes ficou, acomodado à rotina. ${ }^{99}$

Motta insiste em chamar atenção para o fato que essa revisão - que está na base de sua proposição enquanto historiador da arte - raramente aconteceu na história da arte brasileira. Assim, não é tão paradoxal que os momentos mais esclarecedores e instigantes de sua leitura sejam justamente aqueles em que vai além do próprio art nouveau, dando concretude ao trabalho de problematização histórica ao identificar as contradições do objeto estudado.

Segundo o autor, a importância do art nouveau, no Brasil, dever-se-ia ao fato de que, no princípio do século $X X$, em um ambiente fortemente influenciado pelas tradições acadêmicas, "qualquer renovação, mesmo dentro do ornamento, seria positiva; qualquer consideração em torno do art nouveau como reação ao revival; qualquer estímulo à criação de caráter mais pessoal e renovador, era um impulso que contrariava a rotina"100. O floreal traria também o ideal das artes industriais, o respeito e o estímulo ao artesanato; teria tido um caráter cosmopolita, algo importante para uma ex-colônia, de ambiente cultural rarefeito; e teria influenciado o ensino artístico de desenho, graças aos esforços de individualidades como Visconti.

Assim, apesar de reconhecer que o art nouveau teria participado "da realidade cultural do país", firmando alguns "métodos, normas e princípios que ainda hoje sobrevivem"101, Motta conclui afirmando que, aqui, o art nouveau "não compreendeu com exatidão as verdadeiras possibilidades da máquina como instrumento da cultura" 102; "descambou, com facilidade, para o caricato; substituiu a galanteria pela coquetterie; o minueto pelo cancã, a ironia pela piada. E nos deu assim (...) o instantâneo do fin de siècle" 103 .

Eram muitas as limitações ao desenvolvimento de um movimento artístico consistente: a industrialização em 1900 era ainda incipiente, a vida intelectual, provinciana, a arquitetura e as artes estavam presas aos cânones acadêmicos. Motta

99 MOTTA, F. Contribuição ao estudo do art nouveau no Brasil. Tese (cátedra). São Paulo, FAUUSP, 1957,

p. 46.

$100 \mathrm{lbid}$., p. 36.

101 lbid., p. 7.

102 Id. "São Paulo e o art nouveau". In: Revista Habitat, n.10, 1953, p. 7.

103 Id. "Art nouveau: um estilo entre a flor e a máquina". In: Cadernos Brasileiros, v. 28, n. 2, mar/ abr 1965, p. 55. 
associa essas limitações à existência histórica de uma dependência brasileira, enquanto país colonial. Nas artes, assim como na política, conquistamos, no Brasil, uma "independência por imitação, já que nos faltava uma estrutura sedimentada para impor formas evoluídas de expressão"104. Reforçando este paralelo, Motta afirma:

[No Brasil] o art nouveau passa a representar o liberalismo que orientava a vida política (...) contra os dogmas e estilos preestabelecidos (...) Assim como o liberalismo descuidara de organizar os elementos básicos da estrutura social, também o art nouveau tornou-se, em grande parte, um estilo de formas decorativas a enfeitar superfícies. ${ }^{105}$

Na própria análise dos exemplos concretos do art nouveau brasileiro, eleitos pelo autor como significativos, as limitações voltam a aparecer claramente. O Liceu de Artes e Ofícios de São Paulo, por exemplo, preso às exigências da clientela e às necessidades de manter a sua própria subsistência, "não conseguiu um entrosamento maior com a indústria". Segundo Motta, "apartado dessa realidade, os seus produtos adquiriram mais tarde alto preço, dada a inegável qualidade da mão de obra, mas sem significação como produto de uma mentalidade moderna". Nesta escola, o floreal cria um ambiente de entusiasmo para, finalmente, ser ridicularizado como "estilo macarrônico"106. Colocado numa perspectiva histórica,

(...) todo trabalho do Liceu se reduziu a um pequeno campo de aperfeiçoamento e educação profissional, para mais tarde assistir, inerte, a um segundo e maior domínio do progresso industrial, amparado em organizações semi-oficiais e um ensino profissional de caráter mecanicista. ${ }^{107}$

Revela-se também, que, dentre os trabalhos de Ekman, "o mais art nouveau foi a Vila [Penteado]. Nos demais, usou apenas um ou outro ornamento (...) o art nouveau foi instante passageiro na sua carreira de arquiteto" ${ }^{108}$. Este edifício, considerado hoje um dos últimos remanescentes do floreal paulistano, é apenas, segundo Motta, "discretamente art nouveau", no que se refere a seus aspectos construtivos.

104 MOTTA, F. Contribuição ao estudo do art nouveau no Brasil. Tese (cátedra). São Paulo, FAUUSP, 1957,

p. 28.

105 MOTTA, F. "São Paulo e o art nouveau". In: Revista Habitat, n.10, 1953, p. 7.

106 Id. Contribuição ao estudo do art nouveau no Brasil. Tese (cátedra). São Paulo, FAUUSP, 1957, p.

48.

107 Ibid., p. 49.

108 lbid., p. 48. 

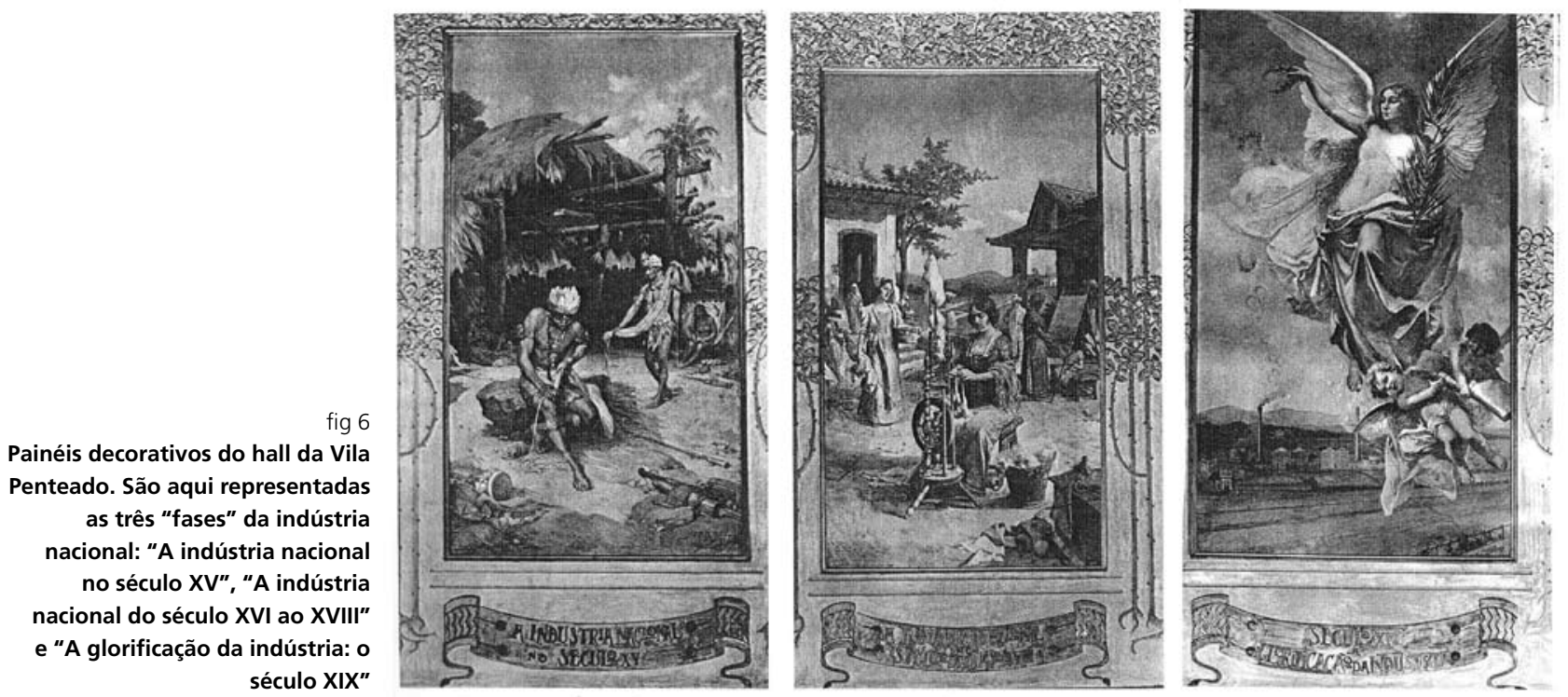

Ainda discutindo a Vila Penteado, Motta aponta, em certos historiadores do Brasil, uma tendência "em fazer do café e da borracha os alicerces do progresso industrial; um velho ideal fisiocrata herdado do Império pelos primeiros republicanos. As alegorias pintadas no hall da Vila (...) ilustram essa curiosa idéia do progresso técnico, remontando aos nossos aborígines. Ali está, no seu otimismo romântico, uma visão de continuidade da industrialização no Brasil, até a ascensão final, glorificadora e apoteótica da indústria paulista do século XX"109. Motta contrapõe-se a esta narrativa, colocando que ela seria "bem o contrário da realidade":

(...) o que tínhamos era o impacto do novo, com a vinda do imigrante, com a instalação de vias férreas, empresas hidrelétricas, enfim toda uma série de forças elaboradas num meio estranho ao nosso. (...) Se na Inglaterra, o ideal de restauração do artesanato levara a um conflito com a crescente industrialização, que se dirá, do Brasil, onde, além de um choque nos métodos de produção, tínhamos choques de culturas, de mentalidades, na complexa mescla de tendências as mais contraditórias! 110

E conclui:

Estando o art nouveau de Ekman reduzido praticamente a um exemplo; restando ao Liceu (...) a missão, em parte frustrada, em torno das artes aplicadas, poderia parecer que pouco ficou do art nouveau que servisse à transição para o Movimento Moderno. Necessário seria, para assim concluirmos, deixar à margem a atividade do arquiteto Victor Dubugras. ${ }^{111}$

109 MOTTA, F. Contribuição ao estudo do art nouveau no Brasil. Tese (cátedra). São Paulo, FAUUSP, 1957, p. 48.

110 lbid., p. 49

$111 \mathrm{lbid}$. 
Assim, Dubugras (e o neocolonial ${ }^{112}$, movimento ao qual este arquiteto liga-se depois de uma fase de obras no estilo floreal) surgem um tanto repentinamente nos textos sobre o art nouveau, o que, à primeira vista parece ser mais um sinal das limitações do movimento, até mesmo enquanto objeto de crítica. Mas, num olhar mais aprofundado, a transição art nouveau neocolonial revela-se como uma forma de olhar para estes dois movimentos em relação, e repensar o significado deles para a história da arte e da arquitetura brasileira. Retomando a trajetória do arquiteto francês, que adere ao neocolonial por volta de 1914, Motta afirma:

Vemos (...) através da obra de Dubugras, que a sua arquitetura sofreu uma evolução paralela àquela verificada na Europa. Partiu do Neogótico e atingiu inclusive a soluções de grandes edifícios envidraçados (...) Porém, faltavam-Ihe aquelas características da tradição nacional que enriqueceram o art nouveau na Europa. Ele reconsidera então o problema e cria depois do art nouveau, que foi uma destruição dos neos, o neocolonial brasileiro, reincorporando o problema do ornamento. ${ }^{113}$

A relação entre art nouveau e neocolonial permite que os dois movimentos sejam lidos como momentos complementares - e não opostos - na história da arte brasileira ${ }^{144}$. O art nouveau, além de se constituir como uma primeira reação antiacadêmica, coloca o problema premente da industrialização brasileira; permite uma explicitação da discussão sobre o caráter, as possibilidades e impossibilidades dessa industrialização, em relação com o desenvolvimento artístico e cultural.

112 O movimento Neocolonial tenta propor novas bases para a modernização da arquitetura no Brasil. Ricardo Severo (1896-1940), arquiteto português e um de seus principais expoentes, defende o estudo da arte colonial para a "perfeita cristalização da nacionalidade", com a retomada do barroco e do rococó, e a defesa de um retorno às obras de Mestre Valentim e de Aleijadinho e às construções do século XVIII português. Para o Neocolonial o culto à tradição e a exaltação das raízes culturais e étnicas portuguesas estariam na base da defesa de uma arte brasileira e de um "renascimento arquitetônico" - numa contraposição ao ecletismo arquitetônico reinante nos séculos XIX e XX. O movimento propõe uma reação nacionalista que se quer, ao mesmo tempo, tradicional e moderna. É impulsionado por publicações como o jornal O Estado de S.Paulo e a Revista do Brasil e encontra ampla acolhida num contexto intelectual fortemente marcado pelo nacionalismo, reverberando em eventos importantes como a Exposição do Centenário no Rio de Janeiro e a Semana de Arte Moderna, em São Paulo, ambos em 1922. Escritores como Monteiro Lobato, Ribeiro Couto, Manuel Bandeira e Mário de Andrade, o médico e historiador da arte José Mariano Filho, além artistas e arquitetos como Wasth Rodrigues, Alexandre Albuquerque, Adolfo Pinto Filho, Araújo Viana, Heitor de Melo, Archimedes Memória, Rafael Galvão, Victor Dubugras, Lúcio Costa, entre outros, aderem ao movimento (Fonte: Enciclopédia Itaú Cultural de Artes Visuais, <www. itaucultural.org.br>. Acesso em 21/06/2010).

113 MOTTA, F. Contribuição ao estudo do art nouveau no Brasil. Tese (cátedra). São Paulo, FAUUSP, 1957, p. 53. Grifo nosso.

114 É possível relacionar essa aproximação entre art nouveau e neocolonial com a reflexão que Antonio Candido faz em 1959, sobre a proximidade - histórica, e não estética - entre o arcadismo e romantismo literários. Segundo Schwarz, embora estes estilos fossem diferentes e até opostos, eles formam um único "objeto", se analisados do ponto de vista do "signo unificador da independência nacional em processo" (SCHWARZ, R. "Os sete fôlegos de um livro". In: Seqüências brasileiras: ensaios. São Paulo, Cia das Letras, 1999, p. 49. 
No Brasil, entretanto, as "características de tradição nacional" estão ausentes do art nouveau - e é o neocolonial que irá fazer essa discussão acerca da existência de "tradições nacionais" brasileiras e das formas possíveis de sua apreensão, nas primeiras décadas do século $X X^{115}$. Revisar histórica e criticamente este movimento, em plena década de 1950, é mais uma demonstração de como naquele momento a preocupação de repensar as relações entre a história e uma produção contemporânea e ao mesmo tempo nacional, reaparecia no centro dos debates $^{116}$. A leitura de Motta, colocando Dubugras como uma ponte entre o art nouveau e o neocolonial, e ao mesmo tempo um precursor do moderno, inaugura uma nova vertente historiográfica ${ }^{117}$.

115 Lembremos que em 1928 Mário de Andrade, discutindo as relações entre a nascente "arquitetura modernista" e o neocolonial, coloca-o como uma possibilidade de "procura e fixação dos elementos da constância arquitetônica brasileira", ou seja, um movimento com potencial de alimentar a universalidade modernista com elementos étnicos e nacionais. No mesmo artigo, também deixa registrada a dúvida acerca do uso da tradição efetuado pelo neocolonial: "Ora os arquitetos que estão trabalhando por normalizar no país um estilo nacional 'neocolonial' (...) estão funcionando em relação à atualidade nacional. A função deles é pois, perfeitamente justificável e mesmo justa. O que resta saber é se estão funcionando bem" (ANDRADE, M. "Arquitetura colonial", 1928. In: Arte em Revista no. 4, ago 1980, p. 14).

116 Poderíamos exemplificar este ressurgimento da afirmação de uma arquitetura com características nacionais por Vilanova Artigas, que, preocupado com a questão, escreve artigos como "Considerações sobre arquitetura brasileira", em 1954, e "Arquitetura e cultura nacionais", em 1959 - alguns autores, como Thomaz, chegam mesmo a identificar uma mudança de terminologia em seus textos a partir de meados da década de 1950, quando o arquiteto passa a usar o termo "arquitetura brasileira" ao invés de "arquitetura moderna brasileira" (THOMAZ, D. Artigas: a liberdade na inversão do olhar. São Paulo, FAUUSP (Tese de doutorado), 2005, p. 248-249). No mesmo sentido, podemos lembrar do IV Congresso de Arquitetos, em 1954, que tinha como uma de suas temáticas "Arquitetura e tradição" e pretendia fazer uma grande exposição mostrando a evolução da arquitetura brasileira ao longo dos séculos (cf. nota 1, Capítulo 2).

117 Inversamente à perspectiva de revisão histórica de Motta, Lucio Costa, na década de 1950, continua a negar a validade arquitetônica do neocolonial, movimento do qual ele próprio foi um dos principais expoentes. Em "Muita construção...", o arquiteto lista o neocolonial como mais uma manifestação sem sentido "orgânico funcional: "o neocolonial, fruto da interpretação errônea das sábias lições de Araújo Viana (...) teve como precursor Ricardo Severo e por patrono José Mariano Filho. Tratava-se, no fundo, de um retardado ruskinismo, quando já não se justificava mais, na época, o desconhecimento do sentido profundo implícito na industrialização, nem o menosprezo por suas conseqüências inelutáveis. Relembrada agora, ainda mais avulta a irrelevância da querela entre o falso colonial e o ecletismo dos falsos estilos europeus (...) Equívoco ainda gravado pelo desconhecimento das verdadeiras características da arquitetura tradicional e conseqüente incapacidade de lhe saber aproveitar convenientemente aquelas soluções e peculiaridades de algum modo adaptáveis aos programas atuais, do que resultou uma verdadeira salada de formas contraditórias provenientes de períodos, técnicas, regiões e propósitos diferentes" (COSTA, L. "Muita construção, alguma arquitetura e um milagre, 1951. In: XAVIER, Alberto [org]. Lucio Costa: sobre arquitetura. Porto Alegre, UniRitter, 2007, p. 185-186). Curiosamente, nesse texto, no qual se refere nominalmente a inúmeros arquitetos e engenheiros que participaram da produção arquitetônica do Rio de Janeiro no fin de siècle, Costa ignora Victor Dubugras - que, segundo Motta, construiu também no Rio de Janeiro. 


\title{
Limites do moderno
}

A retomada dos dois movimentos do início do século $X X$, art nouveau e neocolonial, mostra-se como um trabalho importante do ponto de vista da "revisão histórico-crítica", com a discussão das limitações a serem superadas no desenvolvimento artístico brasileiro. Mas, apontando já para a conclusão de seu estudo, Motta indica que seria somente o movimento moderno que colocaria possibilidades efetivas de síntese entre tradição nacional e técnica moderna, de união entre as artes, e de re-união entre arte e sociedade, o artista e o povo. No Brasil,

\begin{abstract}
caberia a Lúcio Costa, que se iniciou com o Neocolonial (Embaixada da Argentina) ${ }^{118}$, Oscar Niemeyer e outros, retomar o problema em termos construtivos mais compatíveis com o movimento de industrialização que se processava depois da Revolução de 1930. É bem verdade que essa industrialização ainda era, fundamentalmente, amparada pela produção cafeeira. A vinda de Le Corbusier, o trabalho de Warchavchik, facilitaram uma revisão das nossas tradições barrocas, mesclando soluções racionalistas com o promenade architecturale de Le Corbusier ou a assim chamada "forma livre" de Oscar Niemeyer, onde o espírito inventivo, a fantasia se manifesta em formas orgânicas combinadas com os rigores da linha reta. ${ }^{119}$
\end{abstract}

O advento da arquitetura moderna na década de 1930, e seu posterior reconhecimento internacional, entretanto, não impedem o autor de apontar a persistência de "deficiências" no desenvolvimento artístico brasileiro. Apesar dos avanços da técnica e do relativo desenvolvimento industrial - um desenvolvimento que, num primeiro momento, se baseia no setor agro-exportador ${ }^{120}-$, a "inconseqüência de nossa evolução", sempre a ameaçar qualquer tentativa de estabelecimento de continuidade, não poderia ser esquecida:

\footnotetext{
Não devemos esquecer que esse movimento moderno pede uma resposta do progresso industrial, do aprimoramento dos métodos de ensino, da qualidade das iniciativas divulgadoras, como exposições, museus, etc. Não devemos esquecer as deficiências de uma experiência artesanal, superando o nosso já decantado preconceito pelo trabalho manual. Não devemos esquecer que nosso ensino ainda está viciado por um mau aproveitamento do art nouveau e pela formação acadêmica.
}

Não devemos, finalmente, descuidar das características do art nouveau como um movimento que foi de certo modo detido pela inconseqüência de nossa evolução. É necessário, para a arquitetura moderna brasileira resistir e formar tradição, que se

118 Motta faz questão de enfatizar, aqui, o fato de Lucio Costa ter iniciado a sua carreira no neocolonial, o que nos parece bastante importante, já que o próprio arquiteto depois passa a negar a relevância desse movimento.

119 MOTTA, F. Contribuição ao estudo do art nouveau no Brasil. Tese (cátedra). São Paulo, FAUUSP, 1957, p. 54.

120 A base "agrária" da industria nacional certamente é vista por Motta como um dado problemático, já que, nas décadas de 1950 e 1960, o autor a todo momento defende um desenvolvimento nacional "autônomo" e a "emancipação nacional". 
alimente dos benefícios técnicos, dos dados da técnica moderna que a industrialização oferece. $^{121}$

Estes parágrafos finais de Contribuição... fazem o alerta que a nosso ver é um dos pontos centrais da posição de Motta: seguindo o método da problematização histórica, revela que as limitações e deficiências do art nouveau, afinal de contas, poderiam ser as mesmas a serem enfrentadas pelo movimento moderno. A busca pela tradição, assim, não se restringiria às manifestações do passado; no tempo presente, para a sobrevivência da arquitetura moderna e de sua funcionalidade, essa tradição precisaria ser criada e, além disso, alimentada pela técnica moderna e pela industrialização.

\subsection{Motta, Habitat e os fundamentos da reconstrução histórica}

Seria improdutivo aprofundar a leitura da obra de Motta sobre o art nouveau sem relacioná-la às posições de Habitat. A revista de certa forma atualiza, trazendo para década de 1950, vários dos problemas e questões colocados ou apenas intuídos por Mário de Andrade nas décadas anteriores. Poderíamos buscar, em suas páginas, inúmeros artigos em que estas questões ficam claras; preferimos, entretanto, nos referir ao editorial do primeiro número da revista, transcrito aqui integralmente:

\footnotetext{
A história das artes no Brasil continua ainda em grande parte inédita: por enquanto não passa de uma crônica contemporânea que progride com surpreendente celeridade. Assim é que o passado tão rico em temas para re-evocação e a efervescente atividade do presente não encontram ainda uma documentação e uma informação adequadas à realidade e à sua importância, embora dia a dia aumente o desejo de se conhecer o que se faz no país e fora dele em matéria de arte. Basta para tanto refletir sobre o extraordinário incremento da arquitetura hodierna, o impulso dado à cultura pelos novos museus, as afirmações da pintura, o surto das artes industriais, para não falar da difusão da música e da sua divulgação para além das fronteiras, e do entusiasmo com que está sendo encarado o problema do teatro e do cinema, para se avaliar em que termos o Brasil colocou o problema e pretende resolver a questão das artes como fato educativo. Estes cadernos, que deverão sair de três em três meses em caráter experimental, pretendem traçar um roteiro do conjunto destas atividades. Partindo do fator paisagem cuja fisionomia vai sendo modificada pelos novos planos agrícolas e urbanísticos, o nosso interesse será voltado para o trabalho daqueles que com candura se exprimem através das artes populares. Também a arquitetura, já de fama mundial, será apresentada em suas mais características inovações e soluções mais afins com a civilização tropical. "Habitat" significa ambiente, dignidade, conveniência, moralidade de vida, e portanto espiritualidade e cultura: é por isso que escolhemos para título desta nossa revista uma palavra intimamente ligada à arquitetura à qual damos um valor e uma interpretação não apenas artísti-
}

121 MOTTA, F. Contribuição ao estudo do art nouveau no Brasil. Tese (cátedra). São Paulo, FAUUSP, 1957, p. 54. Grifo nosso. 
ca, mas uma função artisticamente social. A pintura, a escultura, as artes decorativas em seus vários setores ligadas à madeira, à cerâmica, ao vidro, aos metais, às artes de reprodução e impressão, e a todas as demais atividades costumeiras da vida de cada dia representam para nós motivos a serem apontados particularmente quando estas manifestações mais de perto exprimam a genialidade do país. O mesmo se diga para a música, o teatro e o cinema desde que não entrem em jogo, sobretudo nesta última espécie, as habituais negociatas; nossa revista procurará compor também neste setor um panorama unitário e lúcido. Isto no que se refere ao presente. Do passado pretendemos haurir germes da vida, não por mera exumação histórica, mas sim porque nós nos consideramos resultantes de tempos idos; dedicaremos pois ensaios à história da arte brasileira a fim de fundir os tempos numa só época, sem a baliza das classificações, dividindo o antigo do assim chamado moderno - adjetivo que entrou infelizmente em voga. A beleza imaginativa de floresta, de uma cabana de pau-apique, de um pote marajoara, de uma igreja barroca, o Aleijadinho, os ourives da Bahia, os movelheiros manuelinos de Recife, os epígonos da missão francesa, os arquitetos do Teatro de Manaus e os do Ministério da Educação e Saúde no Rio, os pintores caipiras e artistas de renome, ceramistas, os gameleiros do litoral, indígenas, africanos, descendentes de conquistadores, emigrantes, todos os que contribuíram e continuam contribuindo e participam de alguma forma da arte no Brasil, terão as suas atividades registradas em Habitat com o empenho de quem sabe apreciar o que de mais característico tem o país. ${ }^{122}$

De autoria de Lina bo Bardi, a argumentação do editorial é extremamente clara e sintética, permitindo esclarecer e aprofundar a compreensão sobre o que fundamenta a visão de Motta sobre o art nouveau, assim como as motivações de sua revalorização do século XIX.

\section{História}

Como Motta, Habitat parte de uma preocupação em relação à necessidade do "historiador sistemático e com visão geral do desenvolvimento cultural"123, que aparece logo na primeira linha do editorial, quando fica explícito que a revista considera como uma de suas funções inaugurar a história das artes no Brasil. Essa preocupação - motivada pelo extraordinário incremento da arquitetura, o surto nas artes etc, assim como pelo fato da "questão das artes" ser entendida como "um fato educativo" - determina a leitura da história proposta pela revista.

Contrariando a lógica da formação, na chave de Costa, e seu entendimento das manifestações do período colonial como as mais autênticas expressões da nacionalidade, Habitat defende a não-separação entre arte moderna e antiga - o que inclusive implica que, no caso da arte brasileira, as manifestações do Império e principalmente da República Velha deixem de ser desvalorizadas. A idéia da "fusão dos tempos numa só época, sem a baliza das classificações", aliada à valorização do artesanato e das artes aplicadas, confere a essas manifestações um status

122 BARDI, L. "Prefácio". In: Revista Habitat, no. 1, 1950, p. 1.

123 MACHADO, L. G. Retrato da arte moderna do Brasil. São Paulo, Depto. de Cultura, 1947, p. 11. 
equivalente ao de outras épocas históricas ${ }^{124}$. Propõe-se, assim, uma nova leitura da história enquanto continuidade. Como escreve Lina, em 1957:

\author{
As heranças são pesadas, e as "não-heranças" são perigosas e dificilmente superáveis \\ por falta de exemplos que, apesar de tudo, criam a "atmosfera" da cultura. (...) o \\ que reputamos necessário, hoje em dia, é um justo meio (...) uma espécie de medida, \\ naturalmente crítica, que, levando em consideração a história como herança e con- \\ tinuidade, abra as mais amplas liberdades às possibilidades do arquiteto, hoje mais \\ do que nunca responsável pelo "modo de viver" dos homens. ${ }^{125}$
}

\title{
A recusa do "vezo modernístico" 126 implica em uma continuidade inclusiva e pro- blematizada, como a de Mário de Andrade ${ }^{127}$. Problematizada porque, defen-
}

124 Podemos nos referir a diversos artigos de Habitat que expressam tal posição, trazendo uma temática e, em alguns casos - como nos artigos de autoria de Motta - uma abordagem até então inéditas, na historiografia da arte e arquitetura brasileiras. "Arquitetos em São Paulo em 1880", por exemplo, faz um percurso pela cidade do fim do século XIX, seus bairros e construções. Lamenta "que uma publicação como o Brazil Builds, considerada excelente sobre nossa evolução arquitetônica, não mencione nem de longe o caso paulista, único em todo o Brasil". E alerta o leitor de que os bairros paulistas do século XIX estão "ameaçados pela picareta dos demolidores, não tardando muito para que as construções do período medeando entre 1880 e o advento do Modern Style, se tornem tão raras em São Paulo como Rio de Janeiro as do tempo de Debret e D. João VI". (PRADO, J. F. de A. "Arquitetos em São Paulo em 1880". In: Revista Habitat, no. 3, 1951, p. 50). O artigo não assinado "Para um Museu de Café" propõe a criação de um museu reunindo "tudo quanto pertence à história dessa planta e o significado da mesma no tempo e na história, sobretudo dum ponto de vista visivo [visual]". Embora a proposta não se restrinja geograficamente a São Paulo ou cronologicamente aos séculos XIX e principio do XX, a "opção cultural" pelo café é significativa, no contexto em que o artigo é escrito ("Para um museu de café". In: Habitat 7, 1952, p. 71). "Álbum de fotografias", por sua vez, reproduz diversas fotografias de um "velho álbum de família" do fim do século XIX, acompanhadas da seguinte explicação: "Publicamos essas fotografias por varias razões: primeiro, para documentação da história do costume do fim do século, nas cidades brasileiras. Segundo, por ser documentação da arte do retrato fotográfico. Outras razões ainda: homenagem às pessoas, talvez desconhecidas que, nos primeiros anos da República, contribuíram, embora modestamente, à construção desse nosso grande País" ("Álbum de fotografias". In: Habitat 11, 1953, p. 44-47).

125 BARDI, L. Contribuição propedêutica ao ensino da Teoria da Arquitetura, 1957. São Paulo, Instituto Lina bo e P.M. Bardi, 2002, p. 50-51 apud STUCHI, F. Revista Habitat: um olhar moderno sobre os anos 50 em São Paulo. São Paulo, FAUUSP (Tese de Mestrado), 2006, p. 92. Grifo nosso.

126 Vejamos o que Lina entende por "vezo modernístico": "É preciso (...) chegar-se a um acordo sobre a palavra 'Moderno'. Passada a época da revolta contra as correntes reacionárias da arte, cessada a necessidade do 'choque', do escândalo, chegando ao ponto em que a arte moderna é aceita por todos, é necessário começar-se a construir considerando encerrado o período da necessária 'destruição', sob a pena de se fazer parte das 'vanguardas retardatárias' e se ser colocado fora da realidade moderna". (BARDI, L. "Museu de Arte Moderna da Bahia", 1959. In: Lina bo Bardi. Instituto Lina bo e P.M. Bardi, 1996, p. 139). Podemos apontar aqui, mais de uma década depois de "O movimento modernista" de Mário de Andrade, uma continuidade de pensamento, no que se refere a defesa de um caráter construtivo para a arte moderna - o que implica, também, em uma retomada do passado e da tradição, sem prescindir dos "avanços" obtidos (ANDRADE, M. "O movimento modernista", 1942. In: Aspectos da literatura brasileira. Belo Horizonte, Itatiaia, 2002, p. 253-280).

127 A continuidade de Habitat, assim, difere da continuidade seletiva e pouco conflituosa proposta por Lucio Costa e adotada por grande parte dos críticos e historiadores do movimento moderno brasileiro que fundamenta a brasilidade do movimento moderno por meio de suas raízes barrocas e luso-brasileiras, considerando o século XIX como um hiato, uma lacuna inexplicável. 
dendo que a história seja considerada a partir de uma posição crítica - que se coloca num "justo meio" entre as tradições como amarras à criação e a negação total das tradições -, Habitat não se furtará a expor o desenvolvimento artístico brasileiro como fruto de diferenças (de classe ou situação social, geográficas, históricas, ambientais, etc.) e insuficiências. Até mesmo as tentativas fracassadas de formação de tradição são valorizadas, na medida em que são estudadas enquanto possibilidades: Motta, por exemplo, considera o seu trabalho uma pesquisa das "possibilidades que o art nouveau ofereceu aqui para formar tradição, como formou no caso Europeu"128 - e por isso não deixa de relatar e discutir as limitações do seu objeto de estudo.

\section{E cultura}

A escolha da palavra "habitat" (que também significa ambiente) como título da revista indica uma concepção de cultura bastante abrangente e inclusiva - não apenas na consideração de novos períodos históricos e localidades na história da arte brasileira, mas em relação à própria concepção do que é a arte e quem são os artistas.

Para Habitat, a "arte" equivale à "cultura", e nelas cabem a pintura, a escultura, as artes decorativas e as artes gráficas, o cinema, o teatro; incluem-se artistas eruditos e artistas populares (caipiras, indígenas, africanos, emigrantes), a arte industrial e o pré-artesanato, o design e a etnografia. Como não remeter à proposta de Mário de Andrade no "Anteprojeto para criação do Serviço de Patrimônio", de 1936?

Nesse conjunto, a arquitetura ocupa uma posição de destaque: o fato de Habitat incluir a arquitetura, especificamente, na categoria mais ampla da cultura significa reconhecer a sua capacidade de projetar o ambiente (em ligação com o urbanismo e a planificação) e sua qualidade de "unificadora das artes", capaz de realizar a desejada "integração cultural" - que, como já dissemos, é entendida como uma forma de reaproximar a arte e o povo. Como diz Motta,

\footnotetext{
a distância da arte com o povo era inevitável, como será, enquanto a união das artes, como reflexo de ampla integração cultural, não despertar nesse povo a consciência de sua capacidade construtiva, compreendida como um todo orgânico. ${ }^{129}$
}

128 MOTTA, F. Contribuição ao estudo do art nouveau no Brasil, 1957. Tese (Cátedra). São Paulo, FAUUSP, 1957, p. 7.

129 Ibid., p. 45-46. 
Essa concepção é claramente relacionada àquela de William Morris, que considera que a arquitetura, em colaboração com as outras artes, deve projetar todo "o ambiente da vida humana"130, e contraposta àquela de Lucio Costa, que na década de 1950 distingue a "arte plástica verdadeira" (que estaria na "essência" da arquitetura) das outras "manifestações culturais" 131.

Ao defender uma função "artisticamente social" para a arquitetura, a revista nega à arte qualquer autonomia ou isenção; é um entendimento dialético da relação entre o artista (ou o arquiteto) e a sociedade, próximo das posições defendidas por Mário de Andrade ${ }^{132}$. Na "atitude estética", a técnica (ou o aprendizado do material) coloca-se, em relação à arte, como fator necessário de ligação do indivíduo com a coletividade.

130 Em 1965, Motta irá reproduzir a seguinte citação de Morris, no texto "Art nouveau: um estilo entre a flor e a máquina": "O meu conceito de arquitetura está na união e na colaboração das artes, de tal modo que cada coisa seja subordinada à outra e com essa harmonia (...) É concepção ampla, porque abraça todo o ambiente da vida humana; não podemos nos subtrair da arquitetura, enquanto fizermos parte da civilização, porque ela representa o conjunto das modificações e das alterações realizadas sobre a superfície terrestre, tendo em vista as necessidades humanas" (MOTTA, Flávio. "Art nouveau: um estilo entre a flor e a máquina". In: Cadernos Brasileiros, v. 28, n. 2, mar/ abr 1965, p. 58).

131 Segundo Costa, "toda arte plástica verdadeira há de ser, antes de mais nada, arte pela arte, pois o que a haverá de distinguir das outras manifestações culturais é o impulso desinteressado e invencível no sentido de uma determinada forma plástica de expressão. Quando todos os demais fatores direta ou indiretamente necessários à sua manifestação estejam presentes - inclusive o social - e este impulso desinteressado e invencível faltar, a obra poderá ser documento do que se queira, mas não terá maior significação como arte" (COSTA, L. "Considerações sobre arte contemporânea", 1952. In: XAVIER, Alberto [org]. Lucio Costa: sobre arquitetura. Porto Alegre, UniRitter, 2007, p. 218).

132 Lembremos que esse problema também preocupava Lucio Costa, na década de 1950. Em 1952, o arquiteto chega à definição da "arte pela arte com função social" (Cf. nota 74). Se à primeira vista essa formulação parece ser próxima à arquitetura "artisticamente social" de Habitat, o desenvolvimento de "Considerações sobre arte contemporânea" demonstra que, apesar das preocupações comuns, as premissas e proposições são bastante diferentes. Vejamos: para Costa, a arte moderna poderia ter, na sociedade contemporânea, "uma função social de alcance decisivo, passando a constituir (...) o fundamento mesmo de uma arte vigorosa e pura, de sentido otimista, digna portanto de um proletariado cada vez mais senhor de seu destino". A arte poderia ser um "complemento lógico para compensar a monótona tensão e a rudeza opressiva do trabalho quotidiano nas indústrias", "forma ativa de evasão e reabilitação psicológica individual e coletiva", e, se os novos conceitos de arte fossem aplicados "socialmente" (à maneira do esporte, por exemplo), poderiam devolver à arte a sua raiz popular, conferindo-lhe um "novo conteúdo humano mais rico e sentido plástico diferente". Mas os artistas, "legítimos criadores" de um "mundo à parte e pessoal", se realmente artistas, jamais poderiam abandonar o "impulso desinteressado e invencível no sentido de uma determinada forma plástica de expressão". Como resolver esse impasse, chegando numa arte ao mesmo tempo "social" e "desinteressada" ? Costa propõe, então, que se mobilize os "velhos mestres, criadores geniais de nosso tempo", a fim de se dedicarem ao ensino, um processo que teria a finalidade última de "provocar a participação direta do próprio povo no processo geral da formação de uma consciência artística contemporânea, capaz de produzir por si mesma porta-vozes mais credenciados". A nosso ver, essa proposta "prática" (por assim dizer), é inconsistente e frágil; a premissa da intenção plástica como elemento central, combinada com a leitura do "gênio" enquanto figura-chave (que, nesse texto, se mostra pela definição do artista como um "legitimo criador de um mundo à parte e pessoal" que no fundo cria apenas para si mesmo), acabam deixando-o sem transições ou mediações para pensar a ligação entre arte e sociedade, entre arquitetura e história. (Ibid., p. 216-223). 
Se a técnica é fator fundamental para o fazer artístico, vale lembrar que ela não prescinde da "expressão" do artista - que, para Habitat, não é necessariamente uma expressão individual: pode ser também a expressão da coletividade, daqueles que fazem arte como uma "atividade costumeira da vida". No editorial, fica bastante claro que o que se considera genialidade, em arte, é a "genialidade do país", uma espécie de genialidade coletiva expressa não somente pelo grande artista mas também (e principalmente) pelas manifestações do povo, manifestações de uma arte cotidiana, útil, social enfim ${ }^{133}$.

Tanto a arquitetura como, num âmbito mais geral, a cultura, são orientadas e fundamentadas pelo popular, com seus valores definidores de uma "moralidade de vida"134: a racionalidade construtiva, o respeito às técnicas locais e ao clima, a economia de meios, coerência, sinceridade, simplicidade ${ }^{135}$. A importância da

133 O espaço que a revista reserva ao pensamento de figuras como Walter Gropius e Max Bill (19081994), ambos propagandistas da "função social" da arquitetura e do design, também corrobora esta postura. Habitat 14 (jan/fev 1954) publica a conferência "O arquiteto na sociedade industrial", ministrada por Gropius no IV Congresso de Arquitetos, em janeiro do mesmo ano. Quanto a Max Bill, Habitat 12 republica a sua polêmica entrevista para revista Manchete, sob o título "Max Bill, o inteligente iconoclasta", na qual o artista faz duras críticas ao edifício Califórnia, de Niemeyer, identificando um afastamento da arquitetura moderna brasileira em relação à função e alertando contra o risco de um "academismo moderno". Além disso, a revista publica "Beleza provinda da função e beleza como função" (Habitat 2) e a conferência "O arquiteto, a arquitetura, a sociedade" (Habitat 14), ambos discussões sobre a "função social" da arquitetura e do design modernos.

134 Inclusive, as manifestações (do passado ou atuais) que "contrariam" essa moralidade, entretanto, não devem ser esquecidas, pois são partes da história e podem funcionar como contra-exemplos. Um exemplo interessante é o artigo não assinado "Arquitetura a banquete", constituído de um pequeno texto que discorre sobre o tema das exposições universais e sua arquitetura, acompanhado de várias fotografias dos pavilhões construídos por ocasião da Exposição Nacional de 1908, no Rio de Janeiro - todos eles fantasticamente ecléticos. Uma pequena fotografia contrasta com as restantes, mostrando as tendas de acampamento dos soldados que guardavam exposição: "Ninguém percebeu que a única, verdadeira arquitetura foi aquela das tendas (...) O homem visa o mínimo de arquitetura, que seja lógico, que seja funcional (...) O homem de 1908 se comprazia com a pompa falsa, com o ouropel (...) Mas quais passos foram feitos pelo homem de 1951?" ("Arquitetura a banquete". In: Revista Habitat 3, 54-57).

135 Lembremos que esses valores não são colocados apenas por Habitat: Stuchi aponta como essa "genealogia da casa moderna" se apresenta no contexto italiano do segundo pós-guerra, quando ocorre uma revalorização da tradição e a reconstrução européia passa a ser "pensada não mais 'através da máquina', mas a partir do desenvolvimento de uma série de pesquisas sobre os modos de construir e os hábitos de morar das camadas populares, que demonstram a superação das bases do futurismo e de alguns aspectos da arquitetura racionalista realizada no entre-guerras". A autora vê aí um diálogo entre o discurso arquitetônico italiano - arquitetos e críticos como Lina, Carlo Pagani, Raffaello Carrieri e Bruno Zevi - e as posições de Habitat (STUCHI, F. Revista Habitat: um olhar moderno sobre os anos 50 em São Paulo. São Paulo, FAUUSP (Tese de Mestrado), 2006, p. 96). Seria interessante observar, entretanto, que Habitat e especialmente Lina irão acrescentar a esses valores, alguns outros mais "conflituosos", como a "falta de polidez", a "rudeza" e um "tomar e transformar sem preocupações" - valores ligados às raízes primitivas da nacionalidade, de certo modo antropofágicos, e que determinam a própria consciência da técnica, como veremos mais adiante. 
arte popular e do artesanato (a mão, o trabalho), é a de que eles, mais do que formas, materiais ou situações a serem reproduzidos, são fundamentos para pensar e criar uma cultura nova e brasileira - alimentando inclusive o pensamento do design, que seria uma re-união, em novas bases, da arte com a indústria. A produção moderna não deve apenas ser acessível ao povo (como um gadget da sociedade de consumo, diz Lina): deve "deglutir" o popular, ser popular, incorporar os seus valores.

Assim, nos anos 50, Habitat propõe uma cultura e uma história brasileiras novas, a serem inauguradas. Se Lina, em 1951, caracteriza a arquitetura moderna brasileira pela falta de polidez, a rudeza, um "tomar e transformar sem preocupações" quase antropofágico, destacando o fato dela reunir a "consciência da técnica" e "a espontaneidade e o ardor da arte primitiva" ${ }^{136}$, algumas décadas mais tarde, estenderá essa formulação para a cultura de modo geral ${ }^{137}$ - uma cultura autóctone, autônoma e original, cujas maiores possibilidades estariam justamente na síntese entre moderno e primitivo, novo e antigo, erudito e popular.

O trabalho de revisão histórica de Motta, com a sua busca de estabelecimento de uma funcionalidade para a arte por meio de sua re-ligação com o artesanato e a indústria, a recuperação das relações entre a arte e a esfera do trabalho, assim como do trabalhador no fazer artístico e arquitetônico, podem ser entendidos como parte dessa discussão. Ao recuperar o art nouveau, Motta está especialmente preocupado com um dos pólos da equação, a "consciência da técnica".

A "consciência da técnica" parece ser uma re-proposição da "moral do fazer técnico", tal como expressa na obra de Mário de Andrade da década de 1930. É uma defesa, talvez, de uma produção que supere o artesanato ou a arte popular (formas verdadeiras porém inconscientes de utilização do conhecimento das técnicas e dos materiais) - sem é claro descartá-los enquanto fundamentos da produção contemporânea.

136 BARDI, L. "Bela criança". In: Revista Habitat no. 2, jan/mar 1951, p. 3.

137 Em 1977, ao fazer um balanço da situação brasileira, a arquiteta retoma essa mesma formulação, colocando que o Brasil estava em uma encruzilhada de "opções culturais": escolher entre a finesse ("gadgets, consumo", o caminho da Europa e EUA) e "procura técnico-primitiva duma cultura original" (caminho da África e do Oriente). Conclui que "o Brasil tinha chegado num bívio. Escolheu a finesse" (BARDI, L. "Tempos de grossura", 1977. In: Lina bo Bardi. São Paulo, Instituto Lina bo e P.M. Bardi, 1996, p. 210). 
Por outro lado, essa "consciência" expressa um desejo de atitude crítica face ao funcionalismo - ao qual Motta, Lina e Habitat também se referem usando os termos como "maquinismo", "cientificismo" e "industrialismo"138. Isso porque, na síntese proposta, a indústria, a técnica, o funcional por assim dizer, devem ser antropofagicamente qualificados pela "espontaneidade e ardor da arte primitiva" - que é também popular e coletiva. A grande novidade é que o reconhecimento do saber-fazer tradicional funciona no sentido de uma revisão do saber-fazer industrial - e, assim, a técnica passa a ser vista não mais como solução, mas como problema, estimulo à reflexão acerca das possibilidades, limitações e contradições de um país pobre que se industrializa, fundamento para pensar uma nova cultura ${ }^{139}$.

138 Em Contribuição..., Motta afirma que no século XX a "supremacia da máquina" transforma-se em "uma nova forma de prepotência" que subordina servilmente o natural às determinações da indústria ou artifício, numa relação destrutiva e contrária ao próprio desenvolvimento humano (ou, em suas palavras, contrária à integração homem-mundo). É curioso que, ao fazer essa crítica do maquinismo, Motta cite justamente um discurso do arquiteto Mies van der Rohe (1886-1969), cuja obra nos EUA - como o edifício Seagram, de 1958 - torna-se um símbolo da apropriação das soluções racionais e da técnica moderna enquanto símbolos do poder e do prestígio das grandes corporações norte-americanas. Diz Motta, reproduzindo um trecho de um discurso do arquiteto: "Pode-se dizer que o problema da forma e conteúdo (...) voltou ainda hoje, na 'era maquinista', a preocupar artistas como Mies van der Rohe, que num discurso pronunciado na Escola de Arquitetura do Armours Institute de Chicago em 1938, disse: 'Demonstraremos que a técnica não só promete grandeza e potência, mas também contempla perigos'" (in MOTTA, Flávio. Contribuição ao estudo do art nouveau no Brasil. Tese (cátedra). São Paulo, FAUUSP, 1957, p. 10). A escolha de Motta talvez se esclareça se retomarmos Artigas, que, se por um lado avalia que "os americanos (...) transformaram essa arquitetura do racionalismo e suas expressões, que devem conter em si a esperança de uma ligação da beleza das formas à felicidade humana universal, em expressão de seu próprio poder", por outro o racionalismo mies-van-der-roheiano não deixou de trazer "contribuições da Alemanha social-democrata de tempo de Gropius" - contribuições que revelam "a forma necessária e possível de realizar", "o nível de utilidade", as "formas com um critério de internacionalidade". Assim, Artigas parece reconhecer uma duplicidade nas obras do arquiteto, e defende que "bani-las por causa de um preconceito ideológico seria um absurdo. Elas passam a ser um patrimônio da humanidade, como forma de construir (...) conquista técnica". (ARTIGAS, V. "A função social do arquiteto" - $3^{\text {a }}$ Argüição. In: ARTIGAS, V. Caminhos da arquitetura. São Paulo, CosacNaify, 2004, p. 214-223).

139 A "consciência da técnica" equivale à consciência da técnica num país como o Brasil. Essa formulação que no início dos anos 50 aparece como uma formulação teórica, irá se desenvolver ao nos anos seguintes no plano do projeto arquitetônico, nas obras de Lina e Vilanova Artigas. A partir dessa noção de "consciência da técnica", a arquiteta irá defender a "arquitetura pobre", que orienta, por exemplo, a concepção do projeto do novo edifício do MASP: "Através de uma experiência popular cheguei àquilo que poderia chamar de Arquitetura Pobre. Insisto, não do ponto de vista ético. Acho que no MASP eliminei o esnobismo cultural tão querido pelos intelectuais (e os arquitetos de hoje), optando pelas soluções diretas, despidas. O concreto como sai das formas, o não acabamento, podem chocar toda uma categoria de pessoas. Os painéis didáticos de cristal nos quais são expostos os quadros, não agradam os acostumados ao comodismo dos estofados e dos controles remotos (...)" (BARDI, L. "Museu de arte de São Paulo". In: Lina bo Bardi. São Paulo, Instituto Lina bo e P.M. Bardi, 1996, p. 100). A arquitetura de Artigas, por sua vez, será muitas vezes identificada como "brutalista"; independentemente das discussões que hoje se realizam sobre a adequação do termo à sua obra, não podemos deixar de notar a proximidade conceitual e projetual entre pobreza e brutalidade: Lina e Artigas têm em comum a valo- 
rização da dimensão cultural e coletiva da arquitetura, e uma busca de retorno a um popular primitivo e rude - remetendo, de certa forma, à "ausência total do individuo mas com a presença do ser humano", característica comum ao folclore e à nascente arquitetura moderna, segundo Mário de Andrade. É justamente nisso que parece residir a sua "superação do funcionalismo", que é diferente da superação defendida por Lucio Costa e construída por Niemeyer - que irão colocar a expressão plástica do artista (individualmente) como elemento central (ou, ao menos, ponto de partida) para a superação da "rudeza e monotonia do trabalho mecanizado imposto pelas técnicas modernas de produção" (COSTA, L. "Considerações sobre arte contemporânea", 1952. In: XAVIER, Alberto [org]. Lucio Costa: sobre arquitetura. Porto Alegre, UniRitter, 2007, p. 223). 



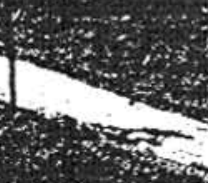

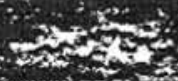

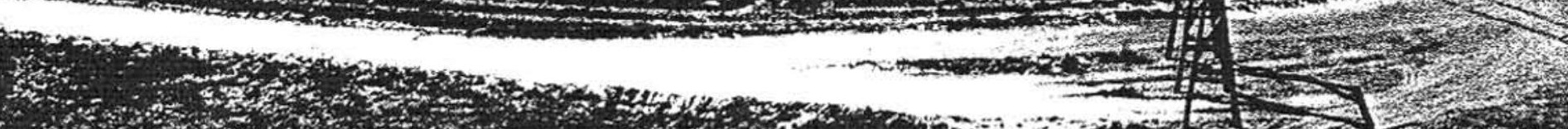

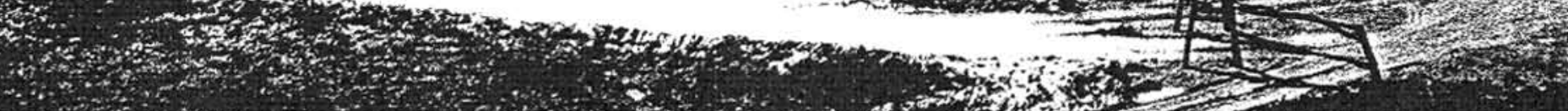


fig 7 [página anterior]

Vista aérea do Eixo Monumental

de Brasília no início da construção

por Marcel Gautherot 


\section{a história num impasse: "introduzione al brasile"}

O texto "Introduzione al Brasile", de 1960, pode ser considerado como o corolário do processo crítico-reflexivo de reconstrução da história realizado por Flávio Motta nos anos anteriores. Nesse panorama geral da arquitetura e das artes brasileiras, direcionado ao público europeu, são feitas novas sínteses, em relação à de "400 anos..." e aos textos sobre o art nouveau. Agora, estão mais claramente definidos os pontos de vista do autor; as motivações para a escolha do período da Primeira República e de São Paulo como momentos privilegiados de análise; a sua interpretação acerca do surgimento do modernismo e da arquitetura moderna no Brasil, e as considerações acerca de seu desenvolvimento e perspectivas; e, finalmente, as expectativas em relação ao papel do artista, do arquiteto e do intelectual. Além disso, "Introduzione" permite vislumbrar as primeiras contradições e impasses decorrentes da tentativa de se colocar no centro da "revisão histórico-crítica" a industrialização e a burguesia como seu agente fundamental.

O texto é publicado em italiano, na revista Zodiac número 61', como introdução ao Rapporto Brasile ("relatório sobre o Brasil"), uma espécie de dossiê sobre a arquitetura moderna brasileira. Além do texto de Motta, o Rapporto conta com uma breve apresentação escrita pelo editor-chefe Bruno Alfieri, perfis dos arquitetos Afonso Eduardo Reidy (1909-1964), Rino Levi (1901-1965), Vilanova Artigas, Marcelo (1908 - 1964) e Maurício Roberto (1921-1996) e do paisagista Roberto Burle Marx (1909-1994)², um texto do crítico italiano Bruno Zevi (1918-2000) so-

1 Zodiac nasce em 1957, publicada pelas Edizioni di Comunità em italiano, inglês e francês. Tendo Bruno Alfieri (1927-2008) como editor-chefe, inicialmente contou com um comitê editorial composto pelo engenheiro e político Adriano Olivetti (1901-1960) e outras figuras importantes como Giulio Carlo Argan (1909-1992). Dentre seus colaboradores destacam-se Siegfried Giedion, Henry-Russell Hitchcock (19031987), Ernesto Rogers (1909-1969), Eero Saarinen (1910-1961), Paolo Portoguesi (1931) e Le Corbusier. O diretor de arte é Roberto Sambonet (1924-1995), arquiteto, pintor e designer que mora no Brasil de 1948 a 1953, colaborando com Pietro e Lina Bardi nas atividades do MASP e tornando-se amigo de Flávio Motta; é Sambonet quem indica o seu nome para escrever a introdução (COSTA, J. B. "Rapporto Brasile: arquitetura brasileira na revista Zodiac, 1960", s.n.).

2 Esses perfis são de autoria de Alfieri, Giulia Veronesi e Pietro Porcinai. Segundo o editor, a escolha dos arquitetos foi feita apenas por "conveniência", e outros nomes como "Sergio Bernardes, Giancarlo Palanti, Henrique Mindlin, Lucio Costa e Oswaldo Bratke", ou mesmo "as obras recentes de Oscar Niemeyer" (excetuadas as de Brasília) poderiam ter constado no Rapporto. 
bre Brasília3, e artigos de dois brasileiros: o célebre "Depoimento" de Niemeyer, escrito em 1958, e "Ponto de vista de um brasileiro", de Mário Barata (19212007).

Não por acaso, o dossiê é publicado no ano de 1960. Segundo o editor, Zodiac há tempos tinha a intenção de realizar uma reportagem especial sobre a arquitetura brasileira; a transferência da capital do Rio de Janeiro para Brasília, em 1960, mostra-se como a ocasião ideal ${ }^{4}$. A revista demonstra ter um posicionamento crítico em relação ao projeto de Brasília, alinhando-se às posições de Zevi ${ }^{5}$; no entanto, também cede espaço aos defensores do projeto - insistindo na importância de que a nova capital, e a arquitetura moderna brasileira de modo geral, fossem entendidos e interpretados na "realidade social, econômica e cultural" brasileira e internacional.

Os "pecados" de Niemeyer e Lucio Costa em Brasília (que, pelas colocações da revista, parecem se relacionar principalmente à tendência à monumentalidade da nova capital) devem ser lidos em relação ao conjunto de suas obras, e "enquadrados, de resto, em um processo geral de decorativismo que está difundindo-se em muitos países e sobretudo nos Estados Unidos, um processo que tem sérios

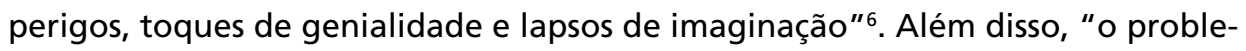

3 O texto de Zevi em Zodiac, "Critica a Brasilia", é baseado em um artigo ("Inchiesta su Brasília") anteriormente escrito pelo autor e publicado na sua revista L'Architettura Cronache e Storia , número 9, em janeiro de 1960.

4 Lembremos que um ano antes, em 1959, tinha ocorrido o Congresso Internacional Extraordinário de Críticos de Arte, nas cidades de São Paulo, Rio de Janeiro e Brasília. Inúmeros críticos, arquitetos, artistas e outras personalidades participaram do evento (que no Brasil foi organizado por Mário Pedrosa e Mário Barata): entre outros, Motta, Alfieri e Zevi (segundo Pedrosa, o enfant terrible do congresso, por suas posições extremamente críticas a Brasília) - para nos restringirmos apenas aos que colaboram no Rapporto de Zodiac.

5 "Inchiesta su Brasília", texto de Zevi que serve de base ao artigo publicado em Zodiac, é segundo o autor uma "homenagem" a Lucio Costa e Oscar Niemeyer, "generosos protagonistas da aventura de Brasília". Isto não impede, entretanto, que o projeto seja fortemente criticado, em seis pontos principais: "1) [Brasília] é produto de uma decisão política, de um ato paternalista, e corre o risco de não se tornar uma cidade e sim um cenário caro e de pouca utilidade; 2) o plano da cidade possui tanto os defeitos do contemporâneo 'plano aberto' quanto aqueles do 'plano fechado' do século XIX. Baseia-se em uma cruz, que estrangula o desenvolvimento do centro urbano; 3) os conjuntos residenciais são indiferenciados, não possuem uma clara articulação figurativa; 4) o enfoque do centro cívico é de inspiração clássica, de forma que todos os edifícios se tornam 'monumentos'; 5) a arquitetura funcional é fria e anônima; 6) a arquitetura dos edifícios públicos é retórica e caprichosa, com suas estruturas de formas recortadas e ausência total de pensamento espacial. Brasília é uma cidade kafkiana, o paraíso dos burocratas. Se a vida entrar ali, transformará o plano piloto e os monumentalismos pseudo-modernos serão destruídos" (ZEVI, B. "Inchiesta su Brasilia". In: L'Architettura Cronache e Storia, no. 9, jan. 1960, p. 608).

6 Na versão original: "I peccati di Costa e di Niemeyer sono forse peccati veniali, posti in rapporto alla realtà della loro produzione più vitale, e inquadrati, del resto, in un generale processo di arricchimento decorativo 
ma de Brasília" também poderia ser esclarecido por meio da leitura das obras de outros artistas e arquitetos atuantes "na viva realidade econômica e cultural do país", como por exemplo Rino Levi e Artigas (este último, "um arquiteto ligado aos temas da cultura e de uma rara sensibilidade plástica" $\left.{ }^{7}\right)^{8}$.

Assim, o Rapporto de Zodiac - procurando abarcar as diferentes orientações adotadas pelos arquitetos brasileiros e valorizando a dimensão cultural da arquitetura - diferencia-se da grande maioria das edições especiais sobre o Brasil publicadas por revistas estrangeiras ${ }^{9}$. Essas edições em geral priorizaram a arquitetura do grupo carioca, inaugurada com o edifício do Ministério da Educação, fazendo muitas vezes uma "crítica apologética"10 e superficial da produção arquitetôni-

che sta diffondendosi in molti paesi e soprattutto negli Stati Uniti, non senza gravi incognite e pericoli, con punte di genialità e vuoti di fantasia" (ALFIERI, B. "Rapporto Brasile". In: Revista Zodiac, no. 6, p. 58).

7 ALFIERI, B. "Rapporto Brasile". In: Revista Zodiac, no. 6, p. 58.

8 É curioso que Zodiac não mencione o nome de Lina bo Bardi. A arquiteta, em 1960, já tinha dirigido Habitat, acompanhava a construção do novo edifício do MASP (um projeto seu), participava ativamente da vida cultural em São Paulo e Salvador. Muitas de suas posições são próximas às de Zodiac e a de críticos como Argan (cf. notas 49 e 59 deste capítulo), mas, em relação ao "monumentalismo" especificamente, as opiniões divergem. Alfieri considera que o "monumentalismo" de Brasília, embora "justificável" politicamente, estaria presente também nos planos técnico e cultural, implicando em "uma tradução em símbolos artificiais de componentes extra-artísticos" (Ibid.). Para Lina, a noção de monumental é posta em questão, assumindo um outro sentido: "Na projetação do Museu de Arte de São Paulo (...) procurei uma arquitetura simples, uma arquitetura que pudesse comunicar de imediato aquilo que, no passado, se chamou de 'monumental', isto é, o sentido do 'coletivo', da 'Dignidade Cívica'" (BARDI, L. "Museu de Arte de São Paulo". In: Lina bo Bardi. São Paulo, Instituto Lina bo e P.M. Bardi, 1996, p. 100).

9 Em meados do séc. XX, especialmente a partir de 1943 (ano da exposição Brazil Builds), a arquitetura moderna brasileira começa a ganhar um grande espaço nas publicações especializadas. Segundo Costa, de 1943 até 1960 são vinte números especiais dedicados exclusivamente à produção nacional, sem contar as centenas de artigos e reportagens "avulsos" que passam a aparecer com regularidade nas revistas estrangeiras (COSTA, J. B. "Rapporto Brasile: arquitetura brasileira na revista Zodiac, 1960", s.n.). Dentre as motivações para tamanho interesse pela arquitetura moderna brasileira, Miranda indica, na década de 1950, uma "situação de revisão cultural" do moderno, quando as "prerrogativas universalistas" antes defendidas são substituídas por novas elaborações crítico-projetuais - elaborações que, em oposição ao international style, pretendem abarcar manifestações regionais e aproximar-se do vernacular. Nesse sentido, a produção brasileira é exemplar, sendo considerada por alguns críticos como "um dos primeiros estilos nacionais da arquitetura moderna" (MIRANDA, C. L. A crítica de arquitetura nos anos 50, a expressão plástica e a síntese das artes. São Carlos, EESC-USP (Dissertação de Mestrado), 1998, p. 205).

10 Para Miranda, essa "crítica apologética" teria lugar especialmente nas revistas francesas como a Architecture D'Aujourd'hui; já as revistas inglesas e italianas (dentre as quais a Architectural Review, a Casabella e a própria Zodiac) adotariam um posicionamento mais crítico frente à arquitetura brasileira, contando com a colaboração de críticos como Nikolaus Pevsner e Bruno Zevi (Op. cit., p. 202). Lembremos que em 1952 o próprio Artigas já notava essa tendência "apologética" das revistas: para o arquiteto, as revistas francesas de urbanismo e arquitetura, ao publicar fotos das escolas modernas brasileiras, se esqueceriam de dizer "que o Brasil é um país de 70\% de analfabetos" - e que, por isso, a escola de cuja fotografia se utilizam seria "um instrumento para iludir nos outros países as pessoas honestas", a "arquitetura a serviço da mentira" (ARTIGAS, V. "Os caminhos da arquitetura moderna", 1952. In: Caminhos da arquitetura. São Paulo, Fupam/ Cosacnaify, 1999, p. 39). 
ca brasileira - contribuindo assim efetivamente para a constituição da chamada "trama dominante" da historiografia do movimento moderno brasileiro.

O papel de "Introduzione al Brasile", no Rapporto, é situado da seguinte maneira por Bruno Alfieri:

Como introdução ao nosso rapporto publicamos um artigo de Flávio Motta, brasileiro, que bem esclarece os limites dentro dos quais devemos enquadrar um juízo qualitativo [da arquitetura moderna brasileira]. O Brasil sempre precisa ser esclarecido, desde os tempos de Jean-Baptiste Debret e sua Viagem pitoresca ao Brasil.11

O caráter introdutório do texto, no entanto, parece valer não apenas para o público italiano ou europeu; na medida em que Motta ajuda a sintetizar uma posição dissonante em relação às tendências majoritárias da historiografia da arquitetura brasileira, a sua "introdução ao Brasil" -resultado do trabalho de "revisão histórico-crítica" desenvolvido pelo autor ao longo da década de 1950 poderia talvez ser considerada como novidade para os próprios brasileiros.

Com a proposta de abordar a arquitetura brasileira a partir da formação histórica do Brasil (evitando, assim, os "costumeiros juízos formalistas" acerca da arquitetura brasileira), a perspectiva geral de "Introduzione..." é a "obtenção de uma forma plena da Nação", uma forma que permita a superação da "nação feita a partir de uma teoria política" ${ }^{12}$. Esta perspectiva nacionalista - que, segundo Motta, aponta para um problema "caracteristicamente político" -, embora de-

11 Na versão original: "Come introduzione al nostro rapporto pubbliachiamo um articolo di Flavio Motta, brasiliano, che ben chiarisce i limiti entro i quali inquadrare un giudizio qualitativo complessivo. II Brasile necessita sempre di chiarimenti, sin dai tempi di Jean-Baptiste Debret e del suo 'Viagem pitoresca ao Brasil"" (ALFIERI, B. "Rapporto Brasile". In: Revista Zodiac, no. 6, p. 58).

12 Em tal "nação feita a partir de uma teoria política", as "tradições dinásticas" se sobreporiam às "aspirações populares", segundo a formulação de Euclides da Cunha (1866-1909) que é retomada por Motta: "Basta recordarmos o que dizia Euclides da Cunha em seu livro À margem da história, ao início do século: 'Somos o único caso histórico de uma nação feita a partir de uma teoria política. Passamos de um só golpe da homogeneidade da colônia ao regime constitucional, dos beneplácitos reais às leis. E entrando de improviso na órbita de nossos destinos, o fizemos com o único equilíbrio possível naquela época: o equilíbrio dinâmico entre as aspirações populares e as tradições dinásticas'". É interessante notar que Cunha está se referindo ao período imperial, quando, no entender de Motta, as "tradições dinásticas" foram "os principais determinantes da unidade nacional". Motta não considera que a República brasileira seja uma construção problemática, ou artificial, na medida em que avalia que este regime traz grandes avanços no plano da economia e é concomitante a uma "gradual autonomia das forças populares": "as aspirações populares, inicialmente identificadas com a causa da independência e do Imperador, tiveram que (...) se desenvolver através de formas liberais até a República" (MOTTA, F. "Introdução ao Brasil", 1960. Trad. J. B. Costa. In: COSTA, J. B. Ver não é só ver: dois estudos a partir de Flávio Motta. São Paulo, FAUUSP (Dissertação de Mestrado), 2010, p. 201). 

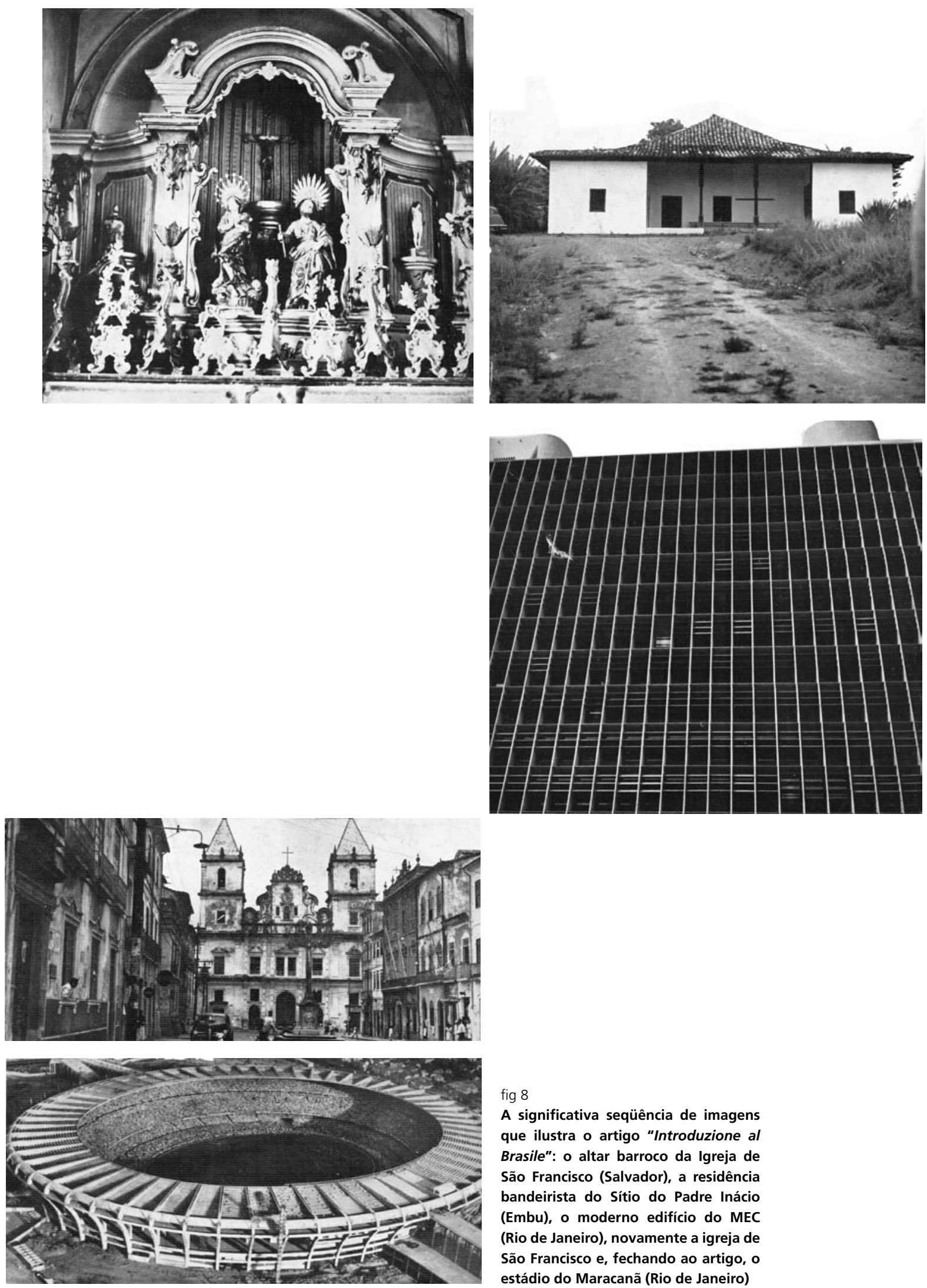

fig 8

A significativa seqüência de imagens que ilustra o artigo "Introduzione al Brasile": o altar barroco da Igreja de São Francisco (Salvador), a residência bandeirista do Sítio do Padre Inácio (Embu), o moderno edifício do MEC (Rio de Janeiro), novamente a igreja de São Francisco e, fechando ao artigo, o estádio do Maracanã (Rio de Janeiro) 
terminante para o trabalho de reconstrução histórica, nunca havia sido expressa com tanta clareza nos textos anteriores do autor.

A busca de uma "forma plena da Nação", em 1960, recoloca o problema da formação, com o qual intelectuais e artistas vinham se debatendo desde meados da década de 1920 - e mostra um reconhecimento de que, apesar de todos os avanços, a nacionalidade não havia sido atingida plenamente. Assim, Motta problematiza a análise das manifestações culturais (entre elas a arquitetura moderna), ao relacionar a sua possibilidade de sucesso, e mesmo de sobrevivência, ao desenvolvimento econômico e industrial nacional.

Para o autor, a formação histórica do Brasil seria marcada pelo paralelismo entre o desenvolvimento econômico e um processo de crescente "caracterização cultural" do país - processo este ligado a uma "gradual autonomia das forças populares". Assim, embora durante a Colônia o Brasil já tivesse começado a "caracterizar-se culturalmente" ${ }^{13}$, seriam o Império (1822-1889) ${ }^{14}$ e principalmente a República Velha os grandes momentos da "unidade nacional" - e neles, portanto, é que deveriam ser situadas as primeiras possibilidades de "integração cultural" da nação.

\subsection{A centralidade da República e de suas manifestações culturais}

A Primeira República - "fase econômica da unidade nacional" - ocupará posição central em "Introduzione al Brasile". Como vimos, essa centralidade já era afirmada em textos anteriores, mas agora os fundamentos dessa valorização, e também as suas conseqüências, serão melhor esclarecidos.

O significado substancial dessa nova etapa corresponde a aquilo que enunciava Euclides da Cunha: 'A nossa evolução, por ser estritamente política, era problemática. Pelo menos ilusória. Estava numa minoria educada à européia. O resto permanecia nas mesmas condições nas quais a metrópole o havia deixado: obscuro amálgama proteiforme de brancos, negros e indígenas (...)'. ${ }^{15}$

13 No período colonial, Motta destaca a arquitetura como um exemplo dessa "caracterização cultural" que apenas se iniciava; a arquitetura, apesar da influência portuguesa, já manifestaria a emergência de uma "linguagem própria", seja no emprego de novas técnicas construtivas, seja na organização espacial ou nas "peculiares formas barrocas de sua ornamentação" (MOTTA, F. "Introdução ao Brasil", 1960. Trad. J. B. Costa. In: COSTA, J. B. Ver não é só ver: dois estudos a partir de Flávio Motta. São Paulo, FAUUSP (Dissertação de Mestrado), 2010, p. 203).

14 Com o Império, "grande fase política" da unidade nacional, o Brasil conhece novas condições de mercado e novas possibilidades para a vida artística e literária - dentre elas, o surgimento da imprensa, a vinda da Missão Francesa em 1816 e emergência do neoclassicismo. O neoclassicismo coloca o problema do ensino artístico - central para Motta - e impõe "'cânones' que, mesmo não correspondendo às exigências latentes das formas espontâneas de expressão brasileiras, provocaram um progresso qualitativo". A cidade do Rio de Janeiro centraliza a vida cultural e, assim como a Academia, serve "aos ideais de unidade do Império" (Ibid.).

15 Ibid., p. 203. 
O significado da República Velha, na opinião de Motta, é a possibilidade por esta colocada da construção de uma "unidade civilizadora" brasileira, que permitisse ao Brasil chegar "a uma fisionomia própria no quadro da civilização":

\begin{abstract}
As estradas desse desenvolvimento econômico se tornaram tortuosas. Entre outras coisas, a monocultura do café foi um grande obstáculo à industrialização, mesmo quando ela parecia irrefreável. Se não fosse pela identificação entre as exigências econômicas gerais e a maior parte da população, desejosa de consolidar uma atmosfera criativa, seria ainda hoje problemático esse desenvolvimento. Não se trata aqui portanto, no caso do Brasil, de traçar um esboço do perfil nacional, como reflexo de uma demonstração de força, prestigio e poder econômicos, mas sobretudo, como uma tentativa de salvaguardar um modus vivendi, um tipo de civilização, uma organização isenta de preconceitos raciais; uma civilização atada aos problemas humanísticos da latinidade; uma civilização que tem tanto da européia, como da indígena, asiática, africana, norte-americana e católica. É nesta ebulição, nesta fermentação de impulsos tão contraditórios, que se aguça a sensibilidade política do homem brasileiro, desejoso de encontrar uma formula superior de integração cultural. O fenômeno da industrialização, as conquistas da técnica e da ciência, são aqui destinadas a diluir-se nos interesses por esse tipo de unidade civilizadora. Ontem, na simbologia de um Império; hoje, na realidade contingente de um povo, para chegar a uma fisionomia própria no quadro da civilização. ${ }^{16}$
\end{abstract}

Emergem agora alguns problemas importantes na leitura que Motta faz do período republicano. A sua revisão irá adquirir, progressivamente, um sentido cada vez mais culturalista e "ilustrado"17. Não discute ou aponta o real significado político da república (até que ponto o regime era "democrático", e se havia efetiva participação popular, por exemplo); o desenvolvimento econômico por ela representado, embora apontado como problemático e tortuoso, já que associado à agricultura (e à monocultura cafeeira), é redimido por uma explicação imprecisa acerca da "identificação da maior parte da população" com as "exigências econômicas gerais".

Apresentando os antecedentes da "instalação pacifica" do novo regime - que conformariam um "clima de interesse na força produtiva e cultural" -, Motta irá destacar o governo do Visconde do Rio Branco (1871 a 1875) - que lança, no fim do período imperial, as bases da educação pública, profissional e superior, cria

16 MOTTA, F. "Introdução ao Brasil", 1960. Trad. J. B. Costa. In: COSTA, J. B. Ver não é só ver: dois estudos a partir de Flávio Motta. São Paulo, FAUUSP (Dissertação de Mestrado), 2010, p. 202.

17 Usamos a palavra, aqui, no sentido da expressão "ideologia ilustrada", com a qual Antonio Candido explica o pensamento típico de escritores e intelectuais do século XIX e primeiras décadas do séc. XX, para os quais "a instrução traz automaticamente todos os benefícios que permitem a humanização do homem e o progresso da sociedade. A princípio, instrução preconizada apenas para os cidadãos, a minoria onde se recrutavam os que partilhavam das vantagens econômicas e políticas; depois, para todo o povo, entrevisto de longe e vagamente, menos como realidade do que como conceito liberal" (CANDIDO, A. "Literatura e subdesenvolvimento", 1970. In: A educação pela noite e outros ensaios.

São Paulo, Ática, 1989, p. 140-162). 
escolas politécnicas, constrói ferrovias, realiza as primeiras pesquisas estatísticas, além de quadruplicar a imigração ${ }^{18}$ - e também o pensamento de Ruy Barbosa, considerado por Motta exemplar no sentido de associar educação pública (em especial, o ensino do desenho) e "progresso industrial" 19. Cita o "Parecer sobre o ensino primário", de 1882:

Criar uma consciência industrial: eis a fórmula racional do único estímulo eficaz à industrialização do país (...) Se este ensinamento atinge tais resultados, isto é principalmente ao culto racional, metódico, ramificado em numerosas instituições, do desenho industrial. ${ }^{20}$

\author{
As mudanças ocorridas durante a Primeira República - dentre elas, as "crescentes \\ trocas com outros países, o incremento da imigração, as premissas do movimento
}

18 MOTTA, F. "Introdução ao Brasil", 1960. Trad. J. B. Costa. In: COSTA, J. B. Ver não é só ver: dois estudos a partir de Flávio Motta. São Paulo, FAUUSP (Dissertação de Mestrado), 2010, p. 201-202.

19 Como se vê, Motta tem grande admiração por essas grandes figuras do "liberalismo" brasileiro e por suas defesas da educação pública, deixando, por vezes, de tomar uma distância crítica em relação a esses projetos. Em relação à questão do ensino, Candido mostra bem como há uma espécie de continuidade entre os pensadores da "consciência ilustrada" e parcelas da intelectualidade progressista da década de 1930 - como Francisco Campos ou Fernando de Azevedo (1894-1974) - todos acreditando fortemente na educação como elemento de transformação pacífica da sociedade. Diz Candido: "os ideais dos educadores, desabrochados depois de 1930, pressupunham de um lado a difusão da educação elementar que, conjugada ao voto secreto (...), deveria formar cidadãos capazes de escolher bem seus dirigentes; de outro lado, pressupunham a redefinição e o aumento das carreiras de nível superior, visando renovar a formação das elites dirigentes e seus quadros técnicos (...) não era uma revolução educacional, mas uma reforma ampla, pois no que concerne ao grosso da população a situação pouco se alterou. Nós sabemos que (ao contrário do que pensavam aqueles liberais) as reformas na educação não geral mudanças essenciais na sociedade, porque não modificam a sua estrutura" (CANDIDO, A. "A Revolução de 30 e a cultura". In: Novos estudos CEBRAP, v.2, 4, abr. 1984, p. 28).

20 MOTTA, F. Op. cit., p. 202, Grifo nosso. A referência a Ruy Barbosa é uma constante no trabalho de Motta, e não por acaso. Como mostra Cláudio Amaral, o escritor e político brasileiro está entre os primeiros a defender um projeto de industrialização para o Brasil, no qual a educação pública e o ensino do desenho ocupam posições centrais. O desenho, para Barbosa, significava não apenas uma possibilidade de tornar o ensino mais concreto (a educação "da mão e do olho" em oposição ao usual "culto da frase"), como contribuiria para a superação da separação entre as "artes liberais" ("artes do gosto" e do luxo, segundo Barbosa) e as "artes mecânicas", fundindo-as no que ele conceitua como "artes industriais", fundamentais ao progresso da nação. A união da arte com a indústria, por meio da educação, cumpriria assim a "missão" de "civilizar os agrestes, e dispensar pelos lares (...) a benção e a riqueza do gozo útil e da ornamentação simples"; representaria "um dos auxiliares mais eficazes no nivelamento crescente das distinções de classes entre os homens, não deprimindo as superioridades reais, mas destruindo as inferioridades artificiais (...) elevando cada vez mais alto a ação e o pensamento operário". Trazendo a "igualdade moral" entre os homens, o ensino industrial seria também um importante instrumento contra as "loucuras socialistas" e os "ódios inspiradores da subversão revolucionária": "A democracia quase não existe entre nós, senão nominalmente; porque as forças populares, pela incapacidade de um sistema de educação nacional, estão de fato mais ou menos excluídas do governo. O ensino industrial, porém, infalivelmente inaugurará a iniciação delas na obra política do Estado. Certamente, a arte é a mais poderosa propagadora de paz" (AMARAL, C. "Rui Barbosa e John Ruskin: a política do ensino do desenho". Disponível em <www.vitruvius.com.br/revistas/read/arquitextos/10.121/3467> Acesso em 25/08/2010). 
industrial, as novas forças produtivas" - passam a exigir, no âmbito da cultura, uma "nova revisão fundamental", cujo marco está, segundo Motta, nos abalos sofridos pela Academia de Belas Artes, no Rio de Janeiro. A Academia, antes sustentada pelo imperador, parece "vacilar com o novo regime"; críticos como Araújo Viana demonstram preocupações com o desenvolvimento de uma arte nacional e com o emprego das novas técnicas no âmbito da arquitetura; inicia-se uma reação ao "ecletismo dos neos", avaliada por Motta como "um fator positivo ao início da República"21.

A partir daí, o desenvolvimento cultural brasileiro é apresentado como uma espécie de linha de continuidade - cujo movimento principal está nas diferenças entre Rio de Janeiro e São Paulo. Não há rupturas entre as primeiras reações aos estilos historicistas - dentre as quais o art nouveau e o neocolonial - e o modernismo, seja ele o de 22, seja a antropofagia, seja a arquitetura moderna de Lucio Costa e outros intelectuais.

O autor faz um breve resumo de seus estudos anteriores, destacando a novidade representada por São Paulo 22 e expondo como o "esquema federalista"23 da República Velha irá animar as forças econômicas regionais:

A autonomia crescente descobria as peculiaridades das províncias. São Paulo, entre elas, graças ao café, à imigração e à industrialização, recebeu um impulso particular. Aqui os liberais propunham soluções fisiocráticas para a industrialização. Ampliavase o ensinamento técnico e profissional, onde a arquitetura era apêndice da engenharia. No Rio de Janeiro, ao contrário, o ensinamento da arquitetura era integrado às belas-artes. Mas, ainda em São Paulo, o ensinamento das outras artes plásticas girou na órbita do "Liceu de artes e ofícios", onde proliferavam as primeiras mani-

21 MOTTA, F. "Introdução ao Brasil", 1960. Trad. J. B. Costa. In: COSTA, J. B. Ver não é só ver: dois estudos a partir de Flávio Motta. São Paulo, FAUUSP (Dissertação de Mestrado), 2010, p. 203.

22 O papel de São Paulo no desenvolvimento cultural nacional, sempre destacado por Motta, pode ser relacionado às colocações de Mário de Andrade em 1942 - quando o modernista defende que, "socialmente falando", o modernismo só poderia "ser importado por São Paulo e arrebentar na província": "São Paulo era espiritualmente muito mais moderna porém, fruto necessário da economia do café e do industrialismo conseqüente. Caipira de serra acima, conservando até agora um espírito provinciano servil, bem denunciado pela sua política, São Paulo estava ao mesmo tempo, pela sua atualidade comercial e sua industrialização em contato mais espiritual e mais técnico com a atualidade do mundo" (ANDRADE, M. "O movimento modernista", 1942. In:

Aspectos da literatura brasileira. Belo Horizonte, Itatiaia, 2002, p. 258). Também Antonio Candido se detém na questão, quando aponta que, na literatura, Romantismo e Modernismo, tendo adquirido "tonalidades especificamente paulistanas", são responsáveis por algumas das "mais altas realizações artísticas" brasileiras; são "dois momentos paulistanos (...) dois momentos em que a cidade se projeta sobre o país, e procura dar estilo às aspirações do país todo" (CANDIDO, A. "A literatura na evolução de uma comunidade". In: . Literatura e sociedade. São Paulo, Nacional, 1965, p. 180-199 apud ARRUDA, M. A. Metrópole e cultura: São Paulo no meio do século XX. São Paulo, Edusc, 2001, p. 23).

23 MOTTA, F. Op. cit., p. 204. 
festações do art nouveau brasileiro. No Rio, a Academia retardava esse processo. É em São Paulo que o arquiteto Victor Dubugras, evoluindo do "neogótico" ao art nouveau, retoma os valores de origem, tornando-se o porta-bandeira do "neocolonial brasileiro", que nasce na época da primeira guerra mundial, durante um período no qual a industrialização insuficiente não correspondia mais à exigência de desenvolvimento total da nação. No caso especifico, Victor Dubugras terminará seus dias construindo segundo o estilo "neocolonial brasileiro" para famílias abastadas no Rio. Se configura desta forma, nos primeiros anos da República, o caráter "doméstico" do movimento paulista, com o indispensável "artes e ofícios" seguindo a moda, a bem dizer, dos bons liberais britânicos. ${ }^{24}$

Em São Paulo, o modernismo de 1922 reúne os intelectuais "menos sujeitos ao paternalismo rigoroso e tenaz dos plantadores de café", figuras como Mário de Andrade, preocupadas com a realização de uma cultura brasileira e ao mesmo tempo "investigadores das mais avançadas realizações da arte européia". Embora no terreno da arquitetura as manifestações sejam "mais esporádicas", Motta destaca os nomes de Warchavchik (que em 1925 lança o "Manifesto da arquitetura funcional" e em 1928 "constrói a primeira residência moderna em São Paulo"), Rino Levi (que faz "um apelo por uma política de urbanização") e Flávio de Carvalho (que em 1927 "escandaliza o público com um projeto moderno para o palácio de governo") $)^{25}$.

Ainda no decênio de 1920, lembra do "Movimento Antropofágico" como uma "visão grandiosa e sincretizante do país", que, com personagens como Macunaíma, apontaria para a "coexistência da mutabilidade indígena com a civilização". A partir desse momento, o movimento de 22 passaria da esfera local àquela nacional: “Era, no âmbito da cultura, quase uma antecipação da Revolução de 30, que sacudiu as fundações da República" ${ }^{26}$.

Na década de 1930,

O Brasil mergulhou em direção àquela ditadura "iluminada" que durou até a segunda guerra mundial. Mas conquistou uma legislação social avançada e uma indústria de base. Reforçou o poder central. Sufocaram-se as agitações regionais. O Rio de Janeiro retoma o timão das principais manifestações culturais.

Dentre essas manifestações culturais que se concentram no Rio de Janeiro, Motta menciona a pintura, a literatura, a etnografia, a sociologia ${ }^{27}$ e, especialmente, a arquitetura moderna, um movimento que se delineia com rapidez:

24 MOTTA, F. "Introdução ao Brasil", 1960. Trad. J. B. Costa. In: COSTA, J. B. Ver não é só ver: dois estudos a partir de Flávio Motta. São Paulo, FAUUSP (Dissertação de Mestrado), 2010, p. 204.

$25 \mathrm{lbid}$.

26 Ibib., p. 205.

27 lbid. 
Em São Paulo já havia se manifestado; e no Rio, as crescentes realizações anti-acadêmicas, terminaram por transformar o gosto pelo "neo-colonial" no interesse por uma arquitetura brasileira, "brasileira" não tanto em seus aspectos formais e ornamentais, quanto em seus valores de estrutura, função e outros atributos que pareciam inerentes à tradição arquitetônica. É isto, em grande parte, mérito de Lucio Costa. Sua obra realizou-se na contínua meditação e confronto com os outros vertentes da arquitetura contemporânea".28

O "acolhimento oficial" dos novos valores - que, segundo Motta, se dá por meio da influência de intelectuais como Mário de Andrade, Rodrigo Melo Franco de Andrade (1898-1969) e Carlos Drummond de Andrade (1902-1987) na esfera estatal, também contribui para o "desenvolvimento das mais expressivas e concretas manifestações da arquitetura brasileira contemporânea". A presença de Le Corbusier é apontada como fator determinante para a orientação da arquitetura brasileira, já que o arquiteto cumpriria "a missão de um perfeito propagandista, um mestre que entusiasmava a juventude com a sua exuberante força criativa e doutrinária" 29.

\subsection{Limites e contradições da "revisão histórico-crítica"}

O percurso de "Introduzione al Brasile" não se interrompe na década de 1930, até porque a intenção do autor é discutir a formação histórica do país tendo em vista a atualidade e perspectivas futuras. Mas, conforme avança a exposição - com a retomada do desenvolvimento pós-1930 da arquitetura brasileira, da parceria entre Niemeyer e Joaquim Cardoso (1897-1978) à atuação de Artigas, da organização profissional dos arquitetos e fundação de novas escolas de arquitetura à construção de Brasília -, vão ficando também mais claros os limites e contradições de seu projeto de "revisão histórico-crítica".

No texto, Motta aproxima-se do ideário nacional-desenvolvimentista ${ }^{30}$, com posições que durante décadas foram compartilhadas por parte importante do meio

28 MOTTA, F. "Introdução ao Brasil", 1960. Trad. J. B. Costa. In: COSTA, J. B. Ver não é só ver: dois estudos a partir de Flávio Motta. São Paulo, FAUUSP (Dissertação de Mestrado), 2010, p. 205.

29 lbid.

30 O nacional-desenvolvimentismo foi uma força político-ideológica que expressou, especialmente a partir da década de 1940, os anseios modernizadores de parte da burguesia nacional. Baseava-se na defesa do desenvolvimento brasileiro por meio de industrialização fortemente amparada pelo Estado - que, longe de ser mero administrador e regulador, deveria participar diretamente da produção (por meio da concessão de crédito e subsídios, da criação da infra-estrutura necessária às atividades urbano-industriais e da proteção tarifária contra a concorrência estrangeira). Obteve apoio social para além da própria burguesia industrial, aglutinando setores de classe média urbana, parte da intelectualidade, do proletariado e das Forças Armadas. Politicamente, encontrou expressão nos governos populistas de Getúlio Vargas (1951-1954) e Juscelino Kubitschek (1956-1961) (MANTEGA, G. A Economia Política Brasileira. São Paulo/Petrópolis: Polis/Nozes, 1985, Capítulo 1). 
intelectual. Para Roberto Schwarz, a partir das décadas de 1940 e 1950, estabelece-se um vínculo estreito entre o projeto de formação nacional e o nacionaldesenvolvimentismo:

(...) a sociedade brasileira lutava para se completar no plano econômico e social. o impulso formativo recebia o influxo materialista da industrialização em curso e tinha como aspiração e eventual ponto de chegada o país industrial, que se integra socialmente através da reforma agrária, superando o atraso material e a posição subalterna no concerto das nações. ${ }^{31}$

Por vezes, o nacional-desenvolvimentismo - ao colocar em questão a idéia do Brasil enquanto "país novo", substituindo-a, a partir dos anos 1950, pela "consciência do subdesenvolvimento"32 - imprimia ao projeto da formação "uma dimensão dramática, de ruptura, que (...) se avizinhava da ruptura de classes e da revolução socialista" ${ }^{33}$.

Mas não foi sempre que essa dimensão transformadora radical do ideário nacional-desenvolvimentista se fez presente: veja-se o exemplo significativo do Partido Comunista $(P C B)$ - cuja política era referência para muitos artistas e intelectuais de esquerda, como Artigas $^{34}$. Como mostra o próprio Schwarz, o PCB sustentava,

31 SCHWARZ, R. "Os sete fôlegos de um livro". In: Seqüências brasileiras: ensaios. São Paulo, Cia das Letras, 1999, p. 56. Grifos nossos.

32 Abordando o "problema das relações entre subdesenvolvimento e cultura", tal como colocado por Mário Vieira de Mello, Antonio Candido afirma: "até mais ou menos o decênio de 1930 predominava entre nós a noção de 'país novo', que ainda não pudera realizar-se mas que atribuía a si mesmo grandes possibilidades de progresso futuro. Sem ter havido modificação substancial na distância que nos separa dos países ricos, o que predomina agora é a noção de país subdesenvolvido". Essa mudança de perspectiva de intelectuais e artistas - que, segundo o autor, "evidenciou a realidade dos solos pobres, das técnicas arcaicas, da miséria pasmosa das populações, da sua incultura paralisante" - se alastrando por toda a América Latina a partir dos anos 1950, torna a "idéia de subdesenvolvimento uma força propulsora, que dá novo cunho ao tradicional empenho político dos nossos intelectuais"; é o que o autor chama de "consciência do subdesenvolvimento", em oposição à "consciência ilustrada" típica dos intelectuais do século XIX e primeiros decênios do séc. XX (CANDIDO, A. "Literatura e subdesenvolvimento", 1970. In: A educação pela noite e outros ensaios. São Paulo, Ática, 1989, p. 140-162).

33 SCHWARZ, R. Op. cit., p. 56.

34 A aula inaugural de Artigas na UFRS, em 1959 ("Arquitetura e cultura nacionais") é exemplar, no sentido da ligação entre a ideologia nacional-desenvolvimentista com um projeto de desenvolvimento artístico e cultural para o país. O arquiteto parte da associação entre o sucesso da arquitetura moderna nacional e o esforço dos brasileiros em afirmar a sua "capacidade de criar uma pátria unida e independente, original em suas manifestações culturais e artísticas". Afirma que o Brasil, "nação moderna", teria de caminhar para a industrialização e reforma do regime de propriedade da terra (regime que, diz, "mantém no campo, em condições miseráveis de existência, perto de $60 \%$ da população do país - o mercado interno que tanto valorizamos", e que "nas cidades, faz impossível (...) a aplicação dos princípios urbanísticos e arquitetônicos que tornariam as nossas aglomerações mais humanas"). Reafirma a importância do papel da arquitetura e da engenharia, na "preparação para a industrialização" - considerando o arquiteto como "profissional distinto [do engenheiro]", por ser capaz de "imprimir às formas 
nesses anos, "uma espécie desdentada e parlamentar de marxismo patriótico, um complexo ideológico ao mesmo tempo combativo e de conciliação de classes, facilmente combinável com o populismo nacionalista então dominante" ${ }^{35}$.

Em "Introduzione", essas contradições se mostrarão bem vivas. O projeto de formação plena da nação que Motta expõe nesse texto, ao invés de caminhar para a consciência do subdesenvo/vimento e para uma radicalização do projeto formativo, apela para a burguesia - não para a burguesia em geral, mas sim para o setor urbano-industrial dessa classe, supostamente nacionalista ${ }^{36}$ e progressista - como seu principal agente.

Embora Motta faça alguns reparos críticos pontuais à classe - como quando observa que no "processo de independência nacional", muitas vezes o Estado incentivava as empresas e a iniciativa privada absorvia os lucros ("em um processo nem sempre reversível em benefício da coletividade") - estes surgem sempre no sentido de um apelo bastante ingênuo, que não concebe a "absorção dos lucros", o "privatismo", o "fechado individualismo" da burguesia como inerentes à sua existência enquanto classe.

construtivas as características culturais nacionais", "influenciar a técnica estrutural e canalizar para a indústria a influência de sua atividade criadora". E conclui afirmando que, "no Brasil e na América Latina, o humano é o nacional, a independência econômica, a luta contra o subdesenvolvimento, muito atraso e muita miséria. O Brasil, na América, é um país vasto e de maiores recursos, onde a posição das forças progressistas pode exprimir-se através de formas mais concretas, mais objetivas. Quero ver, nas nossas manifestações culturais, a expressão destas forças" (ARTIGAS, V. "Arquitetura e cultura nacionais", 1959. In: Caminhos da arquitetura. São Paulo, Fupam/ Cosacnaify, 1999, p. 113-121).

35 Schwarz faz duras críticas ao PCB e à posição das esquerdas naqueles anos que antecedem o Golpe Militar. Para o autor, "antes de 64, o socialismo que se difundia no Brasil era forte em anti-imperialismo e fraco na propaganda e organização da luta de classes. A razão esteve em parte ao menos na estratégia do Partido Comunista, que pregava aliança com a burguesia nacional. Formou-se em conseqüência uma espécie desdentada e parlamentar de marxismo patriótico, um complexo ideológico ao mesmo tempo combativo e de conciliação de classes, facilmente combinável com o populismo nacionalista então dominante, cuja ideologia original, o trabalhismo, ia cedendo terreno (...) Muito mais anti-imperialista que anti-capitalista, O PC distinguia no interior das classes dominantes um setor agrário, retrógrado e próamericano, e um setor industrial, nacional e progressista, ao qual se aliava contra o primeiro. Ora, esta posição existia, mas sem a profundidade que Ihe atribuíam, e nunca pesaria mais do que a oposição entre as classes proprietárias, em bloco, e o perigo do comunismo. O PC entretanto transformou em vasto movimento ideológico e teórico as suas alianças, e acreditou nelas, enquanto a burguesia não acreditava nele. Em conseqüência chegou despreparado à beira da guerra civil. Este engano esteve no centro da vida cultural brasileiro de 1950 para cá" (SCHWARZ, R. "Cultura e política, 1964-1969", 1970. In:

O pai de família e outros estudos. Rio de Janeiro, Paz e Terra, 1978, p. 63-65).

36 Mantega demonstra bem como esse nacionalismo era bastante "flexível", já que a "afirmação nacional" ou o anti-imperialismo propugnado pelos desenvolvimentistas nunca significou a recusa à relação com o capital internacional, contanto que esse contribuísse para a industrialização (MANTEGA, G. A Economia Política Brasileira. São Paulo/Petrópolis: Polis/Nozes, 1985, Capítulo 1). 
Em um certo senso, é o Estado mesmo que forma a burguesia; burguesia esta, que deve enfrentar responsavelmente os grandes problemas do planejamento nacional. Para que possa realizar esse programa não deve, entre outras coisas, esquecer-se de que em São Paulo (3.231.462 habitantes) e no Rio de Janeiro (2.984.988 habitantes) a ausência de um plano regulador é a causa do mal-estar social. O caráter de fechado individualismo que ameaça denegrir o papel civilizatório da burguesia brasileira, requer, sobretudo, uma revisão histórica. Quando Euclides da Cunha dizia que no Império o único equilíbrio possível era o "equilíbrio dinâmico entre as aspirações populares e as tradições dinásticas", estava atribuindo às tradições dinásticas um caráter simbólico no âmbito da unidade nacional. Hoje essa missão é, na maior parte, da burguesia. ${ }^{37}$

A ruptura de classe e a aproximação com o socialismo não acontecem. Ao propor que o seu método da "revisão histórica" seja aplicado à própria burguesia, cujo "papel civilizatório" estaria ameaçado, Motta espera que a burguesia retome uma postura progressista, segundo o esquema do PCB. A divisão social desigual do trabalho e a luta de classes inexistem em sua concepção; para ele, a sociedade parece estar baseada em diferentes grupos, cada um destinado a colaborar, com tarefas distintas, para a construção da nação:

Contudo, se compete à burguesia grande parte desta atribuição de planificação econômica, é, em última análise, tarefa dos intelectuais defender a fisionomia política do país, as suas exigências culturais, necessárias à atividade criativa, expressão do "equilíbrio dinâmico" que emana das aspirações populares. ${ }^{38}$

Aos arquitetos, é delegada uma função especial, pois, além de intelectuais, estes seriam artífices da nação:

Se coloca assim, na fase atual da vida brasileira, a figura do arquiteto como intelectual e como principal artífice da nação. Cabe ao arquiteto contribuir do melhor modo na orientação dessa burguesia em sua fase de planejamento. Ao enfrentar esses problemas, deve estar atento à continuidade e à harmonia da produção, naquilo que concerne à organização do espaço, ao adequado emprego dos materiais, e à individualidade expressiva de sua obra como fato de cultura. ${ }^{39}$

37 MOTTA, F. "Introdução ao Brasil", 1960. Trad. J. B. Costa. In: COSTA, J. B. Ver não é só ver: dois estudos a partir de Flávio Motta. São Paulo, FAUUSP (Dissertação de Mestrado), 2010, p. 206. Na versão original: "In un certo senso è lo stato stesso che forma la borghesia; borghesia, questa, che deve affrontare responsabilmente i grandi problemi di pianificazione nazionale. Perchè possa realizzare questo programma non deve, tra le altre cose, dimenticare che a San Paolo (3.231.462 ab.) e a Rio de Janeiro (2.984.988 ab.) la mancanza di un piano regolatore è causa di malessere sociale. Il carattere di chiuso individualismo che minaccia di denigrare il ruolo civilizzatore della borghesia brasiliana, richiedè, anzitutto, una revisione storica. Quando euclides da Cunha diceva che nell'Impero I'unico equilibrio possibile era 'l'equilibrio dinamico tra le aspirazioni popolari e le tradizioni dinastiche', stava attribuendo alle tradizioni dinasttiche un carattere simbolico nell'ambito dell'unità nazionale. Oggi questa missione è, in maggioranza, della borghesia" (MOTTA, F. "Introduzione al Brasile", 1960. In: Revista Zodiac, no. 6, 1960, p. 66-67).

38 Ibid. Na versão original: "Però, se tocca alla borgheisa gran parte di questo compito di pianificazione economica, è in ultima analisi compito dell'intellettuale difendere la fisionomia politica del Paese, le sue esigenze culturali, necessarie all'atività creatrice, espressione de quell"equilibrio dinamico' che emana dalle aspirazioni popolari". (MOTTA, F. "Introduzione al Brasile", 1960. In: Revista Zodiac, no. 6, 1960, p. 66-67)

39 Ibid., p. 206-207. 
Entre tais grupos, Motta não observa conflito ou exclusão, mas complementaridade de papéis: a burguesia industrial controlando a economia do país, o povo expressando suas aspirações através da "atividade criativa" e, por fim, os intelectuais e os arquitetos, um grupo imparcial de mediadores ou conciliadores que ao mesmo tempo defende as exigências populares e colabora com a burguesia.

À posição ingênua que acredita em um "papel civilizatório" da burguesia, corresponde a visão idealizada do povo. Embora na argumentação de Motta as "aspirações populares" ocupem um papel central na constituição da formação plena da nação, verifica-se que a noção (na verdade, o desejo) de uma "unidade civilizadora" sobrepõe-se à investigação concreta sobre a sociedade brasileira. $\mathrm{O}$ povo não adquire uma forma definida e nem um lugar claro e ativo no processo histórico e político ${ }^{40}$, o que acaba inclusive por prejudicar a leitura das contribuições populares no âmbito da própria cultura.

Percebe-se isso, por exemplo, no entendimento do autor de que, no processo de "caracterização cultural" do país, o que deveria ser salvaguardado seria uma "uma organização isenta de preconceitos raciais (...) uma civilização que tem tanto da européia, como da indígena, asiática, africana, norte-americana e católica"41 - uma visão de harmonia e cordialidade, que dificilmente seria corroborada em um estudo histórico mais rigoroso, e cujo avesso já vinha sendo exposto desde Raízes do Brasil, de Sérgio Buarque de Holanda (1902-1982). Também a interpretação dada ao movimento antropofágico - de que a facilidade de adaptação dos indígenas permitiria a co-existência com a "civilização" - mostra que Motta, embora admirador do modernismo, abandona o sentido violento e dialético da "deglutição" enunciada.

Parece-nos que Motta começa a se afastar de suas próprias intuições iniciais (quando redescobria o trabalho artesanal imigrante, por exemplo), ao ligar o popular, o primitivo e o trabalho não a um potencial negativo - potencial que, a

40 Schwarz, ainda discutindo a influência do "marxismo patriótico" do PCB no pensamento das esquerdas, coloca: "O aliado principal do imperialismo, e portanto o inimigo principal da esquerda, seriam os aspectos arcaicos da sociedade brasileira, basicamente o latifúndio, contra o qual deveria erguer-se o povo, composto por todos aqueles interessados no progresso do país. Resultou no plano econômico-político uma problemática explosiva mas burguesa de modernização e democratização; mais precisamente, tratava-se da ampliação do mercado interno através da reforma agrária, nos quadros de uma política externa independente. No plano ideológico resultava uma noção de "povo" apologética e sentimentalizável, que abraçava indistintamente as massas trabalhadoras, o lumpesinato, a intelligentsia, os magnatas nacionais e o exército". (SCHWARZ, R. "Cultura e política, 1964-1969", 1970. In: O pai de família e outros estudos. Rio de Janeiro, Paz e Terra, 1978, p. 65).

41 MOTTA, F. "Introdução ao Brasil", 1960. Trad. J. B. Costa. In: COSTA, J. B. Ver não é só ver: dois estudos a partir de Flávio Motta. São Paulo, FAUUSP (Dissertação de Mestrado), 2010, p. 202. 
nosso ver, implicaria necessariamente na denúncia ou contraposição à burguesia e ao seu conceito de "civilização" ${ }^{42}$ - mas a um objetivo de "integração" entre "impulsos contraditórios".

Em relação ao papel conferido aos intelectuais, talvez seja possível dizer que a concepção de Motta aproxima-se mais da descrição que Antonio Candido faz acerca da "consciência ilustrada" dos educadores liberais dos anos 1930, do que de das formulações mais radicais como as da "consciência do subdesenvolvimento" - já em formação a partir da década de $1950^{43}$, e que viriam a se fortalecer ao longo dos anos 1960. Em 1930, coloca Candido, a repercussão do movimento revolucionário no plano da cultura permite que as elites conheçam um "grande incremento de oportunidades para ampliar e aprofundar a sua experiência cultural, inclusive com a aquisição de um corte progressista por alguns de seus setores" - note-se que esse progressismo refere-se a uma "posição crítica em face dos regimes autoritários e da mentalidade conservadora", mas não necessariamente contrária à burguesia e exploração capitalista. Devido à "privação extrema" do país, estas elites - que assumem a função de "delegados da coletividade" - mantêm uma posição socialmente privilegiada ao mesmo tempo em que, culturalmente, servem como veículo para manifestar as necessidades de expressão das camadas populares ${ }^{44}$.

\subsection{A arquitetura moderna brasileira}

Dentro dessa perspectiva geral que agora é posta com maior clareza, apura-se também a análise histórico-crítica de Motta acerca da arquitetura moderna brasileira. As preocupações antes apenas esboçadas - que apareciam pontualmente, como em Contribuição..., quando Motta alertava que seria necessário para a arquitetura moderna resistir e formar tradição, se alimentando dos "dados da técnica moderna" oferecidos pela industrialização ${ }^{45}$ - ganham uma nova elabo-

42 Lina, por exemplo, identifica claramente a civilização burguesa com um determinado tipo de cultura, que certamente não é aquele da "procura técnico-primitiva duma cultura original", mas sim a dos gadgets e do consumo - e afirma, já colocando uma discussão que irá se desenvolver nos anos seguintes: "Aquilo que geralmente se denomina 'povo' é a única classe não inibida por esquemas e conceitos 'culturais', a única talvez que conserva o hábito de explicações naturais do homem estético" (BARDI, L. e GONÇALVES, M. "Bahia no Ibirapuera", 1959. In: Lina bo Bardi. São Paulo, Instituto Lina bo e P.M. Bardi, 1996, p. 134).

43 Cf. nota 32, neste capítulo.

44 CANDIDO, A. "A Revolução de 30 e a cultura", 1980. In: Novos estudos CEBRAP, v.2, 4, abr. 1984, p. 34.

45 MOTTA, F. Contribuição ao estudo do art nouveau no Brasil. Tese (cátedra). São Paulo, FAUUSP, 1957, p. 54. Grifos nossos. 
ração. Referindo-se ao nascimento da arquitetura moderna brasileira, após citar as contribuições de Lucio Costa e Le Corbusier, diz Motta:

\begin{abstract}
Todas as características dessa nova arquitetura, num progressivo e ininterrupto desenvolvimento, vinham ao encontro da realidade social e econômica. Viviam, contudo, da vitalidade emocional de uma rebelião, através da qual fluía a fantasia generosa de Oscar Niemeyer, produzindo sobressaltos na trama diabólica do calculista de concreto armado Joaquim Cardoso. Era o estímulo, como se a visão poética fosse o momento primeiro das coisas. Era, enfim, o estimulo da "Corte", suscetível às rápidas deformações por causa do provincianismo. Sim, o provincianismo se tornava o maior parasita; o provincianismo que o poeta Fernando Pessoa classificou como mania do grande, mania do moderno e incapacidade para a ironia ${ }^{46}$. $O$ poético se particularizava, mas não se individualizava. Multiplicava os elementos, mas não criava formas. ${ }^{47}$
\end{abstract}

O valor da fantasia, da visão poética - cujo maior representante é sem dúvida Niemeyer - é reconhecido pelo autor, mas ao mesmo tempo posto em cheque. Num momento em que "os determinantes do Movimento Moderno, dia após dia subjugado à 'corrida imobiliária' e aos fenômenos paralelos, são objeto de contínuas discussões e de reivindicações de âmbito coletivo"48 - ou seja, num momento em que a arquitetura moderna passa a ser incorporada pelo mercado, e em que os arquitetos parecem estar sendo transformados em "co-autores inconscientes das realizações do mais grosseiro 'privatismo'" 49 - Motta preocupa-se com a fragilidade de uma produção arquitetônica fundada no estímulo.

46 A crítica de Motta à mania do moderno já vinha sendo feita por outros autores, desde o inicio da década de 1950. Lina em 1951 alerta para a necessidade de combate ao que identifica como um nascente "vezo modernístico" na arquitetura brasileira (Cf. nota 123, Capítulo 3), "generalização perigosa (...), desmoralização do espírito de arquitetura moderna, que é um espírito de intransigência e do amor para o homem, que nada tem que ver com as formas exteriores e as acrobacias formalísticas" (BARDI, L. "Bela criança". In: Revista Habitat no. 2, jan/mar 1951, p. 3). Artigas e Luis Saia também se posicionam acerca da questão, como veremos logo adiante.

47 MOTTA, F. "Introdução ao Brasil", 1960. Trad. J. B. Costa. In: COSTA, J. B. Ver não é só ver: dois estudos a partir de Flávio Motta. São Paulo, FAUUSP (Dissertação de Mestrado), 2010, p. 206. Na versão original: "Tutte le caratteristiche di questa nuova architettura, per un progressivo e ininterrotto sviluppo, attendevano un riscontro dalla realtà sociale e economica. Vivevano però della vitalità emotiva d'una ribellione, attraverso la quale fluiva la fantasia generosa di Oscar Niemeyer, producendo soprassalti nelle macchinazioni diaboliche del calcolatore de cemento armato Joaquim Cardoso. Era lo stimolo, come se la visione poetica fosse il momento primo delle cose. Era, infine, lo stimolo della 'Corte', suscettbile di rapide deformazioni a causa del provincialismo. Sì, el provincialismo che el poeta Fernando Pessoa classificò come mania del grande, mania del moderno e incapacità per l'ironia. Il poetico si particolarizzava ma non si individualizzava; moltiplicava gli elementi, ma non creava forme". (MOTTA, F. "Introduzione al Brasile", 1960. In: Revista Zodiac, no. 6, 1960, p. 66).

48 MOTTA, F. "Introdução ao Brasil", 1960. Trad. J. B. Costa. In: COSTA, J. B. Ver não é só ver: dois estudos a partir de Flávio Motta. São Paulo, FAUUSP (Dissertação de Mestrado), 2010, p. 206.

49 Ibid., p. 207. 
A crítica de Motta não parece se dirigir a Niemeyer exclusivamente; o seu alerta é em relação aos riscos e conseqüências de defesa da "expressão individual" ou da "genialidade" do artista sem inseri-las ou confrontá-las com a realidade (social, econômica, cultural, histórica) do país. O que Motta parece estar questionando é até onde poderia chegar, que frutos poderiam nascer da fantasia de Niemeyer ou de qualquer outro artista, frente à mesquinhez da burguesia e à especulação imobiliária que se apropriava do repertório moderno.

Essa "deformação" da "visão poética" moderna, do momento inicial de fantasia e rebeldia, se dá, a seu ver, de duas formas: por um lado, pela "multiplicação de elementos", reprodução incansável de fórmulas, formas e mesmo palavras modernas, com total ausência de invenção ou criação original ${ }^{50}$. Por outro lado, pela particularização (e não "individualização") do poético: estando a invenção impedida de se de se tradicionalizar ${ }^{51}$ e de se tornar "social" (a arquitetura moderna como "ilha" no mar de barracos...), estaria também impossibilitada de ser expressão plena do indivíduo, de ser obra de arte verdadeira, no sentido utiliza-

500 arquiteto Luis Saia já observava bem essa situação, ao avaliar, em 1954, que um "academismo moderno" estaria a surgir, no Brasil. Diz ele: "Com efeito, as cartas do atual baralhão são poucas e fáceis, eficientes e rendosas: meia dúzia de soluções formais e algumas palavras de poder mágico: Brise-soleil, Colunas em V, Pilotis, Amebas, panos contínuos de vidro, Moderno, Funcional, etc. O prestigio dessas formas e dessas palavras e o seu abuso sonegam a consideração justa dos problemas". E completa, estendendo suas preocupações em direção ao urbanismo: "A palavra funcional perde seu verdadeiro sentido (...) É fácil demonstrar como um edifício individualmente funcional - com uma perfeita organização interna dos espaços, esquema construtivo adequado e lógico e aspecto plástico aceitável - pode, entretanto, apresentar gritante aberração do ponto de vista do seu uso, pela inoportunidade e inadequação do local" (SAIA, L. "A fase heróica da arquitetura contemporânea brasileira já foi esgotada há alguns anos", 1954. In: Arte em Revista, n. 4, ago 1980, p. 51-52).

51 Usamos aqui a noção de invenção tal como colocada por Argan, em "Tradição e materiais antigos na arquitetura". Nesse texto de 1959, publicado em Habitat, o crítico italiano defende teoricamente a interdependência entre "invenção" e "tradição", constituindo-se, assim, numa referência fundamental para entender as discussões de Lina e Motta e como elas se relacionam aos debates que ocorriam internacionalmente. Diz Argan: "Como não existe, a rigor, uma arte moderna, assim também não existe uma arte tradicional ou do passado inteiramente diferente dos fenômenos contemporâneos; ao contrário, a experiência prova que a obra de um artista é tanto mais original (...) quanto mais vasto é o seu trato, no espaço e no tempo, da série fenomênica da arte do passado. Mas é preciso acrescentar (...) que a obra de arte só existe, isto é, inscreve-se na série histórica dos fenômenos artísticos, quando se caracteriza por qualquer coisa de novo, por uma 'invenção' (...) O caráter de invenção foi claramente definido por Bergson, Le Roy e Merleau-Ponty: a invenção não é outra coisa que uma sorte de excitação enquanto se está no limiar do presente, onde tudo está por decidir, onde se deve escolher uma orientação ou uma direção que dêem significado e valor à experiência passada (que é então o conteúdo da consciência, ou a própria consciência), isto é, ao tempo 'vivido'. Com isto se opera a superação do passado, que se faz presente. A invenção não é, pois, outra coisa que uma interpretação da experiência ou do passado; e não pode ser considerada senão como crítica do passado. A arte moderna se reconhece como tal pela interpretação que dá ao passado" (ARGAN, G. C. Tradição e materiais antigos na arquitetura". In: Revista Habitat, no. 58, 1960, p. 3). 
do por Mário de Andrade ${ }^{52}$. Com a particularização da arquitetura, a assinatura e a "originalidade" do autor (no caso, do arquiteto) passam a ser mais importantes do que a própria obra; as descobertas e conquistas - técnicas, formais, sociais - da arquitetura moderna são assim reduzidas a mesquinhos interesses particulares, ou melhor, privados ${ }^{53}$.

Motta irá defender uma concepção de "moderno" que ultrapasse o momento da rebelião niemeyeriana, insistindo na necessidade de tradicionalização da arquitetura moderna nacional - posição já manifesta anteriormente, mas que agora ganha novos contornos, na medida em que um sistema arquitetônico parece estar concretamente se constituindo no Brasil. Isso poderia ser notado, por exemplo, pela valorização da profissão do arquiteto e da organização da classe, com a consolidação do Instituto de Arquitetos (IAB) e pela fundação, no segundo pós-guerra, das escolas de arquitetura - onde, segundo Motta, "o espírito crítico e de equipe adquiriu um novo significado":

(...) a formação universitária do arquiteto representa um enriquecimento de quadros, cujo significado foi expresso no último encontro realizado em São Paulo entre arquitetos, professores e estudantes de arquitetura de todos os estados do Brasil. Aqui foram definidas as atribuições e reivindicações do arquiteto, seja buscando um modo de frear a especulação imobiliária, seja buscando uma maior diferenciação do engenheiro civil (...). Ainda hoje, no Brasil, foram profissionais sem formação humanística, os co-autores inconscientes das realizações do mais grosseiro "privatismo". Acrescenta-se que a contribuição dos novos arquitetos, formados em escolas de criação recente, já se faz sentir. Não obstante exista uma longa tradição no ensino de arquitetura, é hoje possível no Brasil instituir tal ensinamento com relativa organicidade, uma vez que as maiores preocupações são voltadas ao caráter formativo; aos imperativos metodológicos; ao sentido decrescente dos fatores instrumentais e informativos; ao estimulo das manifestações espontâneas em escala crescente de integração na consciência civilizadora. ${ }^{54}$

52 Para Mário de Andrade, a "arte verdadeira" seria necessariamente, ao mesmo tempo, expressão do indivíduo e das exigências da matéria, ou, em outras palavras, expressão dos "caracteres e exigências humanos, individuais e sociais, do artefazer" (ANDRADE, M. "Curso de filosofia e história da arte", 1938. In: Depoimentos 2. São Paulo, CEB/GFAU, 1966, p. 30).

53 Artigas tem muita clareza acerca dessa operação de deformação da arquitetura moderna efetuada pelo mercado (ou pela burguesia, para sermos mais precisos). Em 1952, o arquiteto avalia: "a Arquitetura Moderna brasileira progride no sentido de servir de cartaz de propaganda para tudo quanto é malandragem comercialesca do tipo vendas em condomínio e hotéis em praias desertas" (ARTIGAS, V. "Os caminhos da arquitetura moderna", 1952. In: Caminhos da arquitetura. São Paulo, Fupam/ Cosacnaify, 1999, p. 42). Em 1956, reitera a denúncia: "o surto imobiliário destes últimos anos assimilou, ainda que atabalhoadamente, algumas soluções de nossa arquitetura, ajudou a completar a derrota do ecletismo antes existente e enriqueceu os construtores" (Idem. "Rumos para o ensino da arquitetura", 1956. In: Op. cit., p. 46).

54 MOTTA, F. "Introdução ao Brasil", 1960. Trad. J. B. Costa. In: COSTA, J. B. Ver não é só ver: dois estudos a partir de Flávio Motta. São Paulo, FAUUSP (Dissertação de Mestrado), 2010, p. 207. 
Também "a procura de uma maior eficácia nas conquistas técnicas", por parte de certos arquitetos, poderia ser uma evidência da incipiente formação de uma tradição ${ }^{55}$ : os exemplos citados por Motta são o pavilhão de Sérgio Bernardes (19192002) ${ }^{56}$, os detalhes construtivos de Reidy e Jorge Moreira (1904-1992), a "sintaxe disciplinada" de Rino Levi e as "numerosas obras de Niemeyer em Brasília"57.

Mas, dentre vários nomes importantes, é no de Vilanova Artigas que Motta irá se deter. A obra de Artigas parece ser uma espécie de exemplo de como a arquitetura moderna brasileira repensava, naquele momento, os seus próprios valores - sem negar os avanços já conquistados.

(...) se quisermos citar ainda um exemplo entre os nomes menos conhecidos da crítica estrangeira, encontramos aquele do arquiteto Vilanova Artigas que realiza em São Paulo uma intensa atividade doutrinária, seguindo o exemplo de Lucio Costa no que diz respeito às exigências de uma posição teórica. ${ }^{58}$

55 Aqui, novamente podemos nos referir a Mário de Andrade, a Lina e à Habitat, e às discussões acerca da técnica feitas nos Capítulos 1 e 3. Desenvolvendo esta discussão, em 1960, Lina coloca que a contemporaneidade exigiria "um novo humanismo", oposto ao "velho intelectualismo pernóstico-literário" e ao "limitado positivismo científico", e que tenderia à "fusão, numa visão técnica do mundo, dos problemas culturais": "hoje (...) a emoção da ciência traduzida em técnica pelo homem é a mesma comunicada por uma obra de arte. Equilíbrio, estrutura, rigor, aquele mundo que o homem não conhece, que a arte sugere (...). Assim a arte volta a identificar-se com a técnica como nos tempos primitivos (...) os homens são arrastados pelo mecanismo por eles mesmos criado, e com um fator desconhecido às civilizações passadas, a capacidade crítica" (BARDI, L. "Técnica e arte", 1960. In: RUBINO, Silvana [org.]. Lina por escrito: textos escolhidos de Lina bo Bardi. São Paulo, Cosacnaify, 2009, p. 112).

56 Pavilhão construído para a Exposição Internacional da Indústria e do Comércio, no Rio de Janeiro, entre 1957 e 1960. Também conhecido como Pavilhão de São Cristóvão, este edifício combina uma ousada pesquisa técnica e estrutural (como a cobertura em forma de parabolóide-hiperbólico) com a exploração de materiais "comuns" e relativamente baratos (como os tijolos de barro, que são dispostos de maneira a formar grandes paredes vazadas, numa clara referência aos elementos vazados da arquitetura vernacular).

57 Não deixa de ser curiosa essa inclusão de Niemeyer dentre os arquitetos preocupados com "uma maior eficácia nas conquistas técnicas", já que apenas alguns parágrafos antes Motta havia identificado a sua obra com um estimulo sujeito à deformações. O que nos parece é que, depois do "Depoimento" de 1958, Niemeyer recebe um "voto de confiança" por parte daqueles que começavam a questionar a sua posição e sua obra - não apenas Motta, mas também Artigas e Mário Pedrosa, dentre muitos outros (Lina, para variar, está na contra-corrente e faz críticas contundentes ao "Depoimento", em seu artigo "arquitetura ou Arquitetura", também de 1958). No "Depoimento", o arquiteto carioca faz uma autocrítica de sua produção até 1956, identificando nela reflexos de sua descrença em relação à arquitetura e "uma tendência excessiva para a originalidade" - ambos problemas ligados à ausência de "lastro social" da arquitetura e ao fato contraditório da atuação dos arquitetos estar relegada apenas a "atender os caprichos das classes abastadas". Propõe, a partir dessa autocrítica, a adoção de "uma série de providências e medidas disciplinadoras", como a "redução de trabalhos no escritório" e "recusa sistemática" de projetos que visassem apenas a "interesses comerciais", além do estabelecimento de normas visando à "simplificação da forma plástica e ao seu equilíbrio com os problemas funcionais e construtivos" (NIEMEYER, O. "Depoimento", 1958. In: Revista Zodiac, no. 6, 1960, p. 131-135).

58 MOTTA, F. "Introdução ao Brasil", 1960. Trad. J. B. Costa. In: COSTA, J. B. Ver não é só ver: dois estu- 
Com a sua "intensa atividade doutrinária" - que, como sabemos, abarcava a militância no Partido Comunista, a militância junto à categoria profissional, a atuação como professor na FAUUSP, além do trabalho de projeto propriamente dito -, Artigas é visto por Motta como um arquiteto capaz de criar forma enquanto reflete sobre as condições sociais e econômicas do país; um arquiteto cuja obra considera e expressa o desenvolvimento cultural brasileiro; alguém que enfrenta e denuncia as precárias condições da construção civil no Brasil, seja na pesquisa de processos construtivos, seja no canteiro de obras.

\begin{abstract}
Influenciado inicialmente por Frank Loyd Wright, Artigas não deixou de observar o fenômeno "liberty" no Brasil, e teve a rápida intuição de que as premissas modernas desse movimento foram prejudicadas pelas condições sociais e econômicas do país. As suas realizações revelaram o esforço de alcançar novas formas através de processos construtivos independentes da instabilidade da indústria da construção nascente. As suas casas de moradia, projetadas para intelectuais e profissionais liberais, são caracterizadas pela economia de recursos da construção, onde, às vezes, o arquiteto se mistura intimamente à atividade do mestre-de-obra e do operário. ${ }^{59}$
\end{abstract}

Há, nas colocações de Motta sobre Artigas, um claro diálogo com o artigo de Bruno Alfieri publicado no Rapporto, "João Vilanova Artigas: ricerca brutalista". O editor italiano também identifica um caráter de doutrina na obra de Artigas, ao destacar as convicções políticas e sociais do arquiteto e definir a sua personalidade como "complexa (...) fortemente reativa ao ambiente que o circunda" 60 .

Para Alfieri, a arquitetura de Artigas é "dramaticamente contraditória", de uma "aberta e viva problematicidade (...) sempre impregnada de cultura e nunca privada de coragem": esse caráter problematizador e contestatório estaria presente

dos a partir de Flávio Motta. São Paulo, FAUUSP (Dissertação de Mestrado), 2010, p. 207. Grifos nossos. Na versão original: "(...) se vogliamo citare ancora un esempio tra i nomi meno conosciuti dalla crtitica straniera, incontriamo quello dell'architetto Vilanova Artigas che realizza in São Paulo un'intensa attività dottrinaria, seguendo l'esempio di Lucio Costa per quanto riguarda le esigenze di una posizione teorica" (MOTTA, F. "Introduzione al Brasile", 1960. In: Revista Zodiac, no. 6, 1960, p. 67).

59 MOTTA, F. "Introdução ao Brasil", 1960. Trad. J. B. Costa. In: COSTA, J. B. Ver não é só ver: dois estudos a partir de Flávio Motta. São Paulo, FAUUSP (Dissertação de Mestrado), 2010, p. 207-208. Na versão original: "Sia la sua opera che il contenuto irreverente della sua speculazione, assumono, a volte, un carattere addirittura brutale. Influenzato inizialmente da Frank Loyd Wright, Artigas non tralasciò di osservare il fenomeno 'liberty'nel Brasile ed ebbe la rapida intuizione che le premesse moderne do questo movimento furono pregiudicate delle condizione sociali e economiche del Paese. Le sue realizzazioni rivelarono lo sforzo di giungere a nuove forme attraverso processi costrutivi indipendenti dell'instabilità della industria construtiva nascente. Le sue case d'abitazione, progettate per intelletuali e liberi profesionisti, sono caratterizzate dall'economia dei mezzi di costruzione, dove, a volte, l'architetto si mescola intimamente all'atività del capomastro e dell'operario" (MOTTA, F. "Introduzione al Brasile", 1960. In: Revista Zodiac, no. 6, 1960, p. 67).

60 ALFIERI, B. "João Vilanova Artigas: ricerca brutalista". In: Revista Zodiac, no 6, 1960, p. 97. 
desde as primeiras obras, de influência wrightiana ("um ato polêmico, no ambiente brasileiro, atraído pelo racionalismo corbusiano"); manifestar-se-ia nas análises do arquiteto sobre o ambiente social brasileiro e em sua aproximação com o liberty ${ }^{61}$; e, no presente, se manifestaria pela "pesquisa brutalista", "rica em fermentos políticos, éticos e estéticos" - pesquisa que estaria, inclusive, na contra-corrente do ambiente "otimista, celebrativo e simbólico" da inauguração de Brasília ${ }^{62}$.

Motta também adota o termo brutalismo para descrever a obra recente de Artigas, embora com ressalvas:

Hoje as suas realizações vão amadurecendo em direção a um aparente "brutalismo". Deve-se notar que muitas vezes no "brutalismo", a agressividade é denunciada mas não se expressa como maturidade afetiva e emocional, ou seja, como fator de integração social. Aquilo que esse arquiteto brasileiro procura é a expressão da energia que penetra na matéria com o vigor e a obstinação de quem não impõe limite ao espaço, mas o escava procurando o vazio para o homem. ${ }^{63}$

Motta diz que há, na obra de Artigas, uma denúncia da agressividade - e por isso fala em "aparente brutalismo": o "brutal" na verdade estaria fora da obra de Artigas (na especulação imobiliária, no desordenado crescimento urbano, na falta de planejamento...). Para ele, o essencial na obra do arquiteto - aquilo que Ihe conferiria a capacidade de "integração social" - parece ser outra coisa: a sua profunda preocupação humanística, a sua capacidade de criar forma en-

61 O fato de tanto Motta quanto Alfieri destacarem a influência wrightiana de Artigas e o seu conhecimento do art nouveau (ou liberty) demonstra bem como ambos os críticos estavam preocupados em encontrar, nas pesquisas arquitetônicas modernas, a ligação com uma tradição que as re-significasse. Como coloca Argan, "se analisarmos o desenvolvimento da arquitetura e do desenho nas primeiras décadas deste século, constataremos facilmente que os artistas mais originais e o movimento artístico mais vital elaboraram suas proposições formais através de uma crítica do passado. Wright sempre se utilizou de materiais e de processos técnicos, cuja raiz histórica é fácil de encontrar; os holandeses, a começar por Dudok, procuram escrupulosamente combinar a sua arquitetura com um ambiente muito bem caracterizado historicamente; na Bauhaus o estudo crítico dos processos artesanais acompanhava o do projeto. A novidade daquela arquitetura e daquele desenho pode pois ser avaliada pela atitude crítica que os artistas assumem nos confrontos dos processos técnicos, da tipologia, das formas do passado" (ARGAN, G. C. Tradição e materiais antigos na arquitetura". In: Revista Habitat, no. 58, 1960, p. 3).

62 ALFIERI, B. "João Vilanova Artigas: ricerca brutalista". In: Revista Zodiac, no 6, 1960, p. 97.

63 MOTTA, F. "Introdução ao Brasil", 1960. Trad. J. B. Costa. In: COSTA, J. B. Ver não é só ver: dois estudos a partir de Flávio Motta. São Paulo, FAUUSP (Dissertação de Mestrado), 2010, p. 207-208. Na versão original: "Oggi le sue realizzazioni vanno maturando verso un apparente 'brutalismo'. Si deve notare che spesso nel 'brutalismo' l'aggressività è denunciata ma non spressa come maturità affetiva ed emozionale, ossia come fattore di integrazione sociale. Ciò che questo architetto brasiliano ricerca è l'espressione dell'energia che penetra nella materia con il vigore e l'ostinazione di chi non impone limiti allo spazio ma lo scava cercando vuoto per I'uomo". (MOTTA, F. "Introduzione al Brasile", 1960. In: Revista Zodiac, no. 6, 1960, p. 67). 
quanto projeta para o homem, enquanto dá significado humano ao "vazio", ao espaço, à natureza.

Com outras palavras, Alfieri faz uma reflexão próxima à de Motta: para o italiano, o brutalismo de Artigas se caracterizaria, simultaneamente, pela afirmação dos valores da "individualidade" e por uma "sutil e controversa" defesa da socialibilidade ("socialità"), que se daria mediante formas "brutas" e "anti-graciosas". Estas formas configurariam uma arquitetura-manifesto, caracterizada pela ética do uso, e que combinaria a pobreza e nudez dos materiais com ricas possibilidades espaciais (na implantação urbana dos projetos, nos "infinitos pontos de vista" dos interiores) ${ }^{64}$.

Em "Introduzione", no que se refere à arquitetura moderna, Motta mostra ter grandes expectativas em relação à formação de um sistema arquitetônico no Brasil; e associa essa formação à própria construção da nacionalidade - o que fica claro quando aponta o arquiteto, e nenhuma outra classe profissional ou categoria de intelectuais, como "artífice da nação".

Entretanto, como entende Roberto Schwarz (relendo a Formação da literatura brasileira de Antonio (andido), a formação de um sistema no plano cultural não levaria obrigatoriamente ao completamento da sociedade "sob o aspecto da cidadania"65 - ou, usando os termos de Motta, à formação plena da nação. Outras forças e disputas estariam necessariamente envolvidas nesse processo, e são precisamente essas forças e conflitos que a análise de Motta parece ignorar.

A proposta do arquiteto enquanto "artífice da nação", sem a consideração do potencial negativo contido numa cultura pobre (como diz Lina), sem a percepção da luta de classes, acaba assumindo uma orientação totalmente positiva: as possibilidades críticas e de denúncia, a violência contida na arquitetura - que o próprio autor intuitivamente identifica na obra de Artigas, por exemplo - não são apontadas como um caminho a ser explorado, e nem vistas como essenciais (pois a essência estaria na "integração", no equilíbrio e na harmonia, estes sim associados ao verdadeiramente humano).

O projeto estético-político de Mário de Andrade - que ganha consistência nas décadas de 1930 e 1940, quando o modernista formula a noção de "atitude

64 ALFIERI, B. "João Vilanova Artigas: ricerca brutalista". In: Revista Zodiac, no 6, 1960, p. 97.

65 SCHWARZ, R. "Sobre a Formação da Literatura Brasileira". In: Seqüências brasileiras: ensaios. São Paulo, Cia das Letras, 1999, p. 19. 
estética"66 - não é de todo assimilado, já que, à tradicionalização do presente, não se soma o "estado de espírito revoltado e revolucionário" do modernismo, ou uma "maior revolta com a vida como está"67.

Os anos seguintes a 1960 vão exigir de artistas, arquitetos e críticos uma tomada de posição - que as elaborações da década de 1950 sejam de fato colocadas em prática, experimentadas, determinadas. A perspectiva crítica de Motta fica assim enfraquecida; entre a "consciência amena do atraso", e a "consciência do subdesenvolvimento", acaba pendendo para a primeira. Isso não invalida, é claro, as suas contribuições anteriores: o pensamento sobre a técnica e a industrialização no Brasil, a construção crítica sobre a arquitetura brasileira e a historiografia tida como oficial, e, principalmente, a identificação de Artigas como representante de uma nova tendência no movimento moderno brasileiro. Os projetos de Artigas - e, não tão explicitamente, os de Lina, a quem muito nos referimos - são, para nós, o ponto de chegada, o horizonte para o qual a "revisão histórico-crítica" de Motta apontará. E é com eles que poderemos concluir esse trabalho.

66 João Luiz Lafetá, analisando os textos "O artista e o artesão" (1938) e a "Elegia de Abril" (1941), identifica na obra de Mário de Andrade uma "proposta de engajamento constante, em todas às direções: o artista não deve alienar-se nem de si mesmo, nem de seu artesanato, nem da história. A postura ética, de participação, é transportada para dentro da postura estética, e a técnica é vista como um esforço de desalienação, que implica em constante e insatisfeita procura" (LAFETÁ, J. L. "Ética e poética (Mário de Andrade, II)". In: 1930: a crítica e o modernismo. São Paulo, Duas Cidades/ Ed. 34, 2000, p. 213).

67 ANDRADE, M. "O movimento modernista", 1942. In: Aspectos da literatura brasileira. Belo Horizonte, Itatiaia, 2002, p. 280. 


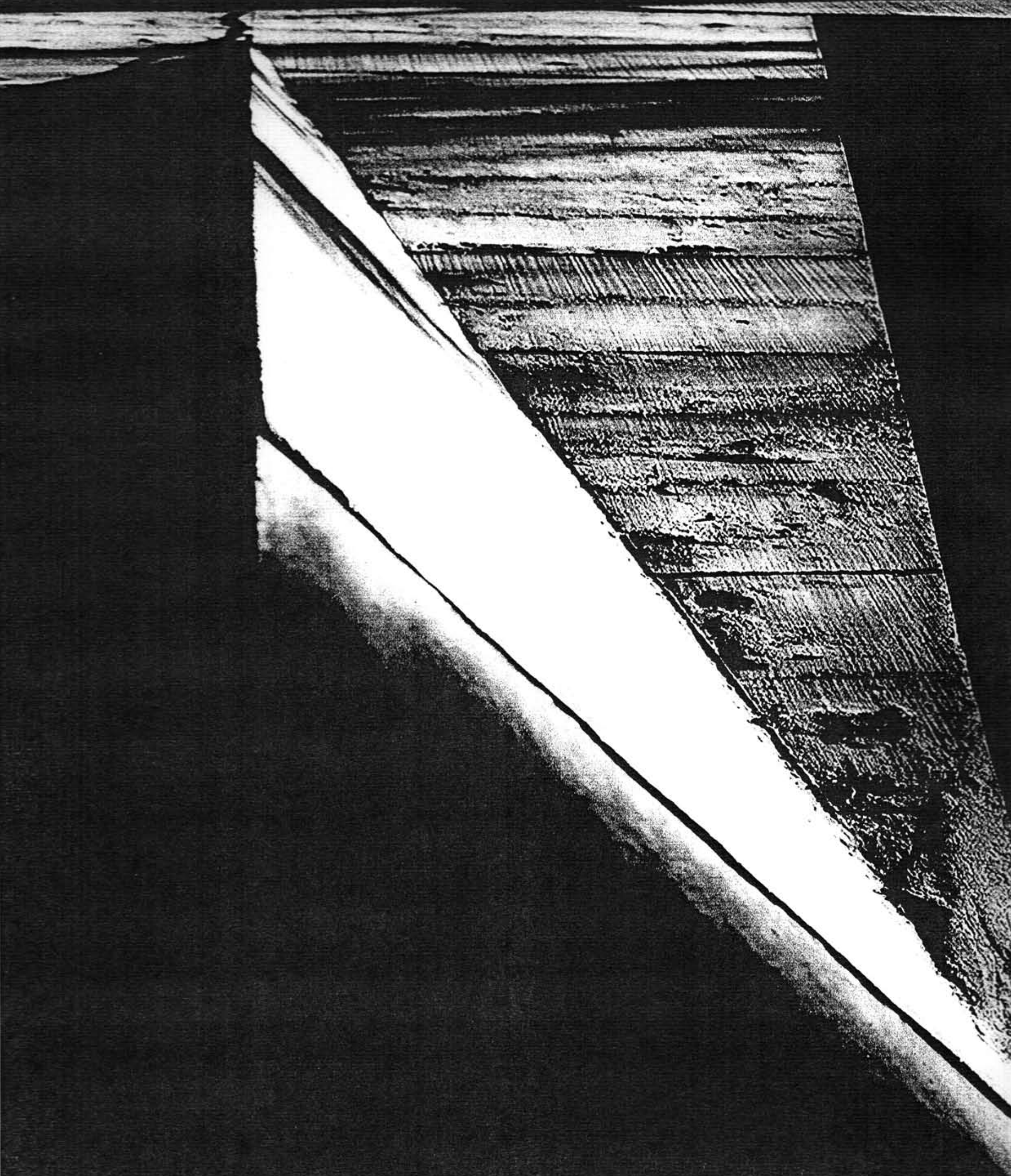


fig 9 [página anterior]

Faculdade de Arquitetura e Urbanismo

(São Paulo), de Vilanova Artigas

foto da autora 


\section{considerações finais}

Ao longo deste estudo, que discutiu como a noção de tradicionalização do presente - chave para a operação de reconstrução da história efetuada por modernistas e modernos brasileiros - se desdobrou na produção de Flávio Motta na década de 1950, pretendemos ter situado histórica e criticamente o seu trabalho, procurando apontar seus limites e potencialidades.

Em textos como "400 anos de pré-história das artes", "São Paulo e o art nouveau", Contribuição ao estudo do art nouveau no Brasil e "Introduzione al Brasile", Motta delineia o seu projeto de reconstrução da história, ou, como diz o próprio autor, a "revisão histórico-crítica" da arte e da arquitetura no Brasil. Em relação à historiografia oficial da arquitetura moderna brasileira, é uma leitura nova, que tem como ponto de partida as insuficiências e limitações do desenvolvimento cultural brasileiro. $\mathrm{O}$ autor valoriza a tradição e a produção coletiva, dando prosseguimento e atualizando, até certo ponto, as preocupações de Mário de Andrade; aponta as ligações entre arte e trabalho, arte e técnica, arte e indústria, localizando-as historicamente e chamando a atenção para novos períodos históricos e regiões do país; problematiza o próprio movimento moderno brasileiro, com a identificação de diferentes tendências e a busca de outros fundamentos para sua produção arquitetônica.

Assim, procurando um lugar e um sentido para o trabalho de Flávio Motta e, mais especificamente, para a "revisão histórico-crítica", acreditamos ter encontrado mais do que um crítico esporádico, um artista esquecido, um velho e admirado professor. O seu trabalho de revisão, especialmente aquele dos anos 1950, coloca-se como um elo importante na história intelectual de São Paulo - trazendo à tona importantes discussões que permitiram-nos delinear as ligações existentes entre o pensamento de Mário de Andrade e a produção arquitetônica paulista das décadas de 1950 e 1960.

Os arquitetos Vilanova Artigas e Lina bo Bardi, ao combinarem intrinsecamente pesquisa estética e projeto político - compromisso que se poderia inclusive ser aproximado da "consciência do subdesenvolvimento", tal como descrita por Can- 
dido1, dialogam, ao longo de toda a década de 1950, com a proposta da "revisão histórico-crítica" formulada por Motta. Artigas, em um revelador depoimento concedido à Aracy Amaral em 1980, explicita bem a existência desse diálogo e de seus desdobramentos:

\begin{abstract}
No início de 50, afirma Artigas, o clima era de crise. Mas felizmente, acrescenta, não endossou as teorias sobre o neocolonial de Demétrio Ribeiro e nem as idéias desse "pessoal sectário (...) Quanto à arquitetura, esse pessoal pensava que o realismo socialista deles estaria solucionado necessariamente com uma arquitetura neocolonial, como o Lúcio Costa tinha inventado. Mas eu sempre estive em desacordo com isso (...) Sei que nunca se soube valorizar o conhecimento do ecletismo, quando ele vem para o Brasil, não surgiu uma palavra sobre o Dubugras, etc. Então surgem esses dois aspectos antagônicos que são: fazer uma arquitetura ligada à História, ou fazer uma arquitetura moderna, mas fora da história, abrindo mão de toda a simbologia que a história da arquitetura trazia para nós, dos gregos até hoje, e que é característica da arquitetura moderna, para servir a uma sociedade nova..."
\end{abstract}

O próprio Niemeyer pode ser questionado nesse ponto, em relação à História, quando fala da inspiração, da "curva doce da mulher amada", do colonial brasileiro, "sou contra o funcionalismo", "acho que os arquitetos devem ser favoráveis à linha curva", etc. "Na verdade", - diz Artigas - "ele não gosta das formas muito estabelecidas, porque ele vacila entre o abstrato e a-histórico e o histórico simbolizado (...) E esse é tema da maior importância para a crítica de arte em geral, porque a idéia de real e histórico é dizer: se a história é a ciência básica, e a única ciência que pode existir, a outra ciência é circunstancial. Por conseguinte, a tecnologia que vem dela, que vai resolver problemas sociais, nega a História, e aqui ficamos... Nessa relação entre a a-história e a História pode-se fazer uma arquitetura em termos plásticos, que não quer saber nada da história (...) Então os mais radicais vêm e dizem que a técnica moderna, a indústria moderna, os novos materiais resolverão todos os problemas, inclusive os sociais. Cria-se aqui a História do trabalho do homem como ciência, tecnologia e produção. E nega a História, que é a história do próprio homem, como se a burguesia estivesse cansada de toda a História, e aparecesse então um caminho novo em que não aparece mais a classe operária. Então, essa vanguarda moderna nega a burguesia, para se por a favor da burguesia sem programa histórico nenhum. Porque sem o homem". ${ }^{2}$

Nos primeiros anos da década de 1960, Lina e Artigas, cada qual à sua maneira, serão capazes de retomar as proposições de Motta e problematizá-las. A consciência do subdesenvolvimento - "dos solos pobres, das técnicas arcaicas, da miséria pasmosa das populações, de sua incultura paralisante" - suscitará, como diz Candido, reformulações políticas. No caso desses arquitetos, essas reformulações ganharão forma também no plano arquitetônico; ambos serão capazes de trabalhar e expressar em suas obras as contradições do processo histórico brasileiro,

1 Cf. nota 32 do Capítulo 3.

2 Depoimento de Vilanova Artigas à Aracy Amaral, em novembro de 1980 (AMARAL, Aracy. Arte para quê? A preocupação social na arte brasileira 1930-1970. São Paulo, Nobel, 1987, p. 298-299. Grifos nossos). 
reconhecendo o acirramento da luta de classes e contrapondo-se, no plano da cultura, à burguesia e sua concepção de mundo.

Lina, a partir do final da década de 1950, terá um profundo envolvimento - teórico e projetual - no que ela própria chama de "esforço de libertação" do país do "colonialismo cultural". Participará da criação do movimento cultural na Bahia (por ela descrito como um "verdadeiro movimento de cultura de base", assumindo vivamente os valores de "uma cultura historicamente pobre"); se dedicará à reflexão sobre o significado e o potencial da arte popular, alimentando uma procura "antropológica e não estética" que faz da "incultura" (a produção popular e primitiva, não inibida pela "Cultura" e pela "instrução") a base de uma nova cultura e de uma nova civilização, contrapostas à cultura burguesa de gadgets e objetos de consumo.

Quanto a Artigas, embora no plano do discurso nacional-desenvolvimentista o arquiteto aparente ter a mesma perspectiva política de Motta ${ }^{3}$, ao projetar é obrigado a encarar as contradições desse discurso e resolvê-las em termos materiais - de modo que estas contradições se manifestam mais concretamente e se multiplicam. Artigas é capaz de ser negativo, e a negatividade que se manifesta em sua obra construída não raras vezes ultrapassa os seus escritos, expressando uma profunda "consciência da técnica".

Essa consciência - que se refere a uma técnica histórica e socialmente determinada - permite-lhe levar ao limite 4 a reflexão sobre as ligações arte e trabalho, arte e indústria, que estavam no centro das preocupações de Motta. A perspectiva sob a qual Artigas passa, nos anos 1960, a encarar a indústria da construção civil e o papel do arquiteto ("o arquiteto não é um profissional da indústria da construção, um apêndice de uma máquina constrangedora e terrível. Ao contrário, cabe-nos ajudar a dominar, a submeter a estrutura impositiva que transforma o homem em coisa, em vítima de sua própria criatura"5) terá inflexões em suas próprias obras, edifícios como o da FAUUSP, que a nosso ver é o melhor exemplo

3 Cf. nota 34 do Capítulo 4.

4 Esse limite da posição de Artigas, a nosso ver, é aquele de conseguir expor, concreta, poética e construtivamente, as contradições do próprio sistema capitalista, num plano mais geral, e aquelas da construção civil, da posição do arquiteto e do trabalhador, num plano mais específico. Depois desse limite, inevitavelmente, o que restaria era se render (ao mercado, ou ao "possível") ou se frustrar, se refugiar num idealismo extremado e no "direito à utopia" que Artigas melancolica e corajosamente reafirma na década de 1980.

5 ARTIGAS, V. "Aos formandos da FAUUSP", 1964. In: Caminhos da arquitetura. São Paulo, Fupam/ Cosacnaify, 1999, p. 156. 
da confiança de Artigas em que "a linguagem artística seja capaz de assimilar as contradições do contexto histórico, convertendo-as em problemas da forma poética" ${ }^{\prime \prime}$.

Para essas arquiteturas brutas de Lina e Artigas, que criticam poeticamente uma sociedade brutal, caberia a descrição que Lafetá faz do processo criativo de Mário de Andrade, no início da década de 1930:

Na destruição sistemática da linguagem (...) a forma se recompõe; no dilaceramento da consciência burguesa a forma se engaja; o projeto ideológico encontra seu caminho no interior do projeto estético (...) A linguagem, despida e violentada, revela seus artifícios e condena os contextos que a geraram. ${ }^{7}$

E é também Lafetá que nos aponta - bem ao fim de nosso trabalho - um sentido maior para o estudo da reconstrução histórica formulada por Flávio Motta e desenvolvida radicalmente pelos arquitetos, um sentido que não pode ser esquecido em tempos de barbárie: aquele da união necessária entre história e experimentação da linguagem, no qual a vanguarda "aparece como uma aventura, no entanto repleta de responsabilidades para o artista que a ela se lança" 8 .

6 KAMITA, J. M. Vilanova Artigas. São Paulo, Cosacnaify, 2000, p. 44.

7 LAFETÁ, J. L. "Ética e poética (Mário de Andrade, II)". In: 1930: a crítica e o modernismo. São Paulo, Duas Cidades/ Ed. 34, 2000, p. 209.

8 Ibidem, p. 215. 


\section{bibliografia}

\section{Bibliografia geral}

ALFIERI, Bruno. "Rapporto Brasile" [Introdução]. In: Revista Zodiac, no. 6, p. 57-58.

"João Vilanova Artigas: ricerca brutalista". In: Revista Zodiac, no 6, 1960, p. 97.

AMARAL, Aracy. Arte para Quê?: a preocupação social na arte brasileira, 1930-1970: subsídios para uma história social da arte no Brasil. São Paulo, Nobel, 2003.

AMARAL, Cláudio Silveira. "Rui Barbosa e John Ruskin: a política do ensino do desenho". Disponível em <www.vitruvius.com.br/revistas/read/arquitextos/10.121/3467 > Acesso em $25 / 08 / 2010$

ANAIS do IV Congresso de Arquitetos. São Paulo, 1954.

ANDRADE, Mário de. "Assim falou o papa do futurismo", 1925. In: LOPEZ, Telê Porto A.[org]. Mário de Andrade: entrevistas e depoimentos. São Paulo, TA Queiroz, 1983, p. 16-20.

"Arquitetura colonial", 1928. In: Arte em Revista no. 4, ago 1980, p. 12-14.

“O Aleijadinho e sua posição nacional”, 1928. In: Depoimentos 2. São Paulo, CEB/

GFAU, 1966, p. 14-26.

"Anteprojeto de Criação do Serviço do Patrimônio Artístico Nacional", 1936. In:

ANDRADE, M. Cartas de trabalho: correspondência com Rodrigo Mello Franco de Andrade (1936-1945). Rio de Janeiro, SPHAN/ Pró-memória, 1981, p. 39-54.

"Curso de filosofia e história da arte", 1938. In: Depoimentos 2. São Paulo, CEB/

GFAU, 1966, p. 30-39.1

“Esta Paulista Família", 1939. In: MOTTA, Flávio. "Textos informes - A família

artística paulista", Revista do IEB no. 10, 1971, p. 154-156.

"O movimento modernista", 1942. In: Aspectos da literatura brasileira.

Belo Horizonte, Itatiaia, 2002, p. 253-280.

"Brazil builds", 1943. In: Vv Aa. Depoimentos 1. São Paulo, CEB/ GFAU, 1960, p. 48.

ARANTES, Otilia. "Esquema de Lucio Costa". In: NOBRE, A. L. et al [orgs]. Um modo de ser moderno: Lucio Costa e a crítica contemporânea. São Paulo, Cosacnaify, 2004, p. 84-103.

1 Texto também conhecido como "O artista e o artesão". Optamos pelo uso do texto publicado em Depoimentos 2 pelo fato dessa edição, uma antologia de textos de Mário de Andrade, ter sido organizada por Flávio Motta (segundo AMARAL, A. "Como era Mário de Andrade?". In: Textos do Trópico de Capricórnio v. 1. São Paulo, Ed. 34, 2006, p. 36). 
ARANTES, Otilia e ARANTES, Paulo. Sentido da formação: três estudos sobre Antonio Candido, Gilda de Mello e Souza e Lúcio Costa. Rio de Janeiro, Paz e Terra, 1997.

ARAUJO, Ricardo Benzaquen de. "Nas asas da razão: ética e estética na obra de Lucio Costa". In: NOBRE, A. L. et al [orgs]. Um modo de ser moderno: Lucio Costa e a crítica contemporânea. São Paulo, Cosacnaify, 2004, p. 60-70.

ARGAN, Giulio Carlo. "Tradição e materiais antigos na arquitetura". In: Revista Habitat, no. 58, 1960, p. $3 .^{2}$

ARRUDA, Maria Arminda do Nascimento. Metrópole e cultura: São Paulo no meio do século XX. São Paulo, Edusc, 2001.

ARTIGAS, João Batista Vilanova. "A Bienal é contra os artistas brasileiros", 1951. In:

Caminhos da arquitetura. São Paulo, Cosacnaify, 2004, p. 30-34.

"Os caminhos da arquitetura moderna", 1952. In: ARTIGAS, J. B. V. Caminhos da arquitetura. São Paulo, Fupam/ Cosacnaify, 1999, p. 25-43.

"Considerações sobre arquitetura brasileira", 1954. In: ARTIGAS, J. B. V. Caminhos da arquitetura. São Paulo, Cosacnaify, 2004, p. 51-55.

"Rumos para o ensino da arquitetura", 1956. In: ARTIGAS, J. B. V. Caminhos da

arquitetura. São Paulo, Fupam/ Cosacnaify, 1999, p. 45-51.

"Arquitetura e cultura nacionais", 1959. In: ARTIGAS, J. B. V. Caminhos da

arquitetura. São Paulo, Fupam/ Cosacnaify, 1999, p. 113-121.

"Aos formandos da FAUUSP", 1964. In: ARTIGAS, J. B. V. Caminhos da arquitetura.

São Paulo, Fupam/ Cosacnaify, 1999, p. 153-156.

"O desenho", 1967. In: ARTIGAS, J. B. V. Caminhos da arquitetura. São Paulo, Fupam/ Cosacnaify, 1999, p. 69-84.

"A função social do arquiteto" - $3^{\text {a }}$ Argüição, 1984. In: ARTIGAS, J. B. V. Caminhos da arquitetura. São Paulo, Cosacnaify, 2004, p. 214-223.

BARDI, Lina bo. "Prefácio”. In: Revista Habitat, no. 1, 1950, p. 1.

“Bela criança". In: Revista Habitat no. 2, jan/mar 1951, p. 3. "arquitetura ou Arquitetura", 1958. In: RUBINO, Silvana [org.]. Lina por escrito:

textos escolhidos de Lina bo Bardi. São Paulo, Cosacnaify, 2009, p. 90-93.

“Museu de Arte Moderna da Bahia", 1959. In: BARDI, L. Lina bo Bardi. Instituto Lina bo e P.M. Bardi, 1996, p. 139.

2 Tese apresentada por Argan no Congresso Internacional Extraordinário de Críticos de Arte, em 1959. O texto é re-publicado, sem título e sem autoria, pela Revista Habitat (Fonte: CAPELLO, M. B. "Congresso Internacional de Críticos de Arte 1959: difusão nas revistas internacionais e nacionais especializadas", p. 8. Disponível em <www. docomomo.org.br/seminario\%208\%20pdfs/080.pdf >. Acesso em 25/08/2010). 
BARDI, Lina bo e GONÇALVES, Martim. "Bahia no Ibirapuera", 1959. In: BARDI, L. Lina bo Bardi. São Paulo, Instituto Lina bo e P.M. Bardi, 1996, p. 134-137.

"Técnica e arte", 1960. In: RUBINO, Silvana [org.]. Lina por escrito: textos escolhidos de Lina bo Bardi. São Paulo, Cosacnaify, 2009, p. 110-113.

"Cinco anos entre os brancos", 1967. In: BARDI, L. e FERRAZ, M. Lina bo Bardi. Instituto Lina bo e P.M. Bardi, 1996, p. 161-163.

“Na América do Sul, após Le Corbusier, o que está acontecendo?", 1967. Revista Mirante das Artes n. 1, jan/fev 1967, p. 10-14.

"Planejamento ambiental: 'desenho' no impasse", 1976. In: Revista Malasartes no 2, dez-fev 1976, p. 4.

"Tempos de grossura", 1977. In: BARDI, L. Lina bo Bardi. São Paulo, Instituto Lina bo e P.M. Bardi, 1996.

“Museu de Arte de São Paulo" [anotações pessoais]. In: BARDI, L. Lina bo Bardi. São Paulo, Instituto Lina bo e P.M. Bardi, 1996, p. 100-115.

BARDI, Pietro Maria. Pequena historia da arte: introdução ao estudo das artes plásticas. São Paulo, Melhoramentos, s.d. [déc. 50].

BAIEUX, Glória M. Debate da arquitetura brasileira nos anos 50. São Paulo, FAUUSP (Dissertação de Mestrado), 1991.

BRITO, Ronaldo. "Fluida modernidade". In: NOBRE, A. L. et al [orgs]. Um modo de ser moderno: Lucio Costa e a crítica contemporânea. São Paulo, Cosacnaify, 2004, p. 249-254.

BRUAND, Yves. Arquitetura contemporânea no Brasil. São Paulo, Perspectiva, 2008.

CANDIDO, Antonio. Formação da literatura brasileira. Belo Horizonte, Itatiaia, 1981. "Literatura e subdesenvolvimento", 1970. In: A educação pela noite e outros ensaios. São Paulo, Ática, 1989, p. 140-162.

"A Revolução de 30 e a cultura", 1980. In: Novos estudos CEBRAP, v.2, 4, abr. 1984, p. 27-36.

CARRILHO, Marcos. "Brazil builds: 55 anos da exposição". São Paulo, 1998. Disponível em <www.piniweb.com.br/construcao/noticias/brazil-builds---55-anos-da-exposicao-84648-1.asp>. Acesso em 5/5/2010.

COSTA, Juliana Braga. "Rapporto Brasile: arquitetura brasileira na revista Zodiac, 1960". Disponível em <www.docomomo.org.br/seminario\%208\%20pdfs/169.pdf> . Acesso em $17 / 08 / 2010$.

COSTA, Lucio. "O Aleijadinho e a arquitetura tradicional", 1929. In: XAVIER, Alberto [org]. Lucio Costa: sobre arquitetura. Porto Alegre, UniRitter, 2007, p. 12-16.

"Razões da nova arquitetura", 1933-35. In: XAVIER, Alberto [org]. Lucio Costa: sobre arquitetura. Porto Alegre, UniRitter, 2007, p. 17-41. 
COSTA, Lucio. "Documentação necessária”, 1937. In: XAVIER, Alberto [org]. Lucio Costa: sobre arquitetura. Porto Alegre, UniRitter, 2007, p. 86-94.

"Notas sobre a evolução do mobiliário luso-brasileiro", 1939. In: XAVIER, Alberto

[org]. Lucio Costa: sobre arquitetura. Porto Alegre, UniRitter, 2007, p. 97-110.

"Introdução a um relatório", 1948. In: COSTA, L. Lucio Costa: registro de uma

vivência. São Paulo, Empresa das Artes, 1995, p. 455-456.

"Depoimento de um arquiteto carioca", 1951. In: XAVIER, Alberto [org]. Lucio

Costa: sobre arquitetura. Porto Alegre, UniRitter, 2007, p. 169-201. ${ }^{3}$

"Considerações sobre arte contemporânea", 1952. In: XAVIER, Alberto [org]. Lucio

Costa: sobre arquitetura. Porto Alegre, UniRitter, 2007, p. 202-229.

"J FL - Lelé", 1985. In: COSTA, L. Lucio Costa: registro de uma vivência. São Paulo,

Empresa das Artes, 1995, p. 434.

FAUSTO, Boris. História concisa do Brasil. São Paulo, Edusp, 2006.

GIANNECCHINI, Ana Clara. Técnica e estética no concreto armado: um estudo sobre os edifícios do MASP e da FAUUSP. São Paulo, FAUSP (Dissertação de mestrado), 2009.

KAMITA, João Masao. Vilanova Artigas. São Paulo, Cosacnaify, 2000.

KOPP, Anatole. Quando o moderno não era estilo e sim uma causa. São Paulo, Nobel/Edusp, 1990.

LAFETÁ, João Luiz. "Ética e poética (Mário de Andrade, II)". In: 1930: a crítica e o modernismo. São Paulo, Duas Cidades/ Ed. 34, 2000, p. 185-224.

LEON, Ethel. "O Instituto de Arte Contemporânea do Museu de Arte de São Paulo". In: Revista Desígnio, no. 5. São Paulo, 2006, p. 147-162.

LOFEGO, Silvio. "A construção da memória na publicidade do IV Centenário da Cidade de São Paulo". In: Revista Patrimônio e memória no.2. São Paulo, Unesp/ FCLAs/ CEDAP, 2006, p. 32-51. LOURENÇO, Maria Cecília França. Operários da modernidade. São Paulo, Edusp/ Hucitec, 1994. MACHADO, Lourival Gomes. Retrato da arte moderna do Brasil. São Paulo, Depto. de Cultura, 1947.

MANTEGA, Guido. A Economia Política Brasileira. São Paulo/Petrópolis: Polis/Vozes, 1985.

MARTINS, Carlos Ferreira. "A constituição da trama narrativa na historiografia da arquitetura moderna brasileira". In: Revista Pós no. especial. São Paulo, FAUUSP, 1994, p. 91-95. "Lucio Costa e Le Corbusier: afinidades eletivas". In: NOBRE, A. L. et al [orgs]. Um modo de ser moderno: Lucio Costa e a crítica contemporânea. São Paulo, Cosacnaify, 2004, p. 71-83.

MARTINS, Luis. "A arte paulista nos séculos XIX e XX". In: O Estado de São Paulo, Edição do IV Centenário, 25/01/1954, p. 137-139.

3 Texto também conhecido como "Muita construção, alguma arquitetura e um milagre". 
MIRANDA, Clara Luiza. A crítica de arquitetura nos anos 50, a expressão plástica e a síntese das artes. São Carlos, EESC-USP (Dissertação de Mestrado), 1998.

MOTTA, Renata. MASP em exposição: mostras periódicas na Sete de abril. São Paulo, São Paulo, FAUUSP (Dissertação de Mestrado), 2003.

NIEMEYER, Oscar. “Depoimento”, 1958. In: Revista Zodiac, no. 6, 1960, p. 131-135.

NOBRE, Ana Luiza. "Fontes e colunas: em vista do patrimônio de Lucio Costa". In: NOBRE, A.

L. et al [orgs]. Um modo de ser moderno: Lucio Costa e a crítica contemporânea. São Paulo, Cosacnaify, 2004, p. 121-131.

PEDROSA, Mário. "A arquitetura moderna no Brasil", 1953. In: AMARAL, A. [org]. Dos murais de Portinari aos espaços de Brasília. São Paulo, Perspectiva, 1981, p. 255-264.

"Entre a Semana e as Bienais", 1970. In: PEDROSA, M. e AMARAL, A. [org]. Mundo, homem, arte em crise. São Paulo, Perspectiva, 1975, p. 269-279.

PINHEIRO, Maria Lúcia Bressan. "Lúcio Costa e a Escola Nacional de Belas Artes". Disponível em <www.docomomo.org.br/seminario\%206\%20pdfs/Maria\%20Lucia\%20Bressan\%20Pinheiro. pdf>. Acesso em 22/04/2010.

PEVSNER, Nikolaus. Pioneiros do desenho moderno. Lisboa, Ulissea, 1962. Origens da arquitetura moderna e do design. São Paulo, Martins Fontes, 1981.

PRADO, J. F. de Almeida. "Arquitetos em São Paulo em 1880". In: Revista Habitat, no. 3, p. 50-53.

PRADO JR, Caio. A formação do Brasil contemporâneo. São Paulo, Brasiliense, 2008.

RECAMAN, Luiz Antonio. Por uma arquitetura, brasileira. São Paulo, FFLCH (Dissertação de mestrado), 1996.

REIS FILHO, Nestor Goulart. Quadro da arquitetura no Brasil. São Paulo, Perspectiva, 2000.

RUBINO, Silvana. "O mapa do Brasil passado". In: Revista do Patrimônio Histórico e Artístico Nacional, n. 24, 1996, p. 97-105.

SAIA, Luís. "A fase heróica da arquitetura contemporânea brasileira já foi esgotada há alguns anos", 1954. In: Arte em Revista, no. 4, ago 1980, p. 51-52

"Arquitetura paulista", 1959. In: XAVIER, A. [org]. Depoimento de uma geração: arquitetura moderna brasileira. São Paulo, Cosacnaify, 2003.

SCHWARZ, Roberto. "Cultura e política, 1964-1969". In: O pai de família e outros estudos. Rio de Janeiro, Paz e Terra, 1978, p. 61-92.

"Os sete fôlegos de um livro". In: Seqüências brasileiras: ensaios. São Paulo, Cia das Letras, 1999, p. 46-58.

"Sobre a Formação da Literatura Brasileira". In: Seqüências brasileiras: ensaios. São Paulo, Cia das Letras, 1999, p. 17-23.

STUCHI, Fabiana. Revista Habitat: um olhar moderno sobre os anos 50 em São Paulo. São Paulo, FAUUSP (Dissertação de Mestrado), 2006. 
TAVEIRA, Alberto. “Fogos de artifício à luz do dia: a arquitetura de Antonio Virzi no Rio de Janeiro". In: Revista Cidade Nova, no 1, 2007, p. 163-173.

THOMAZ, Dalva. Um olhar sobre Vilanova Artigas e sua contribuição à arquitetura brasileira. São Paulo, FAUUSP (Dissertação de Mestrado), 1997. Artigas: a liberdade na inversão do olhar. São Paulo, FAUUSP (Tese de doutorado), 2005.

Vv Aa. Arquitetura e desenvolvimento nacional. São Paulo, Pini/IAB, 1979.

Vv. Aa. "Depoimentos: Flávio Motta". Revista Caramelo, no. 6, p. 41-53, São Paulo, GFAU, 1993.

VENANCIO FILHO, Paulo. "Considerações sobre Lucio Costa". In: NOBRE, A. L. et al [orgs]. Um modo de ser moderno: Lucio Costa e a crítica contemporânea. São Paulo, Cosacnaify, 2004, p. 255-258.

WISNIK, Guilherme. "A arquitetura lendo a cultura". In: NOBRE, A. L. et al [orgs]. Um modo de ser moderno: Lucio Costa e a crítica contemporânea. São Paulo, Cosacnaify, 2004, p.32-40.

XAVIER, Alberto [org]. Lucio Costa: sobre arquitetura. Porto Alegre, UniRitter, 2007.

ZANINI, Walter. "Arte e história da arte". In: Revista Estudos Avançados 8(22), 1994, p. 487-489.

ZEVI, Bruno. "Inchiesta su Brasilia". In: Revista L'Architettura Cronache e Storia , no. 9, jan. 1960 , p. 608-619.

\section{Textos de Flávio Motta ${ }^{4}$}

MOTTA, Flávio Lichtenfels. "Um museu do estilo floreal em São Paulo". In: Revista Habitat, no. 1, 1950, p. 73. (*) "Diana addormentata", 1952. Revista Habitat, abr/jun 1952, p. 55-57. "Saul Steinberg no Brasil",1952. Revista Habitat, v. 6, out/dez 1952, p. 72-73. . "São Paulo e o art nouveau". In: Revista Habitat, no. 10, 1953, p. 3-18. (*) "A época do SPAM", 1953. Revista Habitat, v. 11, jun 1953, p. 49-60. "Floreal". In: Revista Habitat 12, 1953, p. 58-61. (*) "Verde em São Paulo", 1952. Revista Habitat, v. 6, jan/mar 1952, p. 72-73. e BORBA, Rosy de. (redação). Boletim "O Museu de Arte de São Paulo", no. 1-4. São Paulo, MASP, 1954. "400 anos de pré-história das artes", 1954. In: Vv Aa. IV Centenário da Cidade de São Paulo. São Paulo, Gráfica Municipal, 1954. (*) Contribuição ao estudo do art nouveau no Brasil. São Paulo, FAUUSP (Cátedra),

1957. $(*)$

4 Os textos estão organizados em ordem cronológica. Aqueles mais diretamente utilizados no presente trabalho estão marcados com (*). 
MOTTA, Flávio Lichtenfels. "Introdução ao Brasil", 1960. Tradução J. B. Costa. In: COSTA, J.

B. Ver não é só ver: dois estudos a partir de Flávio Motta. São Paulo, FAUUSP (Dissertação de Mestrado), 2010, p. 201-208. (*)

"Introduzione al Brasile", 1960. In: Revista Zodiac, no. 6, 1960, p. 61-67. (*)

"Francisco Brennand", 1961 (Catálogo Arte Pernambucana I: Brennand). Recife, SENEC-DECA, 1961.

“Exposição Victor Brecheret: Apresentação e Texto - roteiro para exposição", 1962.

São Paulo, FAUUSP(datilografado), 1962.

"Apontamentos de história da arte: o sorriso da Gioconda", 1963. São Paulo,

FAUUSP, 1963.

"Apontamentos de história da arte: milagre da fonte", 1963. São Paulo, FAUUSP,

1963.

"João Vilanova Artigas e a escola de São Paulo", 1965. Revista Módulo (no. especial Vilanova Artigas), 1985, p. 23.

"Art nouveau, um estilo entre a flor e a máquina", 1965. São Paulo, Cadernos

Brasileiros, v. 28, n. 2, p. 54-63, mar/abr. 1965. (*)

. Arte cinética e pop art, 1967. São Paulo, FAUUSP, 1969.

"Desenho e emancipação", 1967. In: ANDRADE, M., ARTIGAS e V. MOTTA, F. Sobre

desenho. São Paulo, GFAU, 1975.

“Paulo Mendes da Rocha", 1967. Revista Acrópole, São Paulo, no. 343, p. 17-18, set.

$1967^{5}$.

. "Convênio Internacional de artistas, críticos e estudiosos de arte (Rimini e Verucchio,

Itália)". São Paulo, Separata do no. 67 da Revista de História, 1967.

"Visconti e o início do século XX", 1969. In: PONTUAL, Roberto. Dicionário das artes plásticas no Brasil. RJ, Civilização Brasileira, 1969.

. "Sem título",1969 (Abertura do catálogo da exposição "Paço das Artes"). São Paulo, Fundo estadual de cultura, 1969.

"A arte e a vida urbana no Brasil", 1970. In: MOTTA, F. Textos Informes. São Paulo,

FAUUSP, 1973, p.1-36.

“O gosto", 1970. In: MOTTA, F. Textos Informes. São Paulo, FAUUSP, 1973, p.5-7.

. "A casa",1970. In: MOTTA, F. Textos Informes. São Paulo, FAUUSP, 1973, p.8-9.

"As esculturas de plástico de Mário Cravo Junior", 1970. In: MOTTA, F. Textos

Informes. São Paulo, FAUUSP, 1973, p.10-15.

“O olho", 1970. In: MOTTA, F. Textos Informes. São Paulo, FAUUSP, 1973, p.16.

"Trabalho e linguagem", 1970. In: MOTTA, F. Textos Informes. São Paulo, FAUUSP,

1973, p.17-18.

5 Também publicado em MOTTA, F. Textos Informes. São Paulo, FAUUSP, 1973, p.19-23.

6 Também publicado em BARDI, Lina bo. Tempos de grossura: o design no impasse. São Paulo, Instituto

Lina Bo e P.M. Bardi, 1994, p. 57-59. 
MOTTA, Flávio Lichtenfels. "Desígnios industriais e arquitetura",1970. In MOTTA, F. Textos Informes. São Paulo, FAUUSP, 1973, p.24-26.

"Arquitetura brasileira para a Expo'70", (s.d). Revista Acrópole, São Paulo, no. 372, p. 25-26, abr $1970^{7}$.

"David e Golias", 1970. In: MOTTA, F. Textos Informes. São Paulo, FAUUSP, 1973, p.34-

39.

"A velha senhora indigna", 1970. In: MOTTA, F. Textos Informes. São Paulo, FAUUSP, 1973, p. 40.

“Nelson Leirner", 1970. In: MOTTA, F. Textos Informes. São Paulo, FAUUSP, 1973, p. 41.

"A família artística paulistana", 1971.In: Revista do Instituto de Estudos Brasileiros, no. 10,1971 , p. $137-154$.

MOTTA, F. L. "Sérgio Ferro", 1971. In: MOTTA, F. Textos Informes. São Paulo, FAUUSP, 1973, p. 55-57.

"Antonio Henrique Amaral", 1971. In: Bananas [Catálogo de exposição]. Rio de Janeiro, Galeria Bonino, 1971.

"Trabalho de um pintor: Portinari", 1972. São Paulo, Separata da Revista de História no. $90,1972$.

"Carlos Leão", 1972. In: MOTTA, F. Textos Informes. São Paulo, FAUUSP, 1973, p. 53-

54.

"Maria Bonomi", 1972. In MOTTA, F. Textos Informes. São Paulo, FAUUSP, 1973, p.

$42-44$.

"Gravuras de Renina", 1972. In: MOTTA, F. Textos Informes. São Paulo, FAUUSP, 1973, p. 45-52.

"A jóia como projeto urbano", 1973.In: MOTTA, F. Textos Informes. São Paulo, FAUUSP, 1973, p. 58-60.

"Cismamentos e anotações", 1973. In: MOTTA, F. Textos Informes. São Paulo, FAUUSP, 1973, p. 61-63.

"Também pintar", 1973. In: MOTTA, F. Textos Informes. São Paulo, FAUUSP, 1973, p. 64-65.

"Arte pobre: gato encaixado", 1973. In: MOTTA, F. Textos Informes. São Paulo, FAUUSP, 1973, p. 66-67.

"Nelson Leirner - a rebelião dos animais: uma série de desenhos", 1974 (Catálogo da exposição). São Paulo/ Texas, University Art Museum (University of Texas, Austin) / Brazilian American Cultural Institute/ Masp, 1974.

. "Subsídios para um relatório sobre ensino de arquitetura / UIA-Unesco - No. 2". São

Paulo, FAUUSP (datilografado), 1974.

. "Superfícies habitáveis: memorial 1", 1974. Suplemento Literário do Estado de São

Paulo, no. 876, 12/05/1974, p. 5.

7 Também publicado em MOTTA, F. Textos Informes. São Paulo, FAUUSP, 1973, p.28-33. 
MOTTA, Flávio Lichtenfels. "Superfícies habitáveis: memorial 3", 1976. Revista Módulo, v. 42, mar/mai 1976, p. 48.

"Textos informes: emigração universitária", 1977. São Paulo, s.c.p., 1977.

"A restauração", 1975. In: PRADO, M. e MACHADO, L. G. Exposição Vila Penteado. São Paulo, FAUUSP/ Secretaria de Cultura, 1976.

"Roberto Burle Marx e a nova visão da paisagem", 1977. Caderno Geografia e Planejamento no. 26. São Paulo, Instituto de Geografia da USP, $1977 .{ }^{8}$

" "Pequeno Álbum" (sete gravuras em metal de Aldemir Martins, texto de Flávio Mota). São Paulo, João Pereira e Livraria Klaxon, 1980.

. "Art nouveau, modernismo, ecletismo e industrialismo", 1983. In: ZANINI, W. História geral da arte no Brasil v. 1. São Paulo, Moreira Salles/ Djalma Guimarães, 1983.

. "Rubens Matuck", 1987. In: Catálogo de exposição. São Paulo, Galeria de Arte Sãp Paulo, 1987.

8 Também publicado em livro: MOTTA, F. L. Roberto Burle Marx e a nova visão da paisagem. São Paulo, Nobel, 1984. 



\section{anexos \\ cartas de flávio motta a pietro maria bardi ${ }^{1}$}

Publicamos aqui duas cartas de Motta a Pietro Maria Bardi, que se encontram, datilografadas, no Arquivo Histórico da biblioteca do MASP (Pasta "1956 Flavio Motta - Caixa 2 Pasta 8", Memorando 9). Esses documentos, além de esclarecer os métodos e fontes utilizados por Motta na elaboração de seus estudos sobre o art nouveau, jogam luz sobre as relações entre o autor e Bardi, a quem vemos respeitosamente chamado de "professor". Bardi, de fato, foi uma espécie de orientador de Motta nos anos em que este trabalhou no MASP, e sua influência parece deixar marcas no trabalho posterior do "discípulo".

\section{[Documento 23]}

Professor:

Recebi ontem os anuários "Studio". Ótimos. Muito obrigado. O material que estou recolhendo no Rio é da melhor qualidade. Imagine o senhor que verifiquei que o Visconti e o Lucílio de Albuquerque estudam com o Grasset na Academia Julien. A D. Georgina encontrou os apontamentos das lições do Grasset, feitos pelo Lucílio. São aulas completas, com desenhos e teoria "art nouveau". Encontrei também nomes e obras dos artistas "liberty" no Rio e uma série completas (sic) de artigos, entre 1900/1903, comentando a arquitetura da época, com longas referencias às teorias de Victor Horta. O senhor se lembra daquela casa curiosa da av. Atlântica. Há tempos foi reformada. Antigamente era muito mais "art nouveau" e o arquiteto era um espanhol, chamado Virzi que depois, junto com o Helius Seelinger, fez o pavilhão do Brasil num (sic) das exposições de Turim (talvez a de 1907). Gostaria de verificar se esse espanhol teve alguma ligação com o grupo de Gaudi. O Helius Seelinger está vivo. È um tipo bastante lúcido. Foi aluno do Stuck e participou do movimento renovador, no fim do século, em Munich. Foi também ilustrador do Jungden e o Simplissimus. Encontrei, na Escola de Belas Artes o livro do Lahor - "Histoire du art nouveau", vários álbuns do Grasset, farto material sobre o emprego do ferro na arquitetura, coleções inteiras da re-

1 Digitadas pela autora em 13/05/2009. 
vista "Natura ed art", "L'art decoratif"; um numero especial da "Jungend", um álbum de abertura, em 1907, da av. rio Branco, com desenhos e fotos de todos os edifícios, etc. Tenho ótimas referencias sobre os estucadores (quase todos portugueses) e dos serralheiros.

Registrei "art nouveau" no Ceará, no Paraná, em Minas, etc. Saiu um livro do Brito Broca sobre a vida literária no Brasil, por volta de 1900. Estou com uma enorme bibliografia. Vou fichando tudo. Meu plano, em resumo, é acenturar (sic), primeiro, o caráter internacional, cosmopolita, do "art nouveau", estudando-o primeiro na Europa, para depois me demorar no aspecto nacional.

Um amigo meu que foi agora para a Inglaterra vai fazer uma pesquisa na "liberty" e no "Mappin Webb". Quero ver se obtenho alguma coisa da terra do Munch, da Áustria, dos Estados Unidos e da Rússia. Vi umas fotos de "art nouveau", na Rússia, formidáveis. O senhor que já teve lá, lembra-se de alguma coisa? Aquele substrato bizantino deve ter favorecido o desenvolvimento na URSS. Estou curioso para verificar esse fato. Por outro lado, gostaria de obter fotos novas do metrô de Paris, alguma coisa de Milão, Barcelona, Lisboa, Porto, talvez Nápoles, Genova, Monte Carlo, etc.

Vou assim recolhendo o máximo de material, estudando-o, classificando-o e depois com vagar, com as fichas e fotos na mão, vou desenvolvendo, ligando as observações, para atingir a medida mais real possível do problema, destacando-o do fundo histórico em que viveu.

É um trabalho que está me apaixonando.

Estou agora bem de saúde e com ânimo para trabalhar.

Ontem fui procurado pelo Xavier. Quer saber se transferimos ou ano, definitivamente, as Escolas para a Fundação. Sugeri que a própria Fundação fizesse uma consulta direta, por escrito, ao dr. Assis. Ele tirou o corpo. Pedi tempo para estudar uma fórmula que não venha prejudicar os futuros entendimentos. Estou pensando no assunto. Caso eles não façam acordo, com as nossas escolas, farão outra escola. Naturalmente uma escola de Belas Artes ou um novo Ciccillo.

Isto é o que menos me preocupa. Quando existe uma coisa séria, estou certo, não se deve ocupar das porcarias. A questão é saber se, no plano das escolas, poderemos fazer, mesmo, uma coisa séria. Quais as condições que a Associação Museu 
de Arte oferece? Para seu governo devo dizer que, financeiramente, as Escolas estão em dia. Devolvemos à Fundação, inclusive, aqueles primeiros auxílios de 20.000 por mês. Cumprimos, à risca, tanto o Convenio da Prefeitura como com a Fundação.

O Segall quase morreu. Teve um enfarto. Está de cama, mais restabelecido e com balão de oxigênio.

Esse pessoal do Bazin é de amargar. Imagine os senhor que os livros estão sendo vendidos nas livrarias. Os livreiros importam, em geral, através da Hachette, de Paris. Devo tomar uma providência de ordem legal com essa gente e o senhor deve me dar alguns conselhos.

Recomendações a d. Lina. Agora o dr. Assis me chamou. Parece que há encrencas com a Villa.

Abraços,

Flávio

26/9/1956

\section{[Documento 22]}

Professor:

Eis algumas coisas que preciso de suas luzes para ver melhor o problema do "art nouveau":

1. A exposição "Vienna Secession"

2. O prof. Mario Segantini que foi aluno do escultor Gurschner, conforme consta de um numero da revista "Studio" - 1901 que encontrei na casa dos Rossi.

3. Sperling - firma de Leipzig onde trabalhou um dos maiores encadernadores do "art n." - Paul Kersten. Num longo artigo sobre encadernações "a.n." vejo, também na revista "Studio" (1901) referências a um certo estilo "marocco workers" que os franceses passam aos alemães, mas cuja origem está nos italianos do século XVI e que se caracteriza pela repetição de elementos decorativos simples. Isto, a meu ver, é importante, porque este Paul Kersten vai se aproximar, nas artes gráficas, à tendência simplificadora de um Van de Velde. O artigo faz referencias a Veneza.

4. Exposição Internacional de Dresde (1901)

5. Viogt \& Collin - de Berlim

Escola de Durlach e Graf de Altenbourg

Otto Horn 
Os professores Wilhelm Patizel

Alfredo Kullmann

Os franceses: Rubans

Marius Michels

Charles Meuniers

Miss (?) E. McColl

6. Lahor, Jean. "L'art nouveau, son histoire" - L'art nouveau étranger à l'Exposition. L'art nouveau au point de vue social" - livro editado em Paris, 1901, por Lamerre.

7. "Art Nouveau Bing" - loja à Rue de Provence, 22, onde eram vendidas as peças de Georges de feure.

8. Roger Marx - "La Décoration et les Industries d'art à l'Exposition Universelle de 1900" - Delagrave, éditeur, 15, rue Soufflot. Paris, 1901. Do mesmo autor - "Les Medailleurs modernes en France et à L étrnager" Delagrave edit.

9. Tenho aqui vários números da revista "The Studio" - 1889-1901 e também o "L'art décoratif" - 1901-1902, revistas compradas pelos nossos artistas "art nouveau". Encontrei excelente artigo sobre V. Horta, fartamente ilustrado.

10. Não será o figurino de modas uma criação da época? Qual é a origem do figurino?

O item 5 é de menor importância. É mais uma curiosidade para confirmar a influência dos franceses sobre os alemães.

11. O senhor tinha na sua biblioteca um livro sobre "1900". Ainda tem?

12. Obrigado por tudo. Um grande abraço. Desculpe a minha letra. Escreverei logo. Estou compilando estes dados enquanto espero o carro para acompanhar d. Lina ao aeroporto.

Flávio 